\title{
Classical liberalism and international relations theory : Hume, Smith, Mises, Hayek and International Society
}

Citation for published version (APA):

van de Haar, E. R. (2008). Classical liberalism and international relations theory : Hume, Smith, Mises, Hayek and International Society. [Doctoral Thesis, Maastricht University]. Maastricht University. https://doi.org/10.26481/dis.20080605eh

Document status and date:

Published: 01/01/2008

DOI:

10.26481/dis.20080605eh

Document Version:

Publisher's PDF, also known as Version of record

\section{Please check the document version of this publication:}

- A submitted manuscript is the version of the article upon submission and before peer-review. There can be important differences between the submitted version and the official published version of record. People interested in the research are advised to contact the author for the final version of the publication, or visit the DOI to the publisher's website.

- The final author version and the galley proof are versions of the publication after peer review.

- The final published version features the final layout of the paper including the volume, issue and page numbers.

Link to publication

\footnotetext{
General rights rights.

- You may freely distribute the URL identifying the publication in the public portal. please follow below link for the End User Agreement:

www.umlib.nl/taverne-license

Take down policy

If you believe that this document breaches copyright please contact us at:

repository@maastrichtuniversity.nl

providing details and we will investigate your claim.
}

Copyright and moral rights for the publications made accessible in the public portal are retained by the authors and/or other copyright owners and it is a condition of accessing publications that users recognise and abide by the legal requirements associated with these

- Users may download and print one copy of any publication from the public portal for the purpose of private study or research.

- You may not further distribute the material or use it for any profit-making activity or commercial gain

If the publication is distributed under the terms of Article $25 \mathrm{fa}$ of the Dutch Copyright Act, indicated by the "Taverne" license above, 


\section{Classical Liberalism and \\ International Relations Theory}

Hume, Smith, Mises, Hayek and International Society 
Design and Printed by Central Books, Quezon City, Metro Manila, Philippines

Copyright (C) E.R. van de Haar 2008

All rights reserved. No part of this publication may be reproduced, stored in a retrieval system, or transmitted, in any form or by any means, without the prior written permission of the author. 


\section{Classical Liberalism and \\ International Relations Theory}

Hume, Smith, Mises, Hayek and International Society

\section{PROEFSCHRIFT}

ter verkrijging van de graad van doctor aan de Universiteit Maastricht, op gezag van de Rector Magnificus, Prof. Mr G.P.M.F. Mols volgens het besluit van het College van Decanen, in het openbaar te verdedigen op 5 juni 2008 om 12.00 uur

door

Edwin René van de Haar 
Promotor:

Professor mr N.H.M. Roos

Copromotor:

Dr F. van Dun (Universiteit Gent)

Beoordelingscommissie:

Professor dr J.C. Hage (voorzitter)

Professor dr P.B. Cliteur (Universiteit Leiden)

Dr F. Grünfeld

Professor dr N.J. Rengger (University of St. Andrews)

Dr M. Stout

This research was partially funded by the 'Partners Study Fund' of the Netherlands Ministry of Foreign Affairs; The Institute for Humane Studies, Arlington, Virginia, USA; and The Ludwig von Mises Institute, Auburn, Alabama, USA.

These organisations do not bear any responsibility for the views expressed in this thesis. 


\section{Acknowledgments}

It is with great pleasure that I thank the many people who have helped me during the research and writing of this thesis. Most gratitude goes to my wife Anita, for her constant enthusiastic support and patience, especially during the first two and a half years when academic work was restricted to the evenings and weekends. Also I must thank our beloved son Tim. As a baby he slept enough to enable me to get some work done at night and on 'daddy day', while he provided us with laughter and happiness throughout the years this thesis took before completion. I would like to thank my mother for helping out whenever needed.

At Leiden University, I would like to thank Professor Albert Kersten for stimulating his students, this one in particular, to pursue PhDs. Professor Andreas Kinneging provided valuable feedback on the initial research plan.

Dr Razeen Sally of the London School of Economics and Political Science has been a strong and friendly support for all of my academic endeavours, from the very early stages of this project onwards. His own work on classical liberalism and international economic relations provided an important intellectual inspiration for this dissertation, which I acknowledge in gratitude. I also thank Professor Christopher Hill, my tutor at the LSE, now Director of the Centre of International Studies at Cambridge University, for our stimulating talks over the years.

Professor Aad van Mourik brought me into contact with my supervisors at Maastricht University, which was a vitally important step for which I am indebted. Professor Nico Roos and Dr Frank van Dun were the best supervisors any $\mathrm{PhD}$ student could hope for. They were critical yet constructive in their comments, worked incredibly fast and both of them were always available for additional advice or help when I needed it. Above all, they are very kind and genial men to spend time with!

This is also the place to thank the members of the review committee, Professor Nick Rengger, Professor Paul Cliteur, Dr Mark Stout, Professor Jaap Hage and Dr Fred Grünfeld for agreeing to serve on the committee. 
Dr Erik Knippenberg of the Law Faculty of Maastricht University has also been of great assistance.

Over the past years I have been fortunate enough to enjoy the continual support of the Institute for Humane Studies at George Mason University in Arlington, Virginia, USA. In particular, I would like to express my deep gratitude to Dr Nigel Ashford for his interest, enthusiasm and criticism. Many thanks are also due to Elaine Hawley, Chris Nelson, my fellow Summer Graduate Research Fellows, Dr Colin Dueck, Henrik Rasmussen, Magnus Nordenman and other people in the IHS network for their comments and pleasant discussions.

I am much obliged to the Ludwig von Mises Institute in Auburn, Alabama, USA; in particular Dr Mark Thornton for his advice and Pat Barnett, who did everything possible to make my research visit productive and stimulating. Mrs Bettina Greaves was kind enough to allow me to use her unpublished interviews with Mises' wife and friends, while Professor Jeffrey Herbener granted permission to use some of Mises' correspondence which is part of the Ludwig von Mises Archive at Grove City College.

The Netherlands Ministry of Foreign Affairs has been a source of financial support through the 'Partners Study Fund' of the Spouses and Children Bureau. I would like to thank the former Head, Marisa Witte, for opening the fund to PhD students and Monica Vermeulen and Wilma de Haan for their efficient assistance ever since. The staff at the Ministry's Library and Information Service (DDI) were also great; they never tired of lending me books and sending them to Manila!

Carol Leadenham and her colleagues at the Hoover Institution Archives at Stanford University were very friendly and helpful during my research of the Hayek Papers. Permission to quote from F.A. Hayek's correspondence and papers was granted by the estate of F.A. Hayek, for which I thank the kind co-operation of the editor of the collected works of F.A. Hayek, Professor Bruce Caldwell of the University of North Carolina.

Cambridge University Press and the British International Studies Association are the copyright holders of my article entitled 'David Hume and International Political Theory: a Reappraisal', published in Review of International Studies, volume 34, number 2, April 2008, which is partially reprinted with permission in Chapter Three. 
Janet Picken was a very efficient and meticulous copy editor, I am grateful for her enthusiastic willingness to help me out.

I close by thanking my family, friends and all those who have shown interest in the progress of the thesis over the past four and a half years. I would particularly like to acknowledge the support of Hans van den Broek and Christward Dieterman, especially during the very last stages of what have been exciting and stimulating years of academic adventure.

Edwin van de Haar

Manila, Spring 2008 



\section{Contents}

Acknowledgments $\quad$ V

Glossary $\quad$ xi

1 Introduction 1

2 What is classical liberalism? 34

3 David Hume and International Society 58

4 Adam Smith, War and Commerce 80

5 Ludwig von Mises, Capitalism and Peace 105

6 Friedrich Hayek, International Order 140 and Federalism

7 Liberalism and International Relations Theory 172

8 Conclusions and Ways Forward 212

$\begin{array}{ll}\text { Bibliography } & 220\end{array}$

Index $\quad 262$

$\begin{array}{ll}\text { Dutch summary } & 270\end{array}$

$\begin{array}{ll}\text { Curriculum Vitae } & 282\end{array}$ 



\section{Glossary}

\section{Works of David Hume:}

$\mathrm{E}=$ Essays

$\mathrm{EHU}=$ Enquiry concerning Human Understanding

$\mathrm{EPM}=$ Enquiry concerning the Principles of Morals

$\mathrm{H}(\mathrm{n})=$ The History of England (by volume)

$\mathrm{L}(\mathrm{n}) \quad=\quad$ Letters of David Hume (by number)

$\mathrm{THN}=\quad$ Treatise of Human Nature

\section{Works of Adam Smith:}

$\mathrm{C}=$ Correspondence

LJA $=$ Lectures on Jurisprudence (version A, 1762-1763)

$\mathrm{LJB}=$ Lectures on Jurisprudence (version B, 1766)

TMS = Theory of Moral Sentiments

WN = The Wealth of Nations

Works of Ludwig von Mises:

$\mathrm{EF}=$ Economic Freedom and Interventionism

$\mathrm{HA}=$ Human Action

$\mathrm{L} \quad=\quad$ Liberalism

MMM = Money, Method and the Market Process

NSE = Nation, State and Economy

$\mathrm{OG}=$ Omnipotent Government

$\mathrm{S}=$ Socialism

Works of Friedrich Hayek:

$\mathrm{CL}=$ The Constitution of Liberty

$\mathrm{IEO}=$ Individualism and Economic Order

$\operatorname{LLL}(\mathrm{n})=\quad$ Law, Legislation and Liberty (volume numbers in Roman numerical)

RS $=$ The Road to Serfdom

$\mathrm{SW}=$ Socialism and War 
Other abbreviations:

EEC $=$ European Economic Communities

$\mathrm{EU}=$ European Union

GATT $=\quad$ General Agreement on Tariffs and Trade

$\mathrm{IMF}=$ International Monetary Fund

IR $=$ International Relations

IPT = International Political Theory

LSE $=$ London School of Economics and Political Science

MPS $=$ Mont Pelerin Society

NATO $=\quad$ North Atlantic Treaty Organisation

$\mathrm{UN}=\quad$ United Nations

US $(\mathrm{A})=\quad$ United States (of America)

$\mathrm{WTO}=$ World Trade Organisation 


\section{1 \\ Introduction}

Liberalism in international relations (IR) ${ }^{1}$ theory is presented in an incomplete, often erroneous way. This book will challenge and supplement that practice. It is especially puzzling that all liberals in international relations theory appear to start from an identical philosophical premise and more or less favour identical aims and solutions to reach peace in world politics. While there are different forms of liberalism in international relations and it is no exaggeration to claim that liberalism has been one of the most prominent strands of IR theory, there is still a particular one-sidedness to it. Liberalism is mainly presented as emphasising a state-led construction of international order, based on an optimistic view on human nature and a firm belief in the possibility to literally create peace (see for an overview Zacher and Matthew, 1995). This portrayal is partly wrong and wholly incomplete and this thesis will argue for change and improvement in IR theory.

Liberalism is not easy to define, but may be captured as 'a societal vision characterised by a belief in the ultimate value of the individual; a preference for societal order as an outcome of self-regulation between groups and individuals and a state bound by representative democracy, countervailing powers and the rule of law' (Kinneging, 1988: 7). The meaning of liberalism will be discussed in more detail in the next chapter and liberalism in IR theory will be the topic of the seventh chapter. Yet even the most superficial inspection reveals that the dominant way of thinking about liberalism in IR rests on a narrow interpretation, often overlooking other

1 Following the convention, throughout the text, the study of international relations as an academic endeavour will be referred to as IR, in capitals, while the object under study will either be named international relations, international affairs, international politics or world politics, in small letters. International relations theory will sometimes be abbreviated into IR theory. 
variants of liberalism. Most notably, there is hardly any classical liberalism in IR, even though it comprises some of the most important liberal thinkers, like Hume and Hayek, and many other influential philosophers and political economists. This is a rather peculiar oversight, since anyone with even a rudimentary knowledge of the great classical liberal writings knows that these works contain many references to international affairs. Part of the explanation of this lack of knowledge is that international relations theorists hardly have studied the development of liberalism' (Long, 1996: 176), which inevitably leads to a focus on a minimum number of writers.

Of the different liberal variants, classical liberalism is not often studied, which also means it is not well understood. Most academics overlook that classical liberalism is a coherent political theory. If writers touch on classical liberalism, it is most often limited to a specific context. The most common example is in the field of (international) economics, where Adam Smith figures prominently. However there is not much regard for his wider thought, nor for the differences between his ideas and those of later writers who refer to him, like Cobden. Outside international economics, 'the classical liberal argument seems to stop at the national border' (Sally, 1998: 4, 35-63). Most work on classical liberalism takes the state or the domestic economy as a framework for research (see for example Barry, 1987). The fact that classical liberalism has something to say about international politics is commonly overlooked. This thesis aims to change that, by bringing classical liberalism into IR. Most people agree that some of the classical liberals have been of enormous importance in political theory, political economy and more generally in the development of the (Western) world. This fact alone provides enough reason to analyse their views on international relations.

The outcome of this research is important for different groups of scholars. IR theorists will be surprised to learn that there is far more to liberalism than they hitherto thought. As will be shown, the classical liberal approach does not 'wish war away' as so many other liberals do; appreciates the balance of power; thinks national feelings are inherent to human nature and offers different solutions to a range of international political issues. For example it calls for a (European) federation and the abolition of development aid. At the end of this thesis it will hopefully be clear that the IR community should revise its accounts of liberalism. The thesis con- 
fronts IR theorists working in the liberal tradition with a challenge to their positions, while academics working in the English School of international relations theory might feel the need to adjust their views on the intellectual history of IR and their approach to certain ideas and topics. People who think of themselves as classical liberals will be challenged to debate viewpoints that have been taken for granted for ages.

There has long been a neglect of the relations between 'political theory' and IR, as well as a lack of attention for 'the international arena' within political philosophy. However, most of the old philosophers do not separate these in their discussion of politics. It is only due to academic specialisation that they have developed in isolation over the past hundred years.

This general pattern resulted in a shortage of good overviews of the international thought of political theorists (Brown et al., 2002: 1-15). Most scholars of international affairs hardly ever glance beyond the surface of the work of a few specific thinkers (Rengger, 2000b: 757-758). Simultaneously, many political theorists regard international affairs as a topic to be avoided. This is regrettable since political theory and international relations theory are intimately related and their aims are more or less the same: to understand and explain political phenomena. The integral study of both 'domestic' and international aspects of political theory is needed for our understanding of politics in general (Clark and Neumann, 1996: 258-259), and classical liberalism in particular. By attempting this, the thesis falls within the bounds of international political theory (IPT), 'that aspect of the discourse of IR which addresses explicitly issues concerning norms, interpretation and the ontological foundations of the discipline' (Brown et al., 2002: 1). IPT is therefore concerned with moral philosophy in IR, it 'seeks to comprehend the human condition and the values fundamental to it - such as order, freedom and justice - as well as the political arrangements and public policies necessary for their realisation or augmentation. International studies is on that view a broadly humanistic subject which involves the scholar in a philosophical, historical, jurisprudential or sociological approach: it is not and could never be a strictly scientific or narrowly technical subject' (Jackson, 1996: 203-204).

There is hardly any literature on the international relations of classical liberals, so not surprisingly a comprehensive analysis of classical liberalism and international relations is also lacking. Hence, of necessity, this thesis is 
exploratory, analytical and agenda-setting for future research. It attempts to offer a first, but big step towards a better understanding and appreciation of classical liberalism in international relations. The central research question is:

- How do classical liberals view international relations and how do these views relate to liberalism in IR theory?

To reach a conclusion about this question, a set of sub-questions will be answered:

- What is classical liberalism?

- What did the most prominent classical liberals write about international relations?

- How are these classical liberals seen by IR theorists?

- Is it possible to built a coherent classical liberal view on IR?

- If so, how does this classical liberal theory of IR relate to other liberal theories IR?

\section{Four classical liberals}

The classical liberal tradition shall be further introduced and defined in the next chapter. Within the limited bounds of a PhD thesis, it is of course impossible to study the writings of all the thinkers in this tradition. Nevertheless, the selection of the prominent classical liberal thinkers David Hume, Adam Smith, Ludwig von Mises and Friedrich Hayek, offers a good basis for analysis.

The main reason to base this book on their thoughts is that they were not only influential among their contemporaries, they also rank among the most important representatives of the classical liberal tradition today. This shows in the volume of the secondary literature on them, the number of references made to their work, the number of lectures, institutes and think tanks named after them and the fact that their work has remained in print. Throughout the history of ideas, many thinkers in the (classical) liberal 
tradition refer to Hume and Smith as their main sources of inspiration and from the 1920s onward this also applies to Mises and Hayek.

Of course, this does not mean to imply that they are the only classical liberals, or that traces of classical liberal thought cannot be found in earlier times. Indeed, the Stoics, Spanish Scholastics, Erasmus, Spinoza, Milton, the natural lawyers of the sixteenth century, the English Levellers and John Locke may be all be regarded as contributors to 'the pre-history of classical liberalism'(Raico, 1989: 1-4; Gray, 1995: 3-16; Powell, 2000). As Craig Smith (2006: 5) points out, it is only with the work of Mandeville that the idea of spontaneous order, one of the central elements of classical liberalism, comes to the fore.

However, compared to Mandeville, Hume and Smith are more important thinkers. Both of them are seen as among the most influential thinkers of the Enlightenment in general (Broadie, 2003: 6) and of classical liberalism in particular (Barry, 1987: 22-35; Gray, 1995: 24-25). This provides sufficient grounds for their inclusion here, but is also important for another reason. Most IR theorists never get beyond a very limited number of thinkers, most notably Kant and Rousseau, in their discussion of the Enlightenment. This leads them to associate this period almost exclusively with cosmopolitanism (Keene, 2005: 135-137). Ashworth (1999: 4) even equates, erroneously, as will be come clear in subsequent chapters, the Enlightenment with a Perpetual Peace Project. More knowledge of the Scottish Enlightenment can counter these ideas (see Van de Haar, 2008).

Mises has been of crucial importance in the revival of the classical liberal tradition in the twentieth century, through his writings and his teaching, both in Austria and the United States. In Vienna he was one of the major heirs and contributors to the Austrian School of Economics, a major strand of economic thinking within the classical liberal tradition. The Austrians defend what they call the subjectivist approach to economics, based on the value humans place on goods and activities in real life, as opposed to the neoclassical school with its mathematical approach and assumptions of rationality and maximisation of utility (see for an introduction Callahan, 2004). Vaughn contends that without Mises there would not have been a revival of Austrian economics at all (cited in Ebenstein, 2001: 388), which also indicates his importance to classical liberalism. Mises taught many of the most important twentieth century classical liberals, so his influence was 
large in direct and indirect ways. His favourite student was Hayek, who became 'the outstanding twentieth century representative of the classical liberal tradition', with an immense influence on economics and politics (Feser, 2006: 2). If one wants to learn about classical liberal international relations, these four thinkers are therefore of crucial importance.

It must be acknowledged that they, like most other classical liberal thinkers, would not primarily consider themselves as international relations scholars. Smith, Mises and Hayek would most likely see themselves as (political) economists and Hume probably either as a philosopher or historian. Certainly, international politics was not often their prime concern. In most cases references to international affairs are widely dispersed in their writings. However, there is no reason to regard these ideas as intellectual sidelines'. All four thinkers addressed international relations in most of their writings throughout their career, which clearly indicates an authorial intention. They wanted their readers to know about their views on world politics and these views were also rather consistent, as shall be made clear in this book. There is no good reason to ignore these ideas or to doubt their value, contrary to the opinion of some scholars (see Ashworth, 1999: 2-3). Rather the opposite, detailed research into the international political views of classical liberals may reveal valuable new or overlooked viewpoints. They have been hugely influential in many fields, therefore it is reasonable to expect that they had direct and indirect influence on their readers' views on international relations, which is another reason for closer scrutiny.

Any selection has its arbitrary sides, so a short explanation on the thinkers excluded from the analysis is required. Perhaps omitting a nineteenth century classical liberal thinker is most remarkable. Yet chronology is not of the greatest importance for an analysis like this, because not all centuries are equally important for the development of a set of ideas. While the ideas of the most important nineteenth century thinkers with classical liberal credentials, for example Acton, Tocqueville and Cobden will be analysed in the course of the thesis, they have not been so important as to warrant a separate chapter on their international relations. Also, the secondary literature on their work already includes their international thought (see for example Hammarlund, 2005; Clinton, 2003). In addition, the development of the classical liberal ideas has been more extraordinary in the late 
eighteenth century and early to mid-twentieth century, than in the time between.

More difficult to justify is the exclusion of Milton Friedman and James Buchanan, both thinkers of great importance for classical liberalism in the twentieth century. However, both acknowledged that they were more influenced by Hayek, than the other way around. For example, Friedman acknowledged that he owed Hayek a big debt for influencing his social and political outlook (cited in Ebenstein, 2001: 267), while Buchanan clearly pays tribute to him as the 'rock upon which classical liberalism rested, in the last half of the twentieth century' (Buchanan, 2005: 91). Given this, the two Americans are excluded in this thesis, but a detailed study of their international relations is an important void to be filled in the future.

This study captures the international relations of the four most influential classical liberals today. It does not claim that these writers also had the most important ideas on international relations among all classical liberals that could have been studied. It is surely possible that the writings of lesser known classical liberal scholars, for example those outside the Anglo-Saxon world, contain more interesting or more innovative ideas on international affairs. Often, this kind of work is either no longer in print or is not translated. Hence in the literature there is a bias towards the English speaking world, although texts in German and Dutch are also taken into account in this thesis. Given the dominance of English-language thinkers in the liberal tradition this choice seems excusable and any gaps it contains should be regarded as an invitation for more research.

Gertrude Himmelfarb (1952: viii-ix) warned that the greatest danger in the history of ideas is to 'over-intellectualise', or to systematise and organise the ideas of a thinker beyond his intention. She offered a wise solution: let the thought speak for itself. This is what will be done in chapters three to six, which provide the first complete overviews and analyses of the international relations of Hume, Von Mises and Hayek, while offering an alternative to the dominant view of Smith's international politics. To enable a better comprehension of those chapters, the historical context of their writings will be briefly sketched in the next section. 


\section{Historical Context}

The selection of classical liberal thinkers studied here has a distinct teleological character: they are regarded as very influential thinkers from an early twenty-first century standpoint. This carries the danger that the subsequent analysis also attempts to answer current questions, even though the thinkers under study were not concerned with these themes (if only because these questions did not exist in their time), or had different agendas. There are many instances in IR theory where the ideas of classical authors - thinkers who wrote about international relations before this was established as a separate academic discipline in the early twentieth century - are taken out of context, or misinterpreted, just to prove a modern claim or 'beef up' a modern theory. At the same time, it is clear that international relations theory is characterised by a set of timeless questions, for example about war and peace (Jahn, 2006b: 3-6).

Context is relevant, because texts are written by authors in unique historical circumstances, with a specific intention and with particular linguistic features. The mistakes of anachronism and teleology loom, as Skinner made clear, although he does not deny that there have are many continuities in Western moral, social and political philosophy (Skinner, 2002: 57-89; also Keene, 2005: 14-21; Pocock, 1989). However, excessive focus on context and linguistics may lead to an explanation of the intentions of the author but fail to reach an understanding of his motives (Hollis, 1988). Boucher (1985: 212-220) argues that Skinner's theory does not suggest how the historian can obtain the knowledge about author's intentions. It seems impossible to gather the required amount of information. Others have countered that the interpreter of texts cannot escape from his own historically bound conventions and language (Keane, 1988), or that the existence of 'perennial issues' in the history of ideas is more important than contextualists are willing to admit (Holden, 2002). An important observation is that there cannot be only one right interpretation of a text or a context, the claim that historical comparisons are impossible or fruitless ultimately also rests on a judgement based on a comparison (Hammarlund, 2005: 6-9; also Stout, 2007). This grounded criticism will serve as the analytical basis here, while it is acknowledged that the contextualist 
arguments are also important for IR theory, if only to recognise the possibility of historical discontinuity (Rengger, 1988: 218-220).

The analysis in this thesis is mainly informed by a belief in historical continuity and, in contrast to Skinner, the existence of a universal debate within political philosophy. It is possible to compare the key concepts in this study over time, because a large degree of similarity between them can safely be assumed. For example, it is obvious that the wars of the twentieth century differ from those in the eighteenth century, at least in scope, weapons used, numbers of people involved, impact on society, et cetera. Yet generally, a war was and is a major event, that causes death and destruction (certainly in the atomic age), has high costs, and in many cases, can lead to the downfall of the leader and the state. From the perspective of state leaders, the importance of the decision to wage a war is comparable, even though the normative valuation may differ from person to person and may depend on particular circumstances. The same applies to the choice of voluntarily cooperation between leaders and officials of states, through international agreements, treaties and international laws, even though the content and force of these agreements might be different. The ideas behind the balance of power, empire or free trade are also roughly identical. It is difficult to think about world affairs without these ideas. Many questions of international affairs return, often unchanged, yet subject to new circumstances (Jackson, 2005: 6-15). Clearly, some issues, like development aid, international governmental organisation and European integration are time bound and the discussion of these phenomena will therefore be limited to the twentieth century theorists. What also changed, of course, were the particular international political circumstances between the period of the ascendancy of classical liberalism, the eighteenth century of Hume and Smith, and the twentieth century Misesian and Hayekian age of positivism and collectivism.

Compared to the previous century, the first half of the eighteenth century was a period of general international political tranquillity for England and Scotland. The seventeenth century brought, among others, the English Civil War of the 1640s, Cromwell, continued religious conflict, the Trade Wars against the Dutch Republic and the Glorious Revolution of 1688, which not only lead to the installation of William and Mary, but later also to the domination of Parliament over the King. Internationally, 
Britain played its part in keeping the European balance of power, countering France in particular. After the Peace of Utrecht (1713) that ended the War of the Spanish Succession, the years until 1740 were largely peaceful because of the balance of power. This changed with the War of the Austrian Succession (1740-1748) and the Seven Year's War (1756-1763), where England successfully fought for colonial and commercial supremacy, especially over Canada (conquered in 1760) and in the Americas. These conflicts were mainly directed against France and to a lesser extent Spain. In the first war Britain fought on the side of Austria, in the second it changed alliances and sided with Prussia. This was part of a larger, Europe-wide change of alliances, now known as the Diplomatic Revolution. In the Seven Years War, British Prime Minister Pitt half heartedly supported the fight of the British allies in Germany to weaken the French defence of its colonies. The raiding of their coast and colonial possessions also weakened the French. Some of the Anglo-French hostilities broke out in the colonies, from a British perspective mainly to prevent France connecting its Northern (Canada) and Southern (Louisiana) territories by a corridor. For the colonists, this war was costly, and brought all kinds of prohibitive measures to the colonial trade with the French. The subsequent English demand for colonial contributions for war expenditure, together with many other grievances about the limitation of freedom, did much to estrange the colonists from the Motherland. This would eventually lead to the call for independence and the American Revolution of 1776-1789.

Hence, Hume and Smith initially lived in a time without much international conflict. European states used the balance of power to keep order. Later, international turmoil set in, with a prominent role for the overseas empires of the European states. This was particularly the case for England, which was not heavily involved in Continental wars. Since the Act of Union (1707) Scotland was united with England, as it was no longer capable of independence, not least because of economic problems. In practice though the Scots enjoined a kind of semi-independence for several decades, as the English only interfered in Scottish affairs when there was a serious threat to the Union. The Union with England was also a way to gain more access to English and imperial markets. These and other political and economical issues were part of the public debate, which took place throughout the century, and which resulted in many of writings which made the Scottish 
Enlightenment, a period of cultural and scientific creativity and discovery, so important. However, attempts to end the Union were also made. A famous rebellion was by the Catholic 'bonnie' Prince Charlie, who lost his initially successful campaign to restore the Jacobite rule of the old Stuart Kings in Scotland. In intellectual circles, theorising about nation, religion, Highland versus Lowland, the Royal family, national defence through militias and the place of Scotland in the Union was important. Domestically, there was fierce controversy between the Tory and Whig parties, which led to a bipartisan political climate. The Scottish Enlightenment was part of the greater European Enlightenment and was also stimulated by the general outward-looking mentality of the Scots. They produced remarkable works in the history of thought and cultural expression, which laid some of the critical foundations of the modern world. A pivotal role was played by Hume and Smith. As we shall see, their focus was on history, moral philosophy, jurisprudence and political economy. Part of the ongoing economic discussion since the seventeenth century was on trade, with free traders opposing the mercantilists. Hume and Smith supported the first group and Smith's systematic approach was new. Trade with the colonies was part of the discussion. International affairs, questions about sovereignty, war, balance of power, empire and trade affected the lives of the Scottish thinkers considerably without dominating the intellectual climate. These circumstances were reflected in their writings.

Questions of international politics were of utmost importance to Mises and Hayek and their contemporaries. A major difference compared to the time of Hume and Smith, was of course that the modern state had taken a great role in the lives of people. Related to this was the idea that it is possible to improve the world through the implementation of positive law and economic planning. Political doctrines favouring such a large state role were influential, whereas liberalism had gone through a radical decline. Several kinds of collectivist and totalitarian doctrines, often with a strong nationalist component, began to dominate world affairs from the 1920s onwards. Hence, Hayek and Mises were not in the mainstream, but were among a small group of men arguing against the prevailing spirit of the day.

Mises and Hayek both fought on the Austrian side in the First World War, after which Austria was reduced to a small rump state around Vienna, 
without the Empire and political role it had had for so many centuries. Austria was in a very bad state, politically characterised by perpetual instability and factionalism, economically by huge inflation and drives towards socialism. The economic crisis of the late 1920s and early 1930s, made the situation even worse. At the same time, the shadow of the developments in Germany loomed large, eventually leading to the incorporation of Austria into Nazi Germany. Like so many of their fellow countrymen, Mises and Hayek had already left the country by then. Hayek lived in London from the 1930s onwards; Mises first taught in Geneva, before fleeing to the US in 1940 .

In the pre-war years many people foresaw another war, in part due to the failure of the League of Nations. This led to the publication of numerous alternative peace proposals, with a prominent role for international federation. After 1945, the world was dominated by Cold War politics and the battle between communism and capitalism. Mises and Hayek were arguing in favour of capitalism, again against the dominant socialist current in Western intellectual circles.

\section{The English School}

To fully appreciate the value of the international relations of Hume, Smith, Mises and Hayek, an appropriate theoretical framework for analysis is needed. Most IR theories focus on one particular element in their attempt to understand international affairs, which limits the possibilities for analysis, because the chosen framework more or less determines its outcome. For example, a realist approach would focus on the realist elements in the thought of the classical liberal thinkers, while neglecting or downplaying other parts. To avoid this, a theory with a wider scope is needed. The English School of IR is a particularly attractive alternative. It offers an effective device for the analysis of the international thought of political thinkers. It is anti-positivist and historical in its approach to IR, which makes a good fit with classical liberalism. It also combines in one analysis the roles played in international affairs by the individual, their communities and the larger system. There is enough room for improvement of the English School theory (see Linklater and Suganami, 2006: 259-272), so it is worthwhile 
to see if classical liberalism can contribute to this. The use of the English school as an analytical device is relatively novel, so there is a need to elaborate, after a brief overview.

\section{Overview}

The English School approach to IR, sometimes called the classical approach, tries to understand international relations by considering classical ideas on international politics. That is by including the ideas of philosophers who wrote on this topic before IR became an independent academic discipline (in the early twentieth century). The English School approach entails 'theorising that derives from philosophy, history and law and that is characterised above all by explicit reliance upon the imperfect exercise of judgement' (Bull, 1969), intentionally contrasting with the positivist theories of IR developed after the 'behavioralist revolution' of the 1950s. Martin Wight has been a main figure associated with the English School, although his thought cannot be confined to this tradition (Hall, 2006b: 157). He argued that world politics cannot be understood without taking the moral and cultural basis of its participants into account, for him historical and theoretical enquiry were intimately related (Bull, 1994: xxxiii). As shall be shown throughout the thesis, classical liberals take the same unified approach. They assert that their ideas about the individual, founded in natural law, are universally applicable and of equal importance in domestic and international politics. Although they recognise the differences between these two spheres, classical liberals hold that international politics is also a realm of principled politics, not just of pragmatic reactions to the circumstances and issues of the day.

Although there is discussion about the precise membership of the English School, Wight, Bull, Vincent, Butterfield, James, Watson, and Porter are generally included. Most of them were members of the British Committee on the Theory of International Politics, that existed from 1959 to 1984 (Linklater and Suganami, 2006: 12-42). According to Dunne, three common threads underpinned the Committee's approach to IR. First, the members' self-identification with a particular tradition of enquiry, consisting of an awareness of a central body of literature, a set of central questions 
and a common agenda. Second, an interpretative approach to the subject and a rejection of the (positivist) scientific study of IR. Third, ethical concerns and normative questions are regarded as central to theoretical inquiry into world politics (Dunne, 1998: 5-11). These views more or less survived to this day and can still be distinguished in the work of different thinkers currently associated with the English School, like Jackson, Mayall, Dunne, Buzan, Hurrell and Wheeler.

The English School is one of the most important approaches to international politics, although its influence is greater in the United Kingdom than in other countries. The central claim of the English School is that sovereign states form a society. This society has an anarchical nature, because there is no authoritative power above the states to which they have to submit. The societal nature of international affairs accounts for the continued existence of a degree of international order, which would be much lower, if not absent, without sovereign states. English School theorists do not deny an important role for violence in international relations, but point out that its outburst is limited and controlled by a number of international common practices, referred to as 'institutions', for example the balance of power and international law. The members of international society have become conscious of regulatory rules, institutions and common values. Generally, English School theorists take a middle position on a range of possible views on order in international politics. For them, the world is more civil and orderly than realists think, but less peaceful and open for fundamental change than idealists argue (these positions will be further defined and introduced below). Therefore they feel only a limited degree of progress, defined as a movement towards lasting peace, is possible in international relations (Linklater, 2005: 84-89).

The interpretative approach to the academic study of international politics by the English School theorists comprises four elements, most eloquently introduced by Bull. First, the subject matter of IR. This is not just the study of 'interstate relations', but should attempt to establish a body of general propositions about the global political system, including regional associations and non-state actors such as international organisations, businesses, social groups and individuals. IR theory should also stay clear of positivist testing of hypotheses. It should theorise in terms of the formulation of concepts and their mutual relations. Second, historical understanding is 
crucial for academic knowledge of international politics, since history and historical interpretation inform all international actors. Third, there is no escape from values in IR. They influence the selection of topics studied by IR theorists, despite -in Bull's view worthwhile- attempts to separate statements about facts from values. Particularly, IR academics should refrain from giving policy advice, as this is the surest way to undermine academic integrity. Bull believed it actually hampers the generation of information useful for general practitioners. Fourth, IR is fundamentally a normative undertaking. The central question in world politics is how to get to a form of international society that is both orderly and just. This does not require the formulation of 'ideal theory characterised by fictional assumptions and make-believe states'. Bull was convinced IR theorists need to stay close to state practice, therefore they should deal with the actual ideas that IR practitioners hold and seek to implement (Dunne, 2007: 130-132; Bull, 2000).

As pointed out by Buzan (2001) the initial English School theorists spent much time on the study of the nature and history of state systems (Watson, 1992: 2-3; Bull and Watson, 1984; Wight, 1977). Vincent added research on humanitarian intervention and human rights (Dunne, 1998: 161-180), a theme still attracting attention, for example by Dunne and Wheeler (Linklater and Suganami, 2006: 109, 225-230). Also much debated is the concept of international society itself (see for example Bellamy, 2005a; Roberson, 2002). Alan James and Barry Buzan are among the scholars who have focused on the boundaries between the different traditions in the English School (Little, 2002: 61-64, 74), to be elaborated below.

In recent years attempts have been made to relate English School theory to other strands in IR theory (for example Wæver, 2002). Most particular, a relationship with constructivism has been established (Reus-Smit, 2005). Like English School theorists, constructivists argue against a strict rationalist and positivist approach in IR. They emphasise that international relations is about social construction. This means that social phenomena like states, alliances and organisations are the result of human interaction, they are constructed by humans in specific cultural, political and historical contexts. Like people, these social constructions are changeable over time which allows to explain or understand change in international affairs. Con- 
structivists see an important role for rules, norms and language at the international level and deny the overarching influence of structure. States and other actors constantly interact and by doing so shape the world (Fierke, 2007). Both the English School and constructivism regard the inter-state order as a fundamentally social sphere, where rules, norms and institutions are expressions of shared knowledge and shared values. Their main difference is about the agents in international politics. Constructivists regard states as acting units, while English School theorists emphasise that only humans, such as diplomats or state leaders, are able to act on behalf of the state (Dunne, 2007: 132). This is not the right place to further comment on these debates. Suffice it to note that English School theory is in full development and attracts increased attention from a growing number of theorists, around the world.

Particularly important for this thesis are some of the underdeveloped areas within the English School, as these may be filled by classical liberalism. Often noted is the neglect of international economic issues in English School texts (Alderson and Hurrell, 2000: 67-68; Buzan, 2005; Linklater and Suganami, 2006: 175), as well as the need to study the European Union. Especially relevant are Rengger's (1988) assertion that the link between the English School and political theory is underdeveloped yet natural and Hurrell's (2001: 493) argument that the English School has altogether neglected the history of thought. More specifically, some scholars argue that the English School should attempt to understand liberal ideology as a major source of norms, rules and institutions (Buzan, 2001: 485-488). This thesis will attempt to address these points.

\section{Analytical device: the three traditions}

The English School is famous for its use of three intellectual traditions: Realism, Grotianism and Kantianism, to distinguish between different views on international relations. Important is that 'the[se] categories [....] retain their relevance as explanatory tools and normative benchmarks' (Dunne, 2007: 145). Therefore it is rather surprising that there are hardly any attempts to use these traditions as analytical devices to determine the domi- 
nant outlook in the international thought of political thinkers. Yet that is exactly how they will be used in this thesis.

The tripartite classification was introduced by Martin Wight in his lectures at the London School of Economics and Political Science (LSE) in the 1950s and further developed by Bull. Strictly speaking, Wight introduced a fourth tradition, 'inverted revolutionism', which includes total pacifism. This is a position Wight himself held between the 1930s and the end of Second World War (Porter, 1978: 68). He attempted to improve on the existing dichotomy between realists and idealists, introduced by Carr and further popularised by writers like Morgenthau. Wight never intended the traditions to be absolute and completely accurate descriptions of reality, his main purpose was to enable a fruitful dialogue on international relations (Hall, 2006b: 142-144). According to Wight himself, there is no strict or clear cut divide between the traditions, as there are many intermediate or partly overlapping positions in the thought of individual thinkers. The traditions are broad, but distinct. In theoretical discussions they should be regarded as the looser versions of paradigms in natural science (Wight, 1977: 38-39). In this thesis, the three traditions will be used as a theoretical framework of reference, hence as a yard stick that enables the interpretation of the international relations of the four classical liberals. It will also be used to determine the originality of their ideas and to position classical liberalism within international relations theory. Where applicable, the elements of all three traditions in the writings of Hume, Smith, Mises and Hayek will be examined. Thus, the 'internal dialogue' on international relations in their writings will be presented.

Wight and Bull were unfortunate in naming the traditions. Wight introduced them as the three R's: rationalism, revolutionism, and realism. However, the use of the term rationalism has been a source of great confusion. Bull preferred to speak of Kantianism, Hobbesianism and Grotianism. This lead to numerous publications pointing out that Hobbes was hardly the ideal realist (Williams, 2006b; Vincent, 1981), Grotius no full Grotian (Cutler, 1991; Jeffery, 2006; Keene, 2006) and Kant not really a Kantian (Hurrell, 1990; Franceschet, 2006). These kinds of arguments should not be brushed aside and serve as a warning not to equate the traditions with particular thinkers. Yet, as Wight foresaw, this type of work also demonstrates that some, or even most elements of the thought of these 
three thinkers can indeed be placed within particular traditions. Partly as a reaction to this critique, the more common distinction used in the field is between international system, international society and world society (Buzan, 2004: 6-26).

To avoid confusion and following current mainstream English School use, in this thesis the distinction between international system, international society and world society will primarily be used and the "three R's" completely avoided. However, because the labels Realist, Kantian and Grotian are now part of the canon in IR theory, it would actually be more confusing to completely avoid them. So they will be used as well, which also has some obvious 'short hand' advantages.

\section{Realism or international system tradition}

Realism, in different variants, has been the most important tradition in international political theory. It serves as the bench mark for most other theories and approaches (Der Derian, 1995:3-6). Its basic features are relatively straightforward, so a short introduction suffices. Most realist thought has a foundation in Thucydides, Hobbes, Machiavelli and Clausewitz, as is clear in the writings of the most important twentieth century realists Carr, Morgenthau, Niebuhr, Kennan, Kissinger and Waltz. Realists hold that the international world is an anarchic system of states, without a central ruler. This situation is often equated with a Hobbesian state of nature. The notions of power, security and survival are the dominant drivers for the behaviour of state representatives and power relations and perceptions of national interest determine the course of events in international politics. The ordering mechanism is the balance of power, which comprises states attempting to counter the dominance of other states by forming coalitions. These coalitions are always fragile and temporarily, because states may try to tip the scale of power to their own advantage. Relations among states are not in any way limited or determined by rules, law or international institutions. These exist, but only because they serve a short term advantage. Ultimately, rules do not matter much. Diplomatic relations and general engagement to a set of international rules are expressions of power. There 
is no room for morality in world politics and war is normal feature of it (Bull, 1966: 35-43).

Hence, the struggle for power, defined as man's control over the minds and actions of other men, is central in realist theory. Power may not always be the ultimate aim of all statesman. For example some may regard freedom of a higher order, but their immediate aim must always be power. Without it, those other goals cannot be realised (Morgenthau, 1948: 13). The systemic constraints of the anarchic nature of international relations mean that state leaders are faced with a security dilemma: there is always the chance that another state or alliance of states will use military action against them. The survival of the state is never secured, hence this must be at the centre of their international action, which severely limits the room for manoeuvre (Donnelly, 1992: 86-88). For realists, war has been especially important in shaping the character and the development of the modern state. Rebuffing idealist liberals, Butterfield, the most realist early English School author, argues:

'One of the reasons why it is so difficult to secure Utopia in our time, or even anything very satisfactory in the way of the League of Nations, is the fact that no man has yet invented a form of political machinery which the ingenuity of the devil would not find a way of exploiting for evil ends. [...] It is essential not to have faith in human nature. Such faith is a recent heresy and a very disastrous one' (Butterfield, 1950: 38-47).

For Wight, realism means 'the acceptance of the disagreeable aspects in life', such as violence, sin, suffering and conflict. It concentrates on the actual rather than the ideal, and tends to be pessimistic about human nature. Realists also think that states have the absolute right to expansion, thus they are also firmly imperialist (Wight, 1991: 15-17, 25, 55-56; also see Wight, 1995).

\section{Kantian or world society tradition}

In the English School, the opposite of realism is the Kantian or world society tradition, which is relatively underdeveloped (Buzan, 2004), although 
the number of scholars working in this tradition is rapidly growing. Wight uses the category to group all thinkers with revolutionary traits, who in his view combine a belief in the moral unity of the society of states with the missionary zeal to accomplish this cosmopolitan ideal. He distinguishes between military revolutionism and soft revolutionism. Prominent examples of the first variant are the French Revolutionaries and the twentieth century totalitarians, such as the Fascists, the Nazi's, the Marxists and the Communists. Wight claims they are all influenced by Rousseau and the theocrat' Calvin. A common thread in military revolutionist thinking is the rulers' claim to be the true representative of the general will or of God. The use of violence is not avoided if needed to create 'the brotherhood of mankind'. Soft revolutionism starts with the Enlightenment and Kant, and later comprises people like Carnegie, Wilson, Roosevelt and Nehru. It advances more peaceful ways to reach its ideal (Wight, 1991: 8-12, 47). As Hall (2006b: 145) notes, such a large and diverse group of theorists did not have the consistency of doctrine Wight imposes on them. Yet a general pattern of thought is recognisable and appears frequently in political writings.

Modern English School theory mainly analyses soft revolutionism. This example will be followed here. Therefore the world society tradition will be defined by an optimistic and perfectionist view on human nature and the desire to revive the idea of the world as a single human republic, or a world state. As Wight stated, Kantians think politics should 'prescribe human goals, the right of moral judgement and duty of action' and must ensure that national interests converge in the name of the permanent solidarity between people. The balance of power is rejected, as is war (Wight, 1991: 27, 40-42, 105, 114, 173, 221, 238). The general goal of the Kantians is to overthrow the system of states and replace it by a cosmopolitan society, a community of mankind. Rules for inter-state coexistence will be ignored to reach universalist goals (Bull, 1995a: 24-25). Nowadays, the world society tradition is also closely associated with concerns for transnational justice and the expansion of international law to include broadly defined human rights. The sovereign rights of states must be diminished, which is also an expression of the growing influence of international governmental and non-governmental organisations in world politics (Dunne, 2007: 140-144). 


\section{Grotian or international society tradition}

The Grotian tradition is most closely associated with the English School, especially in the work of Bull and Wight (Dunne, 1998: 1-12). Sometimes theorists do not even make a distinction between the English School and the international society tradition, but that interpretation is too limitative. The essential idea of the Grotians is that states form a society of sovereign equals, with no political power above them. International society has an anarchic nature and war and the balance of power are important phenomena (commonly referred to as 'institutions') which keep order. Grotians differ from the realist position, because they also value the binding influence of the institutions of international law and morality. International politics is more than power struggle and Realpolitik (Wight, 1991: 164-168; Little, 2006; Bull, 1995a: 97-121). Interestingly, this lead Hurrell (2002: 18) to call the Grotian tradition in the English School 'a form of liberal realism'. As shall become clear, this makes him - with Jackson and Rengger - one of the few IR scholars who are aware of the more bellicose sides of liberalism in IR.

International society is a group of states which conceive themselves to be mutually bound by a common set of rules and institutions. It is characterised by a measure of 'solidarity', although Grotians differ among themselves about the precise degree and relevance of international human bondage. Besides protecting their own survival, states also want to preserve international society (Kingsbury and Roberts, 1990: 6-12). In Bull's definition, international society is:

'a group of states, conscious of common interests and common values, [who] form a society in the sense that they conceive themselves to be bound by a common set of rules in their relations with one another, and share in the workings of common institutions. If states today form a society .... this is because, recognising certain common interests and perhaps some common values, they regard themselves bound by certain rules in their dealing with one another, such as that they should respect one another's claims to independence, that they should honour agreements into which they enter, and that they should be subject to certain limitations in exercising force against one another. At the same time they co-operate in the workings of institutions such as the forms 
of procedures of international law, the machinery of diplomacy and general international organisation, and the customs and conventions of war' (Bull, 1995a: 13).

With the Kantians, the Grotians share the idea of society, the recognition of the role of values and morality in international relations and the emphasise on the importance of international law. However, they oppose attempts to create a cosmopolitan state and do not believe in world society. The role of war is sometimes positive and the balance of power often prevents conflicts from turning violent. The international society tradition takes a intermediary position in English School theory and is therefore often referred to as the via media (Linklater, 2005: 84-86).

As indicated, the claim of importance of Grotius' thought for this tradition has been disputed, not least because of the different ways Wight and Bull interpreted his ideas (Jeffery, 2006: 113-138). Still, there are numerous elements of his writings relevant to the international society tradition. Other natural law theorists, like Suarez, Vattel, Gentili, Vitoria and Pufendorf, are also in some way contributing thinkers, but Grotius was one of the first to describe a system of international law. He equates the Roman ius gentium, the collection of rules and customs common to the tribes and nations of the Roman empire and the ius naturale, a set of ethical rules of Christian divine origin (Hinsley, 1963: 165). Grotius regarded individuals as ultimate units of all law. States are not the sole actors in world politics, there is a universal moral order. States are sociable, and just like individuals they should be bound by norms and customs, embodied in the law of nations This is a clear sign of the natural law influence in Grotius' thought, which serves as a universal standard of justice, also for the actions of states (Cutler, 1991: 44-49). Consequently, there is a strong relation between the just war tradition in philosophy and the international society tradition (Wight, 1991: 233-234, 242). The basic concept is that war is inevitable, but that only certain wars are justified. A just war is fought for a just cause, like the enforcement of rights of self defence, the recovery of property or the infliction of punishment. Other wars are unjust and should not be waged, not even for reasons of state (see Rengger, 2002; Elshtain, 1992a; Rengger, 2004; Reed and Ryall, 2007). 
For the Grotians, international law is binding, following the maxim pacta sunt servanda, which is a legal and ethical norm (Wight, 1991: 238). Since the nineteenth century, international law covers many other fields, as a consequence of the increase in international treaties and international conferences. International law no longer partly relied on custom and tradition, but almost exclusively became positive, written law (Nussbaum, 1954: 196-224, 251, 277). Grotians generally regard this as evidence that the world has many traits of an international society, with a central role for diplomacy, the prime means of communication and negotiation between the representatives of the states (Wight, 1991: 180-188; Hall, 2006a). Modern international society is at its core still a diplomatic system and diplomacy its foundational activity (Jackson, 2005: 51).

As indicated above, there are differences among Grotian scholars with regard to the degree of human unity in international society. The most well known divide is between pluralists and 'solidarists'. The first think that the world is an international society of states with its own rules and laws, although these rules are not as far reaching and restrictive as in domestic society. For pluralists this means that violence and power remain important in international relations and that aiming for a world without these features is not possible and therefore useless. The solidarists disagree, they see possibilities for a more peaceful world with closer ties between people. They also assert that the interests of the whole society outweigh those of the constituent states. More extensive common goals for humanity can, and should, be formulated (Hurrell, 2002: 25-27). Their disagreement focuses on war, the sources of international law and the status of individuals. Pluralists see world politics determined by a large number of states, based on the different ways communities of people choose to co-operate and live together. This will differ greatly from group to group, resulting in limited agreement on issues between those communities at the international level. International relations have as a prime purpose the establishment of a moral and legal framework that allows those communities to do as they see fit, with a minimum of external interference. Pluralists do not believe in international redistributive justice, or for that matter (most) non-classical human rights. They also think that it is impossible to reach international agreement on substantive moral issues, since these must be based in a strong cultural context, which cannot be universal. Aiming for universal 
ethics is running the danger that world order becomes seriously disturbed. In contrast, solidarists contend that it is possible for different communities to abandon warfare is most instances and to reach agreement on ethical issues, as they argue shows for example in extensive international agreements on human rights or the on economic issues (Bellamy, 2005b: 9-11). Bull and Wight were pluralists, as is Jackson (Wheeler and Dunne, 2002: 50 53), while many current English School scholars lean towards a solidarist position (Linklater and Suganami, 2006: 59-74; Williams, 2005). Where relevant the distinction between pluralism and solidarism will be made when analysing the thought of Hume, Smith, Mises and Hayek.

\section{Methodology}

This thesis is partly a work in the history of ideas with a focus on intellectual traditions, namely classical liberalism and those of the English School. Before turning to the main argument, the most important methodological issues associated with this type of research are addressed and some of the commonly used terms explained.

\section{Traditions}

Many IR-academics use the term tradition, but most of them fail to provide a definition (for a discussion see Jeffery, 2005: 61-62). A good exception is Knutsen (1997: 11-12) and his definition of an analytical tradition, 'an inherited pattern of thought or a sustained intellectual connection through time along which scholars stipulate certain concepts, themes and texts as functionally similar' will be used here. According to Greenleaf, the relations between the thinkers within a tradition are based on the existence of influence and connection between them, although no one author exhibits each and every characteristic found within it. A tradition is of a certain fluidity to allow change over time. Yet it retains its basic features and identity, the concept of tradition implies unity in diversity (cited in Boucher, 1985: 114-119). One of the aims of this thesis it to show that classical liberalism is a tradition in this pure sense, that it is characterised by a large degree of 
similarity in thought between the thinkers, who refer to and call upon each other, recognise their mutual intellectual debt, and where the later thinkers continue to built upon the work of their predecessors.

Within the English School, which is sometimes called 'the traditions tradition', the three traditions function to identify normative orientations within and between thinkers. The use of traditions prevents scholars from considering the present as unique and makes it clear that today's problems in international relations are often no more than variations to older themes. The traditions serve as a reference point against which change, or the lack of it, can be measured. They should be seen as starting points for discussion about IR theory, not as a set of definitive answers (Clark, 1996). The normative function of the traditions shows in their capacity to provide opinions about the rights and wrongs in foreign policy (Nardin, 1992: 1). As indicated above, the English School traditions are not meant to be completely mutually exclusive, they serve as intertwined starting points of analysis. As Wight (1991: 260) was at pains to point out: 'they are not like three railroad tracks running parallel into infinity'.

The major value of the three traditions as frameworks of reference lies in their ability to analyse the work of an author, especially several works written during a lifetime, by distinguishing between several, sometimes conflicting, elements. It is a useful tool to further our understanding of the international outlook of a particular author (Clark and Neumann, 1996). Within the thought of an individual thinker there is always one tradition that dominates, which allows a classification of the thinker into a certain tradition. Again, not one thinker fits perfectly and only in one tradition, since these are 'ideal characterisations of styles of thinking .... in the history of European philosophy' (Boucher, 1991: 127-131). The three traditions are 'distinctive, long-standing and evolving ways of reflecting upon human activity', connecting the texts of different thinkers, despite the fact that these were written in different places and times (Jackson, 2005: 1516).

The use of traditions is grounded in the Wightean belief that political ideas do not change much and that the range of ideas is limited. According to Yost, Wight was influenced by Tocqueville in this respect, who wrote: 
'it is unbelievable how many systems of morals and politics have been successively found, forgotten, rediscovered, forgotten again, to reappear a little later, always charming and surprising the world as if they were new and bearing witness, not to the fecundity of the human spirit, but to the ignorance of men (Yost, 1994: 265)'

However, not all modern writers are convinced or satisfied with the presence of traditions in international relations theory in general and the English School in particular (see for example Dunne, 1993). Some argue that there is no use in categorisation for its own sake, or that the reliance on traditions limits the research agenda to only a small range of problems. Also, in contrast to the discussion above, there is a claim that it is methodologically illegitimate to use traditions of thought (Clark, 1996: 6-10). Despite Wight's attempts to provide historical evidence (Yost, 1994: 273-274) some academics, most recently Jeffery, contend that many 'old' traditions are quite recent in origin. Therefore many traditions are invented, because they are based on erroneous claims about a presumed pattern of historical transmission, which lacks historical evidence (Jeffery, 2005).

The weak point of most criticism is that it is limited to exercises in meta-theory. Generally, the claims about the non-historical nature of traditions are made without much evidence from the history of ideas. One looks in vain for attempts to identify the alleged lack of tradition. The least one would expect is that the claim of invention rests on a thorough historical analysis of different (non-existent) patterns and lines of thought. Even the critics who turn to the history of ideas hardly ever look beyond the thought of the 'flag ship' thinkers of the three traditions, Hobbes, Kant and Grotius (for example Jeffery, 2006: 51-138; Keene, 2005: 6). With the exception of Bartelson (1996) they focus on elements of discontinuity through time. A possible reason is that because the three traditions are hardly ever used as an analytical device, it remains unknown if, how and to what degree other writers are influenced in their writing about international relations by the ideas contained in the three traditions. This applies especially to those authors who fall outside the limited number of 'usual suspects' widely acclaimed for their contributions to IR theory (Jahn, 2006b: 8-9).

In contrast, the prime concern here is with the international relations of an atypical, yet in many ways hugely important set of thinkers: the 
classical liberals. If it can be shown that they are part of a political theory tradition, and that there are important similarities in their ideas on international relations which enables a pairing to one of the three traditions, an important argument against the claims about the alleged 'inventedness' of the three traditions can be made.

\section{Terminology}

Some commonly used terms in this thesis may be a source of confusion, hence they will be clarified. First of all, there are many terms for thinking in theoretical terms about political relations beyond the national border. Sometimes it is called international theory or theory of international politics. Other general terms commonly used, although not always with identical meanings, are international political thought, international political theory, international thought, or international relations theory. All these terms and their meanings are contested (Rengger, 2000a: 1) and it goes beyond the purpose if this book to provide a full discussion. The broadest in scope and most easily understandable term appears to be international relations theory. Therefore this will be the term of choice in this text, to refer to the analytical and normative theorization of interstate relations, transnational relations and the international system itself' (Halliday, 1994: 4-8).

Much use will also be made of other contested terms in political science, namely state and nation. Thinking about international relations started with the formation of different communities (Keene, 2005: 10-11), here defined as groups of people living together and bound by a common government and other ties such as customs, ethnicity, religion or language (Watson, 1992: 16). Following Dunleavy and O'Leary, government is 'the process of making rules, controlling, guiding or regulating'. The state then, in their organisational definition, is 'a set of governmental institutions of relatively recent historical origin' and is characterised by:

- recognisable separate institution(s), so differentiated from the rest of society as to create identifiable public and private spheres

- sovereignty, or the supreme power within its territory and by defi- 
nition the ultimate authority for all law, i.e. binding rules supported by coercive sanctions. Public law is made by state officials and backed by a formal monopoly of force

- he extension of the state sovereignty to all individuals within a given territory, including those in formal positions of government or rule making

- The power to tax its subject population to finance its activities.

(Dunleavy and O'Leary, 1987: 1-2)

The advantage of this definition is that it decouples the state from human communities, which is also a central idea in classical liberalism, as shall be illuminated in the next chapter. There are and have been many communities without a state, although they all need some measure of government to enable their co-operation. Important is that these rules for living together do not necessarily originate in the state.

A modern state is not the same as a nation. According to Gellner, two men are of the same nation if they share the same culture, where culture means a system of ideas and signs and associations and ways of behaving and communicating; and if they recognise each other as belonging to the same nation. Nations are the artefacts of men's convictions, loyalties and solidarities (Gellner, 1983: 7). Guibernau adds three criteria: the attachment to a clearly demarcated territory, possession of a common past and a claim to the right of self-rule. State and nation do not often coincide. Nationalism may be regarded as the political movement to create a state for a nation. Vice versa, the nation-state is a state whose members lack a common past, for example because of the drawing of new borders after a war, and where its leaders actively aim to create a nation and develop a sense of community (Guibernau, 1996: 47-48).

Hume and Smith wrote in a time when the process of state formation was in full swing. They were not familiar with the modern state as defined above and generally used the terms nations and countries, which shall be understood in the cultural and territorial way defined above. In contrast, Mises and Hayek were very much aware of the development of the modern state and of the rise of nationalism from the nineteenth century onwards. Consequently, they were also much more aware of the existence of public and private spheres within a state. The public sphere is related to the activi- 
ties of the state institutions. In this thesis references to the private sphere will be made with the term society, which will be meant to comprise all contacts between natural persons, and their non-state organisations, like churches, non-governmental organisations, clubs, et cetera (for a different approach see Van Dun, 2006). The term nation and country shall be used in their cultural and territorial meaning and the term state will be used for the political entity.

Thinking about the rules of conduct between states is widely seen to have commenced with the work of writers like Suarez and Grotius, who derived from natural law a set of rules applicable to international relations. In the eighteenth century these rules were known as the law of nations, which applied to issues like the just causes of war, the conduct in war, treatment of prisoners, acquisition of sovereignty and booty through conquest, neutrality, intervention, maritime law, treaties et cetera (Stanlis, 2003: 85-89). While the law of nations was much more restricted in volume and range than modern international law (see for example Simmons and Steinberg, 2006), there is certainly enough continuity in the idea itself, namely the promotion of international order through rules and agreements, to warrant comparison over time. In this thesis international law is the general term used. In the course of the text definitions for other common terms will also be provided.

\section{Theory}

Chapter seven of this book presents an outline of a classical liberal theory of international relations that is based on the analysis and interpretation of the ideas of Hume, Smith, Mises and Hayek. This theory will then be compared to non-classical forms of liberalism in IR. Here some preliminary methodological questions are addressed concerning the procedure of distilling a coherent theoretical outlook from the work of authors for whom producing a comprehensive theory of international relations was not part of their intentions.

As indicated in the previous section, international relations theory is defined as the analytical and normative theorization of interstate relations, trans-national relations and the international system itself. However, 
there is no generally agreed definition of what constitutes 'theory' in IR. Alternative characterizations abound, such as 'speculation about the relations between states' (Wight, 1966: 17), 'the body of general propositions that may be advanced about world politics' (Bull, 1995b: 181) and many other suggestions (see Burchill and Linklater, 2005; Dunne et al., 2007). Taken together they imply a degree of uncertainty about the questions to which a theory of international should provide answers, as well as about the criteria for determining whether one answer is better or worse than another. Despite -or because of- this lack of definitional agreement, many different IR theories have been introduced. Besides ontological claims, the major differences between these theories are of a methodological and epistemological nature. Consequently, the disciplinary history of IR partly revolves around methodological debates. Of central importance is the divide between scholars who want to explain international relations 'scientifically' and those who want to understand it 'reflectively'. Put briefly, the former prefer positivist methods based on the natural sciences; they emphasize data collecting, observable phenomena, measurement, statistics and other quantitative techniques. They claim that this is the only way to get true scientific knowledge about international affairs. The large and diverse group of reflectionists counter that it is impossible to deal with complex social and political processes in such a way. They focus on interpretative methods (qualitative, discursive, historical) and the importance of beliefs and ideas in the constitution of social reality (Kurki and Wight, 2007; Hollis and Smith, 1990). It goes beyond the purpose of this thesis to discuss these issues in detail. Suffice it to note that theory in international relations is multi-faceted and methodologically and epistemologically pluralist. There is not one right or true way to theorise about international relations.

Apart from methodological divisions, there is also the disciplinary divide between political theory and international relations theory mentioned above. Scholars who sought to bridge this gap, the international political theorists, have not had much influence on the development of IR theory (Boucher, 1998: 4). To the extent that this is true, it means that there is no readily available and certainly no widely accepted method for developing an IR theory out of political theory analysis. However, this book cannot avoid to try to tackle this problem. Given the nature of the writings of the classical liberal authors it should obviously not be expected that the theory 
in chapter seven is a strictly positivist social science IR theory. The expected result will fall under the broad rubric of normative theory (Jackson, 1996: 208-211) and conforms to the idea of continuity in the history of ideas and the existence of a classical liberal tradition.

In the chapters analysing the ideas on international relations of the four classical liberals, the three English School traditions (introduced above) will be used as means of interpretation. Through consistent comparison, the ideas of Hume, Smith, Mises and Hayek are put in an English School perspective and will be compared to the prevailing views on them among IR scholars. This should lead to insights in the thought of these four thinkers that are relevant for our purpose of distilling a classical liberal IR theory from their writings.

Before introducing a classical liberal theory of international relations some preparatory steps need to be taken. First, classical liberalism must be defined, which shall be done in chapter two. Second, the relevant views of Hume, Smith, Mises and Hayek that make them representatives of the classical liberal tradition must be identified. The first sections of chapters three to six are dedicated to that purpose.

On this basis it is possible to start collecting the ideas on international relations they have in common and attempt to organise them into a theoretical framework that is capable of addressing not only fundamental but also topical questions in the field of IR theory. Also, it will be determined whether their views on international relations are consistent with the political theory tradition to which they in other respects so clearly belong. In itself this is a logical expectation, as it would be curious if they shifted their framework of thought, or no longer focused on their main issues, when discussing international issues. Nevertheless, the consistency between their domestic and international political ideas will be analysed, as it cannot be presupposed. It will also be determined whether these ideas are sufficiently similar to allow a theoretical synthesis that can hold its own in the controversies that rage among IR scholars, in particular in comparison to the English School traditions and other liberal theories of IR. It would not be logical to try to establish a classical liberal theory of international relations without ample and explicit reference to the ideas of classical liberal thinkers. Nor would it be logical to try to do so if they have nothing noteworthy 
to say about international relations, or if their views on those subjects are mutually irreconcilable with regard to many or major questions.

An attempt will be made to show that the step of combining the views of four individuals is both valid and cogent. The four thinkers discussed are among the most prominent representatives of the classical liberal tradition and it will be demonstrated that they share a number of views on international relations. Thus, they provide a suitable starting point for developing a classical liberal theory of international relations. The specific claim is that the synthesis of these views does indeed yield a viable theory of international relations in the classical liberal tradition. Obviously, it cannot be expected that all four thinkers have views, let alone the same views, on every issue that comes up in the discussion of international affairs. For the purpose of the thesis, it is sometimes inevitable to apply some selection criterion. One such criterion is the degree of acceptance of a view within the relevant population. For this study, this means that if three of the four thinkers think alike on an issue their view will be taken as the better candidate for representing the classical liberal viewpoint than the dissenting position. This is also in line with the definition of a tradition discussed above. In case of a 'draw', or a philosophical inconsistency in the application of classical liberalism by two thinkers, the classical liberal implications of the idea will be discussed in more detail.

Obviously, a particular stance can only be a part of the IR theory if it is consistent with 'domestic' classical liberal theory, regardless of its degree of acceptance. Indeed, it is logically possible that a majority position fails as an application of classical liberal thought as presented in chapter two. Therefore, it will also be determined whether the elements of the international theory are a consistent application of classical liberal principles. For the sake of detailed and systematic comparison, a similar scheme of presentation will be used for the works of each of the authors, while the presentation of the 'international' aspects of their writings will follow the 'domestic' elements of their theories.

Finally, and to avoid possible confusion: this process of developing an IR theory is not characterised by extrapolation, understood as the extension of lines of thought beyond the currently available facts, in this case the texts of the four thinkers. Rather it is a process of arriving at a synthesis of their expressed views. Hence, the result is fully verifiable and open for 
further argument. The aim of the thesis is not to 'invent' a classical liberal theory, but to present already available information hitherto left largely untouched, or analysed only in non-comprehensive ways.

The method adopted here obviously puts some limits on the claims attached to the outcome. Given the current absence of classical liberalism in IR, the theory presented in chapter seven will be referred to as 'the' classical liberal IR theory, but this is not meant as a claim to exclusive, let alone eternal validity. Future research, for example into the thought of other classical liberals or individual elements of the theory, may lead to changes. As a theory it fully complies to the standards most commonly used in IR and also falls within the definition of international relations theory used here. 


\section{2}

\section{What is classical liberalism?}

Nowadays, the term liberalism can mean one thing or its opposite. This chapter attempts to describe what is generally meant by 'classical liber-

alism'. It may perhaps appear odd to start a thesis on IR theory with a description of 'domestic' classical liberalism. However, this is necessary because classical liberalism is a 'bottom up' theory, which regards international relations as an outgrowth of politics in the domestic, or national, arena. Only by looking at the classical liberal idea 'behind the border', are we able to move closer to comprehending its meaning 'beyond the border' (Sally, 1998: 4-8). Classical liberalism is part of the broad liberal tradition in political philosophy, 'for almost three centuries the political doctrine [that] constituted the principal current of modern politics in Europe and the West' (Manent, 1995: xv). Liberalism is an umbrella concept that covers many ideas (Minogue, 1988), hence the history of liberalism is a history of liberalisms, with classical liberalism as one of its important variants.

Inevitably, this chapter can only present a broad outline of classical liberal thought. It does not serve the purpose of this thesis to reiterate all philosophical discussions on every detail of classical liberalism. That would require a full study in itself. The more modest aim here is to introduce classical liberalism, to distinguish it from other liberalisms and to determine which thinkers are associated with it. In short: to provide sufficient philosophical clarity to enable a fruitful analysis in the rest of the thesis.

The chapter commences with a short historical overview of the liberal tradition to trace the roots of classical liberalism, followed by a presentation of its distinguishing characteristics. To further the conceptual clarity, the closing section will argue to explicitly exclude a number of well known philosophers from the classical liberal tradition. 


\section{A history of liberalisms}

A broad brush history of liberalism starts with the recognition that the age of Enlightenment is generally regarded as the starting point of both modernity and of the liberal age, despite the fact that the label 'liberal' was only coined in the Spanish Cortes in the nineteenth century. Older traces of the liberal doctrine can be detected, particularly in the work of the Stoic philosophers. In the Western world, Judeo-Christianity paved the way for the development of liberal thought, most notably through its emphasis on an individual relation with God. Erasmus and Spinoza were influential in this respect, while the political and social circumstances in the Dutch republic generally have been an example for a lot of early liberal writers. Bernard Mandeville was the first to specifically note the relation between 'private vices and public benefits', while the Hispanic Scholastics also provided input for Adam Smith's economic system (Chafuen, 2003). In England, the pamphlets of John Lilburne and the Levellers were ground breaking in promoting private property, freedom of speech, religion and other ideas now associated with liberalism (Powell, 2000). The development of a coherent political philosophical idea that can be labelled 'liberal' commenced from the late seventeenth century. John Locke is an early and enduring influence (Feser, 2007; Zuckert, 2002), as were the French physiocrats, who influenced the first great generation of classical liberals, the thinkers of the Scottish Enlightenment.

From the late eighteenth century onwards, liberals were also influential in the United States, especially through the writers of the Federalist papers, 'the Founding Fathers', Madison, Hamilton and Jay. In nineteenth century France, philosophers like Say and Constant developed a continental variant of liberalism, later followed by the influential works of Bastiat and in particular Alexis de Tocqueville. In England, the 'Manchester School' liberals Cobden and Bright were influential in practical politics. In other European countries liberal ideas had more difficulty gaining ground (see Bramsted and Melhuish, 1978; and for a critical account Arblaster, 1984).

As shall be discussed in more detail below, between 1860 and the Second World War the original meaning of liberalism changed. Despite 
loosing its prominence, classical liberalism did not disappear. In Britain, individualists like Herbert Spencer fought a battle of ideas with collectivists such as Hobson, Thomas Hill Green and Hobhouse (Machlup, 1969: 119). In the United States, Sumner was an early representative of what is now known as libertarian thought.

While the Anglo-Saxon classical liberal influence waned, the seeds for a classical liberal revival were grown elsewhere. In Vienna, from the late nineteenth century, scientists like Menger, Von Böhm Bawerk and Wieser started to revitalise classical liberalism, at first by the development of economic theory. Later, economists like Von Mises and his student Hayek widened their intellectual scope and also became influential legal and political philosophers. Hayek rejuvenated the intellectual tradition of classical liberalism. As Gray (1982: 21-22) stated during his own 'classical liberal phase': Hayek's system of ideas 'is by far the most promising and compelling research programme for classical liberal philosophy'.

In post Second World War Germany a different group of classical liberals emerged. Academics like Röpke, Rüstow, Eucken, Böhm, Erhard and Müller-Armack became known as Ordo-liberals, after the Ordo Manifesto published in 1936 and the subsequent Ordo annual volume of essays. Röpke was one of the outspoken critics of Hitler, warning against the 'wholesale rejection of all those values an ideals that we subsume under the, admittedly somewhat discredited, expression of liberalism' (Zmirak, 2001: 86). After 1945 the Ordo-liberals had substantial influence on post-war German economic policy (Nicholls, 1994). With the notable exception of Müller-Armack, who favoured a relatively large degree of state meddling in the economy, they were all classical liberals. Eucken and Röpke had a lot in common with the Austrians, for example a firm belief in free and competitive markets, individual choices and a strong dislike for monopolies. Most Ordo-liberals thought that the social welfare state endangered the rule of law and personal freedom (Peacock and Willgerodt, 1989), while international socialism and governmental planning were regarded as Utopian (Willgerodt and Peacock, 1989: 10). It is perhaps no exaggeration to state that they were the last large group of European classical liberals with significant influence on public policy. However, Mises, the dean of the Austrians, was not impressed. In his view, which is slightly exaggerated but not wide of the mark, Ordo-liberalism was not much different from old- 
fashioned Sozialpolitik and the despised Bismarckian Wohlfahrtstaat (Von Mises, 1990b: 240; Hülsmann, 2007: 874-880).

Today, the economists of the Virginia and Chicago Schools are perhaps the most influential classical liberals, while others can be found in think tanks, in academia and in the international classical liberal Mont Pelerin Society (MPS). They share a concern for limited government, constitutional democracy, free trade, private property, rule of law and open franchise. But Buchanan (2005: 52-62) is probably right that, even when taking into account the Reagan and Thatcher era, they often fail to convince the wider public of their ideas. In that sense the free-marketeers are not very good at selling their ideas.

\section{Change of meaning}

In the second half of nineteenth century, the meaning and connotations of the term liberalism changed dramatically, probably the result of a reinterpretation of the core classical liberal ideas by the new or social liberals (Vincent, 1990). Another important explanation for the liberal change is a shift in its own societal role. Classical liberalism appealed mostly in an environment of repressive social structures, when it was an attack on the status quo. In the course of the nineteenth century it became the victim of its own success and developed itself into the status quo. In this way, classical liberals planted the seeds of their own decline and more or less had to make way for social liberalism (Roche, 1976: 8). Later, the classical liberal demise accelerated because of the enlargement of the electoral franchise and the accompanying development of mass political parties divided along socio-economic lines. Also, classical liberal ideas, for example in the field of economics, were simply absorbed by its opponents (Kirchner, 1988: 2-8). From a classical liberal perspective, the social liberals fell for the 'progressive Utopian temptation', characterised by a division between labour and income, abandonment of natural rights and the mutation of free human beings into law-bound citizens (Crombag and Van Dun, 1997: 254-258). Original classical liberal positions were stretched far beyond its natural limit, namely the freedom of the individual. The balance between individual rights and duties evaporated. For example, the idea of equality before the 
law developed into a demand for equality of income. Freedom from coercive intervention led to a demand for positive redistribution and radical interventionist measures (Machlup, 1969: 121-122). Associated with the demand for a more active state is the 'liberal turn to empire', or the idea held by Mill and others of Western superiority and a duty to educate inferior peoples in other parts of the world. These were positions alien to those of the classical liberals (Pitts, 2005: 1-21). Due to the lack of classical liberal influence 'twentieth century liberalism may have been little more than economically smart socialism [...] much opposed to the classical liberal moral ontology' (Van Dun, 2001: 18-19). Some writers insist that this was not so new at all, since the social liberal emphasis on men's rationality and social constructivism can be traced directly to the liberal influence of Kant (Kukathas, 1989: 17), an idea that shall also be discussed below.

Whatever the precise historical and philosophical roots, liberalism became a diffused concept, a situation that lasts to this day. Arguments about the content of the term liberalism continue, both in practical politics and in theoretical discourse. For a lot of people, including many politicians of Liberal political parties, liberalism is a flexible idea that can be used to label many different ideas and policy proposals. Only a small group of scholars and interested lay man are aware of the many differences within the liberal tradition. Sometimes, this leads to bizarre uses of the term 'liberal', certainly among IR scholars.

\section{What is in a name?}

The introduction and proliferation of all kinds of liberalisms has mainly resulted in confusion. Therefore, before introducing the philosophical content of classical liberalism, it is important to shed some light on the many classifications of the liberal tradition found in the literature (see for example Conway, 2004: 10-75).

For example, a very common distinction is between political liberalism and economic liberalism. This categorisation is false, because for liberals it is impossible to separate these two dimensions of human action. Many political decisions have economic effects with direct influence in the individual domain. A state cannot disturb the individual's political 
freedom without interfering in his economic freedom as well, while individual economic freedom is indispensable for achieving political freedom (Friedman, 2002: 7-21). De Jasay introduces another dichotomy, between loose and strict liberalism. Confusingly, his loose variant covers what other writers call social liberalism, yet he names it classical liberalism. The strict variant comprises what others call classical liberalism and libertarianism (De Jasay, 2003). Clearly this pair is too confusing to be of much use.

Some other terms are also regularly used in debates about liberalism. Foremost, the word neoliberalism, mostly seen as grouping rights-theorists and other thinkers who argue strongly in favour of capitalism and a minimal state, like Friedman and Buchanan (West, 1996: 38-39). Neoliberalism is a much abused term, it appears to be the favourite container swear word of people resenting capitalism and globalization (see for example Harvey, 2005). There is not much analytical precision to be gained from the use of this term. Since most writers in the neoliberal category base their thought on old ideas, it does not make much sense to call them neoliberals. In effect, the label 'paleo liberals' would be more accurate.

This leads to the question of the use of the adjective 'conservative' in relation to liberalism. Although Hayek famously argued that he did not consider himself a conservative, it is possible to trace conservative elements in his thought (Gissurarson, 1987) and that of other classical liberals. Conservatives and classical liberals are certainly closer in their thinking than conservatives and other liberals. The similarities are for example the view on human nature, anti-rationalism, the appreciation of tradition, evolving customs and the free market. However, there are also important differences. Conservatism is not individualistic and tends to favour groups and the nation. It also less concerned with the individual natural rights and does not have the same faith in societal change and technological innovation (Cliteur, 2005: 249-286). Therefore, classical liberalism is a better term to use than conservative liberalism. Some prefer the term libertarianism instead of classical liberalism. That is no real clarification, since it has an extreme anti-state connotation in the European context. Throughout this thesis the term classical liberalism will be used for those philosophers that unite around the ideas of scepticism about power, individual rights, spontaneous order, free markets, the rule of law and limited government (Boaz, 1998: xv). 
The most promising of the possible distinctions within liberalism is between social liberals, classical liberals and libertarians. The division is based on a scale of the permitted level of state influence in the life of the individual. Surely, these categories are not cast in iron either nor do they provide hundred percent clarity, but they are by far the more precise definitions available. The term social liberalism will be reserved for the modern variant of liberalism, rooted in the nineteenth century, which compared to classical liberalism calls for a greater role of the state in the life of individuals. Its modern development owes a lot to John Rawls' Theory of Justice, and the subsequent boom in political theorizing (see Kelly, 2005). Libertarianism covers the thinkers who defend individual rights in a strict sense. Some of them favour a minimal state and others, like Rothbard and Hoppe, are anarcho-capitalists, who want to abolish the state altogether. There are different forms of libertarianism (for example anarcho-capitalism, minarchism, objectivism) which cannot all be discussed here. It suffices to note that, in general, libertarians are much closer to classical liberals than to social liberals, although they tend to severely limit or reject the role of the state and have a more rigorous interpretation of individual rights. They feel classical liberals are not consistent enough in their defence of individual freedom and are unable to limit the activities of the state.

\section{Classical liberal philosophy}

In this section, six core elements of classical liberal thought are introduced. Following the historical development sketched above, the main dichotomy and the greatest confusion is between classical liberalism and social liberalism. Therefore, the analysis will emphasise the differences between these two variants. This must not be seen as an attempt to discount the importance of libertarianism. However, contrary to the two other variants, the influence of libertarian thought on international relations theory is very small, if not absent. Therefore, it is not of immediate relevance, despite the challenging ideas some libertarians have about foreign policy. 


\section{The individual}

A central classical liberal idea is that the individual is of ultimate value in a normative political sense. That is not meant to deny that man is a social species, functioning in groups and also largely dependent on others for his survival. Nor are individuals seen as atoms, who egoistically make their way through life, without consideration for others. It just holds the moral, social and political conviction that the individual is the ultimate element in political philosophy, hence not groups, society, the nation, or a particular king or ruler.

However, classical liberals do not idealise man or human nature. They have a realistic view of man's abilities and powers, he is seen as governed by an interplay of passions and reason. Man's intellectual capabilities are not omnipotent, he often makes mistakes or fails to make proper expectations about the future. Contrary to claims of social liberals, socialists or neoclassical economists, individuals are certainly not always maximising their utility in a rational way, on the basis of their perfect knowledge (Sally, 1998: 18-19). Hence an important difference between classical and social liberals is the latter's optimistic appreciation of the rational capacities of man. They have a far greater trust in the abilities of the human mind, in particular when it comes to inventing solutions for societal problems or handling complex social schemes. Classical liberals do not reject the notion of rationality, but rather stress the limitations of the human mind, especially when it comes to planning beyond the most immediate circle of the core family. Reason raises men above the animals and is therefore an important tool for making the best of life (Von Mises, 1996d: 5-7), yet expectations about reason's capacities in societal planning and construction should be kept to a minimum.

Contrary to social liberals, classical liberals believe that man takes life as it comes. Humans are not specifically preconditioned by inborn abilities or an all important personality. Man adapts relatively easily to changing circumstances. If he cannot achieve one goal, he shifts his energies towards other aims. Man is weak in the sense that he is ultimately more guided by his passions than his reason, but he is strong when it comes to mental strength and flexibility (Kinneging, 1988: 17-21). Classical liberals reject the idea that man has to follow a certain path in life, or that an individual 
needs to reach a stage of self-fulfilment to be happy, as for example John Stuart Mill argued. His used the metaphor of the tree, arguing that human nature is by nature required to grow along a certain innate path. As long as individuals are kept free from interference from others, especially the state, human progress is assured. classical liberals feel the individual deployment of creativity will take care of that. They base their normative recommendations on the analysis of man as they perceive how he is.

\section{Freedom}

Both liberal variants regard freedom as prerequisite for the individual to deal with the challenges in life and for societies to blossom. However, they differ on the desired degree of state involvement in the provision of liberty.

Following Isaiah Berlin's classification, classical liberals define individual liberty negatively. Negative freedom is an area of non-interference. It is concerned with opportunities for action, there are no obvious ends to it. The individual is free to use his freedom as he sees fits, as long as the rights of other people are not violated (Galipeau, 1994: 88-90). Social liberals invoke the positive conception of freedom, as they contend that freedom must mean more than paying due respect to the personal domain. Freedom entails that individuals are enabled to make progress in life. Hence, obstacles for individual choice and development must be removed. The resources needed for this must be taken and redistributed by the state. Where classical liberals want protection from intrusion by others, especially the state, social liberals plainly demand state action (Machan, 2003: 13). Social liberals add conditions or qualifications to the concept of freedom, like equality, justice and happiness. Without negative freedom 'human life, both social and individual, withers away'. Following this, classical liberals feel that forced equality fails to provide sufficient room for individual and societal development (Barry, 1987: 4).

For classical liberals, the social liberal ideal of self realisation carries the danger of breaking up the individual into two selfs: the lower self and the ideal self. The ideal is something to strive for, and is often related to a social whole, such as a nation, a tribe or a race. This is a justification 
for some members of the group to coerce others. History shows many examples of rulers who think they are only coercing for the sake of others, to enable them to reach the higher self. According to Berlin (1969:131$134)$, this is a monstrous notion, impersonating people by equating what $X$ would choose if he were something he is not, at least not yet. This is at the heart of all theories of self realisation. History shows that this is the greatest danger of the notion of positive freedom. There are hardly any solid limits to positive freedom, classical liberals maintain, so it is better to take people as they are, instead of what they must become. Liberty may be infringed by the state for a limited number of goals, but otherwise freedom should be as great as possible.

\section{Natural law and natural rights}

The philosophical foundation of the classical liberal claim for individual freedom is based on the concepts of natural law and natural rights, as opposed to utilitarian groundings. A variant of this dichotomy is the distinction is between consequentialist and rights theorists. Barry uses the label consequentialist rather than the more familiar term utilitarian, because 'this is still associated with the attempted derivation of a collective value judgement from individual preferences and therefore commits the fallacy of adding and comparing utilities' (Barry, 1983: 93). Here it suffices to state that rights theorists defend liberty from a moral foundation, while consequentialists mainly defend liberty from an empirical angle. They object to the observable consequences of non-liberal policies and institutions. Consequentialists construct a theory for a free society with little reference to the moral value of liberty. They do not believe that a moral defence of liberty is possible if the person to be persuaded does not already accept liberty as a supreme value. This does not mean that morality as such is not valued, only that it cannot be the most important basis for a defence of liberalism. Instead, consequentialists focus on the (positive) outcome of free markets and limited government for individuals. Deliberate attempts to advance the public good are doomed to end in failure (Barry, 1987: 1218). Consequentialists favour policies that bring the greatest societal good, or greatest satisfaction, to most people. As will be shown in the next section 
this type of utilitarianism differs substantially from classical liberal thought. Nevertheless, classical liberals like Hume and Smith are sometimes erroneously associated with this approach (Haakonssen, 2003: 205).

However, as Van Dun argues, this is wrong and not historical. Classical liberalism was a natural rights doctrine before it became an economic consequentialist idea. It is also a mistake to consider modern libertarianism (Barry's rights theorists) as the natural law mutation of the classical liberal doctrine. Instead, Van Dun defends a distinction between eighteenth century classical liberalism and nineteenth century political liberalism. The watershed practice is the start of the use of positive law and the Rechtsstaat for all kinds of political ends, which often, if not always, violates individual natural rights (Van Dun, 2004: 12-13). A focus only on the consequences of action cannot provide a solid base for classical liberalism. Certain principles, like fundamental freedoms must be beyond calculation of the greatest happiness for the greatest number of people (Machan, 2003: 11-26).

The concepts of natural law, natural rights and classical liberalism are connected, both in their high tide in the eighteenth century and in their demise in the course of the nineteenth century (Van Dun, 2001: 1). In modern times the natural law idea is often refuted on the basis of its presumed religious or metaphysical origins. It is pointed out that this is insufficient for people who are agnostic (Knowles, 2001: 135-136). There are indeed many different theories of natural law, also with religious connotations, yet it is not the purpose of this section to give a complete overview. Classical liberals focus on a specific, modest and non-religious natural law doctrine, that maintains that societies spontaneously develop systems of rules, aimed at protecting personal and property rights (Barry, 2000: 3132). They contend that natural rights are of crucial importance for any society. Human beings are social by nature and for them to be able to act jointly it is required that certain conditions are preserved (Rasmussen and Den Uyl, 1997: 37-59).

Natural law should not be seen in the modern notion of a rationally constructed command, directive or rule (like the Latin lex). The word 'natural' should be taken in its literal meaning, as a rule validated by custom or practice (ius), that ought to be respected. This is not grounded in metaphysics or theology. According to Van Dun, it is the order of natural persons, of living human beings, people as they are born, so to say. This in 
contrast to artificial orders, like Rousseau's, aiming at turning all humans into citizens, who ought to live according to the rules of the state. This would in a literal way 'dehumanise' men, making them an attribute of artificial law, introduced by a small number of people in power (Van Dun, 2003:1-4).

Natural rights are worthy of respect in all but the most extreme emergencies. The natural rights are: life, liberty and property. Governments should respect these rights, or they should lose their legitimacy. Natural rights cannot be 'rights to'. There is no hierarchy between natural people and no hierarchy between one person's natural rights and those of another. No person has a right to another. Respect for the natural law is the right definition of justice (Van Dun, 2000). In the economic context, rights to private property are crucial. For classical liberals there is a strong link between freedom and property. A liberal polity guarantees entitlement to property, as long as it was acquired without violating another person's rights. On a more consequentialist note without property rights people are not motivated to invest their time and labour in, say, the cultivation of a piece of land (Conway, 1995: 10-13), possibly resulting in hunger or mass starvation.

The natural rights tradition should be distinguished from what we nowadays know as human rights. For example, in the French Declaration of Rights of Men and Citizen (1789), the state was just seen as a means to protect the natural rights of man. In the following centuries, under the influence of utilitarianism and other currents of thought, natural rights were no longer limits to state action. In the ideas of social liberals human rights took the place of natural rights. Yet the difference between the two is that most human rights are claims on others that require political action. They are rights to government intervention (Van Dun, 2001: 15-19). In the modern world, there is a tendency to make a right out of every need. Rights are everywhere and everything is a right (Rasmussen and Den Uyl, 1997: 67-68), a development that fills classical liberals with horror. 


\section{Spontaneous order}

Individuals live together, in families, groups, societies and states, which calls for the maintenance of order. Classical liberals refute rationally constructed order and instead prefer the force of spontaneous order, which is seen as the unintended result of freedom in the social, political, economic and cultural realms (Smith, 2006: 3, 5). Social liberals often favour a large degree of government intervention to help create an ideal societal order.

The theory of spontaneous order holds that certain regularities in human affairs are not the product of explicit design, but of spontaneous development, beyond the control of any individual. Ferguson famously called this 'the result of human action, but not of human design'. Until the seventeenth century this order was called 'natural', as it was not consciously planned or thought out. From a modern social theory approach, the theory of spontaneous order is a middle category, between pure natural phenomena and deliberate human intervention. Spontaneous order is not God-given nor a phenomenon acting under strict rules. Instead, it is the result of competition between different possible ways of handling affairs. It is the outcome of trial and error, an evolution of social practices (Hayek, 1967: 96-101).

The best known example of spontaneous order is the free market, but other important examples are customs or conventions. These are defined as 'informally concluded tacit contracts, loosely binding a large number of people', which help humans to make living together easier. Examples are queuing, driving on a certain side of the road, but also more complex conventions like language or the use of money. Some are self-enforced, others need enforcement once they have emerged. All ultimately rely on the fact that the convention serves the interests of enough individuals (De Jasay, 1991: 80-91). Conventions are seen to carry the wisdom and experience of ages, but continue to adapt to new circumstances. More than positive law or any other product of human reason, it is morals, tradition and conventions that are the necessary conditions for lasting progress (Gray, 1995: 82). The institutions in society ensure the development and the maintenance of shared morals, for example family, church, civil organisations, schools and universities, and the market. For classical liberals order is possible and 
preferable with minimal support or intervention from a power wielding authority.

This is not to deny that at some point in time a political order may largely be 'forced', when it is the result of war or other armed struggle. Classical liberals, like Hobbes, may prefer the former to the latter, simply because an imperfect order is better than complete disorder. While it is also possible that some of the rules or conventions of the forced order may be regarded as useful and worthwhile to keep, it is still second best compared to a fully spontaneous order. The chances are slimmer that this 'forced order' guarantees the individual rights, has the same degree of freedom, or that it is sufficiently supported by national sentiments among individuals. Also, in most cases spontaneous order comprises the wisdom and processes of trial and error of several generations.

Opponents of classical liberalism, and sometimes social liberals as well, say that the economic spontaneous order, hence capitalism, results in a loss of morality in society. However, for classical liberals there is a strong connection between ethics and the market, even though they tend to defend capitalism by solely pointing to the superior efficiency and output of the market (Barry, 1987: 7-8). Yet in the classical liberal view, the market stimulates and enforces virtuous behaviour, for example hard work, creativity, mutual trust, capital accumulation, et cetera. Chances of economic success encourage people to work and be innovative. However, it is one of the ideological triumphs of social liberalism that this classical liberal notion has largely vanished (Minogue, 1963: 159-160).

\section{Rule of Law}

In the classical liberal view, most acts of positive law are dictates of pure reason, and cause as much damage to society as rationalist meddling in other fields. However, liberty and the individual domain also depend on protection through laws secured by the state, as not all order can be provided in a spontaneous way. Legal rules should be limited in number and the ones that exist must be binding for everyone in the same circumstances. At the same time the state itself needs to be bound by rules as well, in order to protect individuals against the abuse of state power (Manning, 
1976: 15). With the expansion of state tasks, laws and regulations, classical liberals argue that the original idea of the rule of law must be restored. Governmental power must be curbed, to enable law to take up its original function of protecting individual liberty (Cubeddu, 1993:159-173). Since governments take more power from the people than classical liberals want, they have supported the development of constitutions. These are meant to limit the room for governmental manoeuvre and also make governments accountable to the population. The idea of separating the legislative, judiciary and executive powers of government and arranging their respective power relations in a system of checks and balances is the best defence against the abuse of arbitrary power (Vile, 1998). Of course, this is a weak point in classical liberal thought, because history shows that expansion of state tasks happened despite the existence of constitutions.

Hayek's and many other classical liberals contention therefore is that ultimately only winning over the minds and hearts of those responsible can turn the tide of growing state intervention. Inevitably, winning this battle of ideas is an uncertain and long winded process. Other thinkers, like Epstein aim at reducing the number of legal rules. He states that there are four core legal rules needed for a classical liberal world: the notion of individual autonomy, the right to property, the respect for contracts and the strong prohibition of fraud, or use of force to change the balance of interpersonal relations (tort rule). Needless to say these four rules resemble the natural rights introduced above. But, Epstein maintains, they do not suffice to maintain a stable political order, since they fail to provide for social infrastructure and public goods that help to secure the four rules. Therefore, a form of forced exchange, or the public use of coercion, is needed. This is justified as long as a compensation is supplied to the individual from whom something is taken, in the form of a fair part of the social surplus that is created by public action (Epstein, 2003: 1-64). From a classical liberal perspective the charm of this proposal is that it reiterates the original classical liberal idea about the state (see for example the chapter on Smith), while adapting to modern circumstances. After all, since it is not possible to design a new state from a blank sheet of paper, the modern classical liberal agenda is largely about proposing reform. 


\section{The state}

Classical liberals value the state, but in many respects regard it as the main threat to individual autonomy. 'All the great classical liberals acknowledge that the liberal state may have a range of service functions, going beyond the rights-protection and the upholding of justice, and for this reason are not advocates of the minimum state, but rather of limited government' (Gray, 1995: 70-71). The state is needed to perform certain tasks, which must be limited in number and scope. The most important ones are the defence of individual property rights, through the provision of external defence and internal security (police, legal system), to see to the right workings of the market (some limited forms of competition and regulatory policy) and a limited number of public goods. This last category is notoriously difficult, because it is hard to draw an exact line between public tasks and the private domain. The state often abuses its position ad exclusive rights, classical liberals assert, while it also abuses its control over the money supply. Therefore, many classical liberals, especially those of the Austrian School, argue in favour of the reintroduction of the gold standard, the tying of the amount of money in circulation to the amount of gold (see Callahan, 2004).

Classical liberals reject the collectivist notion that the output of a social system can be distributed according to principles different from those which explain its production (Barry, 1987: 5-6). In contrast, social liberals favour state intervention both on arguments of justice and freedom. These are false arguments according to classical liberals. Provision of some limited forms of welfare is a recognised state task, but it does not necessarily promote freedom. Social liberalism is seen to support welfare irrespective of its bearing upon freedom which causes politics to divert into a technical activity. All societal problems are turned into political problems, which opens the door for large scale state involvement in the life of individuals (Minogue, 1963: 159-161).

Hayek distinguishes three rules for governments to respect:

- government does not claim a monopoly and new methods of rendering services through the market (for example in social security) are not prevented 
- the means raised by taxation must conform to uniform principles and taxation is not used as an instrument for the redistribution of income

- the wants satisfied are collective wants of the community as whole and not merely collective wants of particular groups.

He clearly indicates that these rules are not sufficient requirements, since they did not prevent the gradual erosion of the safeguards of liberal constitutionalism from the nineteenth century onwards (Hayek, 1978d: 111112). Nevertheless, they are important expressions of the classical liberal view towards state action. Much of its work centres around the question of how to keep the state in check, while at the same time ensuring that the state does what it is founded for. However, thus far, no final solution or 'golden rule' has been discovered to limit state action.

\section{Fringe classical liberals}

Besides outlining the most important classical liberal ideas, it is also necessary to explicitly distinguish some writers who are not part of this tradition, even though they are sometimes seen as such. Regularly, philosophers like Hobbes, Bentham and both the Mills are counted among the classical liberals (Conway, 1995: 8), and often Kant as well. However, although a case can be made to include them in the larger liberal tradition, the brief discussions below make clear that important elements in their thought excludes these thinkers from classical liberalism. At best, they may be labelled as 'fringe classical liberals', because a few of their thoughts seem to relate to classical liberalism.

\section{Hobbes}

Hobbes is a prominent example of this erroneous categorisation. Classical liberalism is about individualism and it is therefore no surprise to see Thomas Hobbes sometimes classified as an early liberal (Rapaczynski, 1987: 61-65). In contrast to the collectivist tradition prevalent in his days, 
Hobbes advocates that it is wrong to base political doctrines on a virtuous conception of man, or to reach for human perfection. Instead, it is better to start from the true roots of human nature: the passions (Berns, 1987: 396-401). He bases his political theory on the fact that individuals decide to live together in a state, with the main objective to avoid the war of all against all (Gray, 1995: 9-10).

Yet Hobbes does not care much about individuals or their rights. In his state people live together out of necessity, in fear of falling back to the sorry and dangerous state of nature (Ryan, 1996: 225-237). In order to struggle for life, the individual has the right to do everything to secure his self preservation, like rape, murder, robbing, et cetera. Individuals have a right to those things over which they are able to exert power, including other people. Hence, Hobbes' individual rights lack a relation with justice and natural rights (Van Dun, 2000: 15). As far as ruling the state concerns, Hobbes sees no special value in formally binding governments by the rule of law. Governments may bind themselves by granting rights to citizens and letting them be able to be active economically, which not only generates wealth but also a tax base needed to pay for preserving order and defending the state. He favours a regime where the sovereign has an unqualified right to reign as he pleases, ultimately not bounded by rules. Hobbes' is the first philosophy of sovereign power (see also Strauss, 1950: 192-196).

In his ideal society, the citizens obey the ruler, without believes or passions of their own (Tuck, 1996: xxxiv). To Hobbes, a free man is someone who acts in obedience to the law. The force of the law is such that man voluntarily changes his will, so he obeys freely (Skinner, 1998: 8-10). He believes the state is created by the people themselves, so whatever awful thing it does to them, there is no wrong involved, because they choose it by their own action, so they cannot complain. They authorised it and this means they cannot speak ill of it, revolutionise against it, or accuse it of injustice. From an initial position of liberty, the people find themselves in a situation of complete subjection (Harrison, 2003: 107). Their rights are never safe, as the sovereign can intrude upon them at will, by making new laws, changing existing ones, or sometimes by taking action without the law. The property rights of the subjects never bind the sovereign (Goldsmith, 1966: 200-201). It is clear Hobbes is not a classical liberal, despite his comparable 
view on human nature and the shared recognition that order must precede law. For classical liberals order is perhaps the most important precondition for the good life, but not the purpose in itself.

\section{Kant}

Like Hume and Smith, Kant is an Enlightenment thinker, advocating 'the rise to maturity of the individual', through the public freedom to use it's reason in all matters and circumstances (Brown et al., 2002: 379-381). Kant maintains that history is driven by the emergence of human reason, the great enlightening power, which one day will ensure the emergence of a 'world society of enlightened self-interest, harmony and peace' (Knutsen, 1997: 141). Kant's contributions are most particular in philosophy and epistemology (see for example Scruton, 2000; Guyer, 1992).

Kant is surely an important thinker in the liberal tradition. This shows in his assertion that there is an inherent dignity in individual human beings, and human freedom is at the core of his thought (Franceschet, 2002: 10-53, 67-68). In contrast to the classical liberals, Kant's view on human nature is rather optimistic. Humans are affected by reason, though not determined by it. The more we reflect and think before we act, the better we use our potential to be rational (Williams and Booth, 1996: 78). Also, Kant denounced natural law and postulates pure reason as the grounds for human action (Shilliam, 2006: 215). Kant's epistemological position is explicitly expressed in opposition to the empiricism of Hume. He strongly opposes Hume's contention that reason is 'a slave of the passions', instead he considers reason as an independent source of moral principles (Covell, 1998: 20-21). Kinneging groups Kant in the social liberal camp, because of his belief that the rational capacities of man can overcome the tradition and the senses. Accordingly, an individual can only be free if he is lead by his reason (Kinneging, 1988: 16).

Kant is a strong proponent of the idea of the Rechtsstaat, the state governed according to the rule of law. He claims that justice must be secured through a coherent, universal political order, which therefore must be a legal order. Political action and legislation need to be based on universally valid, public laws. His work centres around the importance of freedom, 
which, like classical liberals, he defines in the negative form. Kant is no utilitarian, condemning the idea that politics should make people happy. His sovereign is not above the law, as with Hobbes, but has to obey to the rules he has given. Nevertheless, his sovereign is placed above the people, because the latter are not allowed to revolt against the sovereign (Reiss, 1991: 1-33). Putting the sovereign (either a person or an assembly) in an inviolable position, must be considered as non-liberal. In practical matters Kant is often conservative and authoritarian. His thought is 'too much tinged by absolutism to be included without reservation [...] in the same school as Von Humboldt, Mill, Spencer, Green and Hobhouse' (Williams, 1983: 125-160). While Kant relates private property to freedom, he holds that the state needs to determine individual property rights by positive law. This is fundamentally different from the Lockean view that the state is external to the concept of property, its only role is to secure the natural rights to property (Kersting, 1992: 348-353). Clearly, classical liberals are fully in agreement with Locke in this respect. Despite some convincingly classical liberal elements in his thought, Kant has to be excluded from this tradition, for reasons that become even clearer throughout this book, when his ideas on international relations are compared to those of the core classical liberals Hume, Smith, Mises and Hayek.

\section{Utilitarians}

The classical liberal credentials of the utilitarians, or Philosophical Radicals, led by Jeremy Bentham and to a lesser extent by James Mill are hardly more assuring. It is better to see their work as a first major critique on classical liberalism. Focussing on Bentham, it must be acknowledged that he supports many classical liberal ideas, for example its economic policies and in legal issues he normally sides with the supporters of individual liberty (Gray, 1995: 28). Bentham's policy prescriptions are probably the reasons why even Friedman sometimes points to him as a fellow classical liberal.

Yet a look at the foundations of his utilitarian theory reveals that order in his ideal society is not the result of spontaneous action, but of design and planning (Barry, 1987: 19). While Bentham never cared to deliver evidence for his theory, he firmly advocates that it is possible to count the 
outcomes of actions in terms of happiness, to compare them and then base a policy preference on the basis of that calculation. Moreover he takes a legal-technical approach towards rules and policies, in the process excluding moral considerations. Thoughts are only wrong if it shows in their practical consequences (Ryan, 1987: 25-31). The classical liberal Scots use the principle of utility to explain the spontaneous emergence of social institutions, or to judge entire social systems. In contrast, Bentham regards utility as the guiding principle for support or rejection of practical policies. Thus, he thinks it perfectly possible to use reason to devise good policy. Hence, by dramatically adjusting the original meaning of the principle of utility, Bentham and Mill transform it into an instrument for interventionism and social engineering (Gray, 1995: 28-29) They distrust inherited experience or tradition and put their faith in the proliferation of encyclopaedic information, which can be used to change society for the better (Fuller, 1987). This latter is precisely the idea classical liberals refute. They combine their appreciation of customs and tradition with trust in societal change, as long as this is a piecemeal process. In the early nineteenth century the general mood was rather classical liberal minded, which is perhaps a reason why the rationalist, dirigiste Bentham and the dogmatic Mill never gained ground with their contemporaries (Thomas, 1979).

Even nowadays, utilitarianism plainly supports policies that classical liberals regard as coercion-based governmental action. The first do not believe that people are better judges of their own interest than 'broadly utilitarian public officials'. Their idea is that those officials are neutral in most cases, do not have their prestige at stake and are better placed to use statistics. This often makes them better placed to judge what is good for an individual. If made democratically accountable, their actions ensure that society benefits from the best possible outcomes (Goodin, 1995: 119-131). The classical liberals do not believe in the neutral, best judgement of public officials, they think it is better to leave it to the individual to decide and bear the consequences of his or her choices. 


\section{John Stuart Mill}

John Stuart Mill is certainly one of the most influential writers in the liberal tradition. He modifies the utilitarianism of his father James Mill and Bentham. He mainly objects to the utilitarian opinion that life is subject to the outcome it produces in terms of happiness. Therefore he adds a qualitative element, stating that some pleasures, mainly of spiritual and mental kind, are superior to bodily pleasures. His classical liberal credentials show in his uncompromising defence of individual liberty and the cases he makes for religious tolerance and individual independence (Ten, 1988: 145).

Yet Mill's defence of liberty is firmly grounded in his utilitarianism. He does not value negative freedom in itself, freedom is only useful if it enables individuals to rise above themselves. Only then they will attain true individuality (Crisp, 1997: 195-199). Mill believes it is worthwhile to aim for higher pleasures, because this results in progress and a better, elevated society. A precondition is a sufficient level of social freedom for all people. A free society is more civilised and better governed, because the pursuit of higher pleasures positively influences the character of the people. The governmental role is not only to produce the maximum of pleasure for its citizens, it must also educate them in preferring the higher pleasures rather than the lower ones. In Mill's opinion, the individual is above the state, but only after receiving the proper education, when he is 'his better self'. Society should provide the conditions for each individual to fully explore and actively use his talents, which is only possible with an active government (Magid, 1987: 784-790). Government is free to act whenever a need is detected. Mill is not so sure that people know what is best for themselves. The poorer class in particular need a helping hand, to prevent them from further harm (West, 1996: 38-50)

It is sometimes maintained that there are actually two Mills, the Mill of On Liberty and the Mill of all his other work. The first Mill is the great thinker of social liberalism, the second one follows in the tradition of, among others, Burke, The Founding Fathers and Tocqueville (Himmelfarb, 1974). This is doubtful, because Mill defends social liberal positions in other writings as well. For example, he makes a distinction between production and distribution in his Principles of Political Economy, with the aim of defending access for individuals to all that society produces. In his ideal 
world, there is plenty of room for society or the state to legally interfere in the individuals's life and force him to become part of society. Therefore, Mill is 'liberationist, not a liberal or a libertarian' (Van Dun, 2001: 12).

Mill also opposes other positions that classical liberals embrace. He has a deep distrust of convention, habit and public opinion, because they obstruct the development of rational education and thinking. On Liberty cannot be considered as an attempt to free men from all doctrine. It is not meant to enable individuality, but only to protect the elevated against the mediocrity of opinion of the rest of society (Cowling, 1990: 104-105). Many writers consider the writings of Mill as the starting point for the classical liberal decline. Mises is especially clear on this point. In his view Mill is the opposite of a classical liberal, he is the originator of the socialist ideas that led to the decline of English liberalism. 'All the arguments that could be advanced in favour of socialism are elaborated by Mill with loving care. In comparison with Mill, all other socialist writers - even Marx, Engels and Lasalle - are scarcely of any importance' (Von Mises, 1996d: 195). Contrary to Ebenstein's claim (2003: 157-162; 2001: 184-192), Hayek is also generally negative about Mill (Hayek, 1948: 28, 110 ). Despite his publication of part of Mill's correspondence (Hayek, 1969), he considered his work as the start of the downfall of true classical liberalism, with its emphasis on social justice, redistribution and the concessions to nationalism and socialism (Gray, 1998: 95-103).

To conclude, it is surely impossible to do more than just scrape the surface of classical liberal thought in the limited length of a single chapter. Nevertheless, the broad outline of classical liberalism has been presented. It is founded in the natural law tradition, and regards individuals of ultimate value in politics. The interplay between individuals, markets, spontaneous order, the rule of law, tradition and morality create the best possible results for individuals and their communities. Classical liberals fear the power of the state, but see an important role for it nevertheless as a provider of security and some public goods, as long as individual negative freedom is respected. In different ways this stands in clear contrast to the ideas of the fringe classical liberals, the social liberals and the libertarians. All the next four chapters begin with scrutinising the classical liberal credentials of the thinker analysed. This is meant to show that they belong to this tradition in the sense of domestic political philosophy, which is of course a necessary 
step to warrant possible conclusions about the existence of classical liberalism as an IR theory. 


\section{3 \\ David Hume and International Society}

Nowadays, David Hume (1711-1776) is most famous for his philosophical work, while his contemporaries were far more interested in his political views. Perhaps that is one of the reasons why his ideas on international political issues are often overlooked or misconceived. Although he never wrote a book on this topic, Hume regularly refers to international relations in most of his works, except his writings on religion (Hume, 1993). His political writings comprise his Essays and The History of England and must be seen as reactions to current debates and reflections on topical issues, as well as attempts to empirically prove his philosophical views (Schlereth, 1977: 108).

IR-scholars have never paid much attention to Hume's ideas on international relations. This is curious, since he also held several official international positions and he fully enjoyed the international character of the intellectual climate of his age (Forbes, 1975: 140). Hume practiced international relations in various capacities. He acquired his earliest diplomatic and military experiences as an assistant to General St. Clair, when he dealt with intelligence regarding the proposed military conquest of Canada in 1746. After a change of orders, this expedition actually turned into a mission in Western France. Two years later he joined the general on a secret mission to Vienna and Turin (Klibansky and Mossner, 1954: xxvii). In the mid-1760s, Hume worked at the British Embassy at Paris, first as a personal secretary to the ambassador, later as secretary to the embassy and chargé d'affaires. He also served as an Undersecretary of State, Northern Department, from February 1767 to January 1768. Most of his writings were published before he gained his main diplomatic experience in Paris, so it is hard to judge how these practical experiences fed into his theoretical 
thought (for more details and a positive opinion on his diplomatic efforts see Mossner, 1980: 489, 533-556). Nevertheless, it is clear that Hume had a great interest in international politics. He not only influenced many of his British contemporaries, but also the political developments in France (Bongie, 2000) and to a lesser extent America. He corresponded with many influential people from several other nations as well. The neglect of Hume means that his ideas are often misconceived by modern IR-theorists.

In this chapter, after a brief characterisation of David Hume as a classical liberal, light is shed on Hume's ideas on international relations. The first step is to illuminate his ideas on the nation, the second to analyse the other IR aspects present in his thoughts. The chapter closes with a discussion of the erroneous and incomplete way IR-scholars have treated his thought and an argument for a reappraisal of Hume's place in IR-theory.

\section{Hume as a classical liberal}

Hume can be considered as one of the founding fathers of the classical liberal tradition (Sally, 1998: 35). The central theme in his work is the exploration of the characteristics of human nature, often within a wider societal context (Merikoski, 1996). His historical and political work is strongly related to his general philosophy. His positions in the latter, for example on the origin of liberty or particular aspects of human nature, are informed by what he perceives as the empirical evidence gained through the description and analysis of the way individuals actually behave (Danford, 1990: 195-196). From this, Hume turns to a normative position, in the form of his political opinions written for his contemporaries to reflect upon, in the belief that political arrangements are the outcomes of human action (Haakonssen, 1994). As one of the first intellectuals who succeeded in making a living solely from his writings, Hume combined scholarly reflection with an active public role.

The individual is the key actor and the main object of study in Hume's thought. The purpose of his Treatise on Human Nature is to find a 'new science of human nature'. In his view the explanation of the principles of human nature is key to explaining everything else (Biro, 1993). Hume contends that in general the passions have more influence on the human will 
than reason does. Passions, or emotions, are the most important explanatory factors of human behaviour. Reason alone cannot produce any action, it 'is and ought to be the slave of the passions' (Hume, 2000: 266, THN). Hume maintains that humans cannot discover ideas or matters of fact by pure reason alone. Rather, the individual mind is full of perceptions, to be divided into impressions and ideas. Impressions are experiences, such as colours and sounds. Ideas are derived from these impressions and should be seen as instruments for such actions as remembering, imagining, thinking. Through the imagination we can combine ideas into more complex ideas, which do not have to be experienced first. But the belief in those ideas lacks a sound basis in one or more impressions, so we cannot be certain about our belief. Consequently, reason is not exclusively capable of delivering truths in the realm of morality, the judgements about right and wrong; neither are divine commands, for that matter. Hume believes moral judgement is grounded in taste and passion. Hence, morality and the laws expressing moral notions to enable a social life originate exclusively in human conduct (Beauchamp, 1998: 10-17). Reason is used to discover, but no to invent, the laws of justice, which Hume argues are equal to the laws of nature (Van Dun, 1994: 277).

Hume has a classical liberal, realistic view of human nature. Human nature is frail and perverse, and it is not possible to keep all men on the path of justice. Some men are simply prone to unlawful behaviour. More importantly, a larger group is often 'seduced from the more important, but more distant interest, by the allurement of the present, though very often very frivolous temptations. This great weakness is incurable in men' (Hume, 1987: 38, E). Of course, people are sensible of the need for justice and order in society, and Hume is not blind to the social condition of mankind. Humans are greatly mutual dependent, hardly any action is performed without other people being engaged (Hume, 1999: 154, EHU). Despite individual differences there is also great uniformity in human nature. He contends:

'It is universally acknowledged that there is great uniformity among the actions of men, in all nations and ages, and that human nature remains still the same, in its principles and operations. The same motives always produce the same actions; the same events follow from 
the same causes. Ambition, avarice, self-love, vanity, friendship, generosity, public spirit; these passions, in various degrees and distributed through society have been, from the beginning of the world, and still are the source of all the actions and enterprises which have ever been observed among mankind' (EHU: 150).

The role of virtue and honour in human behaviour should not be exaggerated, especially not in groups or among the leaders of society. Hume's basis for morality is utility, itself directly connected to our emotions, most notably sympathy, which can be found in all humans and is prerequisite for living together (Gray, 2002: 8-9). While Hume inspired the utilitarians, most notably Bentham and John Stuart Mill (Beauchamp, 1998: 52), his moral philosophy is not utilitarian in the same way. He certainly does not relate the idea of moral appreciation with the greatest happiness principle (Ayer, 1999: 118; Whelan, 1985: 212-213). The later utilitarians use the principle for the recommendation of specific policies, as was discussed in chapter two. Hume does not accept the principle of utility as a basis for normative political outcomes (Miller, 1981: 190), nor would he advocate it as a precise practical formula. The utility of government as an institution finds its basis in the need for individuals to co-operate, which in itself is driven by emotions, most importantly sympathy.

For Hume, liberty and good government are related and natural law is the connecting mechanism. In his science of politics, the focus is on political institutions and forms of government. These constitute the political and societal state in a particular nation (Forbes, 1975: 226, 322). His emphasis is on the importance of institutional stability, because regular or rule-bound institutions withstand the fickle opinion of the day (Haakonssen, 1993: 196).

Generally, positive laws are less important and are also less supported by the people than fundamental laws, commonly referred to as the laws of nature. The laws of nature do not have metaphysical or divine origins, they are human inventions, the results of the human understanding of human nature, marked by self-consciousness and self-interest. The source of the laws of nature for Hume is the principle that ascribes property to occupation and accession of a piece of land. 'Upon the first formation of society, property always follows the present possession' (THN: 327, 75n). 
He contends there are at least three fundamental laws of nature: the stability of possession, its transference by consent and the performance of promises. Keeping promises is especially important for sustaining a stable society. The natural laws are antecedent to the establishment of government, an institution needed in all but the smallest, uncultivated societies living in peace and concord. When societies grow, government is prerequisite to maintain peace and to execute justice, in particular the observance of promises (THN: 346-347). The origin of governments, or as Hume calls it, political society, therefore lies in interest and necessity. In all governments there is a struggle between authority and liberty, neither can prevail in absolute sense over the other. To administer justice, infringements on, for example, the negative freedom of the individual, are needed in order to maintain liberty. In a good society, justice and property rights go together (Hume, 1998: 87, EPM). At the same time governments and rulers are also bound by natural laws and cannot be in total control of society. Good governments are those of laws, not of men, if only because leaders of state are also imperfect humans (E: 37-40, 94). A society is best governed where least freedom is sacrificed. The key indicator for a well governed society therefore is its degree of freedom for the people. Switzerland and Holland are positive examples (E: 403). Liberty is necessary for the perfection of human society (Hume, 1983, V: 96, H).

After a while, the political society itself becomes a source of allegiance for its citizens. Its prime objective is to constrain men to observe the laws of nature. Obedience to the civil magistrate is a prerequisite for the preservation of societal order and concord. This is distinct from the 'regular' obligation to keep promises, which serves to beget mutual trust and confidence among people. When the state ceases to be advantageous, people are no longer bound to submit to it (THN: 347-348, 352-354). The sole foundation of the individual duty of allegiance to government lies in the advantage of its maintenance of peace and order (EPM: 99). His political theory is firmly embedded in his general philosophy. Put briefly, the central connection between the two is Hume's contention that justice and the requirement of obedience to authority are related moral duties or virtues. Individuals are rightly constrained by these moral virtues. In Hume's view, this results in a stable, civilised societal order (Whelan, 1985: 192-196), an aim he supported as he lived in a political world often characterised by 
conflict between parties (Manzer, 2001: 512), most notably the Whigs and Tories (King, 1990: 24-46). Many commentators see Hume as belonging to the Whigs (see for example Conniff, 1978; Miller, 1962).

Hume is no supporter of the original contract thesis. He must be seen as a natural law thinker (Van Dun, 1994). However, Hume acknowledges that at first there needs to be an agreement between people to voluntarily transfer some of their liberty to authority, with the objective of keeping peace and order (E: 468). While conceding to the importance of natural law, he attempts to avoid being perceived as a natural rights theorist. The most important reason is that in his days, the natural rights tradition was strongly associated with the religious influence on politics. Religious demands were disguised as natural rights. Nevertheless, Hume's views are very close to the rights-based tradition introduced in the previous chapter (Haakonssen, 1993: 200-201). Yet it would have been strange indeed for 'Hume the infidel', as he was known by many of his contemporaries, to embrace a position closely associated with the political aspiration of religious leaders.

Hume's contributions to economics are generally praised, although, unlike Adam Smith, he never presented a fully elaborated system. Hume was certainly not the first social philosopher to contribute to economic thought (see for example Clark, 2003). Nevertheless, Hume is a major influence in the transition from mercantilist to classical economic doctrine (Rotwein, 1970: xvi). He must be considered an 'apostle for capitalism', even though that term only became fashionable in the nineteenth century. Yet the phenomena behind it (free production and distribution through markets, private ownership and free exchange) were established practice in his days and were labelled 'commercial society' by Smith (Muller, 2002: xvi-xvii). Hume criticises the mercantilism of his days, instead emphasising the relationship between liberty and economic growth (Skinner, 1993: $222,230)$. Progress in arts is favourable to liberty, because it widens the economic possibilities by diverting labour from the cultivation of land. The demand for luxury will stimulate commerce and industry, tradesmen will acquire property, as will successful peasants. The result is the development of a middle class, which in Hume's eyes, is the best and firmest basis of public liberty. They do not submit to slavery, nor wish to enslave others. They want laws that secure their property, resulting in a government that 
stimulates freedom (E: 277-278). The interests of the commercial class and the landed section of society can be harmonious (Miller, 1981: 133). Without being able to further elaborate on this topic (for more details see Rotwein, 1970), it can safely be concluded that his economics, and other ideas on societal dynamics, generally comply with the spontaneous order characteristic of classical liberalism.

That the best states are free states is a maxim that can be considered one of the major political themes in Hume's work. Freedom should also comprise a whole set of personal liberties, which resemble the classical notions of human rights. A prime example is his praise for the reign of Elizabeth I, where there was a de facto situation of freedom of religion $(\mathrm{H}$, IV: 176-177). Freedom of the press is also a great privilege, he devoted a separate essay to this. Domestic slavery, as found in America and some parts of Europe was dreadful, it denied the slaves humanity and rendered every man of rank a petty tyrant. Hume maintains, it should not be duplicated anywhere else (E: 383-384). He regards liberty as the 'perfection of civil society' and clearly supports such classical liberal positions as personal security under the law, the freedoms of private property and contract, religious belief, and intellectual inquiry and expression, and he believes that political liberty is best preserved by limited, non-arbitrary and representative government under a balanced constitution (Whelan, 2004: 297).

Hence, Hume can safely be considered a classical liberal. He believes in the priority of the individual, has a realistic view on human nature and values liberty, capitalism and non-religious laws of nature.

\section{The nation as starting point}

Hume's international politics commences with individuals forming a society, which is preserved on the basis of sympathy, or the affinity between its members. In political terms a society is called a nation, a country or a state, Hume is not very strict in the use of these terms. The government should be seen as the steering body of the state (Ainslie, 1995: 289-294). The state is a most useful intermediary in the international arena (Schlereth, 1977: 104-105), and in times of conflict, society's survival even depends on a government strong enough to force all capable individuals to join in the 
nation's defence (Glossop, 1984: 54). Hence, the nation is the pivotal international actor in Hume's thought. The principle of national sovereignty was well regarded in Hume's days, and he takes it for granted. A ruler is free to mind his own affairs, without another sovereign having a right to interfere, even when he does not approve of particular conduct $(\mathrm{H}, \mathrm{IV}$ : 159). However, sovereignty is also limited. For example, Hume follows his contemporaries in the claim that the sea cannot become the property of any nation, because it is impossible to take possession of it (THN: 328).

The nation raises feelings or passions that originate in human emotion. An individual might experience negative passions, such as the feeling of humility (THN: 183), for instance when a war is lost. However, Hume puts more emphasis on the several positive emotions the nation stimulates, summarised as 'the passion of national pride'. National pride is caused by direct and indirect positive experiences (THN: 188-189). For example, the beauty of the landscape is a direct source, while indirect experiences come through the pleasures of the senses, like the goodness of a nation's produce, or the pleasure humans get from the qualities of the people they are related to (THN: 200). Among the other indirect sources are the nation's economic well-being (E: 288), or the prevailing intellectual climate, which might positively influence the development of the science of man and human nature (THN: 5), a core concern for Hume and other Enlightenment thinkers.

Hume observes that there are few men to which 'their country [is] in any period of time entirely indifferent' (THN: 79). Once he even wrote [I will] 'joyfully spill a drop of ink or blood, in the cause of my country' (Hume, 1932: 69a, L). Feelings for the nation are, like other passions, strong motivational forces for the conduct of people. It is not possible for anybody to develop a real passion for a foreign country, however nice it may be, since there is a lack of immediate cause of these passions (THN: 218). Or as he puts its when discussing the origin of natural virtues and vices:

'We symphatise more with persons contiguous to us than with persons remote from us; with our acquaintances, than with strangers; with our countrymen than with foreigners. But notwithstanding this variation in our sympathy, we give the same approbation to the same moral qualities in China as in England' (THN: 371) 
Hume does not take this passion to its extremes, as the later (liberal) nationalists would. His perception of the nation is less forceful, the national feeling is not of the overwhelming importance it would be in the nineteenth century (Ainslie, 1995: 306). For him it is clear that 'your country engages you only so far it has a connexion with yourself' (E: 85). Hume's analysis of the differences between nations originates partly in the lively and esteemed contemporary debate on national characters. The major issues were the attempts to reconcile a belief in universal human nature with differences in national characters, and the explanation of those differences. Hayman (1971: 13-14) notes that most participants in the debate did not get beyond generalisations and speculations. However, like for example Montesquieu, Hume has a different approach to the subject.

Hume begins his essay Of National Characters with the warning that only 'the vulgar take all national characters to the extremes'. An individual has several characters, of which the national character is only one. National characters help to provisionally predict someone's behaviour, until more detailed knowledge is available (Ainslie, 1995: 295-296). The national character is the link between generations in a society, and results from a set of fundamental moral and political convictions (Whelan, 1985: 293). Hume states that national characters originate from the interactions among the people in a national society. They are mainly of a moral nature, not the result of physical circumstances. In general, they develop through close ties, communication, the same language and (geographical) borders (E: 197215). Different national characters are historical facts, that among others, entail that different nations need different governments. There cannot be one state or one government, ruling the whole world (Stewart, 1992: 311). Consequently, Hume has no inclination to support a revolutionary overhaul of the world, just as he never endorses the dissolution of the Union of 1707, although he considers it a failure (Pocock, 1985: 138). In general, if there is a misalignment between nations and states, Hume favours a multinational state (Ainslie, 1995: 303-305).

The differences between nations have real consequences in daily life, but they must not lead to a state's international isolation. Hume's basic outlook is internationalist, he values international contacts between individuals and groups of people. For example, when he describes the earliest contacts between the English and the Danes he points at the great advan- 
tages of interaction with foreigners, especially for islanders, as it enlarges their views and cures them of the illiberal prejudices and rustic manners to which they are subject. Comparable advantages are related to the Saxons conquest of Britain (H, I: 103, 161). Also, one of Hume's major views is that the greatness of the state and the happiness of its subjects are strongly related to free international commerce (E: 255, 260), which means mercantilist policies such as export controls are contrary to a nation's interest (E: 308). In general, Hume maintains that while international order can be established within a world of states, this ultimately depends on their mutual co-operation (Whelan, 2004: 224-225). Individuals face a world comprised of nations and have strong feelings for their own country, but there is no point in hiding behind the national border.

\section{Hume and international relations}

Hume's views on international relations proper start pragmatically and empirically. He attempts to reconcile the forces of vice and virtue, the tension between international co-operation and aggression. The borders of the different states are sometimes the outcome of this tension, which Hume takes for granted. As shall become clear, he often takes intermediary positions when judging international politics, which suits a man who considered himself a moderate, and moderation an extremely important value in the bipolar political world of his age (King, 1990: 24-25, 44).

\section{International society}

In international politics, sovereign states are the central actors, which directly follows from the existence of different political societies (EPM: 99). As we shall see below, the balance of power mechanism also 'helps' countries to respect their borders (H, III: 25, 88). Since states are collections of individuals, with their natural tendency to quarrel and fight, human selfishness and ambition remain perpetual sources of war and discord (THN: 362). Therefore, the public good in foreign politics often depends on accidents, chances and the 'caprices of a few persons'(E: 255). 
Neighbouring countries have the duty to maintain good relations, 'suitable to the nature of that commerce, which they carry on with each other' (THN: 362). Like individuals, states are in need of mutual assistance (Glossop, 1984: 51), they do not just interact. Hume is of the conviction that an international society of nations exists, characterised by cooperation, international rules, diplomatic ties and so forth. The relations between nations are regulated by the laws of nations. The most important rules are immunity or 'the sacredness of the persons' of ambassadors, the principle of the declaration of war, the prohibition of the use of poisoned arms and the obligation to treat prisoners of war humanely (EPM: 99).

According to Hume, within the society of nations, the idea of international justice is of great importance. The laws of nations are additions to the laws of nature. The latter are 'the three fundamental rules of justice: the stability of possession, its transference by consent and the performance of promises'. These are duties of princes and subjects alike. The basic interests of men do not change in the international realm, so without respect for property rights, war is the norm. Where property is not transferred in agreement, there can be no commerce and if promises are not kept, there can be no alliances or leagues. The laws of nature have the same advantages in national and international relations. However, there is a difference between the two realms. In international relations, the natural obligation to justice is not as strong as among individuals in a domestic situation. The intercourse between kingdoms is in itself less advantageous than the intercourse among individuals within national society. Without the latter people are not able to subsist, while it is possible to live without being engaged in international relations. In international affairs, the moral obligations between the different rulers are less stringent, 'there is a system of morals calculated for princes, much more free than which ought to govern private persons'. This does not mean that princes can ignore treaties, or that public duties and obligations have less force. 'The morality of the princes has the same extent, yet it has not the same force as that of private persons, and may lawfully be transgressed from a more trivial motive'. There are no fixed rules for such cases: 'the practice of the world goes farther in teaching us the degrees of our duty, than the most subtle philosophy, which was ever yet invented'. Natural and civil justice arise from human conventions and depend on the interest people see in preserving peace and order. The 
smaller the interest, the easier a transgression of justice in international relations is accepted (THN: 362-364).

There are limits to the moral obligation for states to maintain international justice:

'all politicians will allow and most philosophers, that reasons of state may in particular emergencies dispense with the rules of justice, and invalidate any treaty or alliance, where the strict observance of it would be prejudicial, in a considerable degree, to either of the contracted parties' (EPM: 100)

It has to be noted that this quote also shows that the rules of justice can only be disregarded unilaterally in emergency situations. Hume did not propagate a 'realist' disregard or denial of international justice as such. His emphasis is on the importance of international law, although he recognises the looser norms that apply in the international situation. International law has less force than national law, but should normally be respected. As Harrison (1981: 233) points out, Hume maintains that the moral obligation to obey the laws of nations is founded on the utilitarian idea that every nation and its members gain benefit from the existence of those laws. At the same time, it is clear Hume does not expect the evolution of a stable international system of justice, as he takes the outbreak of war more or less for granted (Mackie, 1980: 113-115).

It seems likely that Hume's appraisal of international law and the society of nations developed from his early youth. At Edinburgh University, in his early teens, he was exposed to the works of Grotius (Mossner, 1980: 41-42), but he also read Pufendorf and other natural law writers. He clearly draws on their thought in developing his own political theory $(\mathrm{Oz}-$ Salzberger, 2003: 169). Later in life, in conversations with the ministers of Louis XV, Hume appealed to 'aux droits des gens et à ceux de l'humanité' (Klibansky and Mossner, 1954: xxvii-xxviii), which also shows his appreciation of this central idea in the natural law tradition. Property rights and rules of international law and justice are among the most important issues the natural law writers discuss. They attempt to develop universal rules of arbitration for conflicting interests in domestic and international relations. Hume also believes in a universal human nature and in universal moral norms that support international society. He differs from the natural law 
thinkers in concentrating on descriptive accounts of morality (Beauchamp, 1998: 18-19). Also, Hume famously rejects metaphysical elements in political thought, preferring a strictly empirical approach. In his view, the preservation of international society ultimately depends on the recognition of the value of the law of nations (Glossop, 1984: 46-53), which again points to his utilitarian views on the survival of political institutions.

\section{International balance of power}

Hume's best known essay on international relations is On the Balance of Power, where he discusses the Ancient Greek origins of the balance of power mechanism. Despite some differences with the situation in eighteenth century Europe, he believes the basic idea to be identical. The central aim is to prevent the domination of one big power, so that it cannot execute its own plans without opposition. Prevailing powers can be sure to meet a coalition against them, often composed of their former friends and allies (E: 337). The balance of power system is not magical, but is based on common sense and obvious reasoning, such as the British efforts to maintain a power balance with France. However, Hume is concerned that the wars with France, that sometimes follow from the balancing act, start with justice and even necessity, but are pushed too far, mainly due to obstinacy and passion. For example, the peace of Ryswick was concluded in 1697, but it was offered as early as 1692 , the delay mostly due to imprudent behaviour of the British (E: 323-339).

Hume praises the effects of the balance of power system for both states and their citizens. It is a secret in politics, that adds to a better management of foreign affairs (E: 93). Surely, the system is fragile and prone to set in motion a chain reaction of possibly negative events. Nevertheless, the balance of power mechanism also prevents violent revolutions and conquests of particular states (H, I: 296). The defence of large trading nations like England and the Dutch Republic is not a question of conquest and empire, but of maintaining a balance of power, through alliances and treaties, and the protection of trading routes (Haakonssen, 1994: xxii). Too much focus on domestic affairs leads to the neglect of balancing new and established powers (E: 507). For Hume this is a serious mistake of a statesman. When 
the balance of power functions well, it prevents powerful empires from the abuse of their positions, which, ultimately, would endanger the freedom of individual citizens (E: 337).

Although the mechanism itself is much debated by Hume and his contemporaries, it is an exaggeration to claim that that the eighteenth century was an example of balance of power practice (Black, 1983: 55-61; Sofka, 2001: 147-153). Even so, it is plainly mistaken to hold that Hume is 'among the philosophers that opposed the policy of political-military alliances commonly known as the balance of power' (Schlereth, 1977: 113). Equally wrong are those scholars who consider Hume's defence of the balance of power as an attempt to promote British national interest and its rule of the world (Linares, 1984: 81-82). It is more likely that Hume supports the balance of power to justify the Whig foreign policy of his days, which he sees as 'guarding the general liberties of Europe' (Whelan, 1995: 316-317).

\section{War}

Hume is uneasy about war, although he considers it one of the main institutions of international relations. In contrast to, for example, Machiavelli, he never fully endorses warfare as an instrument of conquest or power politics (Whelan, 2004: 210-211). Hume simply accepts the inevitability of war, not least to keep the balance of power (Whelan, 1995: 318). War can even be justified, for example when a nation threatens the freedom of other states (E: 337).

The concept of justice is helpful when judging (possible) war efforts. Like the international jurists, Hume thinks wars need to be just (Whelan, 2004: 211). However, a degree of justice is not the only Humean criterion needed to accept a war. Commenting on the possible war of the British against Spain and France over the Falkland Islands, in early 1771, Hume also looks into the reasonableness and the sensibility of war, while endorsing the virtue of prudence. Wars commence between two nations, but soon drag in their neighbours, therefore prudent leaders do not lightly risk a war (L: 453). Any war for frivolous causes is wrong (Hume, 1954: 127). 
Hume puts emphasis on the negative sides of war, which are political, legal, and economical. 'The rage and violence of public war [...] is a suspension of justice among the warring parties'. Nations in war no longer consider the principle of justice advantageous. Instead, the laws of war prevail. Any enemy action, however bloody and pernicious, must be countered in a similar way. In these situations, justice literally becomes useless (EPM: 86).

Wars disturb free commerce and create lazy labourers, because they are coerced to produce, instead of relying on their own creativity and the demand of the market. Obviously, wars are expensive, they require increases of the national debt of the warring parties, a development Hume strongly opposes (Stewart, 1963: 194). A sovereign who raises an army, imposes a tax on all people (E: 261-262), and also diminishes the happiness of his subjects (E: 257-259). War limits the freedom of the individual in many different ways.

War might be a part of the national psyche, though. If men are regularly obliged to expose themselves to the greatest dangers in order to defend their country, all ordinary men become soldiers. Whether this is experienced as a heavy tax or a light burden depends on the nation concerned. It is the latter for people who are addicted to arms, fight for honour and revenge, and are not acquainted with gain, industry and pleasure (E: 259). A strong patriotic public spirit may lead to continuous war, which also explains why Hume is hesitant to fully endorse the individual feelings for the nation. According to Danford (1990: 161-168), Hume believes that the rise of civilisation, which depends on the degree of freedom and the protection of property, eventually decreases the desire for war. Yet this does not comply with Hume's view of nature, nor his historical work. He does not distinguish a direct or permanent relationship between the rise of civilisation and a decreasing number of wars.

\section{Empire}

Although Hume died before the American colonies declared independence, he did express his views on questions of empire and imperialism. During most of his life, Hume seems to be morally neutral about the Eu- 
ropean conquests, like many of his contemporaries. Instead, he underlines the enormous importance of the colonies to the world and to Europe in particular. Not so much for the increased availability of precious metal, because the conquest of the West Indies created a surge in the availability of gold and silver in England, which only resulted in inflation. Far more positive effects are the advancements of knowledge, the arts and the industries $(\mathrm{H}, \mathrm{V}: 39)$, the increased levels of commerce, and some social benefits, like the fact that men of inferior rank get the chance to raise a fortune, which would otherwise be untenable. Generally, in England, not only the elite, but also the common people gain from the empire. Hume reasons that if the upper class gets wealthier, they have less reason to repress the people (H, III: 80-81).

From the mid-1760's onwards, the debate on the American colonies gained more public prominence. Hume considers their independence both inevitable and desirable (Stewart, 1992: 308; Letwin, 1998: 116). In 1775, he calls himself 'an American in my principles', and wants the British to leave the Americans to govern or misgovern themselves as they think proper. There is no use in attempting to rule a place so far away, let alone trying to force the American colonists to obey the rules of the English king (L:510). There should be no fear for the independence of the American colonies. Great economic or 'geopolitical' losses are not be expected, apart from some negative influence on navigation and general commerce (L: 514). The only serious detriment is a possible decline in reputation and authority of the English government (L: 511), which is inevitable because a war against the Americans will not be won (L: 512).

According to Pocock, there are also domestic political considerations. Hume is convinced that the empire is a burden, not least financially. $\mathrm{He}$ links the expansion of debt needed to keep the empire with political factions and fanaticism in religious affairs. Therefore, continuation of the North American empire endangers the survival of the nation (Pocock, 1985: 137-139). Despite this open support, Hume does not develop into a major thinker for the American cause. His Tory reputation meets resistance among the Whiggish Americans, although he does exert some influence on American politicians of different persuasions. Franklin visits him several times and corresponds with him from the 1750's onwards. Hume influences Paine's ideas on the origin of government and Hamilton calls him a 
solid and ingenious writer and refers to his work in the last Federalist' paper. In Federalist no.10, Madison is clearly influenced by the essay The Idea of a Perfect Commonwealth, where Hume maintains that a stable republic may cover a large geographical area (Werner, 1972: 439-456).

\section{International trade}

As has been briefly noted in the previous paragraphs, free trade is important in Humean international relations (Haakonssen, 1994: xxi-xxiii, E: $89,92)$. In general, commerce, the greatness of a state and the happiness of its inhabitants are positively related. Overall well-being and prosperity in society empowers the public against the elite (E: 255) and trade and commerce can be sources of opulence, grandeur and of military achievement, as long as they are accompanied by free government and general liberty, as in the British and Dutch cases. Foreign trade increases as it was then called 'the stock of labour' in a nation, and parts of it can be used by the sovereign in the service of the public. The increase in imports and exports leads to more industry, delicacies and luxuries, which are beneficial to the individual citizen (E: 263). On this point, Hume is probably influenced by the French physiocrat Turgot (Robbins, 2000: 151; Fieser, 2005: xii-xiii). Hume strongly rejects the mercantilist' inclination to be jealous of the commercial success of other nations, or the related concern about a positive balance of trade. Trade is a positive sum process, as he attempts to show with rudimentary reference to modern topics in economic science, like regional development and trade, the competitiveness of nations, the infant industry argument and the issue of comparative advantage (Skinner, 1993: 239-245). Concerns about imbalances of international trade are due to jealously and the groundless fear that gold and silver may leave the country (E: 308-309). The increase of richness and commerce in one nation normally promotes the richness and commerce of all its neighbours. It is almost impossible for one state to flourish on the basis of trade and industry, if it is surrounded by states that 'are buried in ignorance, sloth and barbarism' (E: 328-330). Hume was one of the first eighteenth century theorists to almost fully break away from mercantilist thought. This was underpinned by his ability to connect several elements of the economic 
system, such as trade, money, interest and taxes. He did not fully elaborate on his economic insights, which to some observers make them all the more remarkable (McGee, 1989: 197-199).

Foreign trade and international political power are directly related, according to Hume. A richer commercial society is also likely to be a greater military power (Miller, 1981: 125), while the manufacturing sector is a reservoir of labour that supports the military efforts (Soule, 2000: 146, E: 262). 'Law, order, police, discipline: these can never be carried to any degree of perfection before human reason has refined itself by exercise and by an application of the more vulgar arts, at least of commerce and manufacture' (E: 272-273).

Contrary to the impression of many present scholars, Hume does not foresee perpetual peace in a world dominated by commerce. No matter how beneficial commerce is, and despite its occasional peace promoting effects, human nature is not changed by trade. Peace in the commercial age still depends on wise policies and the application of prudence, in order to overcome pride and jealousy, the eternal sources of conflict and war. Trade makes nations richer, which stimulates the development of military technology (Manzer, 1996: 369-382). Hence, in stark contrast to for example the Manchester School liberals of the nineteenth century, Hume did not predict, nor expect, a movement towards peace from free trade. As a matter of fact, nor did Adam Smith (Irwin, 1996: 76; Sally, 1998: 57). In the view of both Scottish Enlightenment giants, trade has its defects and the increased prosperity that results from it, inevitably, also enables rulers to push forward bellicose plans (for a confirmation of this point from a different perspective, see Barbieri, 2005).

To sum up, Hume's opinion of international relations is characterised by moderation and a clear preference for the via media. He combines an internationalist outlook with a firm national base. It is this balance between nationhood and cosmopolitanism that distinguishes him, and other Scottish Enlightenment thinkers, from both mercantilists and nationalists (Oz-Salzberger, 2003: 157-177), and also from many of their English contemporaries (Muller, 2002: 54). Hume cannot be associated with either the realist or Kantian tradition within the English School. He does not endorse ruthless international power politics, nor a revolutionary overhaul of the contemporary world system in favour of the community of man- 
kind. Consistent with his general philosophy he takes the world as it is, and limits himself to recommending small steps for improvements, for example by advocating the expansion of free trade. The Humean world is Grotian, with its international society of independent nations, regulated by basic international laws that supplement the laws of nature. These sets of laws combined are not sufficient for maintaining international order, only the balance of power-mechanism can accomplish that. The occurrence of war is regrettable but inevitable, and sometimes even required to keep the balance. However, Hume does not advocate war for conquest, that falls out of his framework for just and prudent warfare. He holds that some moral requirements are relevant in international relations (Cohen, 1984: 301), but does not apply that to every situation, as is shown by his opinion that not all empire is problematic. Increased international contacts between individuals are encouraged for numerous reasons, in the strong conviction that these will improve the quality of their lives. Perhaps the only really novel insight Hume contributes to IR, is his view that international commerce stands out as the most beneficial form of international cooperation, even though its pacifying effects are limited. The relationship between Hume's politics and his philosophy is his recurrent concern for individual freedom and prosperity. Also, he notes that international politics is conducted by fallible individual humans, therefore his view on human nature applies to political activity beyond the border as well. Given his realistic apprehension of the human capacity, possibilities for the improvement of the international realm are limited to small steps, although the world is not destined for perpetual struggle.

\section{IR theory and Hume}

How should Hume's international relations be qualified from the theoretical perspective of the English School? To provide an answer, his ideas are compared to the three traditions (realism, Kantianism, Grotianism) defined in the previous chapter and to ideas that important IR theorists have about him. As indicated in the previous chapter, this method will also be used in the subsequent three chapters. 
Most international relations academics discuss Hume in relation to his idea on the balance of power (Linares, 1984 ; Nye jr., 1990; Brown, 2001: 107; Jervis, 1992: 718; Knutsen, 1997: 122; Waltz, 1986: 119; Sofka, 2001: 154; Vasquez, 1990: 273-276; Haas, 1953: 456). The large majority leave it to that, which does not do justice to Hume's further views on international affairs. As a consequence of this unbalanced appreciation, Hume is generally seen as a realist, as are Boucher (1998: 145) and Walzer (1992: 76), albeit hesitantly. Even Wight, despite his broad knowledge of the history of ideas explicitly counts Hume among the realists (Wight, 1991: 17, 247, 267; 1995: 168-169), based on the essay on the balance of power and on the distinction Hume makes between justice in the national and international sphere.

Whelan's analysis of Hume as a realist is the most extended argument available and it therefore requires a more detailed discussion. His general thesis is that the thought of Hume and Machiavelli have so much in common that Hume should be counted among the political realists. Here, we shall limit ourselves to the application of this idea to their views on international relations. Interestingly enough though, when he arrives at this point of his analysis, Whelan cannot but underline the differences between Hume and Machiavelli. For example, the latter endorses conquest and the expansion of national territory, while the former mostly distances himself from such practices. According to Whelan, Hume belongs to the eighteenth century law of nations and Enlightenment writers who demand a lawful claim, or a just basis for conquest to be morally acceptable, even though Hume does not always denounce unjust wars in his History. Contrary to Machiavelli, Hume does not relate the greatness of a nation to its military victories or its conquests, but rather to its commercial success. As we have seen above he generally opposes wars that go beyond the need to keep the balance of power (Whelan, 2004: 209-217, 227-229).

Yet, Hume and other liberals are not pacifists, as Whelan rightly notices. There are enough justifications in Humean theory for the use of coercive measures by the state, both in domestic and international politics. However, compared to thinkers like Machiavelli, Hume has a different ethical standard when it comes to issues such as the necessity of political violence, violations of moral and legal principles, betrayal, breach of promises, et cetera. Certainly, Hume cannot be considered a forerunner of Mor- 
genthau's modern international realism (Whelan, 2004: 315). Therefore, Whelan finds himself needing to draw an analytical distinction between 'soft' and 'hard' forms of realism. Hume is mostly associated with the former, which Whelan also labels realist liberalism, and Machiavelli with the latter (Whelan, 2004: 292, 297). From an English School perspective, it is clear that Whelan's 'hard realism' has most in common with the Hobbesian or realist tradition, while the 'soft realism' relates to the Grotian tradition. However, since Whelan appears to be unfamiliar with English School theory, he does not consider classifications other than the well known idealistrealist dichotomy. Perhaps this is due to the wider range of his hypothesis. For the purpose of the current analysis it suffices to note that he makes it very clear that, despite some common ideas, Hume's thoughts on international relations sharply differ from Machiavelli's.

Contrary to Whelan, most IR theorists are not distinguished Hume scholars. Hence, one can imagine why scholars are open to the idea of Hume as a realist. After all, he holds that international rules of equity and justice ultimately depend upon utility; approves of the balance of power system; does not always refute warfare and takes the nation as the central actor in international politics. International justice is not an absolute value to him. However, Hume cannot be taken as a realist. Firstly, he advocates the need for wars that can be seen as justified. Also, he firmly believes in the existence of the international society of nations, although this cannot be equalled to a domestic society, where a government is requisite, in most instances. He is not blind to the anarchical traits of the international society, but is no supporter of ruthless power politics. Indeed, his main appraisal for the balance of power mechanism is based on the insight that it enables rulers and nations to give more attention to creation of prosperity through free trade and commerce, and the consequent positive developments in other parts of society. In this respect it is telling that he states 'Hobbes's politics are fitted only to promote tyranny and his ethics to encourage licentiousness' (H, VI: 153). Hume is sceptical about the usefulness of what he calls 'the philosophical fiction of the state of nature' (EPM: 87-88).

Hume is certainly no Kantian either, as is sometimes argued (see Brown, 2002: 40-41, 47-48). Men are not capable of living in peace for a very long time, and he does not anticipate another international order than the society of states. His appreciation of the strength of national feelings, 
and differences in national characters, prevent him from developing ideas about international political institutions. He asserts that 'there is nothing more favourable to the rise of politeness and learning, than a number of neighbouring and independent [emphasis added] states, connected together by commerce and policy' (E: 119). In addition, he generally distrusts Utopian or revolutionary ideas of an abstract rational nature and rejects the contractarianism that underlies Kant's argument. The idea of world peace is too remote from the 'real world' and from a classical liberal perspective a world government carries significant dangers to individual liberty (Whelan, 2004: 222-223, 297).

While Hume may have been a cosmopolitan in his intellectual and personal life, he was no cosmopolitan in the Kantian sense. He did not elaborate on perpetual peace plans, nor did he reject the international relations practice of his day. Kant called the international legal scholars 'sorry comforters', however Hume was considerably influenced by Grotius and Pufendorf. The importance he attaches to differences in national characters, and the nation as such, prevents him from developing ideas about international political institutions. Also, he has no unrealistic expectations of the peaceful effect of trade. Hume was far too sceptical in his philosophy and too moderate in his politics to contemplate revolutionary ideas.

Hume surely holds that international relations are also a matter of moral requirements. Of the current international theorists Rengger is one of the very few who is aware of this. In a chapter written by him in International Relations in International Thought, he points to Hume's appreciation of the bonds between the nations of Europe, stating that Hume 'is a thinker closer to the "international society tradition" than he is to realism as conventionally understood' (Brown et al., 2002: 383). Rengger does not elaborate on this observation. However, in this chapter we have seen that his contention is far more convincing than other options. Like them (Wight, 1991: 206, 39, 165-166), Hume considers war as a necessary evil, an exception to the rule of peace, but sometimes a prerequisite for attaining international justice where there is no political superior. International society is a true society, with the balance of power a useful and justified mechanism. Therefore, Hume should be seen as a Grotian (also see Van de Haar, 2008). 


\section{4}

\section{Adam Smith, War and Commerce}

Unlike Hume, Adam Smith (1723-1790) has always been associated with international relations, particularly through his pleas for free trade. Yet, among his contemporaries he was best known for his moral theory. Smith was an academic and writer most of his life, although he became a Commissioner of Customs in his last years. He had limited personal international experience, consisting solely of a long trip to France and Geneva, as a tutor to the Duke of Buccleugh (West, 1976; Buchan, 2006).

However, his views and interests were by no means provincial. Like Hume, Smith has more to say about international politics than is commonly understood. He frequently discusses the situation in Europe, the (American) colonies and also displays knowledge of Asia (Lockwood, 1964; Sen and Rothschild, 2006). His views on issues like national defence, war and empire are sometimes discussed by Smith-scholars, but hardly by IRacademics. With the notable exception of an article by Andrew Walter, there are no comprehensive analyses of Smith's ideas on international affairs. This is curious, given the fact that sometimes lengthy remarks on international issues are found in all his work, with the exception of Essays on Philosophical Subjects and Lectures on Rhetoric and Belles Lettres.

\section{Adam Smith and classical liberalism}

Adam Smith is widely, and rightly, seen as the quintessential classical liberal, even more so than Hume. His view on human nature is realistic. At the centre of his thought is the conviction that man has several natural rights to liberty, that protect him from physical injury and give him freedom to, 
for example, trade or freely engage in marriage (Smith, 1982a: 8, LJA) ${ }^{1}$. The most sacred laws of justice are those that protect life and person, property and possession and the personal rights of an individual (Smith, 1982b: 82-84, TMS). These rules are constitutive for Smith's ideal, the system of natural liberty (Ross, 1995: 54), a concept that directly originates from natural law (West, 1996: 4-5). In it, 'every man, as long as he does not violate the laws of justice, is perfectly free to pursue his own interest his own way, and to bring both his industry and capital into those of any other man, or order of men' (Smith, 1981: 687-688, WN). People who refrain from doing injustice to others, are entitled to the same treatment themselves (TMS: 82-84). However, he does not always favour equality in a social sense, differences between people in society are endorsed and proper behaviour entails maintaining one's own rank and dignity in society (TMS: 38). People are different, so there will be differences between people even when the system of natural liberty is in place.

Freedom comes with responsibilities. Following the Stoics, Smith thinks every man has a duty to look after himself. The individual is in a much better position to judge his personal situation, since others do not feel his pleasures or pains with equal intensity (TMS: 219). Therefore, to regard one's private happiness and interest are often very laudable principles of action (TMS: 304). Like Mandeville, Smith asserts that individual action is the foundation of society. Humans are impelled to action because they feel the urge to satisfy their needs (Infantino, 1998: 15).

Like Hume, Smith cannot be regarded as a utilitarian in the Benthamite sense (Macfie, 1967: 158). Concern for the increase of aggregated human happiness is not part of his thought, he refrains from utilitarianism when explaining the origin of moral rules, or when judging individual action in everyday life (Haakonssen and Winch, 2006: 380-388). He does give consideration to utility when evaluating social, political and moral systems and phenomena (Campbell and Ross, 1981: 73; Shaver, 2006), but, like Hume, only to explain the continued existence of these institutions. Smith is a natural law thinker through and through (Teichgraeber, 1986), and thinks the general rules of morality are ultimately founded

1 There are two known reports of these lectures, both included in the Collected Works. The first (version A) is a report of 1762-63, the second (Version B) dates 1766. Both appear to be genuine. 
on what in particular situations our moral faculties approve or disapprove (TMS: 159).

Since man is generally a weak judge of the propriety of his own behaviour. This is a perpetual source of societal disorder. Therefore, Smith introduces the imaginative 'impartial spectator', meant to serve as an additional personal moral guide (Raphael, 1975: 96). The idea behind it is that people learn from observing the conduct of others. This will lead them to form opinions about right and wrong behaviour, which then can be applied to themselves (TMS: 158-159). Although often portrayed as such by opponents, Smith is not 'the great defender of egoism'. Instead, sympathy between people is the central virtue in his moral system, as is clear from the opening sentence of his first book:

'how selfish soever man may be supposed, there are evidently some principles in his nature, which interest him in the fortune of others, and render their happiness necessary to him, though he derives nothing from it except the pleasure of seeing it' (TMS: 9).

For Smith and other writers of the Scottish Enlightenment sociability is of central importance in human relations (Smith, 2006: 37). Humans are not atomistic, their nature is inherently social (TMS: 41). Accordingly, to restrain the selfish sentiments and to indulge in benevolent actions is the perfection of human nature, as it brings harmony of sentiments and passions among mankind (TMS: 25). The origins of benevolent action are the convivial passions, such as generosity, humanity, kindness, compassion and mutual friendship (TMS: 39). Smith adds: 'Kindness is the parent of kindness' (TMS: 225).

To maintain society, a legal system is also of crucial importance, because individual members will do injustice to others that must be avenged (TMS: 88). Just like the market economy, legal institutions and laws are the result of spontaneous order, they are also the unintended consequences of individual behaviour in pursuit of personal or social goals (Otteson, 2002: 259). This means they develop slowly, through adaptations to changing circumstances. Ultimately, Smith hopes, this accumulation of wisdom through the ages will lead to a legal system that represents the wisdom and judgement of the impartial spectator (Evensky, 1995: 206-213). Conse- 
quently, Smith's opinion on positive law is not very favourable. It may serve as a record of the sentiments of mankind in a particular time and place, but should not be regarded as an accurate image of the rules of natural justice (TMS: 341).

The importance of Smith for the development of economic science is often exaggerated (Rothbard, 2006b: vii). Also, the assumption that there was no economics before the publication of The Wealth of Nations, is clearly erroneous (see for example Clark, 2003; Viner, 1930). Smith himself acknowledged the influence of Turgot. Nevertheless, Dugald Stewart (1982: 320), Smith's first biographer, defends the originality of his economic thought, by pointing out that his doctrines were already put forward well ahead of the French, in his lectures of the early 1750s. A modern scholar argues that Cantillon, Quesnay, Steuart and Turgot are authors of systems of political economy that are at least on a par with Smith's. However, his intellectual superiority rests on the integration of manufacture in the theory of production and allocation, the firmly established place of capitalism in his theory and the scope of his political economy as a distinct project, while remaining related to the other human sciences (Aspromourgos, 1996: 165166).

This last point is of most importance here. Smith's economics starts from 'the inherently human propensity to truck, barter and exchange one thing for another', leading to a division of labour, which is both spontaneous and advantageous to society (WN: 25). Smith's famous example is the unintended consequences of the motivation of bakers, brewers and butchers. They tend to their self interest, which unintentionally leads to a situation where essential products and services become available to other people. Perhaps less noted is the moral lesson in this example. Smith warns that people should not make themselves dependent on the good-will and humanity of others. Indeed 'nobody but a beggar would choose to depend upon the benevolence of his fellow citizens' (WN: 26-27, LJA: 347-349). Commerce stimulates the gradual introduction of order, good government and the liberty and security of individuals, as commercial success depends on virtuous behaviour, like faithfulness, punctuality or fulfilling agreements (LJB: 538).

For Smith, economic freedom is an end in itself (Rothschild, 2001: 223), because it enables individuals a certain degree of independence. Gov- 
ernment's role is not to create equality among people, but to ensure the equal provision of the conditions that are needed to reach independence (Fleischacker, 1999: 182). To serve the general interest, a sovereign has to perform three duties. First, protecting society from violence and invasion of other independent societies. Second, protecting, as far as possible, every member of society from the injustice or oppression of every other member, by protecting his property rights. Third, constructing and maintaining certain public works and public institutions (WN: 687-688). This last category consists not only of the protection of merchants who deal with barbarous nations, but also the provision of basic education (WN: 724731), which is a point for divergence of opinion among classical liberals. Important here is that Smith sees many dangers involved in foreign trade. It also makes clear that classical liberals have always regarded the state as a much needed service provider.

Smith does not analyse political systems in much detail, nor does he argue for a particular type of regime (Griswold, 1999: 301). In public affairs, he mainly distinguishes between two kinds of rulers, the good 'man of public spirit' and the bad 'man of system'. The man of public spirit is benevolent, shows humanity, respects the established powers, as well as the rights and privileges of individuals and groups, which together form the constituent parts of society. The man of public spirit tries to persuade with words, and will never 'use more violence against his country than he would against his parents'. His policies accommodate the established public customs and practices. The man of system is his dangerous adversary, who has a striking resemblance with the later Marxists, socialists and other collectivists. He is full of himself and advocates alternative models of society and promises beautiful futures, after societal reform. These shining alternatives tend to intoxicate his followers, and feed into their fanaticism to overthrow the status quo. He

'seems to imagine he can arrange the different members of a great society with as much ease as the hand arranges the different pieces upon a chess-board. He does not consider that the pieces upon the chessboard have no other principle of motion besides that which the hand impresses upon them; but that, in the great chess-board of human society, every single piece has a principle of motion of its own, altogether different from that which the legislature might chuse to impress upon it (TMS: 234). 
Surely,

'some general and even systematic, idea of the perfection of policy and law, may no doubt be necessary for directing the views of the statesman. But to insist upon establishing, and upon establishing all at once, and in spite of all opposition, every thing which that idea may seem to require, must often be the highest degree of arrogance. It is to erect his own judgement into the supreme standard of right and wrong. It is to fancy himself the only wise and worthy man in the commonwealth, and that his fellow citizens should accommodate themselves to him and not he to them' (TMS: 234)

Therefore,

'Nothing tends so much to corrupt and enervate and debase the mind as dependency, and nothing gives such noble and generous notions of probity as freedom and independency' (LJA: 333)

A better expression of Smith's classical liberal credentials is hard to find. In these three quotations we find his anti-constructivism, anti-rationalism, anti-authoritarianism and his belief in individual liberty.

\section{Adam Smith and IR}

Adam Smith's ideas on international relations offer a fairly complete theory, based on his domestic politics. He has some elements in common with Hume, but also holds several different positions.

\section{Nation}

Like Hume, to Adam Smith the nation is an object of human passion and the state is the most important actor in international affairs. The honour of the nation is part of the honour of its citizens. National history is a source of sometimes negative, but more often positive emotions. Patriots who lay down their life for the safety or the glory of society, are laudable (TMS: 227-228). Smith distinguishes two principles for the love for the 
nation. First, the respect and reverence for the current form of government or constitution. Second, the earnest desire to establish the safety, happiness and general welfare of fellow-citizens. In peaceful times, these principles easily co-exist, he holds, perhaps a bit too optimistically. However, in times of discontent this may change. Then, only wise patriots are able to decide what is best (TMS: 231-232). Of course, from a classical liberal perspective this position also has its problematic sides, as it grants the ruling elite a lot of authority, which can easily be abused.

Contrary to the Stoic views that otherwise influenced him, Smith asserts that the notion of world citizenship is at best a very loose idea. The ties between smaller social units are stronger and also more important. It is natural for humans to put family, friends and the nation first (Raphael and Macfie, 1982: 10), normally also in that particular order. There is a difference between the love of our own country and the love for mankind. Both sentiments exist independently of each other. Smith thinks countries are loved for their own sake, not as part of 'the great society of mankind'. If there is such a society at all, it is best served by individuals who direct their love towards a particular portion of it. This is within the sphere of man's abilities and understanding, and in line with the natural system of human affections (TMS: 229). People simply have stronger feelings for those who are near to them. He gives the example of a terrible earthquake happening in China. People are shocked to learn about such a natural disaster, but they quickly continue with their own lives. They are far more concerned by much smaller events which directly affect them (Smith, 2006: 38). Smith also feels a man is always displaced in a foreign country, no matter how polite and human the local people are (Smith, 1987: 108, C).

Smith is a little unbalanced in his appreciation of the differences between nations and national characters, a debate he is far less engaged in than Hume. Usually, he is neutral and factual. 'The different situations of different ages and countries are apt [...] to give different characters to the generality of those who live in them'. In all societies there are general and natural rules and practices of propriety, just as there are plain principles of right and wrong, in every country, which keep society together (TMS: 204, 208-209). Sometimes, Smith shows a strong national prejudice, for example when he directly relates national interest and national characters. Nations of manufacturers, like Britain and France, naturally breed people 
that are frank, liberal and good fellows. The inhabitants of Holland and Hamburg, trading nations that can only grow rich through parsimony and privation, are characterised by narrowness, meanness and a selfish disposition (WN: 668). Yet he also makes a lot of positive remarks about the Dutch way of life in other parts of his writings. Geographical circumstances are also important for the differences between nations. Smith asserts that Africa, parts of Asia and herding peoples like the Tartars have always been barbarous and uncivilised, mainly due to a lack of basic conditions for economic and cultural development: difficult conditions for defence, lack of fertile land and bad access to communications by land or waterways (Skinner, 1979: 75).

That Smith regards the nation as the most important actor in international relations also has a basis in religion. Surely, universal benevolence and practical good offices can seldom be stretched across the nation's borders. At the same time, the idea of good-will knows no boundary and may even embrace the immensity of the universe. This can only be a source of happiness if people recognise that God directs all movements of nature. According to Smith, a wise and virtuous man is at all times willing to sacrifice his own interest to the public interest of his country and in its turn that country should sacrifice its interest to the interest of the great society of all sensible and intelligent beings, of which God himself is the immediate administrator and director. The administration of the great universal system, the protection of happiness of all rational and sensible beings, is the business of God and not of man. For humans, the duty is to mind the happiness of relatives, friends and country (TMS: 235-37). For Smith, cosmopolitan unity is clearly beyond human ability and is therefore not a serious political goal.

\section{International society}

Smith's scepticism about the prospects for a transnational or cosmopolitan order shows in his critical opinion of the binding force of the laws of nations. Yet at the same time, he values attempts to create binding rules at the international level, and distinguishes the existence of (a rudimentary) international society, at least in a European context. 
Smith recognises the existence of rules and practices at the international level. The laws of nations are 'the different regulations that subsist betwixt different independent states, with respect both to the mutual intercourse betwixt them in time of peace and what privileges may be granted them, and to the effects of the success in war and what is permitted as lawful in the time that war is waged betwixt different nations'(LJA: 7). Smith concludes the Theory of Moral Sentiments with the observation that Grotius was the first to systematically describe the principles that of the law of nations. The Rights of War and Peace is 'the most complete work that has thus far been written on that subject' (TMS: 341-342). The laws of nations encompass the demands which one independent nation might have on another, the privileges of strangers and the description of the proper grounds for war (LJB: 399). International law cannot be as precise as private or public law. Quoting Grotius, Smith asserts that there are hardly occasions when a regulation is agreed with the common consent of all nations and is also observed at all times (LJB: 545). In a passage close to modern realist thought, he argues that independent and neighbouring countries, lacking a superior, live in constant fear and suspicion of one another. Every nation expects its own downfall when the neighbouring countries rise in power. The laws of nations are 'often very little more than mere pretension and profession'. The laws of justice are hardly ever observed in war and negotiation. Truth and fair dealing are often disregarded and treaties violated. Worse, that violation is hardly ever punished. Instead the 'ambassador who dupes the minister of a foreign nation is admired and applauded, even when only small interests are involved. This often derives from "the noble love of our own country"' (TMS: 154, 228).

At the same time, Smith has a high regard for international institutions, which are important to defend the general welfare of the individuals of a particular country, not least because they facilitate commerce. Despite his pessimism about the binding force of international law, he argues that the sovereign still has the duty to maintain the institutions of international society, in particular diplomacy. In countries where building permanent structures to protect trade is not an option, permanent representatives should be posted. Even in places like Constantinople and Russia, where he sees no obvious political reasons to maintain diplomatic ties (WN: 731733). The immunity of diplomats should be sacred and protected, and 
their homes 'asylums for offenders'. Ambassadors stand outside the system of justice of the country they live in. They should be exempt from taxes, just like the sovereign they represent. In order not to offend the hosts, diplomats should be cautious in exercising these rights and involvement in conspiracies against their host country is a good reason for imprisonment. Smith thinks diplomats are important for keeping international relations as smooth as possible, and they also provide good information about the country in which they are posted. He disagrees with Grotius, who considered ambassadors 'spies in residence'. Smith argues that the increased levels of commerce make it impossible to preserve peace 'for a month', without permanent representatives who sort out the day to day frictions (LJB: 551553). Non-diplomatic foreigners should be allowed to settle and enjoy the protection of the laws in the country, because they bring prosperity, commerce and improvements in arts (LJA: 307-309).

Smith regards neutral nations as the impartial spectators in international society. Contrary to the realists he argues that the basic rule of justice concerning them is that they have done no injury and therefore should not suffer injury. Their neutrality should be respected, and they should be able to trade with both sides in a conflict (LJB: 550). Unlike the impartial spectator in personal ethics, neutral nations are less relevant to the warring parties who feel strong hostile passions towards the enemy. An attempt to please an impartial spectator does not serve any purpose for them. Therefore neutral states are not a disciplinary force to foster justice in international relations.

Order in (European) international relations comes through the balance of power, according to Smith (Haakonssen, 1981: 179). Smith does not write much about the balance, with the exception of a few historical passages (LJB: 552-553). Yet it is clear that he considers it an important instrument for peace and tranquillity. The prime, if not the sole, motivation for rulers to maintain it is their concern for the national interest. From a domestic politics point of view, international stability is a conditio sine qua non for all the different groups in society which want to keep to their positions. Therefore, the balance of power is the most extensive form of public benevolence statesmen can offer (TMS: 230-231), since it provides both international and national order. 
Smith is a critic of many contemporary international practices. International jealousy is one of his prime targets. It is wrong for the French and the British to envy each other's happiness and prosperity, the cultivation of land, advancements in arts, manufacturing or culture, or the increase in commerce and even the security and number of ports. The only good reason for suspicion is the increase of the neighbour's naval and military power (TMS: 229). The animosity between France and Britain is a good example of lost opportunities, even though being neighbours means that 'they are necessarily enemies' (WN: 494-496). For non-neighbouring countries a state of tranquillity is easier too achieve, because natural prejudices and hatred seldom extend beyond immediate bordering countries (TMS: 229230). Trade is helpful, because 'the more we trade with our enemies, the better we shall be able to defend ourselves against them'. This may make international relations more a matter of diplomacy and less an area where the military dominates (Haakonssen, 1981: 179-180). Therefore international society is able to develop, but it must be noted that Smith does not argue that trade promotes peace in a more lasting or fundamental way. The different states remain enemies, and the balance of power is the main mechanism for ensuring international stability.

Despite the many differences between countries, Smith repeatedly treats 'Europe' as a coherent economic and cultural unit. He writes at length about the 'Policy of Europe', the good and bad traits in the economic policies in a range of states, including England, Scotland and countries on the Continent (WN: 135-159). When he discusses the relationship with the American colonies, he speaks of 'Europe considered as one great country' (WN: 591). In the context of a discussion on restrictions of the corn trade, Smith argues that when all European states implement a liberal system of free trade, in an economic sense they will become like provinces of a great empire. The larger the political entity, the easier the communications over land and sea, which would result in the absence of economic scarcity and the sure disappearance of famine. Smith notes that this vision is nowhere near implementation, as these trade restrictions in corn are in place almost everywhere (WN: 529-539). The resemblance of Smith's ideas with the current European Union is of course striking. He assumes there is a common denominator among the European nations, although it would be anachronistic to see an argument for political unity in it. However, it may 
serve as counter-evidence to those modern commentators who argue that the EU can never be more than a loose trading area because of its alleged lack of a common cultural base.

\section{War}

War is a normal feature in international society, if only because the idea of human sympathy cannot be stretched indefinitely (TMS: 36). One of the least noted aspects of Smith's thought is the importance he attaches to defence, military organisation, patriotic and heroic military virtues (Winch, 1978: 105). However, he never blindly endorses war and like Hume broadly remains within the just war tradition, like Hume. Perhaps most remarkable is Smith's emphasis on the relationship between trade and conflict, given his present day association with the opposite idea of free trade as promoting peace.

Smith clearly shares in the Grotian natural law heritage. He does not think it justified to start a war without a proper, morally justified ground. In general, Smith defines justice as 'the abstention from injurious behaviour to others', which is also a good way to regulate the relations between strangers (Haakonssen, 2006: 6). In this way the just war tradition can be seen as his application of justice in the international context. War needs 'the same proper foundation as a law suit before a court of justice'. As will be discussed in chapter seven, Smith uses the regular Grotian examples when discussing justified violent action, such as the violation of property rights by another state, when another state kills one's subjects or imprisons them without recourse to justice. In such cases it is the duty of a government to protect its citizens. This is also the case when a nation continuously fails or refuses to repay its debts, or if it violates the terms of a contract in a different way. 'Every offence of the sovereign of one country against the sovereign of another, or of the sovereign against the subject, or the subject of one country against the subject of another, without giving reasonable satisfaction, may be the cause of a war' (LJB: 545-546). Retaliation and preventive action are justified in clear cases of conspiracy, or when territories are threatened (LJB: 546-547). There should also be rules in war. Foreign captives are entitled to a humane treatment and Smith highly 
regards the practice of exchanging prisoners after a war, with the losing state paying the balance. In the case of a conquest, the leaders of the territory may be replaced, but the customs of the conquered people must be left unaltered. It is also good that ambassadors remain at their post during hostilities. Somewhat surprisingly and while not much is known about his religious feelings (Haakonssen, 2006: 13-14), Smith gives most credit to the Pope for establishing these rules, in his [secular, EvdH] role as the common Father to all humans (LJB: 548-550).

In the context of international justice, Smith is an early critic of international law. The laws of nations are not congruent with the rules for just war, because they fail to defend the most obvious rule of international justice: that only the warring party receives punishment. In ancient times, all people were involved in the decision of waging a war (LJB: 407) and therefore it was justified that they all suffered in war. In contrast, most unjust wars are fought on account of kings and sovereigns, who engage in imprudent wars and foolish peaces, like the one in Utrecht (LJA: 326). Innocent people pay the highest price for both, they suffer for the really guilty by having their land and houses seized, or by getting killed. This practice fully complies with the laws of nations (TMS: 155, LJA: 200), yet has no relation to justice. Smith therefore disagrees with his teacher Hutcheson, who thought that the people are indeed indirectly accountable through their support of their government (LJB: 547-548). This is actually still a relevant issue within just war debate (see for example Cornish, 2007: 196).

For Smith, besides questions of justice, major disadvantages of war for Smith are its costs and the waste of resources involved (Oncken, 1877: 141; Fleischacker, 2004: 254-255). War and the preparation for war are the greatest amounts of public expenditure (WN: 821). For example, the four wars against the French, in 1688, 1702, 1742 and 1756, resulted in a British national debt of one hundred and forty five million pounds. In addition there are losses that are related to missed economic opportunities (WN: 345). Surely, some parties also benefit from a war. The Italian cities Venice, Genoa and Pisa made fortunes from rendering services to the armies of the crusaders. Accordingly, 'the most destructive frenzy that ever befell the European nations, was a source of opulence to these republics'(WN: 406). Wars are normally paid for by contracting debt and 
if the dues are paid back this practice is in line with sound economic policies (WN: 909-910). However, politicians spend public money rather than repay debts, therefore Smith proposes that wars should be paid by taxes that are immediately felt by the public. This would surely diminish the desire for war and limit their length (WN: 920, 926).

However, not all is bad about war, especially when it comes to personal character building. Despite the atrocities involved, Smith regards warfare the noblest and complicated of all arts. (WN: 697). A man of spirit and ambition will see in a foreign war a chance to gain fame and honour, despite all the chaos and bloodshed involved (TMS: 55, 65). In war, men learn to overcome the fear of death associated with weak people. Military men develop the important virtue of self command, the most distinguishing feature in the character of the favourite heroes of all ages. It is the virtue from which all other virtues seem to derive (TMS: 239). For example, soldiers are prepared to die in fights in far away places, which is certainly not in their personal interest. This sacrifice stems from the strongest passions of public spirit, the senses of duty and propriety (TMS: 191-192). When a nation becomes opulent, the general warrior spirit fades away (LJB: 411), because rich countries do not call upon their citizens to fight a war. Instead, foreign mercenaries are hired (LJA: 238-239). This is a negative development, which he proposes to partly redress by public education, which not only encourages order, decency and respect for the government, but also a martial spirit (West, 1996: 26-27). Again, many modern classical liberals disagree with Smith on this point, underlining the danger of governmental abuse.

Smith writes extensively about military organisation, strategy and history. $\mathrm{He}$ is an active participant in the contemporary public debate on Scottish defence (Winch, 1978: 103-120). In his view, raising an army is the first duty of the sovereign. In an advanced society the army is small in number and should be manned by specialists and professionals. This is due the invention of fire arms and general improvements in the art of warfare, as well as the principle of division of labour (Smith, 2006: 94-96). 'The wisdom of the state' renders the trade of soldiers particular and separate from other trades. Unlike many of his friends, he is a firm supporter of standing armies. To organise military force through militias is not preferable. These are non-permanent and demand people with different pro- 
fessional backgrounds to be soldiers as well. National defence should not be a matter of part time soldiers. Militias are inferior to standing armies (Hoogensen, 2005: 109) and may only serve as reserves, with primarily an educational and moral role. They should be restricted to the provision of semi-skilled and highly motivated military assistance, as a sign of civil duty and virtue (Neimanis, 1980: 29; Sher, 1989: 261).

Contrary to Fitzgibbons' assertion (1995: 122) Smith prefers the establishment of standing armies in civilised nations throughout his career (see also Skinner, 1979: 213). Letwin may be right to point out that history shows that armies are dangerous to individual liberty and that Smith is sometimes exaggerating his case about the benevolent sides of a standing army. This is surely not a sound enough basis to judge Smith 'a non consistent liberal'(1988: 69-71). Smith is not blind to the possibility that an army can become a threat to civil liberty, but thinks this will not be the case as long as the army is placed under the civil command of the sovereign. In many cases, the army may act as a protector of freedom because it also turns down small internal strife. Another advantage of standing armies is, paradoxically, the expenses involved. Only the most prosperous nations can afford the best defence and since these are also the most civilised nations, civilisation in general will be spread through them winning wars (WN: 689-708). Militias are purely defensive forces, and are home bound, so as Neimanis (1980: 29) expresses it: 'in Kiplingesque words, the white men's burden cannot be carried by militia'. Hence, while not completely rejecting them, Smith differed in this respect from his friends, with whom he regularly met in a society called The Poker Club, among them Hume and Ferguson, who were actively campaigning for a Scottish militia (Winch, 1996: 117-119). Hence, Smith's attack came at a bad moment for his opponents. A parliamentary bill to raise one was discussed (and defeated) in parliament around the publication of the Wealth of Nations (Sher, 1989: 246-247).

Commerce and war are related in Smith's view. As indicated earlier, Smith regularly refers to the bellicose side-effects of international trade relations. The flip side of free trade is that it enables countries to carry on foreign wars and to keep fleets and armies in distant places (WN: 440445). Insufficient defence is a danger to the stability of the state, which in its turn will inevitably lead to a loss in national wealth. This is another rea- 
son for Smith to argue that 'defence is more important than opulence', as one of his most famous expressions has it. He does not defend the position that economic interdependence promotes a harmony of interests between societies (Margerum Harlen, 1999: 735-736). Only the combined efforts of diplomats and the military can ensure prosperity through trade. Admittedly, Smith (like Hume) also points at some peace enhancing traits of commerce, for example the different individual virtues that are directly related to the act of trade. Yet he does not foresee, nor predict, a development towards peace from commerce and trade alone. Peace in the commercial age still depends on measures of 'high politics', like building strong nations and wise statesmanship, supported by a martial spirit of the people and, if needed, the use of force (Manzer, 1996). War is not one of his foreign policy goals, yet its occurrence is inevitable, in the commercial age as much as in earlier times.

\section{Free trade}

The best known part of Smith's ideas on international relations is his defence of free trade, which widens markets, stimulates economic growth (Bloomfield, 1975: 456) and creates wealth for all individuals involved. In contrast, mercantilism is the political economy expression of special interest, most notably those of merchants and manufacturers who have a natural desire for monopoly and the shifting of their risks, while continuously attempting to make people believe that this is in the general interest (Fleming, 1976: 164-165). Smith strongly rejects this type of economics and differs from the mercantilists in two other ways. He considers the state as a society of all wage-earners, instead of just the property holding, cultural elites. He also rejects the idea that able statesmen are able to plan the economic affairs of the nation. Mercantilism focuses on the transfer of wealth, while Smith concentrates on the production of wealth (Sowell, 1978: 152-154).

Smith notes with disapproval that the leaders of nations have somehow been taught that their interest lies in beggaring their neighbours, in the false belief that trade is a zero sum game. Countries look jealously at the increase in wealth of other nations, and consider the gains of others as 
their own loss. Smith holds that commerce, among individuals as well as nations, 'ought naturally to be' a bond of union and friendship, although he readily admits that trade cannot overcome the nature of human affairs, which manifests itself in the violence and injustice of the rulers of mankind. The most foolish ambitions of kings and princes cannot match the immense losses resulting from the jealousy of merchants and manufacturers. Trade has become the eternal source for discord and animosity, but the mischief of the tradesmen towards their fellow citizens can and should be prevented. In every country it is always in the interest of the majority of people to have access to free commerce and trade (WN: 493).

Free trade should be extended to most commodities. Governmental efforts to control the import and export of money and precious metals are fruitless, as are concerns over the balance of trade (WN: 434). No nation can be ruined by a negative balance of trade (LJA: 392). 'What is prudence in the conduct of every private family, can scarce be folly in that of a great kingdom'. If a foreign country can supply cheaper or better goods than the domestic industry, a nation should employ its industry in an area where it has an advantage (WN: 457-459). Smith, like Hume, thinks that policies to preserve the balance of payments are misguided. There is no reason why that balance cannot look after itself (Cairncross, 1976: 118). In fact, almost all regulations that distort trade are founded on absurd notions. When conducted without force or constraint, trade is always advantageous to both parties, in terms of increased annual revenues, even though the wealth may not always be equally distributed within a state (WN: $488-$ 489). Therefore, Smith supports free trade with the Irish (C: 240-244) and thinks that if the American colonies would treat all nations alike in matters of duties, that would set a shining example to the world (C:271).

Smith is no absolute free trader, as for example Rothbard notes with strong disapproval (2006b: 433-474). There are a few cases for restricting trade by putting burdens on foreign industry to the advantage of domestic industry. First is the concern for industry involved in national defence. In relation to 'high politics' trade restrictions are justified, even though they breed monopoly and other disadvantages: 'defence is of more importance than opulence' (WN: 463-465), and the wealth of a foreign nation can be dangerous, as it enables it to keep fleets, armies and the opportunity to develop superior weaponry (WN: 494-496). Second is to equalise the 
terms of trade between domestic and foreign competitors, especially when there are differences in the way the produce is taxed (WN: 465). Third, a difficult situation arises when a trade war breaks out and there is demand for retaliation. Fourth, shortly after trade is interrupted for example by war, the domestic industry may need time to recover its competitiveness, as it also needs to absorb the returning soldiers and sailors (WN: 467-470). For special interests are always grounds to somehow limit free trade beyond these exceptions, Smith notes with some disgust. Hence his conclusion: 'to expect, indeed, that the freedom of trade should ever be entirely restored in Great Britain, is as absurd as to expect that an Oceana or Utopia should ever be established in it'(WN: 471). Hence, the national defence aspect is an important reason for Smith to restrict trade.

\section{Empire and American Independence}

Adam Smith is generally hostile towards imperialism, colonialism and slavery. This applies to the future of the American colonies and to the less developed parts of the world. He strongly opposes the related oppression and (economic) exploitation. Colonialism is unjust and harmful to both colonisers and colonised, because it goes against his ideas on natural liberty and justice (Billet, 1978: 103-107). Pitts makes clear that in contrast to many liberal successors who defended empire, like Mill and Tocqueville, Smith was broad-minded in his analysis of unfamiliar societies and not prejudiced against other people. The most important difference with these later liberals 'who turned to empire', is that he did not think Western society was superior or that Europeans had a historical role to further advance or educate other nations. Instead, these other societies were in one of the three earlier stages of development (hunters, shepherds, agriculture respectively) and in principal would also be able to advance to higher stages, with commercial society as the ultimate reachable goal (Pitts, 2005: 25-58). The American Indians are an example he often referred to (Blaney and Inayatullah, 2006). Besides Britain, only Holland seems to have come anywhere near to the commercial stage of society. In Smith's view, the more illiberal, authoritarian and oppressive the political system of a country, like France, Spain and 
Portugal, the more removed it is from the most advanced stage of development (Coats, 1975: 232).

Smith writes that the establishment of colonies is neither needed or expected to raise utility (WN: 558). The most important lesson to be learned from the American experience is about the role of freedom. It is not the wisdom and policy of European governments that peopled and cultivated America, as they only left disorder and did many injustices to the settlers. Europe only deserves credit for the education and the great views of the founding settlers (WN: 589-590). The main reason for the colonies to prosper is exactly the inability of their 'mother countries' to strictly govern them. The colonies grow rich due to the abundance of good and cheap land, combined with all kinds of freedoms; the opening of a new and inexhaustible market to all commodities; new divisions of labour; higher productivity; and new sets of exchanges, improvements in arts and sciences and (WN: 448-449, 567, 570, 572). Europe 'considered as one great country' gains from the colonisation of America through the introduction of unknown products and commodities, increased governmental revenues and the empowerment of the military might of the (British) empire (WN: 591-609). Smith thinks the discovery of the East Indies is of even greater importance to foreign commerce, even though European governments make the mistake of setting up exclusive trading companies, like the Dutch East India Company. This means the fruits of real free trade are not harvested (WN: 448-449).

European imperial policies have a lot of direct and opportunity costs. The lack of free trade with the British subjects (Rae, 1895: 384) in the American colonies is detrimental to the general welfare of Britain. It is also one of the worst violations of the sacred rights of mankind (WN: 581-82). For Smith, there is a direct relation between the political problems of the colonies and fiscal considerations (Stevens, 1975: 208). Trade related advantages are shared with other nations, while the inconveniences of keeping colonies, for example their defence, are the sole burden of the coloniser, (WN: 628). The English colonies can afford low taxes because they do not contribute to the defence of England, even though the British defend them (WN: 573). For Smith, this is another reason to argue that the British should let the colonies govern themselves (Pitts, 2005: 52-58). 
In a paper dated 1778 (discovered in 1929), Smith provides more detailed thoughts on the American question. He initially distinguishes four possible solutions. First, the complete submission of America, with all colonies contributing towards the expenses of the Empire. Second, complete freedom for America, without any bonds with Britain. Third, the (near) restoration of the old system, for example with Crown appointed Governors, but without contributions from the colonies for defence. Fourth, a part of America will be submitted to the British, while the rest becomes independent. Smith thinks the first three options are very unlikely, for various reasons which we need not elaborate upon here. The fourth option is the most probable, but also the most unhappy outcome to Great Britain. Instead, he favours a federal union with parts of America with common representation and a constitution. Canada should be returned to France and the Floridas to Spain. This incurs less expense, while real advantages of parting as friends loom large, such as the formation of natural alliances in international political affairs. However the other European nations would consider this outcome shameful to Great Britain, it is too painful for national pride and, more importantly, always against the private (financial) interests of the rulers. Therefore Smith does not expect this to happen (C: 380-385; WN: 616-618), it would require more statesmanship than is available on either side of the Atlantic (Fagerstrom, 1954: 258). Full separation is a more likely outcome (Skinner, 1979: 184) and it seems inevitable blood shall be shed, even though it will be impossible for Britain to lay down its rules by military action (WN: 623-625).

Although Smith refers to himself in this context as 'a solitary philosopher' without support, he was not alone in his plea for a constitutional union. Franklin, Lord Kames and Governor Pownall suggested such schemes before him. Although they were without success in the American case, it is argued that the model of constitutional union was implemented in the case of the parliamentary union with Ireland of 1800 under the leadership of Pitt the Younger, who was strongly influenced by Smith (Stevens, 1987). 


\section{IR and Adam Smith}

Compared to Hume, Smith is less often mentioned in IR-texts and in the few cases he appears is often misinterpreted (Kauppi and Viotti, 1992: 204). There are hardly any articles on his international relations as a whole, nor is he mentioned in many general overview articles on the liberal tradition in IR. M.J. Smith (1992) even succeeds in writing a chapter on the liberal tradition in IR without considering Smith's (or Hume's) ideas at all. Instead, he focuses on Kant and nineteenth century thinkers like Bentham, Cobden, Bright and both the Mills. Burchill (2005) follows this one-sided example in a popular text book, and refers to Smith in only a few minor cases related to economics. This is actually common practice. If Smith's name is mentioned by IR scholars, it is almost exclusively in relation to trade and economics. His ideas on imperialism are mentioned in a few minor cases, and in many other instances his name is just dropped without much further consideration of his ideas (see for example Northedge and Grieve, 1971: 49, 244; Waltz, 1954: 86, 89, 94, 195; Jackson, 2005: 133; Holbraad, 2003: 40, 187; Baldwin, 1993: 21-22; Richardson, 2001: 32, 35, 42, 124; Keohane, 1989: 19, 51, 52, 211; Wight, 2005: 75; Walker, 1993: 94; Brown, 2002: 52; Brown, 2001: 153; Wight, 1991: 114, 263; Smith, 1992: 204). The point is not that these references are erroneous, but that they are incomplete and fail to appreciate Smith's international relations in full. Sometimes this incomplete picture does lead to mistakes. Many modern commentators, most influentially Doyle (1997: 231-241), but for example also Howard (2004: 25), Oneal and Russett (1997) and Panke and Rissen (2007: 97) are obviously wrong when presenting Smith as an early proponent of the thesis that economic interdependence leads to peace, an issue that shall be further elaborated upon in chapter seven.

However, there are a few writers who analyse Smith's ideas on international politics in more depth. Polanyi gives a critical, but generally fair representation of Smith's work, although his focus is still mainly economic. He points at Smith's distrust of the ruling elites, calls him 'the initiator of anti-imperialism' and gives him credit for anticipating the American Revolution (Polanyi, 1957: 212, 137-140). Carr erroneously regards him as the founder of the laissez-faire harmony of interest doctrine in international relations. He argues that Smith's followers, among whom Carr counts J.S. 
Mill, T.H Green, Bastiat and Bagehot, stretched this notion to the realm of nations, instead of limiting themselves to individuals. Carr shows his Marxist credentials in his criticism of Smith's free trade principles, on the grounds that free trade was never accepted outside Britain and his assertion that 'biologically and economically, the doctrine of the harmony of interests was tenable only if you left out of account the interest of the weak who must be driven to the wall, or called in the next world to redress the balance of the present' (Carr, 1995: 42-49). For the present purposes it is most interesting to note that Carr presents Smith as the quintessential arch-Utopian in international relations. Hammarlund in a way supports this view by solely referring to Smith as a major influence on Richard Cobden (2005: 3, 13, 33, 87), a writer who fits Carr's description far better as shall be discussed in the next chapter. Brown, Nardin and Rengger point out that Smith was 'always conscious of the need to moderate the cosmopolitan policy implications of the laws of political economy by giving due weight to the requirements to preserve national power' (Brown et al., 2002: 521). Hence, they rightly note that Smith was not a cosmopolitan and that he cared about the state, but obviously miss the point that for Smith there is no necessary link between 'the laws of political economy' and 'cosmopolitan policy implications'.

The most extensive analysis of Smith's views of international relations is provided by Andrew Walter (1996). He forcefully argues against aforementioned IR theorists like Carr, Wight, Waltz, Gilpin and Howard, who all consider Smith a revolutionist, a cosmopolitan, or even one of the founders of liberal internationalism (a theory which will be further discussed in chapter seven). Walter is right to note that this rests more on 'a tendency to read back nineteenth century ideas into Smith, than a close analysis of Smith's own works, his purposes and his intellectual milieu'. Walter also underlines that Smith saw perpetual sources of conflict at the international level which leaders of states need to take into account. Since there is no Smithian belief in a natural order of harmony at the international level, he concludes that Smith has a fundamentally realist view of international relations, which is ultimately founded on his view of human nature (Walter, 1996: 142-143, 149, 156).

It is clear Smith is more a realist than a Kantian. Walter seems to overlook the Grotian option, despite the fact that he notices that Smith 
offers a bridge between realist and liberal analyses of the relationship between power and wealth in international relations (1996: 144, 159). He tends to overemphasise the 'combatant' parts, while understating the importance of the Grotian tradition of international society for Smith's ideas on world politics. Smith and Hobbes differ in many respects, especially when it comes to the role of the state in the life of the individual. To ensure welfare and security, Hobbes argues in favour of an absolute sovereign (Spengler, 1978: 40-50), while Smith calls for the loyalty of the people to the sovereign, but at the same time emphasises the need for a large degree of freedom and for limits to the state. Despite similarities in their views on human nature, the appreciation of the role of the state in international affairs and the balance power, Smith is no Hobbesian in his domestic politics (Long, 2006: 306), nor in his international politics. He put far more emphasis on the value of international society, the need for just war, the idea behind the laws of nations and generally the negative sides of warfare and glorification of the state. Therefore, Smith cannot be regarded a realist, nor was he a forerunner of nineteenth century liberal nationalism and imperialism. Fleischacker (2004: 250-257) is partly right to decouple Smith from nationalism, but wrong when presenting his ideas as 'pacific cosmopolitan', the same term Doyle uses.

In the nineteenth century some scholars emphasised that Smith cannot be seen as an 'apostle for perpetual peace' (Oncken, 1877: 140-146). In his political philosophy, Smith rejects Utopianism, for both moral and epistemological reasons. He considers Utopian theories speculative constructions of philosophers, which fail to take into account individual behaviour in concrete situations. This type of thinking is far too rationalistic for his taste. He thinks external defence is the first and most important task of the state (Haakonssen, 1981: 91-95), which shows his non-Utopian expectations about the international environment. His view on human nature is not so positive as to enable a belief in Utopia, he rejects revolutions, does not think international conflict can be abolished, nor does he anywhere support schemes for the creation of a supranational state. Even the promotion of free trade, while an absolute necessity for many reasons, is not expected to substantially change international affairs. War and the balance of power remain too important in Smith's views on international relations to consider him a Kantian (also see Margerum Harlen, 1999). 
There are several reasons to regard Smith as a Grotian instead. While he does not elaborate on it, Knutsen $(1997: 149,225)$ is one of the few IR theorists who establishes a relation between Smith and the natural law tradition, even though, as noted above, a number of Smith-scholars, like Teichgraeber (1986) wrote about that relation. More generally, the influence of Grotius and Pufendorf on Scottish legal thinking has been significant. Especially in the first half of the eighteenth century, many Scottish students [but not Hume or Smith, EvdH] went to Leiden and Utrecht to attend private classes on these natural law scholars (Cairns, 2003: 227). It is known that Smith studied Grotius' and Pufendorf's work throughout his life (Ross, 1995: 72, 120; Irwin, 1996: 69; Rashid, 1994). Of these two, the influence of Grotius appears most profound (Lieberman, 2006: 218219), he also owned several of the Dutchmen's works in his private library, often in more editions, like The Rights of War and Peace. He explicitly refers to Grotius in the Theory of Moral Sentiments and the Lectures on Jurisprudence, despite the contemporary custom to work without exact references (Mizuta, 2000: xvii, 108-110, 207).

In Smith's view human nature makes it impossible to get rid of conflict. He values the institutions of the international society of states for the provision of order, in particular diplomacy, international law, (just) war and the balance of power. Without order, free trade cannot have its positive effects on increasing the material and immaterial welfare of all people. Imperialism and colonialism are also of negative influence in this respect. Like Vattel (Jeffery, 2006: 71) Smith regards international society as founded on the mutual recognition of the sovereignty and legal equality of states. In his politics he was very moderate, promoting tranquillity and civilised order (Long, 2006: 315), so both perpetual war as revolutionary overhauls of the international world were unattractive alternatives for him. Hence, the evidence to consider Smith a Grotian is stronger than any of the other possibilities within the English School. Like Hume, within the Grotian tradition he must be seen as pluralist, considering his views on war and human nature.

To reiterate some of the main findings in the present and the preceding chapter, there are no serious signs of a revolutionary or Kantian persuasion in the views on international relations of two of the greatest eighteenth century classical liberals, Hume and Smith. Clearly, they were 
not visionaries for a 'society of peace and freedom' as Ebeling (2003b: 174) erroneously asserts. It would be easier to classify both writers as realists, but closer scrutiny revealed that is does their ideas more justice to regard them as pluralist Grotians. Their views on the nation, balance of power, war, free trade and imperialism clearly differs from the most common perspectives on liberalism in IR. The analysis of the ideas on international relations of Mises and Hayek will show if they also think along these lines. 


\section{5 \\ Ludwig von Mises, Capitalism and Peace}

Like Hume and Smith, Ludwig Heinrich Edler von Mises (1881-1973) is mainly known for certain parts of his work. However, of the four classical liberal thinkers studied in this thesis, Mises has written the most on international relations. Two of his books, Nation, State and Economy (1919) and Omnipotent Government (1944) are exclusively devoted to international topics, while he also discussed international issues in many other pieces. This is not surprising, since his life was deeply marked by the two world wars. Born in Lemberg, in the eastern part of the Austrian Empire, he served as an officer in the Austrian Army in the First World War. In 1934 he escaped from Nazism, first to Geneva and from there in 1940 to America. He became a United States citizen and lived in New York City until his death (for more on Mises' life see Hülsmann, 2007; Ritter von KuehneltLeddihn, 1999; Ebeling, 2003a: 61-100; Butler, 1988; Rothbard, 1988; Von Mises, 1984b; Von Mises, 1978b; Kirzner, 2001).

In interwar Austria, Mises was one of the most influential and most famous economists, not least through his position at the Vienna Chamber of Commerce. Besides his full-time duties at the Chamber he published numerous books, articles and newspaper co-editorials. He was the leading thinker of the third generation of the Austrian School of Economics, taking over from his mentor Eugen Von Böhm-Bawerk, who worked in the tradition established by Carl Menger. Mises is most famous for his writings on the epistemology of economic theory, the theory of the business cycle, subjectivist economics, the theory of money, and especially for his fatal blow to socialist economics (Von Mises, 1990a). Early in the 1920s he showed that socialism cannot work because it lacks a price system, mak- 
ing it impossible to make economic calculations. Therefore any socialist planning system fails, as there is no ground for determining the value of commodities or services (Boettke, 1994; Kirzner, 1992).

Besides being a productive author, Mises was an influential teacher. He never held a full professorship, but acted as an unsalaried Privatdozent to the faculty of law at the University of Vienna, where he taught weekly seminars between 1913 and 1938. Additionally, Mises organised his now famous Privatseminar for students with a doctorate, held every fortnight at his office in the Chamber of Commerce, from 1920 to 1934 . Around twenty five selected students and guests gathered to discuss economics, social philosophy, sociology, logic and the epistemology of human action (Von Mises, 1978b: 93-100). He became the driving force behind the intellectual development of the important fourth generation Austrians, consisting of academics such as Hayek, Machlup, Haberler and Morgenstern. After the Second World War he lectured at New York University Business School and again succeeded in attracting and guiding an increasingly important following, among them Israel Kirzner, Murray Rothbard, Hans Sennholz and Bettina Bien Graeves (Delgaudio, 1987). Many of his students recall being struck by his gentleness and humour in personal contact, in part because he had a reputation, which was 'fully justified' according to his widow, for being uncompromising in academic and public debate (The Mont Pelerin Society, 1974; Andrews, 1981: 10-13, 19-27).

In this chapter Mises' economics will hardly be touched upon, since that topic has been analysed at length by numerous other authors (for example Rothbard, 1980a; Kirzner, 1982; Steele, 1992: 95-122; Moss, 1976). Here, the central focus is on his international political thought, a largely overlooked area. This neglect is partly due to his own friends and followers. For example it is telling that out of the sixty six contributions in a two volume Festschrift offered to Mises on his ninetieth birthday (Harper, 1971), not one seriously analyses his ideas on international relations. Despite its many references to international politics, the same holds for a book commemorating his magnum opus Human Action (Ebeling, 2000a), while his views on international relations are briefly and incompletely touched upon in one contribution (out of twenty) in a 1956 collection of essays to honour Mises (Sennholz, 1994). His biographer, Jörg Guido Hülsmann (2007), in his massive and rich text, does not give a full analysis either, 
although his book provides sufficient insight into many elements of Mises' international relations.

\section{Mises as a classical liberal}

It might appear strange to analyse the classical liberal credentials of a thinker who continuously stresses his adherence to this tradition. Yet, Mises commenced writing about one hundred and fifty years after Smith's death, so it is important to see if his classical liberalism still resembles that of his Scottish Enlightenment predecessors.

Mises consistently positions himself in the same tradition as Hume and Smith, although he also mentions Ricardo, Bentham and the Manchester School as his liberal sources. For example, he states that British political economy is most brilliantly expounded by Hume and Smith and perfected by Ricardo. It is 'the most exquisite outcome of the philosophy of the Enlightenment' (Von Mises, 1984a: 20; Von Mises, 2003: 3-4). Smith's books are the 'consummation, summarisation and perfection' of the work of previous scholars, laying the keystone, of 'a marvellous system of ideas' called capitalism (Greaves, 1990: 115-117, EF). He particularly values Smith for his rejection of increasing the money supply (Von Mises, 1981b: 464) and warmly recommends Hume and Smith to anyone who wants to become acquainted with the 'liberal mind' (Von Mises, 1996d: 194, L). Hume and Smith are also praised as the greatest intellectual founders of sociology (Von Mises, 2002a: 183), or the science of human action, which Mises later renames 'praxeology'. Perhaps characteristically, his adherence is not unconditional. Mises warns that a study of Smith is not enough to get an understanding of the richness of classical liberalism, since it has developed further since the times of the Scots (Von Mises, 1996b: 34). Nevertheless, following the definition in the first chapter, here is a clear example of an intellectual tradition, with the later author (Mises) fully acknowledging the influence of his intellectual predecessors (Hume and Smith) and stating his wish to further develop his ideas along their line of thought.

Like Hume and Smith, Mises starts his economic and political analysis with the individual. Following Menger and Von Böhm-Bawerk he under- 
lines that only individuals act, not groups nor collectives (Gordon, 1996: 25). His view on human nature is realistic. Man starts life as a very weak suckling who needs the protection of his parents, who in turn need the protection of society (Von Mises, 2000a: 19). Born as asocial and antisocial beings, only through their upbringing and contacts with other people do humans start to co-operate and behave socially (Von Mises, 1985: 251, OG). Man is liable to error; in fact 'if to err were the characteristic feature of mental disability, then everybody should be called mentally disabled' (Von Mises, 1996c: 186, HA). However, Mises thinks that man is able to use reason to act in his rightly understood interests (L: 5, HA: 73, 177). So, while human reason is fallible and people often make mistakes in selecting and applying means to reach their ends, reason does enable people to control their urges and emotions. Like Hume, Mises holds that in certain cases the emotions can be too strong to oppose. However, he asserts that this still remains a choice; it is not beyond human control: 'man is not a puppet of his appetites' (HA: 16-20). Mises refers to Hume as a rationalist philosopher, but adds approvingly that Hume was certainly not guilty of exaggerating the power of man to attain truth (HA: 73). Rationalism is more important to Mises than to Hume and Smith. In his foreword to the 1981 edition of Socialism, Hayek exaggerates by noting that Mises was under the spell of 'extreme rationalism', which Hayek thought was due to historical context, from which Mises retreated later in life (in Von Mises, 1981a: xxiii-xxiv, S). The apparent dichotomy is not so strong as it seems. Mises clearly rejects to the overrating of the possibilities of human reason (HA: 72).

Mises did not fall into the constructivist trap (Cubeddu, 1993: 201206), nor did he embrace logical positivism (Gordon, 1996: 31-38); scientism, the work of Comte, and positivist metaphysical thought are 'illusory' and cannot have a place in his theory of human action (Von Mises, 2005: 160-166, HA: 30-31). Mises (HA: 32-36) argues that knowledge is a priori, while the Scots were firm empiricists. This lead some scholars to claim that he was 'a neo-Kantian' (Leeson and Boettke, 2006), but Kantian epistemology did not have a noticeable impact on his thought (Hülsmann, 2007: 42). While of course of interest, this issue will not be elaborated upon here. The possible answers do not influence his qualification as a 
'classical liberal', nor his views on international relations in more than a remote way.

Mises believes social contract theories cannot explain the origin of the state and the laws because they lack historical proof (S: 32-33). Theological and metaphysical doctrines that prescribe individuals to follow the command of a God or nature are also rejected (Von Mises, 1996b: 74). He regards natural law and natural rights almost solely in terms of theology and thinks natural rights are illusory, as it is not possible to limit or define them sufficiently (Hülsmann, 2007: 410). His laws of nature are related to the physical and biological limits that are set upon humans (Greaves, 1990: 96). However, his rejection of all kinds of natural law is puzzling, if not clearly inconsistent. First of all, Mises believes in inalienable individual rights to life and property. While these need a philosophical grounding, he fails to provide one, which is rather inconsistent for a writer who attaches so much importance to theory. Mises only points to the formal utilitarianism of human action, but the fact that an individual acts in a certain way, using his reason to weigh up and choose from alternatives, does not provide a sufficient framework for judging inter human relations. As Rockwell and Tucker notice, Mises appears to use natural law type constructs in spite of his explicit rejection of natural law (Tucker and Rockwell, 1993: 318). Gonce (1973) even goes so far as to claim that Mises' system is based on individualistic secular natural law philosophy, influenced by Grotius and Pufendorf among others, although this is strongly rejected by Rothbard (1980b). Mises seems strangely unaware of a secular natural law tradition, but his reasoning is much closer to Hume and Smith than often assumed. According to Yeager (2000: 235-249), Mises did not reject natural law and human rights as ethical precepts, but only the 'exaggerated, foundationalist, almost mythical status, that some writers give to these notions'.

Mises follows some of Bentham's utilitarianism and embraces the Ricardian notion of 'social utility', which is the idea that social cooperation is beneficial to all groups and individuals, as are the institutions that develop to enable human interaction, like democratic government, private property, freedom and equality under the law (HA: 175). Later in his career he makes it clear that he rejects Bentham's application of utilitarianism in politics, especially the 'greatest happiness-principle', which in his view confuses 'liberty and despotism' (Hülsmann, 2007: 307, 410-413, 523-537; 
Von Mises, 2005: 44-45). In the twentieth century democratic context it also gives unlimited power to the will of the collectivist majority, which for Mises also makes a significant difference with the nineteenth century. It is therefore strange that his utilitarianism is harshly criticised by writers in the libertarian tradition, most notably Rothbard, who points out that Mises uncharacteristically disregards the differences in value preferences among people. Because the majority of people hold a certain position it does not make it a right position. 'To make the full case for liberty, one cannot be a methodological slave to every goal that the majority of the public happen to cherish' (Rothbard, 2002: 206-214). This obviously misses the point and it is safe to claim that Mises is much closer to the utilitarianism of Hume and Smith than is commonly understood.

While never enthusiastically embracing the idea of 'spontaneous order', it is logical that the outcome of his ideas about the division of labour and the absence of planning indeed lead to spontaneous order in society (Steele, 1992: 229-237). 'Liberal social theory does not explain formation and progress of social ties and institutions as consciously aimed human efforts toward the formation of societies [..] It views societal organisations as "the unconsidered result of specific individual efforts of members of society"'(Von Mises, 1996b: 76).

Rousseau and the Romantic philosophers are wrong in suggesting that that the individual was free in the early ages of history and later became enslaved by society. 'There is in nature nothing to which the name of liberty could be given'. Society is needed to secure individual freedom; it is a mutual exchange of services. In it, absolute individual independence is illusory because the individual always needs to contribute to the well-being of other people, while in turn depending on them (Von Mises, 1991: 32). Mises asserts without the state society is not possible, in contrast to some of his modern (anarcho-capitalist) followers. The state is a good institution that has a limited number of tasks (Hülsmann, 2007: 742-745). In Mises view, 'classical liberals are not so foolish as to aim at its abolition' (OG: 50). Government is essentially the negation of freedom, it uses its power to make people obey, whether they like it or not. 'Government is not [....] a necessary evil, it is not an evil, but a means, the only means available to make peaceful human coexistence possible. But it is the opposite of liberty. Government is the most beneficial human institution, because human na- 
ture forbids humans to establish a civilisation or peace without the government apparatus of violent action. Freedom can only be found in the sphere in which government does not interfere' (Von Mises, 1991: 33). Perfect government is the foolish and erroneous idea of the social engineer, who overlooks the fact that government and state cannot be perfect as they owe their existence to the imperfection of man (Von Mises, 2002b: 96-99). The state's tasks should be strictly limited to the protection and preservation of life, liberty and property, with a key role for the rule of law, he contends in a full blown natural law fashion. He even adds securing the health of the individual as a state task (L: 111-118).

The economic foundation of classical liberalism is essential for Mises. $\mathrm{He}$ is 'one of the most passionate, consistent and intransigent defenders of capitalism' (Younkins, 2005: 49). He does not hesitate to refer to it as the system of laissez-faire (Von Mises, 1980: 34-47). Capitalism is the system of social cooperation and division of labour, based on private ownership of the means of production. The producers are instrumental but not supreme, they do not determine what is produced (Von Mises, 1996a: 23; Von Mises, 1994). 'Laissez-faire does not mean: let soulless mechanical forces operate. It means let each individual choose how he wants to cooperate in the social division of labour, let consumers determine what the entrepreneurs should produce. Planning means: let the government alone choose and enforce its rulings by the apparatus of coercion and compulsion' (HA: 731). The division of labour is a key concept, social development only occurs when increasing numbers of people are included (S: 271-273). For some, Mises transfers the Ricardian law of co-operative advantage into a law of human association. Social cooperation under the division of labour is the sole route to human survival and the creation of its spiritual and material well-being (Younkins, 2005: 67-72).

Despite some inevitable differences with his Scottish predecessors, Mises stands in the same classical liberal tradition. To his regret, the world never lived in a liberal era, because classical liberalism was never fully introduced (L: 1,3). In his view this is partly due to the nineteenth century, when 'new liberals' captured the popular mind, yet they were in fact 'antiliberals in disguise' (OG: 4). One of the major aims of his work is to reverse this negative development. 


\section{Nation and Nationalism}

Mises acknowledges the importance of nations for individuals. A nation is a social collective, which comes into being through the actions of its members (HA: 43), and is different to a state, 'the nation as an organic entity can be neither increased nor decreased by changes in states, the world as a whole can neither win nor lose from them' (Von Mises, 1983: 39-40, NSE). Most of his ideas about the nation are based on his experiences in Eastern Europe, the region where he was born and raised. With the scattered German nation and the fragmented population of the Austro-Hungarian Empire in mind, he argues that the idea of a nation cannot relate to a geographically bound location, because people move and borders are dynamic. Ancestry does not play a role either, as 'there is no nation of pure blood'; hence nation and race do not coincide. Instead, for Mises, nations are primarily speech communities; the essence of nationality lies in language (Butler, 1988: 17), although he also acknowledges the importance of other characteristics such as race (Hülsmann, 2007: 317). On this point he deviates from the more generally accepted modern definition of the nation, provided in the introduction.

Language itself originates in a social or ethnic community. A common language binds; differences in language separate. Language determines the way individuals think and express themselves. Consequently, people who do not (properly) master a language cannot be counted full members of the nation (NSE: 9-14), as it happens a view also held by Fichte (Kedourie, 1993: 117) not normally a friend of Mises (HA: 721). Members of nations cannot speak more than one language, which leads Mises, with foresight, to predict the division of both Czechoslovakia and Yugoslavia. Britain and America appear at first sight two nations using the same language, but Mises holds that they are actually one nation, even though they are not unified in one state. The same is true for Norway and Denmark (NSE: 16-21). Later, he defers from this idiosyncratic position, by acknowledging that the US and UK are separate nations, and that the French do not regard the French-speaking parts of Belgium, Canada or Switzerland as part of their nation, but as French speaking foreigners. He also acknowledges that for the individual human language is not necessarily a stable factor in life, 
because people can move and change language (OG: 82-85). That nations are important to individuals cannot be doubted.

Contrary to Hume and Smith, Mises does not believe in the idea of national character as a predictor of individual action. It presupposes too much stability in its constituent characteristics and in its influence on the individual. Mises has such a strong opinion on national character, because he rejects the popular idea among his contemporaries that Nazism is the outcome of 'the German character'. He feels this is bad science and unwarranted generalisation. Nevertheless, it is possible to speak of a nation's mentality at a certain point in time, but only if the definition of national character is reduced to 'the will of the majority' which is subject to change. Otherwise, the idea of national character is mainly the result of 'precipitate and ill-considered induction from an insufficient number of ill-sorted examples'. (OG: 241-243).

Given the historical context of his writings, it is no surprise that Mises puts emphasis on the role of nationalism, or 'the principle of nationality', in international relations. He agrees with many commentators that nationalism is related to modern politics. However, this in itself is questionable, since, as shown in the two preceding chapters, the idea of nations and nationality had a powerful presence in the eighteenth century as well. There were nations before nationalism (Smith, 1999: 97-123). For Mises there are two possible political outcomes of the development of nationalism, a liberal, or pacifistic variant and a militant, or imperialistic one. In the first, the boundaries of state and nation coincide, as in his view is the case in France or England. This nationalism is not directed against other nations. The nation concerned wants peace and friendship with its neighbours, so the idea of freedom reigns.

Militant nationalism develops in areas of mixed populations. It is the dangerous type, 'the policy of cool-minded Machiavellian politicians', and even stands in opposition to chauvinism, which is just 'an overestimation of one's own nation's qualities and achievements and a prejudicial disparagement of all other peoples' (Von Mises, 1990c: 156-157, MMM). Obviously, the principle of linguistic nationality cannot work in multi language territories (OG: 85), where genuinely opposed interests exist between minorities and majorities. Introducing democratic majority rule in such polyglot territories creates situations where the rights of minorities are not 
respected, which leads to struggles between nationalities (NSE: 31-56). This fighting aims at control of the state, which can only be limited in importance if the state does not have much power, or hardly any means at its disposal (Gordon, 1993: 133; Hülsmann, 2007: 316-324). While Mises' idea of pacifist nationalism in Western Europe does not really stand up to historical scrutiny, he is right about the different situation in Eastern Europe. There, due to the fragmentation, the creation of culturally homogenous states can only be accomplished by ethnic cleansing (Gellner, 1997: 50-58).

For Mises the liberal solution to problems of nationalism is individual self-determination (OG: 93-94). Each individual should be free to change nationality or to emigrate, while colonies should become independent if they wish (NSE: 39). In practice, this means that groups of people can decide, by plebiscite, about their national future (Ebeling, 2000b: xxxv). Mises thinks that the size of the state's territory and the number of inhabitants does not matter much, although not every individual, or small group, can start their own state. At a minimum, there should be 'several hundred thousand speakers', which in his view is the number required to keep an independent standard language alive and in most cases it is also the number needed to finance the state tasks. Smaller nations do not and cannot exist (NSE: 82). Baumgarth notices that, contrary to Mises intentions, this stretching of the right to self determination may easily lead to anarchy (1976: 93), while the libertarian secessionists criticize him for being to strict a defender of states (Hülsmann, 2007: 1026-1029). Raico (1996: 24-25) adds that Mises overlooks the fact that free immigration is in a different category of policy decisions, because the influx of immigrants may actually be a threat to an existing liberal social order. The newcomers may radically alter the democratic political body, owing to their different histories and cultural backgrounds. Mises' focus is more on the people who want to leave a certain state.

In his personal life Mises was often confronted with the worst outcomes of militant nationalism. It is therefore more remarkable that he never proposes to get rid of states all together, in contrast to many other liberal thinkers. A one-state world is only acceptable if it is the outcome of a natural and free process, but Mises thinks this is a very remote theoretical option. As shall become clearer below, Mises argues that the principle of 
national sovereignty is fully compatible with the international division of labour and peaceful international collaboration. His only condition is that all countries cling to democracy and capitalism (MMM: 151-152). If states have a limited number of tasks, their importance diminishes accordingly. Liberalism does not aim to abolish the sovereignty of states, not least because it would also lead to endless war (HA: 686). People are free to decide to what extent they want to harmonise their laws with those of other states (NSE: 38), they may even leave states in groups, if that is what they prefer. In most cases this would lead to more states, not to a decreased total number of states. For Mises, like Hume and Smith, states will remain in the foreseeable future the leading actors in international relations, grounded as they are in the individual feelings for the nation.

\section{Mises and International Relations}

The international relations of Mises cover at least as many fields as those of his eighteenth century classical liberal predecessors. Two things stand out: his emphasis on the issue of war and his economical viewpoints. As in his other writings, his overriding concern is with enlarging individual freedom, which generally implies minimising the role of the state and maximising economic liberty.

\section{War and peace}

Superficial reading of Mises can easily lead to the conclusion that he must have been one of the greatest pacifist thinkers of the twentieth century. $\mathrm{He}$ never tires of warning against the devastating effect of warfare and actually hardly ever stops talking about the war. According to his former student Engel-Janosi (Bien Greaves, 1958a), he took his own army experience very seriously (see Hülsmann, 2007: 257-298) and Hayek recalls: 'Mises must have lived the First World War with a great deal of intensity. In the 1920 's and 1930's it came out every few minutes in his conversation'(Bien Greaves, 1958b). This continued throughout his life, his stories sometimes even got on the nerves of his wife (Bien Greaves, 1977). In one of his last 
interviews, in 1969, Mises says preventing a Third World War is the most important topical problem (EF: 187). He wrote a lot about war because 'he could not avoid it' (Rappard, 1994: 23). Despite some pacifistic tendencies, deeper analysis reveals far more sophistication in his opinion, and it is evident that Mises became more belligerent over the course of his life.

In principal, there is nothing inevitable about war between certain groups, classes, races or nations. Warfare cannot be seen as the driving force behind social development, otherwise the theory of unsociability would reign in human action (Von Mises, 1996b: 77). However, there is something deeply human about war. It can be satisfying for people, as the desire for bravery and heroism are part of human nature. Attack is a primary initiative and in his feelings man is always an imperialist. Therefore, people must be motivated to contain their feelings (NSE: 213-214). The choice for war is not always irrational, if only because wars have so many different causes. The political decision to wage war may be taken with full account of the (economic) costs involved. Mises points out that pacifists are wrong when they argue that it is impossible for people to gain from war. Individuals, separate nations and states can be enriched by it, if only for a short time and not through a general rise of wealth but by the shifting of wealth (NSE: 152-158, OG: 109). The worst possible motive for war is religion (S: 109), because religious wars are waged without any prospect of conciliation (HA: 179). Differences in language are also an eternal source of friction in international affairs, leading to imperialism and hatred between nations (S: 287, 311-313). Economic nationalism is also a cause of war, as it creates a situation where every citizen has an interest in 'the nullification of interests by which foreign governments injure his interests' and in seeing his own country mighty and powerful, because he expects personal advantage from its military might (MMM: 158-159). Mises' solutions for war and the promotion of peace aim almost exclusively at this economic origin of international conflict, he hardly ever addresses the other causes he distinguishes, which leads to imbalances and inconsistencies in his views on international relations.

Contrary to the opinion of many of his contemporaries, Mises argues that war is not the father of all things. Civilisation is the achievement of the liberal bourgeois spirit, not of war and conquest (HA: 650). His strong economic viewpoint shows clearly in his often repeated assertion that it 
is the state that is responsible for war, especially through its interference in (international) economics. Hence, while acknowledging other possible causes, for Mises the origin of war lies in the anti-capitalistic policies of governments (Butler, 1988: 99-102). Economic nationalism cannot go together with peace, while protectionism is a philosophy of war (HA: 684687). War is not good for business nor the economy (S: 109) and inflation and war are also strongly related. All governments turn to the printing press to cover the costs of warfare (Von Mises, 2006a: 44-45). If men and commodities are prevented from crossing the borderlines, why should the armies not try to pave the way? Mises writes along the lines of Bastiat (HA: 832). The Second World War is therefore the logical outcome of the disastrous political and economic policies of the previous decades (Ebeling, 2000b: xvii).

Modern war is worse, because all people are involved in the fighting (OG: 108). It is ruthless, does not spare pregnant women or infants and lacks respect of the rights of the neutrals. Writing after the bombing of Hiroshima and Nagasaki, he nevertheless asserts that nuclear weapons are not particularly to blame, they are just new, more powerful weapons (HA: 832). Technological advantage must be used against the enemy (S: 207). While Mises agrees with humanitarians that war is detestable because of the death and misery it brings, Mises emphasises that (classical) liberals use a different argument against war. They appeal to the self interest in peace of the warmongers (L: 23-25). Of course, here Mises is inconsistent, as he also asserts that for some people war is perfectly rational, because they can gain from it.

Mises argues only classical liberalism can offer an escape from war (Butler, 1988: 101-104). The ultimate goal of foreign policy is to achieve peace between nations, defined as the perfect, frictionless cooperation of mankind. In this respect, classical liberal thought is cosmopolitan, because it does not stop at borders, nor applies only to limited groups (L: 106107). The main vehicle for peace is the international division of labour. When left completely free, this ensures the greatest welfare for all people and takes out the incentive for aggression. However, reaching this state of peace depends on a change of mind. People need to realise that their best interest is in unhampered international transactions. Mises therefore regards liberal social philosophy as a theory of peace, based on the harmony 
of economic interests between nations (S: 59), which eliminates the rational basis for warfare (NSE: 86). Despite this theoretical optimism, Mises always remains pessimistic about practical political developments. In his own words, written in 1940:

\begin{abstract}
'Occasionally, I entertained the hope that my writings would bear practical fruit and show the way for policy. Constantly I have been looking for evidence of a change in ideology. But I have never allowed myself to be deceived. I have come to realize that my theories explain the degeneration of a great civilization; they do not prevent it. I set out to be a reformer, but only became the historian of decline' (Von Mises, 1978b: 115)
\end{abstract}

Mises thinks that democracy is a way to eliminate both domestic and international conflicts (S: 62), like many current IR theorists argue. His evidence comes from the Manchester School activists, who argued that democracies do not fight wars but settle their affairs peacefully, primarily because they do not care about the size of their territory (HA: 822-823). Mises opposes the idea that democracy alone suffices for peace (L: 108); it also needs unhampered capitalism and a limited state.

Despite his many references to the importance of peace and the futility of war, Mises is certainly no pacifist. He is not convinced by the 'dreamers and humanitarians who have long campaigned for the idea of general and eternal peace'. His objection is these Utopians is that they appeal to the high-mindedness of the rulers. Philanthropic pacifism does not get to the causes of war, nor do 'delusive' appeals for international arbitration. Mises asserts that the liberal pacifism of the Enlightenment is different, it knows no rational basis for warfare because it distinguishes the utility of human conflict. Only liberalism and democracy can accomplish this, hence pacifism not based on a liberal economic order is Utopian (NSE: 85-90).

While he puts a lot of faith in spontaneous processes, it is erroneous to conclude that Mises thinks peace will develop without government action. If all men are good and benevolent there is no need for government, but as this is not the case, it is the government's business to make provisions for war (Hülsmann, 2007: 1025-1026); entrepreneurs cannot do that (Von Mises, 1996a: 27-28). To preserve peace, the state must be prepared to crush the onslaughts of peace breakers (HA: 149, EF: 57). In his 
strongest statement in favour of war, Mises argues that neutrality is unjust in a total war such as Second World War. 'There cannot be any question of neutrality', as this is 'equal to virtual support of Nazism'. Contrasting his own views on the nation, he states that this also goes for all German speaking individuals, either inside or outside the Reich, because 'unlimited solidarity with the linguistic group is one of the main vices of nationalism'. Human cooperation and lasting peace are impossible if individuals place higher value on their loyalty to a particular group above loyalty to humanity, moral law and individual responsibility. The ideals of pacifists and conscientious objectors are noble, but their attitudes 'result in complicity with Nazism'. There is only one way to save civilisation: 'to wipe Nazism of the earth, radically and pitilessly. Only their total destruction will allow the world to start building a good society' (OG: 248-249).

Consistent with his overall economic position Mises is a fierce fighter for free-market warfare, as opposed to the planned and interventionist war economy taken for granted even in capitalist countries. War does not demand a centrally organised economy (NSE: 134-142), because this ruins the economy of the country concerned and makes the transition back to normality after the war harder (Herbener, 1999). It is also nonsensical to aim for economic autarky, both in times of peace and war (HA: 828-830). The title of one of his interwar essays is Autarky: The Road to Misery. It does not prevent war, nor provides economic security (Ebeling, 2002: xlv). Striving for autarky is a threat to European culture, he warned the Germans just before Hitler came to power (Von Mises, 1932). They did not listen, and their desire for autarky was the reason for the Second World War (OG: 78). The market is capable of adjusting to changing demands in times of war, although war and capitalism are not compatible in the long run. There is no use in discussing whether it is fair to make a profit out of the misery of war. Perhaps it is not, but then nothing in war is fair. However, soldiers should have good equipment and the profit system produces the best weapons (HA: 825-828). Against popular opinion Mises holds that the armaments industry is not the cause of war, it only responds to demands by governments. It is preposterous to think that nations turn bellicose for the ordnance of the weapon industry (L: 111). Capitalist countries will always be better prepared and respond more aptly to circumstances of war, 
because of the presence of creativity, which is the basis of the free market economy (HA: 671).

Generally, Mises fails to provide a full analysis of war and peace, which is contrary to his custom when dealing with economic problems. The general pattern of his argument is that after a description of the negative aspects of war, he continues with a plea for the need to fully introduce the international division of labour (see for example L: 25-27). Of course this practice leaves a lot of analytical gaps, owing to his almost exclusive focus on the economic causes of war. For example, it is hard to reconcile his idea about the peaceful effects of the international division of labour with his opinion that frictions between language groups will always remain. $\mathrm{He}$ does not question the validity of his mostly economic arguments, although he admits that waging war might be rational or desirable in the short term. Mises also circumvents, consciously or not, questions arising from his own philosophical views. For example, how should people realise the value of the division of labour and in which way does this overcome all warlike sentiments? How does this relate to his view on human nature? If language and religion are perpetual seeds for war, how exactly are these to be replaced by insight in the value of free trade, democracy and free migration? Finally, there is the more practical, although certainly not simple and still topical question of the definition and limits of self defence. If neutrality is not an option in conflicts like Second World War, then self defence often consists of more than a reaction to an attack by a hostile nation. Despite his strong views on the subject, Mises does not provide a comprehensive answer.

\section{Free trade}

Mises favours almost absolute free trade of goods, capital, services and labour (L: 130-136), which was a minority position in the interwar days, especially in Austria and Germany. With regret he notices that the world does not develop into one big zone of free trade and perpetual peace, unlike the optimistic predictions in the nineteenth century. Instead, there are more customs restrictions and trade barriers (Von Mises, 1925). 
Mises' basic conviction is that there is no superior alternative to the free market system when it comes to increasing productivity. Liberation of trade and stronger economic ties in the world economy must be achieved, most notably through the free movement of labour, which is the best way to deal with different geographical and natural circumstances (Von Mises, 1916). Although military aggression does not lead to economic growth or prosperity (Gordon, 1993: 133), history is a struggle between peaceful free trade and militaristic imperialism, with the latter mostly on the winning side. Where peace is praised or war condemned, rudiments of the argument for the division of labour are found (S: 268).

A world of free trade and free migration no longer has incentives for war and conquest, Mises thinks, in contrast to Hume and Smith and some of his own ideas. A contemporary classical liberal like Röpke (2000: 141-142) agrees that free migration is desirable, yet argues against Mises by pointing out that men do not only act upon rational considerations. Therefore it is an 'unreal assumption to think that in their choice of place of residence man would only be influenced by economic calculations'. Mises is under the spell of Cobden on this point, which shall be elaborated upon in more detail in the next section. However, even Mises does not always endorse free migration. For example, at the end of Second World War he favours restrictions in immigration from the totalitarian states, as this would mean the complete surrender of the West and earlier he warned against immigration in huge numbers, which is seen by the people already living in the area as a threat (Conway, 2004: 87-94).

\section{International Law}

Mises approves of international law that overrules national law to create an equal basis in international affairs (L: 148). Without agreement on the content of international law, there cannot be a working international dispute settlement (NSE: 90). Still, international law is one of the most immature forms of public law, because under certain conditions violence is seen as a solution and revolutions even stand outside its realm (S: 36). It is still a bit primitive in Mises' eyes and he does not write a lot on it. 
Mises clearly stands in the just war tradition. Some wars are just, for example in case of self defence, when hard resistance and everything needed to stop the onslaught is permitted. Brave deeds are justly rewarded and heroic behaviour is rightly extolled and praiseworthy, because they are performed in the service of a good end (L: 24-25). 'Peace breakers should be punished like people who resort to violence within each country' (quoted in Hülsmann, 2007: 810). With approval he notes that in foreign policy 'the value of peace has risen above the profit of a victorious war. Even the strongest rulers respond to the need for a just cause of war. They all attempt to give a valid reason, at least in their view, for war. This is 'a solemn recognition of the principle of law and peace'(S: 58-59).

He also favours the rules in war, which he traces back to the earliest beginnings of society. The rules aim at hurting but no longer simply annihilating humans. After a conflict, renewed co-operation with the former enemy is often desirable, therefore enemies must always be regarded as fellow humans. The result is the current situation where war has become an exception, instead of the normal state of human affairs. Mises concludes from this that 'The Great Society', characterised by rules that embrace all men and nations, is becoming more established (HA: 169-170).

\section{Balance of power}

Mises does not write much about the balance of power, or as he calls it, the European Equilibrium, although he shows a clear understanding of its workings. Despite its heyday in the nineteenth century, the balance of power belongs to the earlier ages (NSE: 32) and is not part of a liberal world of free trade (NSE: 80-85). He changed from this position during the Second World War, when he proposed the formation of two political blocks in global politics, the Western Union and the Eastern Union, which would be 'the only reasonable programme for the defence of civilisation and for a reconstruction of Europe and the whole world' (Von Mises, 2000b: 19). So he somehow anticipated, although never predicted, the formation of the balance of power system during the Cold War. Mises strongly objected to Soviet Russia and its policies in Eastern Europe (Hülsmann, 2007: 805, 908). 
Regarding one of the elements of the balance of power system, international political interventionism, Mises also shifts towards a more positive position. In 1927, he states that the American and European governments should leave Russia to its militaristic self, 'let the Russians be Russians'. They must be prevented from destroying European civilisation, so must be kept behind their borders. Trade with Russia should be free, people should be allowed to migrate and travel, but Western governments should stop promoting the export of capital to Russia [as was the policy then]. Russia should be left alone, its prison camps included, because it does not pose a threat to the West (L: 151-154). Later, Mises shifted his line on foreign intervention. Political isolationism is not an option, he writes in 1943, undoubtedly under the influence of the time, but consistent with his ideas about self defence and war. He feels that the United States in particular cannot hide from world politics. Countering the arguments of the pacifists, he states:

'[the pacifists say] it is very deplorable that the peoples of Europe are fighting each other, that they have wrecked their glorious civilisation and that they are consequently doomed to starvation and misery. It is no less deplorable that similar things happen in Asia. Unfortunately, we cannot save them from disaster. They themselves have to learn that peaceful cooperation would be more beneficial to them than war and mutual extermination. We cannot police the whole world. All we can do is to look out for ourselves and to preserve the Western Hemisphere's independence. We will keep neutral, will not interfere with other continent's affairs and thus preserve our American way of life'

Against this position (which has a lot in common with some of the modern libertarian ideas on international relations), Mises argues that what happens to the rest of the world is of great interest to America. For the sake of its own national interest, the US cannot remain neutral in world affairs and cannot live in political isolation. Every international conflict will involve America too, at least at some point in time. Therefore it must act to establish a peaceful world order, because every nation has to choose, the United States as well (MMM: 153-154). Hence, Mises endorses active engagement of, at least, the US, in establishing international order. 


\section{World Organisation}

The preferred international order of Mises definitely does not include the League of Nations, which he strongly criticises, partly drawing on his own experience as Austrian representative to one of its economic committees (also Hülsmann, 2007: 642). As early as 1919, Mises predicts its failure, expecting it to bring new bloodshed and misery to mankind. The League attempts to divide the world for eternity, between full members and qualified ones and overlooks the difficulties of states with mixed populations. Its authority is built on force to which the disadvantaged must yield, therefore it can never be recognised as a lawful order (NSE: 90-91). Even more fundamentally, solutions for European imperialism and nationalism cannot come from outside, through the action of president Wilson and the United States (Von Mises, 1926). Also, the membership lacks some of the most important nations. People that present the League as the ideal organisation, cause a lot of harm to the idea of a genuine world organisation (L: 147-151). It basically lacks an ideological foundation in liberalism (Von Mises, 1978b: 137) and proposes erroneous solutions for world peace, focussing for example on the redistribution of raw materials, instead of supporting their free movement (Von Mises, 1978a). In the late thirties it is even clearer that the League is a complete failure. The mishandling of the Italian invasion in Abyssinia is its death blow, the crisis shows it has no moral authority at all (Von Mises, 2002a: 309-313).

The only useful roles of the successor of the League, Mises writes in 1944, should be to combat contagious disease, drug trade and prostitution, to act as an international bureau of statistics and to develop work in the field of intellectual property rights (OG: 292-294). The prospects for the United Nations are bad as long as all nations see trade as a zero sum game (HA: 687-688); only classical liberalism could make the world safe for peace and prosperity (Hülsmann, 2007: 830). 'The spirit of conquest cannot be smothered by red tape' of international organisations, treaties and covenants (HA: 825).

Against this background, talk of a world government is futile and illusory, as long as there are great differences in standards of living and civilisation between the nations of the world. The majority of the world population lacks the mentality for peaceful international cooperation. 
What is needed is a change of spirit, but this will take a very long time. The idea of a commonwealth of nations must not be disregarded, but there will be a long transition period (MMM: 161-162). This commonwealth is not a world planning entity, with a unitary form of world government, because that would lead to world socialism. The main danger is that a world government and a world parliament still allow special privileges to certain states, ruling over the underprivileged states, not permitting free migration and so forth. World organisation in this way does not take away the sources of conflict. There is no need for a supranational world government if democracy and free markets rule everywhere (OG: 250-253). This is a change from his earlier opinion, especially in Liberalism (L: 104-154) where he is far more internationalist, even calling for a political organisation that culminates in a world state uniting all nations on an equal basis (L: 148). Although he uses the term nations in the meaning of 'countries' and disapproves of multi-national states, he is more social liberal here than he is in later writings. It seems most likely that the Second World War made him change his mind in this respect.

\section{European integration and supranational organisation}

The run-up to Second World War made Mises more positive about European integration. In the 1920s he still doubts the value of plans for a United States of (Continental) Europe. Given the protectionist economic policies of the European states, Mises agrees that it is in principal a good idea to widen the international division of labour. However, at that time, the champions of Pan-Europe did not favour a liberal programme of the abolition of nationalist thought, chauvinism nor sovereignty. Instead they planned to reconstitute the old militaristic and imperialistic state, but then at the European level, without emotional appeal to its inhabitants (L: 142147).

Mises is also critical about the far reaching and widely debated proposal by Clarence Streit, who favours a federal union of all Western democracies, including the states outside Europe. Mises expects a bureaucratic disaster. A federation always poses the danger of centralised interventionism and planning, as made clear by the US and Switzerland. A federal union 
gives way to the politics of interest groups at the federal level, as it means that national governments have to give up their supremacy in favour of the supranational authority. Yet, no legal constitutional scheme can bypass the sentiments of economic nationalism and love for the state (OG: 278-282). At best, a smaller, Europe-only federation is possible, but even that will be hard if economic nationalism continues to rule (MMM: 162-163).

Later Mises became involved in the movement for a Pan-Europe, lead by Count Coudenhove-Kalergi. In Lisbon, in 1940, Mises spends some time with him, while waiting for a place on a ship bound for America. After his arrival in the US, Mises participates in many of the Pan-Europe Conferences (Von Mises, 1984b: 54-55, 84-85), serves on their Council and as a member of their Economic Committee (Coudenhove-Kalergi, 1944). So, it is not surprising that in Omnipotent Government (1944), he argues strongly in favour of a union of Western [European] democracies, to prevent Europe from slipping back into the interwar modus. They must choose effective solidarity, the idea of national sovereignty should be abandoned in favour of a new supranational authority. His earlier objections no longer apply, which is not strange under the circumstances. In his view, the need for closer integration is obvious for small countries like The Netherlands, Denmark and Norway, who can no longer rely on the balance of power to maintain their independence. Yet he thinks Great Britain and France should also join, while the US, Canada, Australia and New Zealand should closely co-operate with other all other democratic peoples (OG: 276-278). As ever, his support remains conditional. A Pan-Europe must be based on sound economics, without trade barriers and a large bureaucracy (Von Mises, 2000b: 43-49). If the populations still want governmental control over business, all attempts for international co-operation will be rendered futile (Von Mises, 1943). Realistically, he adds that even if these conditions are met, it will still be hard to get the plan working. A lot of national sovereignty of the members must be given up to create a chance for peaceful international relations (Von Mises, 2000b: 15-19, 29), which might be troublesome given the strong emotional tie between individual and nation.

In this respect it is completely consistent that Mises opposes the Marshall Plan (Hülsmann, 2007: 877-878), which many modern commentators regard as one of the important drives behind European integration in 
the 1950s (see for example Dinan, 1994: 16-21). In Mises' view, it is just a good example of wasting American taxpayers money on building deficit railroads and supporting other interventionist schemes. It only differs from charity in that it does not begin at home (EF: 64)! In reviewing his book How can Europe Survive Mises supports Sennholz in his assertion that only the restoration of capitalism and the unhampered free market economy can restore economic prosperity in Europe. As long as that is not the case, American money is wasted (EF: 145-146). Like before, he is alone in this position, the support for the governmental Marshall Plan is overwhelming, even among members of the Mont Pelerin Society (Gillingham, 2003: 18). Hayek founded the MPS in close co-operation with Mises, although Mises would never be completely at ease with a number of members who favoured a greater degree of state intervention than he thought sensible (Hülsmann, 2007: 869-881).

\section{Eastern Europe}

Mises is outright radical, yet inconsistent, in his published and unpublished solutions for the troublesome Eastern half of Europe, and in his plans for Austria's postwar reconstruction (also see Hülsmann, 2007: 723$725,804-805,816-821)$. In his eyes, this region needs a different solution, if another World War is to be prevented. Pre-war economic association between the Danube states failed, because no country was willing to make even the slightest concession (Von Mises, 2002a: 316). Therefore, it is time for something more fundamental. The multi-linguistic character and national rivalry leaves the people of the Eastern Europe at the mercy of the three big adjacent powers, Germany, Russia and Italy. Therefore, a new Eastern European order must be established, with unitary government as the only viable option. Mises calls this state the Eastern Democratic Union, or EDU (OG: 282-290).

In the EDU 'new political standards' need to be implemented. A federation will not suffice, the region should become one political unit. The old organisational units, like the Kingdom of Romania, are allowed to exist, but the importance of their borders shall be reduced to that of the state borders in the US. The major tasks of the EDU are the prevention 
of discrimination against nationality, to enable full freedom of movement for all subjects and to organise a sufficiently strong external defence apparatus which is able to repel the aggression of Germany, Russia or Italy, or a combination of two of them. Economic nationalism must be ruled out, therefore central government has all financial powers, while special commissaries oversee the functioning of the local governments and only private schools are allowed. The appointment of the first president and the first cabinet is in the hands of the League of Nations (Von Mises, 2000b: 169-201).

It is hard to believe that Mises wrote this, but nevertheless he did. Here, he clearly argues against the idea of self determination, which apparently he thinks does not work in Eastern Europe. In a further undermining of his own ideas, Mises makes it clear that differences between nations cannot be overcome by the workings of the international division of labour. The people of Eastern Europe just lack the right mind set and apparently that calls for only one solution: a powerful state. Surely, Mises desires a very liberal state and has the best intentions (Ebeling, 2000b: xxxvii), but as Simons (1944) also notes, his constructivist, top-down planning is evident here.

\section{Imperialism and development aid}

The debate on the future of the colonies is topical in Mises' day. Like Hume and Smith, Mises does not think that everything about colonial rule is bad. For example, Britain has been instrumental in the creation of the modern free trade economy (S: 207) and also enabled a viable Indian state. This territory would otherwise have remained 'a conglomeration of tyrannically misruled petty principalities' engaged in continuous war. India would have been characterised by anarchy, famine and epidemics (OG: 102). Raico does not do full justice to him if he groups Mises among the 'free trade imperialists'. These are thinkers which reject a formal empire, but hold that closed doors for trade should be opened, even forcefully if needed (Raico, 1996: 27). Mises does not think that political empire is acceptable, even if it is the only way to put a system of free trade in place (also Hülsmann, 2007: 303-304). 
Mises general position is one of strong opposition towards imperialism. He argues against treating native people in colonies as means, not ends. Imperialism is in essence a collectivist theory, which rejects individual freedom (NSE: 77-78). The first wave of Western imperialism had often more to do with slavery and piracy than with trade. The nineteenth century conquests were motivated solely by considerations of national pride and military glory (OG: 100-101). Against this Mises puts that there is no wealth creation involved in acquiring new territories, because there are also heavy administrative costs. More importantly, liberals resist all imperialistic plans because these depend on military force, which may also lead to terrible atrocities, such as conducted by the Belgians in the Congo. Mass opinion is wrong in its belief that empire and the preservation of national independence are related. The Europeans should therefore withdraw immediately, even if this causes anarchy in the former colonies. The colonisers have no business in taking care of the interests of the natives, as is often put forward in favour of extended rule. Most colonies are integrated in the European economy, which enables them to gain advantage from trade. Only where this is not yet the case, the Europeans can stay to assure legal and political conditions for entrance in the trade system. Detecting a useful task for the troublesome international organisation, Mises thinks it is better to let the League of Nations govern the colonies during a transitional phase, so the Europeans can move out immediately. All colonies should first become mandates of the League before becoming fully independent (L: 121-130).

After the colonial period, the nations of Africa and Asia should embrace capitalism. However, Mises notes that the contacts with the West have not changed the way the indigenous people think. While they received goods like weapons and medicine straight from the West, this did not modernise their mind set. Mises also rejects plans for state intervention of birth control, because in a free economy people will only have as many children as they can sustain without lowering the standard of living of the whole family. Most importantly, the Africans and Asians did not adapt the key social institutions which enabled the West to develop, like private property, economic freedom, capitalism and entrepreneurial spirit. Capitalism is the only way forward for them, particularly in the light of their population growth rates. What separates East and West is the so- 
cial and economic system. 'It is of no use to import the paraphernalia of capitalism, without admitting capitalism as such'. (HA: 670-672). Both economic theory and history show that laissez-faire is the most successful method to abolish poverty (OG: 256). So there is no need for the West to feel guilty about the circumstances in the underdeveloped nations, given the terrible, collectivist economic policies of their governments, supported by the progressive powers in the West. Dependence on donations is not the solution (EF: 34, 242-243). It is the developing world's economic policy that distracts foreign investment, through foreign exchange control, discriminatory taxation and the nationalisation of industry. Staying out of international capital market creates their plight, there cannot be capitalism without capital. The developing countries need to adopt the policies of 'rugged individualism', not the collectivist doctrines their elites learned at Western universities from Fabian, Marxist or Socialist professors. This only leads to 'occidental pseudo-progressivism'. There is no use in concentrating on a fairer distribution of existing wealth, if you cannot create wealth first. America and Europe have no fault in that, only the bad ideas of the Asian and African elites are to blame. Development aid is therefore nonsensical and will not create prosperity. Only a change in policy can be of help (MMM: 166-173, OG: 290-292). No doubt, were Mises still alive, he would be happy with the current achievements of most Asian countries, but would see his ideas confirmed by the bad state of affairs in most SubSaharan countries.

To sum up, Mises' ideas on international relations start with the individual and the special place he has for his nation. Nationalism, both political and economic, is one of the biggest threats to the establishment of peace, which can be created through the implementation of the division of labour and unhampered free movement of goods, services, capital and people. While the prevention of war is his leading motive, he is no pacifist nor an isolationist. There are just grounds for war and he endorses the just rules for warfare. Mises argues for more international societal co-operation between national states, most notably in Europe. World wide international organisations are of limited use and a revolutionary overhaul of the world system is Utopian and not needed. International law is a defunct, but in itself helpful institution to smooth the functioning of the international society consisting of states. Mises clearly opposes imperialism and develop- 
ment aid. As a result of the dominance of his economic analysis, his politics are not always consistent and despite his life long interest in international affairs, Mises fails to provide a full analysis of international affairs, working bottom up from his philosophical premises, even though it is clear all his writings are directed towards widening the scope for individual freedom.

\section{Mises and International Relations Theory}

With his strong faith in the peaceful effects of trade and the division of labour, Mises clearly differs from Hume and Smith, although he regularly, but often erroneously, refers to them. For example, he mistakenly claims that classical liberalism has always been pacifistic and anti-militaristic (NSE: 3), that Smith's philosophy was one of peace between nations (OG: 147), or that the classical liberals have full confidence in man's 'perfectibility' (OG: 295). Like many other liberals, he seems to have 'been obscured by the nineteenth century association of economic liberalism with pacific sympathies' (Winch, 1978: 104). Mises shows a very clear understanding of the classical liberal tradition in other fields, therefore the other sources of his international relations demand more analysis. This way, their effect on his views on international relations is determined before a comparison with the traditions of the English School is made.

\section{The origins of Mises' ideas about international relations}

Mises makes clear his ideas on international relations are influenced by both eighteenth and nineteenth century liberals. Next to Hume and Smith, he most frequently mentions Bentham, Ricardo, Bastiat, Cobden and other Manchester School thinkers. With the exception of Bentham, whose writings on international relations mostly were written at the end of the eighteenth century, these are influential nineteenth century theorists and activists.

Jeremy Bentham coined the word 'international'. His reputation as an IR theorist is mostly based on his essay $A$ Plan for an Universal and Perpetual Peace, which is actually a product of inadequate editorship by 
John Bowring, who composed it out of three different essays, after Bentham's death. During the 1780s, Bentham writes on international topics in several essays, and drafts an international law code in 1830. Not all of his writings are properly analysed, so Bentham is often erroneously seen as a liberal international theorist, on the basis of his idea that commerce leads to peace and his support of international law (Hoogensen, 2005: 89, 40-54), and his rejection of most wars (Howard, 2004: 35). These are exactly the elements that Mises takes from Bentham, basing himself on the German translation of a section of Bentham's collected works entitled Principles of International Law (NSE: 86). Of course, it is not fair to judge Mises on the basis of research published after his death. It is important to note that Bentham's thoughts on international relations also contain many arguments that are not shared by Mises. For instance, Bentham's overriding concern for security, which he regards as the most important goal of public policy. He also proposes a 'common tribunal' or a formal international organisation as a solution for international conflict and as an alternative to war. This is sometimes seen as a main inspirational source for the League of Nations, so despised by Mises. Briefly put, Bentham's overall position on international relations is a mixed bag, with a lot of realist elements (Hoogensen, 2005: 12, 86-89, 194-195), many of them contrary to Mises' outlook. He is not resolutely anti-imperialistic, although unlike his followers James and John Stuart Mill, he is not a supporter of colonialism either (Pitts, 2005: 103-122). Hence, Mises clearly follows the mainstream interpretation of Bentham's international relations, without going into much detail of his actual writings.

Ricardo is not often seen as a political thinker, although he had a short spell as Member of Parliament, between 1819-1823. His writings are mostly on technical economics and if the international area is touched upon it is also in a strict economic fashion. Ricardo is not a wide ranging scholar and has no 'well-mediated, articulate, all embracing social and moral philosophy'. He was first of all a businessman, who later turned to politics. He may be regarded an economic liberal in line with Adam Smith (Winch, 1996: 409-416). The utilitarians Bentham and Mill were keen to count him among their members, but he was not much interested in their social philosophy (Taylor, 1960: 172-186). He did claim that free trade 'binds together, by one common tie of interest and intercourse, the uni- 
versal society of nations throughout the civilized world' (cited in Zacher and Matthew, 1995: 114), and he was a strong opponent of the Corn Laws (Irwin, 1996: 93-94). It seems likely that Mises mostly admired Ricardo for his economic work, especially the comparative advantage model of international trade.

The most important sources for Mises' views on international relations are the works of Cobden and the Manchester School (Hülsmann, 2007: 737), therefore their ideas will be examined in more detail. During the Second World War, Mises writes that only the return to Manchesterism enables humankind to safeguard peaceful relations between individuals and nations, although he did not expect this to happen very soon (OG: 10). He takes its unity for granted, but in fact there was no such thing as one Manchester School, it was a group of different people, without a coherent philosophy or a common doctrine. It was an expression of middle class Radicalism, originating in Manchester, with the core formed by the Anti-Corn Law League (Grammp, 1960: 1-6, 16-38, 46-47, 114), so it was more of a single issue group.

The League associates itself with the idea of the alleged link between (unilateral) free trade and peace (Ebeling, 2003a:248-253). Their line of argument is as follows: trade represents the advantageous exchange of mutual abundance and to the extent that commerce is allowed to proceed freely, the economic interests of nations become increasingly mutually interdependent. The reciprocal dependency on free trade reduces quarrels and breaks down the political and cultural barriers that separate states. $\mathrm{Mu}-$ tual interest and dependence binds people together and this results in permanent and universal peace. Many Leaguers also believe that trade spreads civilisation and Christianity. A number of them, Cobden included, are devout Dissenting Christians, so for them there is also an element of moral crusade involved. Representing the middle class they distrust the landed class, which is supposed to have an interest in warfare. Diplomats and military commanders are seen as related to the protectionist aristocrats and the land owning higher classes. Not surprisingly, there are also close ties between the League and the pacifist movement, which mainly consists of the Quakers and the Peace Society. They all share the desire for non-intervention and the opposition to the balance of power doctrine (Spall, 1985: 237-251). There are many possible objections to the idea that commerce 
and peace are related, which shall be discussed in more detail in chapter seven. For now it suffices to note that some contemporaries, like Malthus, immediately objected to this idea. They emphasised that states, just like people, are at times governed less by interest than by passion (Grammp, 1960: 24), which gives lots of other causes for war. Mises noted this as well, but preferred to passionately defend the position of the Manchester School.

It is striking that Mises, an ardent anti-pacifist, draws the main inspiration for his international relations from a group of mainly pacifists. This anomaly becomes even clearer if we look at the political thought of Cobden, the most famous Manchester School representative. His overall political philosophy can be characterised as 'altruistic utilitarianism', aimed at the transformation of the relations between nations, arguing that . foreign policy must have a higher and more humane purpose (Dawson, 1926: 8082). The military and markets are substitutes, more of the first means less of the second, and vice versa. The expansion or protection of commerce can never be a just ground for war and foreign nations should always be left to sort out whatever problem they have between themselves (Stringham, 2004). Cobden readily acknowledges Adam Smith as the greatest single influence on his thought. He hopes that all over England Smithian Societies will be founded, devoted to the promulgation 'of the beneficent truth's of the Wealth of Nations'. Contrary to Mises, he is not very supportive of democracy (Hammarlund, 2005: 91) and he also favours international arbitration (Cobden, 1978).

Foremost, Cobden is a man of action. He is no deep thinker, but a brilliant orator and politician. He is no laissez-faire liberal, given his support for many acts of government interference in the life of individuals. According to Grammp he also opposes the complete free international movement of capital. Cobden's argument for free trade is not just about a linear relation between peace and free trade. His contention is that trade creates international specialisation, which in turn prevents a nation from becoming self sufficient enough to wage a war. 'Free trade unites two remote communities by the strongest of motives of which our nature is susceptible, rendering the interest of the one the only true policy of the other, and making each equally anxious for the prosperity and happiness of both'. Free trade takes away the power from governments to plunge their people 
into wars (Grammp, 1960: 100-105). Mises' argument differs a little from this, he holds that the international division of labour makes peace inevitable, through the inherently peaceful nature of commercial exchange. Free trade takes away the ground for warfare, such as the desire for territorial conquest, because there is no gain from it (Von Mises, 2006b: 34).

Cobden fundamentally deviates from Smith, by arguing that harmony between states is possible (Dunne, 2005: 190). As early as the 1830's Cobden is a pacifist and a member of the Peace Society. He endorses Bentham's definition of war as 'mischief on the largest scale' and rejects most wars (Rogers, 1873: 109-110), but he keeps a distance from people who repudiate war in any case, defensive or offensive and contends that war is sometimes needed, for example in defence of our honour, or our just interests' (Cobden, 1978: 374-375). It is claimed by some scholars that pacifism is Cobden's ruling purpose. 'The man who has been held up as the tribune of laissez-faire was in fact not governed by economic purposes at all' (Grammp, 1960: 13-14, 110-101, 234-235). Hirst confirms Cobden's pacifism, and points to his devotion to discredit the balance of power, to limit the cost of army and navy, to his support for international arbitration and his pleas for non-intervention in the affairs of other nations, including the colonies (Hirst, 1968: ix-xix). In his first publication England, Ireland, and America (1835), Cobden favourably refers to Smith's colonial politics, especially his doubts about the profitableness and the wisdom of imperialism. Cobden even states that Smith would support his position on colonialism and free trade (Chesson, 1903: 25), which is actually very doubtful.

Cobden opposes loans to the Russians which enable them to procure armaments. 'No free trade in cutting throats' he says. In the 1920s, Mises would argue in favour of the full incorporation of Russia in the international economy. Over the Crimean War Cobden breaks with Wilson, the founder of The Economist. Together with John Bright, another leader of the Manchester School, he opposes the war, against strong popular sentiment. This event teaches them some lessons, as it turns out they erroneously counted on the populace and public opinion to refute war, on the commercial class to influence policy towards peace, and were wrong to expect that only the old ruling classes are inclined to belligerent acts (Howard, 2004: 41-51). In 1857, Cobden and Bright cause the fall of the Palmerston government 
over the British misbehaviour in the Opium Wars against China. At the subsequent elections, they both (temporarily) lose their seats in the House of Commons. In sharp contrast, Mises later defends the English (S: 207). Cobden also rejects the American Civil War, favouring the separation into two nations. Unlike Bright and Mises, who think war is inevitable in some cases, Cobden is 'near to believing in complete non-violent resistance in all conflicts and for a practising politician, he is remarkably consistent in public as well' (Grammp, 1960: 117-128). Yet there is controversy on this point, because Cobden is also on record denying that he is a total pacifist (Cobden, 1978; Howard, 2004: 42).

Bastiat is an early admirer of Cobden and writes a book about him and the League. They become friends when he visits him in London and Manchester, in 1845. Bastiat is indebted to Cobden for his activism, while Cobden takes many theoretical insights from Bastiat (Morley, 1903: 309311) and his support for natural law, natural rights and the idea of the harmony of individuals groups and states through the free market (Rothbard, 2006a: 448). This latter is Bastiat's basic idea, he argues men's interests are not antagonistic, but in harmony. Cobden and Bastiat agree on most political and philosophical issues, for example on the need for international disarmament (Russell, 1969: 17-29, 42, 73, 114) and non-interventionism in foreign affairs. Bastiat (2007: 517-529) despises war, which he blames on the human propensity to plunder and to take advantage of a stronger position. Instead, he advocates free trade and limited government as ideal means for attaining lasting peace and genuine freedom. According to Roche, 'he made no divide between abstract and unreal segments such as political man or economic men, unlike the utilitarians', nor did he predict a Utopian heaven on earth (Roche, 1971: 120, 194-195), although one can easily object to this because of his 'trade means peace' position.

This brief overview makes clear that Mises did not analyse the ideas of his sources in detail. Apparently, he was not aware that they held views contrary to his own. His prime focus was on their international economics, and a selection of their international political ideas. He does not give evidence of anything but the most superficial knowledge of their ideas about international relations. This is clearly not characteristic of Mises, but it does explain some of the inconsistencies in his own international relations, 
despite the fact he devotes so much time and effort to thinking about international affairs. Given the many positive references to them throughout his works, it is all the more remarkable that he once said: 'the optimism of Bentham, Cobden and Bastiat was not justified, they were liberal Utopians' (Von Mises, 2000b: 4-5). To do justice to him, this was during a talk for the Yale Economic Club on 22 May 1941, shortly after Mises' arrival in America. More fundamentally, his own ideas about the relation between the division of labour and peace appear as Utopian, as shall be elaborated upon in the next chapters.

\section{Mises and the Three Traditions}

One looks mostly in vain for references to Mises in modern IR literature. His work on international relations is neglected by IR scholars and even by most of his followers. The most prominent reference is a short review of Omnipotent Government in Foreign Affairs in April 1945. Here his work is received with badly hidden distaste and the assertion that it will 'become the source of considerable controversy', because of its uncompromising and unitary explanation of the rise of Nazism by statism, 'and thus it is subject to serious discount'. More recently, Mayall (1990: 159) refers to Mises as a passionate defender of liberalism in a nationalist and imperialist world, but he only does this in an endnote. Jackson (2007b: 63-64) is the exception, by referring to his ideas on sovereignty. Nevertheless, there is no image to correct, in contrast to the two previous chapters, simply because Mises is not a serious actor in IR theory. This neglect is most likely due to the general disapproval he met among academics, economists included, but his often half-hearted international relations analysis probably did not help either.

When comparing Mises' international thought to the characteristics of the three traditions, it is clear that he is no realist. Much of his work on international politics is directed against the power politics of Germany and the other great European powers. He prefers an international order consisting of states, however the national government's power must be limited to its own territory (MMM: 158). While he teaches at New York University at the same time as Morgenthau, he is certainly not influenced by him (or 
vice versa, for that matter). Mises strongly rejects imperialism in general and the German conquest for Lebensraum in particular. His support for the balance of power is at best half hearted, although he had good insight into its workings and its relevance in the past, especially for the survival of small states. His rejection of offensive war also makes him unfit for classification as a realist.

At first sight, Mises and the Kantians are a much better match. They share a desire for perpetual peace and the freedom of movement for labour, capital, people and goods. Of course, Mises' conviction that the international division of labour will be able to bring perpetual peace has a Kantian touch, while he also endorses forms of supranational organisation. Yet, he rejects this type of solutions at the world level, he associates pleas for a one world state with Marx and Lenin (Von Mises, 2006b: 32) and is in general not a great fan of Kant's philosophy (Hülsmann, 2007: 42). Mises regards Kant's categorical imperative as a foundation for socialism and thinks Kant's ethics are weak compared to Ferguson and Smith. Socialists are neoKantians, who do no better than their master (S: 388-389). He finds Kant's proposal to prohibit the raising of loans for waging war extremely naïve, because as long as war is considered advantageous, no rules will prevent its outbreak (Von Mises, 1981b: 433).

Mises is also unimpressed by twentieth century liberal internationalism, widely seen as one of the main expressions of Kantian international thought (see chapter seven). For example, President Wilson wrongly assumes that only autocratic governments are warlike and democracies inherently peaceful, because they do not see any value in conquest. Mises asserts this is only true in a system of private ownership and free market. In his view, the pacifists have never addressed the root cause of nationalism, which is etatism, the trend toward government control of business. The creation of a new international bureaucracy is definitely not a solution (OG: 5-6). His other objections against the League of Nations were discussed above. So it is also no wonder Mises opposes Norman Angell, one of the most famous interwar international theorists, and a strong supporter of the League (Miller, 1995: 101). Mises finds his plans for peace too abstract, leaning towards day dreaming, and he accuses Angell of completely missing the economic nationalist dimension of world affairs (MMM: 160). He may have added Angell's strict political rationalism, but ironically, Mises 
and Angell share a belief in the peaceful effects of interdependence and both refute nationalism (Miller, 1995: 103-121). With modern Kantians Mises is at odds over the international role of capitalism and issues such as development aid. Hence, while acknowledging some Kantian traces in Mises' ideas about international relations, most notably on the issue of war, is it still a bridge too far to consider him a Kantian.

While the case for Mises as a Grotian is not as clear as those of Hume and Smith, it is still the most convincing option within the English School framework. The basis for this is formed by his endorsement of the institutions of the international society of states. He writes with approval of Bodin's theory of national sovereignty, as well as Grotius' theory of war and peace. Both thinkers promote the peaceful co-existence of sovereign states and the age of limited warfare, while opposing boundless conquest (HA: 821-822). Except for Eastern Europe, Mises clearly envisions that a commonwealth of free nations is the best international order to start with in Western Europe (Von Mises, 2000b: 183). One also searches in vain for plans which promote a revolutionary overhaul of international organisation. His adherence to the nation, as a collection of individuals, is strong. Even though he points to its defects, international law is valued, especially the rules of warfare. He is no pacifist, but requires a just basis for war, which is fully in line with Hume and Smith and the wider just war tradition. Mises only seems to deviate on the importance of the balance of power, which he mostly ignores. His disapproval of international organisations and development aid is greater than is common among modern international society theorists, but of course these scholars are hardly ever classical liberals. In fact, Mises greatest contribution to Grotian international relations is his plea for the limited state and unhampered capitalism. 


\section{6 \\ Friedrich Hayek, International Order and Federalism}

Most likely, Friedrich August von Hayek (1899-1992) was the most important classical liberal of the twentieth century. A Nobel Prize winning economist who turned to political and legal philosophy, he also wrote about theoretical psychology (Hayek, 1976) and the history of ideas (see for example Hayek, 1979). Together with his mentor Mises, he is widely regarded as one of the most important intellectuals who took up the fight against socialism. He started the important classical liberal Mont Pelerin Society and actively supported think tanks and public policy institutes around the world. Among others, he influenced Margaret Thatcher, Ronald Reagan and, less well known, the German politician Franz Josef Strauss (Cubitt, 2006: 47-48). He felt that a chief task of the economic theorist or political philosopher was to influence public opinion, in order to attempt to change political impossibilities into realities. Objections to his proposals did not deter him in the least from developing them (Hayek, 1990: 17). Hayek was a full professor most of his life, at the LSE, Chicago, Freiburg and Salzburg. Compared to Mises he was more a public face of classical liberalism, joined by Milton Friedman after the Second World War. Hayek waged 'a war of ideas' and lived long enough to enjoy victory, after the Cold War ended with the collapse of communism (see for more biographical details Leube, 1984; Cubitt, 2006; Ebenstein, 2001; Caldwell, 2004; Ebenstein, 2003; Butler, 1985; Nishiyama, 1984).

Current Hayek and Mises-scholars tend to make much of the differences between them. One of their main disputes was whether socialism and planning would fail due to the impossibility of calculating prices, or whether the human mind would be able to process the enormous amount 
of information needed. Their differences partly originate from the influence of Wieser on Hayek's economics, for example in his views on money and capital theory. Also, Hayek did not think economic knowledge was a priori and he saw more room for state intervention in society (Caldwell, 2004: 143-149, 220-231; Hülsmann, 2007: 464-479, 701-719). Other differences for example were on the question of the reintroduction of the monetary gold standard, especially during the Great Depression of the late 1920s and early 1930s. Mises thought this should be done immediately, while Hayek, who supported the gold standard in principal, argued this would create more difficulties than it would solve. They also argued about the number of state tasks, with Hayek defending more state involvement in the life of individuals, especially in the third part of The Constitution of Liberty. As will become clear, these divides are also apparent in their ideas on international relations, but should nevertheless not be exaggerated. Mises regarded Hayek as his best pupil (Von Mises, 1984b: 41) and Hayek said he learned more from Mises than from any other man, although he characterised their relationship as 'curious'(Hayek, 1994: 68). By and large, they were good friends engaged in the same fight against collectivism (Hülsmann, 2007: 700-701, 707).

\section{Hayek and classical liberalism}

Not many people doubt that Hayek should be regarded a classical liberal as defined in this thesis, therefore this section shall be brief. Hayek's political philosophy is a combination of the emphasis on free markets, limited government, individual liberty, the encouragement of personal moral restraint and respect for tradition and religion (Feser, 2006: 5). His ideas are almost identical to the characteristics of classical liberalism described in the second chapter. Moreover, he explicitly refers to the classical liberal tradition as his intellectual guiding light and his wish to restate its 'old truths' in the battle against the twin ideas of socialism and totalitarianism. In Hayek's view, there is no need for a new theory of liberalism, because the principles of the earlier version are as valid as ever before (Kukathas, 2006: 192). Hayek acknowledges the influence of Bernard Mandeville (Hayek, 1978d: 249266), yet most roots of his ideas are found in the Scottish Enlightenment 
(Hayek, 1994: 140) The influence of Hume is especially profound (Ebenstein, 2003: 100; Hayek, 1979: 1; Hayek, 1967: 106-121) and he also admires Smith (Hayek, 1978d: 267-269; Smith, 2006: 97-135). Despite a few differences on technical economics, Hayek and Smith generally have the same outlook on order in society (Haakonssen and Winch, 2006: 374378). This also shows in plain numbers: in his philosophical books, Smith and Hume are the authors most often referred to by Hayek (Ebenstein, 2001: 187). There is some debate about the extent of Kantian influence on Hayek (see Gray, 1998; Shearmur, 1996), or even whether his liberal philosophical inheritance is an unhappy mix of Kant and Hume (Kukathas, 1989: 20-45; Roos, 1994). Hayek himself saw only an indirect influence of Kant on his thought (Hayek, 1994: 139-140).

The individual and the safeguarding of individual liberty is the central tenet in Hayek's political philosophy (Hayek, 1993: 205-219, CL). In his social theory the individual only has imperfect knowledge and is not the imaginary rational economic man. In contrast, humans are prone to be lazy, improvident and wasteful, although not necessarily selfish. All human action is based on people's opinions, subjective perceptions and beliefs. A key Hayekian insight is that knowledge is dispersed among many people, no individual is omnipotent. Actions of people have intended and unintended consequences, which all contribute to social reality (Caldwell, 2004: 241-247, 281-287). An individual is free when he is not coerced, which Hayek defines as independent of the arbitrary will of another. Complete freedom is not possible, as living together always depends on compliance with a minimum set of general rules. Ideas to minimise coercion and to maximise the individual's negative liberty through safeguarding of a large private sphere, are at the centre of Hayek's writings (CL: 11-13). He realises that the rule of law is very significant for accomplishing this and hence wrote a lot about legal questions.

Hayek clearly fits into the non-religious, Humean natural law tradition. He denies that positive law, or legislation, could ever be a source of real law (Van Dun, 1994; Cliteur, 2000), and rejects notions of religious transcendence in his ethics (Walker, 1986: 35). Hayek asserts that freedom can only be guaranteed under the rule of law, just like thinkers from the Ancient Greeks and the Romans, to Locke and the Scots (Dietze, 1976: 107-115). He is certainly not utilitarian in a Benthamian sense, but like 
Hume, Smith and Mises he tends to explain certain traditions and institutions on the basis of their apparent social utility.

His view on society stands clearly in the Scottish tradition. Order develops spontaneously, it is the unintended result of the non-rationalistic, non-planned behaviour of individuals, using their fragmented knowledge to make the most of their lives (Gray, 1998: 27-55). Hayek is particularly keen to clarify that the application of the idea of spontaneous order extends beyond the market order, most notably encompassing morals, traditions, customs and the development of languages.

Freedom cannot be secured by spontaneous order alone, because not all human behaviour is benevolent. The state is necessary to maintain societal order, most importantly through the protection of property rights. The state should be small, yet strong (Haakonssen, 1985), but to others, like Mises and many libertarians, his list of allowable state tasks, such as the provision of a minimal form of social security, education, and urban planning (see CL: 253-394), leaves too much room for government involvement in the life of individuals. Indeed, Hayek is rather inconclusive about how to distinguish between justified piecemeal social engineering and outright rational constructivism (Roos, 1994: 290). Nevertheless, in general his classical liberal economic credentials are not in doubt, he favoured the application of the free market in most policies. Like the public choice economists he repeatedly warned against the influence of special interests on the state. The (British) trade unions are among his main targets (Tomlinson, 1990: 87-96), a passion he shared with Margaret Thatcher, who he repeatedly sent letters of advise on this issue (Cubitt, 2006: 49).

\section{Hayek's ideas on international relations}

Hayek was first drawn to the problems of political organisation during the first World War, when he serves in an Austrian regiment where eleven languages were spoken. In his view the related problem of nationalism is the main reason for the collapse of the Austro-Hungarian empire (Hayek, 1994: 48). So, it was international affairs that stimulate Hayek to start thinking about politics. In his youth he intended to join the diplomatic academy, but found it was no longer interesting after the empire no longer 
existed (Hayek, 1994: 48). Later, he repeatedly expresses the wish to write more about international affairs (see Hayek, 1998: III, 149, LLL), and always shows concern for the international context of his ideas (Hayek, 1992: 239). However, Hayek's contributions on this topic are mainly found in chapters, articles in periodicals and, significantly, newspaper coeditorials. Hayek's major organisational contribution to international relations is the MPS, his post-war attempt to facilitate exchange between the often isolated classical liberals in all countries, not least from Germany. The MPS must be counted among Hayek's lasting impact on the global revival of classical liberal ideas (see Feulner, 1999; Hartwell, 1995).

\section{Nation and nationalism}

The nation, somewhat narrowly described by Hayek as 'a homogenous community', is an important element of individual identity. Although he once spoke of the 'myth of nationality', his overall position is that nationalities are a prime source of group organisation and individual loyalty. With Gellner (1997: 1) he shares the idea of the power of common culture, defined as 'a shared style of expression in words, facial expressions, body language, style of clothing, preparation and consumption of food, and so forth'. Consequently, people do not tolerate longstanding domination by groups of a different nationality (Hayek, 1948: 264, IEO). Hayek thinks existing states are often imperfect because they have heterogeneous populations (CL: 105) and like Mises regards federalisation as the preferred solution. He never endorses the organisation of the world along strict national lines, although he thinks states, or in his words 'sovereign nations', are the ultimate units of international order (Curzon Price, 1996: 315). Human bondage depends as much on culture as on geographical nearness. Like Smith, Hayek notices that we have a lesser emotional bond with or feelings of responsibility for people that live far away. We may be moved by the misery of the millions of unfortunates, yet we cannot make our abstract knowledge of them a guide to our everyday behaviour (CL: 84).

National characters are manifestations of rules governing both the actions and the perceptions of the people. These can be represented by concrete symbols, like a flag or a shrine or the person of a monarch or 
leader, and can also contain abstract rules defining what is done, or not, in a particular society (LLL, II: 12). Hayek sometimes uses national character to describe nations. In fact, he is sometimes 'culturally insensitive and stereotypical of particular nationalities', for example when talking about his Bengali students (Ebenstein, 2001: 294, 390), when he once referred to 'dancing Negroes', or sometimes even his beloved Japanese (Cubitt, 2006: 23-24). On the other hand, he is much concerned about the generalisations about Germans and Germany among the British population in the 1930s and 1940s (Shearmur, 2006: 156-159). He is not allowed to join the British war efforts, so, in vain, offers to assist the BBC and the Ministry of Information in their propaganda efforts, especially to address this issue (Caldwell, 2007: 9-15). Later, he calls upon the readers of The Road to Serfdom to recognise that Germans are not inherently vicious (Hayek, 1997a: 5, 9-10, RS). Compared to Britain or France, Germany has more difficulties being a national state, due to its dispersed geography, history and culture. There are many regional German identities, but there is hardly cultural homogeneity at the national scale (Hayek, 1992: 219-236). In fact, the nationalists attempts, from Bismarck onwards, to create a German nation is a principal factor in the outbreak of the World Wars.

Hence, while the nation must be valued, nationalism is poison (Hayek, 1967: 143). The roots of the nationalist development can be found in the struggle for national freedom, or the application of the freedom concept to a collective. There are important differences between national freedom and individual freedom. History shows that striving for the former may not promote the latter at all (CL: 14-15). Hayek repeatedly criticises the nineteenth century liberals, especially Mill, for joining forces with the nationalists (IEO: 270, especially note 9; LLL: II, 134). Nationalism is closely related to the false rationalist liberalism of the Continent, with its centralising and socialist leanings (IEO: 28).

There is also a direct relationship between nationalism, imperialism and socialism. Most planners are militant nationalists (SW: 218), because they think that foreign contacts hinder the effective organisation of society. Arguing against his former employers, Hayek notes that the founders of the London School of Economics, Sydney and Beatrice Webb, are prominent examples, with their preference for large and powerful 'administrative' states, and their contempt for smaller ones. This glorification of power al- 
most inevitably leads from socialism to nationalism (RS: 106-107). When one's state is seen as superior to others, it is a small step to depart on a civilising mission. Patriotism, in Hayek's view 'the deep attachment to national traditions', is different and not dangerous, as it can easily go together with aversion to nationalism.

Instead, for Hayek, liberalism and internationalism are positively related. Ideas respect no boundaries, and people should make an effort to become acquainted with new ideas, even if only to counter them. It is wrong to dismiss an idea because it is perceived as un-American, or un-German. He underlines: 'my personal position makes me unable to sympathise with any form of nationalism' (CL: 405-406).

\section{War and international security}

Like Mises, Hayek is no pacifist, nor does he ever regard war as a regular foreign policy instrument. With Hume and Smith, he regards war as inevitable. During Second World War, he is understandably most firm in his opinions. He states that 'the first task is to win the war' (RS: 9). His bottom line is that without safety, there can be no liberty (IEO: 270). Accordingly, the prevention of war and civil strife ought to take precedence over all public measures (IEO: 270-72), and even the most sacred principles of a free society, like individual liberty, may be temporarily sacrificed during a war (CL: 217; LLL: III, 124). For Hayek, the provision of external defence is an essential role of the state (Barry, 1994: 154), which requires it to have certain coercive powers, like the capacity to raise taxes and the ability to recruit an army in times of emergency (Butler, 1985: 107). Ebenstein (2001: 225) states Hayek even approved of military conscription, but fails to provide evidence for this. On the basis of the writings analysed for this thesis it must be concluded that there are no references to support this claim. If Ebenstein is right, it would make Hayek a clear exception to the classical liberal prohibition of state coercion in military recruitment.

In line with his support of federation (to be discussed below), Hayek never regards defence as the exclusive realm of each separate state. There may be real advantages in the pooling of resources. For example, in the nineteen thirties Hayek is eager to try to prevent the outbreak of war. 
Diplomatic measures may be of importance in this respect and therefore he proposes a system of mutual armaments control in Europe, (Hayek, 1997b: 161, SW). In the nineteen seventies, Hayek writes positively about NATO. By relying on this supranational defence organisation, the North American and Western European members have excluded the possibility of war against each other. Additionally, supranational cooperation may even lead to decentralisation of the national state, because preparations for war are often strong centralising forces in domestic politics (LLL: III, 132).

In common with Mises and Smith, and in this particular case even with Keynes (Skidelsky, 2006: 97-99), Hayek also looks at war as an economic problem. Partly in opposition to the Austrian economist Otto Neurath and his followers (Caldwell, 2006: 27), Hayek favours non-intervention in the war economy. Hence, there should be no inefficient governmental control of raw materials, imports, private consumption, capital market, interference in capital flows or interest rates, et cetera (SW: 151-160, 164-172; RS: 153, 155). Hayek argues that economic planning fails in both times of peace and war.

As a lifelong and frequent contributor to the public debate, Hayek publishes a significant number of his views on specific foreign policy issues in newspaper co-editorials, especially after he received his Nobel Prize. Compared to other classical liberals and libertarians, he is actually rather hawkish in his comments. Some examples from the end of the 1970s and early 1980s are telling. He publicly supports President Reagan's level of defence expenditure, saying that world peace depends on America staying strong. Hayek doubts that the Soviets would start a nuclear war, but underlines that they will not hesitate to use a position of military superiority against the West. Therefore the West must be at least as strong as the Soviet Union (Ebenstein, 2001: 300-301). He expresses strong support for the Western boycott of the 1980 Moscow Olympics (Hennecke, 2000: 350 ) and endorses the policy of nuclear deterrence. He believes it promotes peace, stating ' $I$ have indeed from the first moment that nuclear bombs have been used, been confident that I would not see another major war in my life time' (quoted in Hennecke, 2000: 342). Hayek criticises the American government for failing to act more belligerently in the Iran-hostage case, arguing that 
'peaceful international relations and the safety of persons in foreign countries would have been much better served if the US had at once sent an ultimatum saying that, unless every single member of the embassy staff were within forty-eight hours handed over unharmed [..], bombs would be falling at an increasing rate at the seat of the Iranian Government'.

Likewise, during the Falklands War, he writes that the Argentine government broke many long standing rules of international law, which fully justified a British counter-attack. He proposes to permanently station a submarine in the South Atlantic to destroy Argentine weaponry when deemed necessary (Hennecke, 2000: 347). According to Charlotte Cubitt, his long time secretary, he thought that President Carter was a fool for trying to solve the Iran-conflict peacefully. In general, Hayek is much in favour of immediate military action to solve international conflict, although he found the US attack on Libya in 1986 'alarming'. He is personally excited about warfare, and regards pacifism as the cause of war. He spoke fondly of his own war experiences and recalled with disgust the many fellow officers that used the first available excuse to return to Vienna (Cubitt, 2006: 47, 204). All in all, Hayek is consistently arguing that individual liberty fully depends on the maintenance of international order.

\section{Federation}

Hayek is equally consistent about the value of federalism, in cases where regular states cannot function well. In his view, the major advantages are that federations limit central governmental power (Shenfield, 1961: 54), curb majority power in general (RS: 163) and enable heterogeneous populations to live together in peace.

In the 1930s, when prospects of a new war loom ever larger, the merits of federalism were widely discussed. Hayek is one of its most ardent defenders. He is an early supporter of several different federal plans, for example by his LSE colleague Lionel Robbins, the Streit-plan (see previous chapter) and Hayek even endorses Angell's idea to federally unite France and England. When it becomes clear that war cannot be avoided by such a limited federation, Hayek goes a step further and proposes, like Churchill 
and Monnet would, full economic and political union between the two countries as the best way to win the war. Federation is also the only viable solution for polyglot Central Europe: 'if federation was not desirable for other reasons, it would have to be invented' [for this region, EvdH]. Yet to keep the European balance of power and to prevent German domination, a Central European federation must be extended to include France, perhaps the Northern European countries and certainly Britain. The British need to assure French security concerns and must therefore overcome their 'false pride' and face the restrictions on national sovereignty that a real rule of international law undoubtedly brings (SW: 161-164). During the Second World War he lowers his ambitions and writes that federal union may only work in a small number of Continental Western European countries. Eventually it may be expanded, while some form of co-operation with the British Commonwealth and the United States is possible and preferable (RS: 176). Hence, Hayek firmly believes in supranational co-operation between states, but not in a Kantian way. He analyses international society with full regard to and appreciation of the balance of power.

In 1939, Hayek states that 'the abrogation of national sovereignties and the creation of an effective international order of law is a necessary complement and the logical consummation of the liberal programme'. This must lead to 'neither Staatenbund nor Einheitsstaat, but a Bundesstaat' (IEO: 269-270). He does not argue for the abolishment of national states, nor advocates a world government. His goal is interstate federation, or a Union, which in his view is a classical liberal correction to the erroneous nationalist path taken by the nineteenth century liberals (IEO: 270-271). Federation brings peace between its parts, and less conflict between the federation and other states. The latter, not so much due to any inherently peaceful external effects of federations, but simply because a military strong federation eliminates the danger of outside attack (IEO: 255), so again Hayek employs a balance of power argument.

Political and economic union must go together, there are no examples of successful common foreign and defence policies without economic union. Foreign policy by a federal Union presumes central control over all international issues, including economic ones, because these can also be a cause of war. Internal economic barriers hinder the best use of available resources, especially in the area of defence, where internal fragmentation 
directly weakens the military might of the federation (IEO: 256-257). Another major advantage of a federation is that it makes economic nationalism and economic planning practically impossible. As long as a laissez-faire policy is in place, the economic power at the central level remains limited. A devolution of powers to local units enables competition between local communities, and ensures that there is no favourable treatment of one group over another (IEO: 256-268). Hayek thinks that people of one state are not willing to support strangers if some planning authority would order them to. He asserts that there are no common ideals of distributive justice. Hence his rhetorical question 'which Dutch worker would be willing to pay more for his bicycle to help the Coventry mechanic?' (RS: 164-167). Ironically, the modern European Union practice is that the desire for international wealth redistribution is much greater than Hayek held possible or would approve of.

The main task of the federal government is to say 'no' to measures that entail possible harm to the constituent parts (RS: 172). Given his pleas for such a limited federation, it is somewhat puzzling that Hayek recommends the ideas of the socialist Ivor Jennings (RS: 173). In a concise book the latter also discards ideas about an intercontinental international organisation, limiting his federation to Western Europe. It's main function would be to act as a brake on nationalism, while the federation must have powers over defence and foreign affairs. However, he also proposes a degree of control over colonies and all kinds of governmental interference (Jennings, 1940), which clearly contradicts Hayek's ideas.

Even though post-1945 Europe did not develop into his proposed federation, Hayek remains an advocate of federalism. Most notably, he advocates the federalisation of Jerusalem. He says the fate of the city is a cause dear to his heart, as he 'has followed the Jewish aspirations with sympathy'. He is worried by the threats to Israel's existence, for example by Yasser Arafat, whom he regards as a terrorist leader not worth to be spoken to by Western leaders (Hennecke, 2000: 346). Between 1978 and 1985 he writes several letters to the Israeli politicians Moshe Dayan, Teddy Kolek and Menachem Begin (Hayek, 1978b; Hayek, 1980). His suggestion is to make Jerusalem the capital of a Royal Palestine, or a Levantine Federation, which would include Israel, East Jordan, the West Bank, Gaza and possibly Lebanon. Jerusalem would be like Washington, District of Columbia, with 
assured free access for all citizens of the member states. The scheme would make Jerusalem permanently Israeli, but not only Israeli. He claims this idea has ripened since his visit to Israel in 1968, although he acknowledges that his Israeli friends are very sceptical (Hayek, 1982a). He warns the Israelis that if they do not act themselves, the idea might be forced upon them by others. He contends that this plan is 'a suggestion of crucial importance $[. .$. . which offers the unique possibility, in the long run, to the unswerving support of the whole Christian world for the preservation of Israel' (Hayek, 1981b). He only gets polite, though firmly negative Israeli responses, which presses him to send his plan to the editor of The Times (Hayek, 1985), although he had initially hoped that somebody else could go public with it, for example the Israeli prime minister in a speech to the Knesset.

As Shearmur points out in a more general context (1996: 53-60), it questionable whether this Hayekian preference for the creation of federations is rather constructivist. At first sight this seems plausible, but against it must be recognised Hayek only proposes institutional changes when the regular states fail, often due to strong and destructive nationalist politics and economics. Many forces then prevent the spontaneous formation of order, which leads to a clear threat to individual liberty. Only in such cases does he distinguish a need to look for other options, which are always restricted to the establishment of a classical liberal, limited state.

\section{International organisation and international law}

Hayek gives grounds for confusion about his ideas on global international organisation. On the one hand, he suggests that a European federation could be expanded to a larger group of states, 'and perhaps' one single global federation (RS: 174-175). In 1950, he even proposes the admission of the individual German states and other Western European countries into a Union with America (Ebenstein, 2001: 391, n. 16). Sometimes he also favourably refers to a 'universal peaceful order'. On the other hand, he argues forcefully against political or economic organisation beyond unions of national states. For example, in The Road to Serfdom he also dismisses 'the silly claims made on behalf of a federal organisation of the whole world, 
during the height of the propaganda for a Federal Union' [in the 1930s and 1940s, EvdH]. For him, there is no need, nor obvious merit, to fuse different countries in a single centralised state (RS: 173). There should be no super state with (economic) powers, if only because human kind has not even learned how to control these powers in the national sphere (RS: 172). Indeed, Hayek says 'until I find a sane person who seriously believes that the European races will voluntarily submit to their standard of life and rate of progress being determined by a World Parliament, I cannot regard such plans as anything but absurd'.

He also expects these other races to refuse to submit to a white race dominated world (RS: 166, note 2). Hence, Skidelsky (2006: 100), is erroneous in his assertion that 'Hayek thought that a world government would be needed to entrench economic liberalism internationally'.

Hayek is not in favour of an omnipotent and comprehensive global organisation. He regards this as an international expression of rationalist constructivism. The creation of all kinds of international organisations actually leads to more conflict (Hayek, 1968: 41-42). At the end of the Second World War, he warns against the creation of a new League of $\mathrm{Na}$ tions. Like Mises, Hayek thinks the League's span of control was too big, it lacked power and geographically it was too dispersed. 'While we must aim at preventing future wars as much as possible, we must not believe that we can at one stroke create a permanent organisation which will make war in any part of the world entirely impossible' (RS: 176).

In the 1970s, he argues that the United Nations is ineffective and constructivist. This is not remarkable given his view on its origins. Partly inspired by the reports of some members of the drafting committee, like the Marxists Laski and Carr, Hayek argues that the Universal Declaration of Human Rights is 'an attempt to fuse the rights of the Western liberal tradition with the altogether different tradition deriving from the Marxist Russian Revolution', which adds ill-defined, absurd and unenforceable social and economic rights to the traditional negative rights portfolio (LLL: II, 104-106). It is therefore tragic that the General Assembly of the United Nations, 'the most comprehensive authority which man has yet created' proclaimed that 'everybody should keep the Declaration constantly in mind'. This undermines the respect it ought to command and shows that the Assembly 'indulges in the self-deception that we can at the same time 
benefit from the spontaneous forces of society and mould them to our own will' (Hayek, 1966; Hoy, 1984: 49). This type of criticism Hayek actually shares with Martin Wight (Hall, 2006b: 127-129), although there is no indication that the two influenced each other.

It is wrong to regard human rights as positive claims, both domestically and internationally. 'Nobody has a right to a particular state of affairs, unless it is the duty of someone to bring it about or preserve it'. For example parents have a duty to take care of their child and people have equal political rights. While it may be preferable to live in a world where all people have governments protecting certain human rights, this is not enforceable. The world is a loose society, not an organisation resulting from Platonic rationalist constructivism (Hayek, 1966). Therefore, attempts to ensure peace through international organisation commence from the wrong end. Large specialised organisations, with particular tasks cannot do the job, so it is no surprise Hayek has for example a low opinion of the International Labour Office (LLL: II, 105). True international law limits the powers of national governments to harm each other. 'If the highest common values are negatives, not only the highest common rules, but also the highest authority should essentially be limited to prohibitions' (LLL: III, 149). Hayek believes in the power of international law, but becomes increasingly critical about its development. The concepts of sovereignty and state are kidnapped by the positivists, which makes it impossible to develop this true international law (LLL: II, 61).

In The Constitution of Liberty, Hayek, rather vaguely and certainly inconsistently, points out that questions of international relations require different philosophical foundations than domestic politics. There is no moral foundation for the establishment of an international rule of law comparable to the rule of law in national politics. Also, problems in international relations are hard to solve as long as states are the ultimate actors at this political level. It is not at all clear what he means by this, because generally his own views on international relations are consistent with his domestic political philosophy and he certainly does not argue against states as actors in world politics either. Hayek continues by arguing that transfers of 'the new powers of governments' (by which he means any power that goes beyond the classical tasks of the state in a laissez-faire situation) to supranational agencies are a danger to individual freedom. Only makeshift 
solutions are possible at the international level, because people have not yet discovered rules to effectively limit governmental powers, nor how to divide these powers between the several levels of authority. He states that until the protection of individual liberty is much more firmly secured than it is now [in 1960, EvdH], the creation of a world state would probably be a greater danger to the future of civilisation than even war' (CL: 262263).

Hayek remains generally positive on international law as such, as is clear in a joint letter with Karl Popper to President Reagan, on 11 February 1981. They request Reagan to subject a certain, unnamed but topical issue to the International Court at The Hague, arguing that this would satisfy all kinds of 'crucial requirements', would lead to prompt drastic action and the cooling down of feelings. They also anticipate that this would lead to a formal restatement of 'a basic doctrine of international law, without which a return to normal relations would be impossible' (Hayek, 1981c). The subject of their concern is not named, and is not easy to detect either. Most likely it concerns the rocket crisis between Syria and Israel in South Lebanon, and not, like Hennecke argues, the Iran hostage affair. This latter crisis ended on 20 January, a few hours after Reagan's inauguration, and the International Court of Justice had already ruled in US favour in May 1980 .

Despite all his writings in favour of negative individual rights, Hayek does not always promote them in his personal behaviour. He toured South Africa, despite his regret that the Dutch reactionary Afrikaners took the lead in the country, instead of the English speaking liberals (Ebeling, 1977: 12). Hayek thinks its racial policies unjust and wrong, but nevertheless publicly argues that the international community holds in many ways scandalous double standards towards South Africa. He doubts the wisdom of the weapon embargo and, most relevant here, wonders aloud whether the international community can enforce its own moral standards upon South Africa (Hayek, 1977). In 1977 and 1981 he also goes to Chile, which he regards as a great economic success and he also defends its government. Although it is an authoritarian state, the totalitarian Allendeperiod was much worse, Hayek argues. He is convinced of an ongoing campaign against Chile led by Western countries, and feels harassed by public opinion and organisations such as Amnesty International for lectur- 
ing in the country, just like Milton Friedman after he advised the Chilean government. Hayek complains that no social scientist ever gets that sort of treatment when visiting China, Libya, Algeria or Uganda. He argues that (economic) sanctions should be based on the violation of clear and published international rules, not just on public outrage. The United Nations can only hope to regain influence when it stops acting arbitrarily, as it does in this case (Hayek, 1977). In 1982, he even protests against the publication of a political cartoon in the Frankfurter Allgemeine Zeitung, where the Polish and Chilean regimes are presented as equally wrong. Hayek argues that any Pole able to flee to Chile would be very lucky (Hayek, 1982b). He also sends this piece to Margaret Thatcher, but to his great disappointment she rebuffs him by responding that Chile had indeed gone through some economic success, but that some of its other policies were entirely unacceptable (Cubitt, 2006: 19).

Hayek chooses to support or at least to remain neutral to the political sides of these regimes, even when these clearly clash with his own ideas about individual political liberty. His general position is that democracy is the best political system, but that it is still possible to protect personal freedom in less perfect countries, like Singapore, Liechtenstein, or Chile (Hayek, 1978c). He cares far more about the economic developments, possibly because he is excited to see his own recommendations implemented. Hayek is displeased by the less critical reaction by world opinion leaders to human rights abuses in the communist countries. He also wants to remain loyal to his often long standing personal contacts in Chile and South Africa. In addition, he so used to forms of public outrage and contempt for his ideas, that he is not impressed by the protests of students or non-governmental organisations (see also Hennecke, 2000: 348-351), and in this case not even by many protests from his friends (Cubitt, 2006: 19, 200). Yet, this does not change the inconsistency between his words and deeds.

\section{Imperialism and development}

Hayek does not write much about imperialism, but generally favours decolonisation (IEO: 269), on both political and economic grounds. British colonial rule has shown that even mild forms of planning known as 'colo- 
nial development' lead to the imposition of ideals and values other than those of the people concerned (RS: 166, note 1). He never endorses foreign domination of other states as a legitimate policy objective, nor argues against decolonisation.

From the 1960s until his death, he is more involved in questions of the (economic) development of the newly independent states, partly under influence of the path breaking work on development economics (2003), by MPS member Peter Bauer. Like Mises, Hayek thinks it is problematic that the leaders of developing countries are influenced by collectivist ideas during their education in the West (CL: 3). Bad economics keeps poor countries poor. For example, artificial increases of the speed of industrialisation at the cost of agricultural production lead to food shortages for industrial workers. The forced copying of successes elsewhere is just another variant of governmental planning. Only free economic growth is likely to enable development (CL: 322, 366-367). Global richness also brings greater technological innovation, which directly helps to reduce poverty and misery. Indirectly, many countries who lack freedom can in this way still benefit from the freedom of others. The world population is a 'captive of progress', in that it has experienced the abolition of starvation, filth and disease, and rapidly expansion of its numbers, which are all sustained by sufficient economic growth (CL: 48-53).

Hayek warns against the idea of a need, or a right to international redistribution of wealth. 'There exists neither on the national nor international level a moral ground why poorer regions should be entitled to tap for their purposes the wealth of richer regions'. He notes with disgust that 'the silly race [for political influence, EvdH] with Russia' makes the West also dole out favours to the socialist experiments of underdeveloped countries (LLL: III, 133).

Not surprisingly, Hayek strongly rejects the 1980 'Brandt report', of the Independent Commission for International Developmental Issues chaired by the former German Chancellor. Hayek thinks it is 'flawed', because it supports the 'traditional fallacy that poverty can be cured by a massive transfer of wealth'. Somewhat surprisingly he does not argue against all aid, but instead proposes market-based solutions, like government guaranteed loans by private lenders (Hayek, 1981a). Only countries that want to become capitalist are entitled to Western support, all others should turn 
to Russia for assistance. Overall, the Brandt report is 'dummes Geschwätz. Er zeugt von einer derartigen Ignoranz der tatsächlichen Probleme, dass es schon ein Skandal ist' (Baron, 1981).

There is controversy about Hayek's last work, The Fatal Conceit, because of the alleged 'overgenerous editing' by William Bartley. However, Ebenstein (2003: 221) concludes after detailed analysis that the chapter entitled 'The Extended Order and Population Growth' is genuine Hayekian. In a world of specialisation and division of labour, growing numbers of people lead to increased productivity, which actually enables further population growth for an indefinite period of time. The related economic growth is beneficial to the poor, it enables them to stay alive, raise children and see to all kinds of other needs. Capitalism indeed gives life. Without it, the poor are worse off. The developed world

\begin{abstract}
'morally, has as little right to prevent the growth of population in other parts of the world, as we have a duty to assist it. On the other hand, a moral conflict may indeed arise if materially advanced countries continue to assist and indeed even subsidise the growth of population in regions, such as perhaps the Sahel zone in Central Africa, where there appears to exist little prospect that its present population, let alone an increased one, will in the foreseeable future be able to maintain itself by its own efforts'
\end{abstract}

Hayek thinks it is partly due to Western interference that populations can grow beyond the point of natural feeding capacity. In the long run, development aid will not have any results. The use of resources by a larger world population is not a problem, therefore the Club of Rome and their supporters are doomsayers. Populations anywhere have the right to development and the West has no right to idealise the primitive life of the nondeveloped peoples, nor to limit their desire for modernisation. The increase in population in large cities in the underdeveloped world stems from the fact that people living in the shanty towns already reap the benefits of urban economic development, but still cling to a traditional lifestyle, by keeping a large family to provide for them in old age. 'Whatever men live for, today most live only because of the market order' (Hayek, 1991: 120-134). In this last passage the influence of Julian Simon, the environmental economist, is also evident. In 1981, Hayek wrote to him: 'I have never before written a fan letter to a professional colleague, but to discover that you have 
in your Economics of Population Growth provided the empirical evidence for what with me is the result of a life-time of theoretical speculation, is to exiting an experience not to share with you' (Simon, 1996: 614-615). It is clear that only a sufficient amount of freedom is able too bring further development and prosperity. Hayek recognises that numerous examples of partially free states around the globe show that even a limited expansion of freedom already brings greater prosperity (Curzon Price, 1996: 308-311).

\section{International economics}

Hayek is a convinced free trader (Hayek, 1994: 115). Trade and the growth of civilisation are positively related. Government interference in trade is seldom to any benefit and must therefore be avoided (Hayek, 1991: 3847). All international economic barriers must be abolished to achieve the highest material welfare for all the people in the world (Ebenstein, 2001: 98). Despite his critical attitude towards international organisations, he is positive about the removal of trade barriers in the General Agreement on Tariffs and Trade (GATT) and even 'in some measure the intentions, if not the practice' of the European Economic Communities. Both helped to create the 'Great Prosperity' of the post-war period (Hayek, 1978d: 106, 131; Kotterman-van de Vosse, 1994: 94). Like Mises, Hayek asserts that governmental economic nationalism often leads to war.

International economic planning can only be accomplished by the naked rule of force, laid down by a small group of people who impose their views on millions of others. 'The Grossraumwirtschaft can only be realised by a Herrenvolk', a master race. The chances for international order, or lasting peace, are small as long as every country employs zero sum policies, aimed at its own immediate interests, without regard of its external effects. That international economic relations are a matter of states instead of individuals, 'must end in clashes of power'(RS: 163-167). Territorial barriers lead to protection of (economic) benefits by certain groups (IEO: 257), like trade unions, which are typically the first to call for justice nationally, but are protectionist internationally (LLL, II 90).

Like for Mises, Hayek thinks free immigration is the ultimate ideal. However, he is afraid about the destabilising effects of large groups of im- 
migrants entering a relatively homogeneous territory. This would most likely lead to nationalist reactions and a retreat from friendlier positions towards newcomers, which he strongly rejects. His opinion is based on lessons he drew from the great influx of Jewish peasants from Galicia and Poland, that caused racial resentment and anti-semitism among even the most decent Viennese people. In his view:

'however far modern man accepts in principle the ideal that the same rule should apply to all men, in fact he does concede it only to those whom he regards as similar to himself and only slowly learns to extend the range of those he does accept as his likes. There is little legislation can do to speed up this process and much it may do to reverse it by re-awakening sentiments that are already on the wane'

This causes Hayek to publicly support Thatcher's call to stop immigration (Hayek, 1978c). In the public uproar that followed (Cubitt, 2006: 27) he tries to clarify himself. First, he rejects the accusation that he thinks racialism is the fault of the victim, restating that 'regrettably' experience showed that ordinary man only slowly reconciles himself to a large increase of foreigners among his neighbours, even when these people only differ in language and manner. Therefore to prevent an unpleasant reawakening of primitive instincts, the wise statesman ought to aim at keeping the influx low (Hayek, 1978e). Second, he repeats that acculturation is a slow process, which may almost stop when the new groups of immigrants are large enough to form their own communities, which to Hayek's regret is almost universally resented by the indigenous population (Hayek, 1978a). This is fully in line with his concerns about movements that want 'to keep foreigners out' for economic reasons (Butler, 1985: 97). Hayek favours free immigration in principle, but clearly distinguishes the possible, yet regrettable negative social effects this may have for the people concerned.

Hayek's idea of a nation clearly does not comprise emotional ties to the national currency. In the late 1930s, Hayek warns against monetary nationalism and the existence of national currencies (Hayek, 1999: $37-$ 105). Later in his career, he proposes the full denationalisation of money, due to his general opposition to the economic and monetary influence of governments and their central banks (Desai, 2006: 72). He calls for the absolute freedom to use currencies of all nations in each others territories 
(Hayek, 1978d: 225), and the abolition of any kind of exchange control, or the regulation of the free flow of money in the broadest sense between the rich countries. Only then inflation can be curbed, 'honest money' provided, and the governmental monopoly of the issue and control of money terminated (Hayek, 1990: 23-24). The British government tried in vain to implement this idea in the 1980s (Thatcher, 1993: 716), in order to prevent the introduction of what Hayek calls the 'Utopian European Monetary Unit' (1994: 151), as he does not expect the members to be able to agree on the common monetary authority's policies, nor that they will be able to administer a new currency any better than they did their old ones (Hayek, 1990: 24). Some classical liberals are still on this line (see for example Gillingham, 2006: 55-110; Ebeling, 2007).

\section{Free Trade and Peace}

In contrast to Mises, Hayek hardly discusses the alleged peaceful effects of trade. Gissurarson's claim (1985: 12) that he consistently argues that trade leads to peace is wrong though. At most Hayek is ambivalent about this idea. As indicated previously and to be further discussed in the next chapter, the idea that trade promotes peace is rather popular among different liberals, many of them in some way influenced by Hayek. Therefore, the relation between free trade, peace and Hayekian thought is now analysed in more detail.

Hayek starts with the idea that the emergence and development of trade is a general model for the development of rules and order in society. Trade rules regulate conduct independent of the particular purposes of the people concerned. The order so formed may eventually, Hayek is careful never to predict a certain outcome, enable the development of a universal peaceful order. His ideal is the establishment of the nomocracy, or the purposeless, law-governed society, as opposed to the telocracy, the purpose governed system. Only in a nomocracy the possibility for peaceful co-existence can be extended beyond small groups of people, like families, herds, tribes, et cetera. This type of order grows spontaneously through the process of natural selection. Hayek calls this ideal order the Great Society (like Smith), the Open Society (like Popper), or the 'extended order'. In 
it, all people are able to pursue their own purposes in peace (Hayek, 1967: 168). While he mainly describes the Great Society in terms of domestic politics, he contends, albeit without further clarification, that its formation 'produced at least the beginnings of a world society' (Hayek, 1967: 163165).

Trade has the character of a non-personal exchange, and it takes place on the basis of a common interest between the people involved to voluntarily truck and barter. Both sides gain from the exchange, otherwise there would be no trade at all. This can be labelled as the 'standard Hayekian model' of human action. Individuals are not required to agree on ends, the agreement on means suffices to enable their collaboration (LLL, II: 3). Therefore, free trade may be a model for international spontaneous order. While never clear on it, Hayek seems to expect positive spill-over effects from trade into other areas of international relations. More trade means greater prosperity and a larger degree of interdependence in international relations. It may limit the desire for war, because the individuals involved have a larger interest in keeping peace.

However, here Hayek starts contradicting himself. To apply his own terms: at the international level there is often a need to agree on ends, rather than means alone. International politics is more a zero sum game, which implies that there are numerous situations where rules do not, or only partially, exist. Hayek is aware of that in numerous parts of his writings. He clearly fails to show how free trade facilitates international rules to develop spontaneously. More importantly, it is hard to imagine that Hayek really thinks trade could ever be able to accomplish international peace, given his view on human nature. Hayek and the other classical liberals consider humans as inherently social. They cannot function without each other, they are not egoistic atoms, solely concerned with their own interests. Sometimes people, due to their 'Humean enslavement by the passions' are prone to prefer the short term quick win over the long term wise decision. Humans are also inclined, though not destined, to act wrongfully in a moral sense. Hayek himself points at the imperfections of human knowledge. Therefore, in the classical liberal view of human nature there are many grounds for disagreement, arguments and fights among people. In domestic situations this can partly be solved by agreements on means, the dispersion of private property, the protection of personal liberty and 
the implementation of the rule of law, mostly through government action. The international arena is different, not least because the mutual feeling of sympathy cannot be stretched without limits. Like Hume and Smith, Hayek believes that people in 'small groups' have strong feelings for one another, while in the 'extended order' affection and bondage is less strong (Smith, 2006: 132). In the Great Society, the effect of a person's actions on others is largely unknown and there are less duties towards other people. The principle of limited but equal treatment of all men is probably the only chance for peace (LLL: II, 90-91). At the same time Hayek emphasises that the greatest obstacles to a universal application of rules of just conduct are still the individual's loyalty to class, occupational groups, clan, nation, race or religion. Hayek states that special rules which explicitly permit to hurt a stranger if that is beneficial to the own group, only slowly make place for rudimentary general rules of international law, which enable the Great Society to develop and even 'offers the distant hope of a universal order of peace' (LLL: II, 148, 151-152).

Peace, one of Hayek's 'three great negatives', together with freedom and justice, must be the result of rules of civilisation (LLL: III, 130-131). But this does not go well with the insights summed up before. Since humans are least attracted to strangers, there are greater chances for animosity between the leaders of states. State action is human action. This does not mean there must be international disagreement all the time, or that peace is not worth striving for. Yet in the Hayekian view conflict and war are inevitable. Human nature simply implies the occurrence of conflict and war, and trade is unable to overcome that. If one accepts that Hayek flirted with the 'trade leads to peace thesis', it must be recognised that this clearly contradicts his own philosophical position and his opinions on international affairs, like the belief in the value of the nation, the inevitability of war, his support of the balance of power, international society, federation and forms of international law, and his rejection of development aid.

\section{Hayek and IR Theory}

Hayek's work is not often mentioned in IR, not even in pieces on international liberalism. Sometimes his general or economic ideas are touched 
upon, although seldom in a positive way (see for example Williams, 2006a: $58,118)$. Only a few exceptions deal with his ideas on international relations. Easley and Wilson rightly count him among the prominent federalists of the 1930s and 1940s (Easley, 2004: 136), while Young (1989: 8485 ) takes his idea of spontaneous order into account when explaining the formation of international regimes, explicitly linking spontaneous order and the balance of power mechanism. Richardson is probably the most prolific writer on Hayek, he portrays him as a ruthless anti-state thinker, unresponsive to calls for international justice. He links him to realism, owing to Hayek's alleged desire to exclude ethical considerations from international relations (Richardson, 2001: 43-44, 82-83, 155, 161). In his book on liberal international relations, Ashworth misrepresents Hayek' ideas on domestic and international affairs in an almost malicious attack. For example, he erroneously claims that Hayek rejected Christian morality, that he 'assumes that planning sets out to understand society in its complex whole' or that he lacks sophistication when pointing to positive outcomes of market relations (Ashworth, 1999: 86-88). Of the Hayek scholars, Curzon-Price (1996: 299, 308) underestimates the extent to which Hayek directly addressed problems of international relations and Ebenstein (2001: 300-305) just mentions some of his newspaper articles on foreign policy. By far the most detailed and well researched overview is provided by Hennecke (2000: 341-359), but he does not give any theoretical context.

Hayek is not very clear about the sources of his ideas on international relations. Unlike Mises, he seems not much influenced by the Manchester School, although he praises their position on free trade (Hayek, 1978d: 129). Besides Hume and Smith, he generally refers most to Lord Acton and Tocqueville, in his view the two leading nineteenth century representatives of true individualism and liberalism (Hayek, 1948: 28). To distinguish whether they had some influence on Hayek's international thought, a closer look into their own views on this topic is needed.

\section{The influence of Acton}

Before focussing on the ideas they share, it must be noted that Hayek and Acton differ on many issues. For example, Acton is not convinced of the 
value of private property (Fasnacht, 1952: 59-60), he favours aristocracy rather than democracy, is not attracted to the US and only half-heartedly objects to slavery. Not surprisingly for an aristocrat, Acton describes Cobden's views as 'essentially a bourgeois way of looking at things' which is not meant as a compliment. He laments the importance the Manchester Liberals attach to property, money and land and apparently also thinks Adam Smith is biased towards materialism (Himmelfarb, 1952: 9, 178, 182).

However, like Hayek, Acton considers himself an old Whig fighting for the principles of freedom and liberalism, opposing state absolutism and socialism (Fasnacht, 1952: 83, 117). They share a dislike of historicism, the idea that history purposely leads to a certain goal in the present (Himmelfarb, 1952: 204). Acton also thinks it worthwhile to engage in a war for twenty years, if the ideal is the establishment of international law (Himmelfarb, 1952: 216). Both men hold Burke in great regard for his anti-rationalism and his preference for societal evolutionism. In this respect it is worth noting that Burke's ideas on international relations are characterised by strong pleas for respect for international community, especially in Europe. He also appreciates war and the balance of power, and disregards issues such as state sovereignty and international non-intervention (see Vincent, 1984; Fidler and Welsh, 1999; Boucher, 1991). However, in contrast to Hume and Smith, Burke initially strongly rejects independence of the American colonies (Winch, 1996: 137-141) in order to keep the ties of community between Britain and America, but when English defeat was inevitable he stands for American independence, as keeping the empire united is ultimately of lesser importance to Burke than American freedom (Fidler and Welsh, 1999: 13-18).

In the field of international relations Hayek and Acton share an appreciation for the use of national characters (Acton, 1985b: 431) as well as a strong dislike of Mill's nationalism and imperialism (Kukathas, 2006: 198). Acton's general emphasis is on the negative side of nationalism (Acton, 1985a: 560) and virtually alone among his contemporaries, Acton foresaw that nationalism would become very dangerous, as it only leads to moral and material ruin (Hill, 2000: 411-412). The nation, defined as an ethnic group, is an essential, but not supreme element in heterogeneous states. A single state comprising one nation becomes primitively barbarian. The best states for Acton are pluralist and contain many races and nation- 
alities without repressing any of them (Himmelfarb, 1952: 69-87).

The origin of the idea of the ultimate value of popular sovereignty goes back to the French revolution. Since then, tradition is no longer the guardian of authority, but the dangerous theories of equality, communism and nationality (Acton, 1985b: 409-414). There were more than forty copies of Machiavelli's Il Principe in Acton's library, but that was not out of admiration. He often links the nationalist movement with this Italian philosopher (Hill, 2000: 414). Hayek and Acton share a resentment of realpolitik but they differ in that Acton becomes more pacific and anti-imperial later in life, whereas Hayek remains rather hawkish (Muller, 2002: 386). Both men also oppose imperialism. Acton disapproves of English imperialism, opposes its behaviour in India and Africa and supports Irish Home Rule later in his career (Hill, 2000: 415-416).

Is seems likely that Acton influenced Hayek's view on the relationship between liberalism and nationalism. In the Continental liberal tradition the nation is seen as a principle of unity, ultimately giving way to the Millian idea that the boundaries of the state and the nation must coincide (Acton, 1985b: 422). Opposed to that is the English nationalist tradition, where liberty is the ultimate end of the state, not class, national interest or the greatest happiness of the greatest number (Fasnacht, 1952: 127-131; Acton, 1985b: 424-426). Acton also favours the development of a world of federal democracies (Hill, 2000: 415; Acton, 1985a: 559), which is his most obvious influence on Hayek. The clearest sign of this is the epigraph opening the chapter on international relations in The Road to Serfdom, which is a quote of Acton on precisely that topic (RS: 163). Hence, despite their differences, Acton and Hayek have a lot of ideas in common. While acknowledging the lack of much hard evidence, it seems reasonable to suspect at least a pattern of influence.

\section{The influence of Tocqueville}

Hayek and Tocqueville share a number of convictions on domestic politics, but the analysis of their opinion in international affairs is not easy, because Tocqueville changed his mind rather radically on this matter. As a parliamentarian he started out rather bellicose (De Tocqueville, 1994: 264), but 
during his short spell as foreign minister, in 1849, he became an advocate of international peace and diplomatic dispute settlement (Clinton, 2003: 17). Hence, it is hard to speak of 'the' Tocquevillean position on international relations. The overview below will therefore be limited to a comprehensive listing of different and common positions, as a full contextual analysis is beyond the purpose here.

Tocqueville certainly does not believe in a relation between commerce and peace, contrary to many of his contemporaries (Boesche, 1987: 218). $\mathrm{He}$ 'does not wish to speak ill of war', and likewise distinguishes positive traits associated with war, like the opportunity for personal merit and military grandeur. Commenting on the Crimean War, Tocqueville is enthusiastic about soldierly courage and stresses the importance of national glory resulting from war (Boesche, 1987: 63-65). He also speaks in terms of national character, which results from the early stages of nation formation (De Tocqueville, 1994: 27). He defends nationalism, in his view it unifies and transcends differences (Wolin, 2001: 534) and he is also an ardent defender of imperialism, which he calls 'heroic' and 'able to capture the national spirit' (Clinton, 2003: 27). Tocqueville is concerned with the effects of democracy on foreign affairs, as he fears a weakening of the state due to the short term electoral pressures on the leaders, that easily overrule long term strategic interests (Lively, 1962: 106)

More in line with Hayek is Tocqueville's warning that wars and administrative centralisation often go together. 'All warlike spirits love centralisation, which adds to their forces, and all centralising spirits like war, which obliges nations to grant to the state a monopoly of authority' (Lively, 1962: 156-157). States should also behave with a certain morality and respect for international rules (Boesche, 1987: 216-218). Like Hayek, he thinks that 'the interests of the human race are much better served by giving every man a particular fatherland, than by trying to inflame his passions for the whole of humanity'(Clinton, 2003: 22).. In the turmoil of the revolutions of 1848 , his goal is to 'oppose the international revolutionary side of the movement towards democracy, but foster liberal institutions within states' (Clinton, 2003: 33). Another common position is (the older) Tocqueville's preference for the development of an international society of nations, which is the ideal international order, especially in Europe. He even refers to 'the natural law among nations' and favours institutionalised 
common standards of conduct, which includes the duty to keep the balance of power (Clinton, 2003: 28-32). Even though they agree on some points, it is not really possible to establish a clear pattern of Tocquevillean influence on Hayek's ideas on international relations, partly owing to the inconsistencies in the thought of the Frenchman.

\section{The three traditions: Realism}

Compared to Mises, Hayek is much easier to classify in terms of the three traditions of the English School. He is clearly not a realist, as he generally refutes realpolitik (RS: 174), and calls Hobbes' 'primitive individualism in the state of nature' 'a myth'. He does not believe there was ever a war of all against all (Hayek, 1991: 12). Hayek does not shy away from war, but endorses it only as a reaction to unjust conduct by others. He never treats it as a regular political instrument. Imperialism is wrong and there is certainly a role for morality in international politics.

Hayek's anti-realism shows most clearly in his strong criticism of E.H. Carr, the prominent realist of the interwar period. He calls him 'one of the totalitarians in our midst', and particularly refutes Carr's ideas about the subordinate position of morality in world politics, compared to political calculation and expediency (Gamble, 1996: 90-91). To Hayek's dislike, no rule is safe in realism, nor pacta sunt servanda a moral imperative. He strongly opposes this forfeit of general principles and underlines that international treaties should have practical meaning and be morally binding. Hayek even accuses Carr of arguing that England fought the First World War on the wrong side and thinks he sympathises with Carl Schmitt, 'the leading Nazi theoretician of totalitarianism'. In addition, Hayek rejects Carr's assertion in Conditions of Peace, that war is the 'most powerful instrument of social solidarity, with a clear sense of meaning and purpose, as well as Carr's 'pitying' of the 'well meaning English people' in their nineteenth century belief that war is without purpose or meaning (RS: 138141). A few years later, in a review of Carr's Nationalism and After, Hayek notices some improvements in his 'collectivist thinking', but argues that Carr is too optimistic about the strength of nationalism (SW: 251-253). 
Hayek favours some of the realist convictions though. Besides his view on human nature, his personal conduct towards South Africa and Chile is in line with contemporary realists. Hayek thinks the state is the prime international actor and the balance of power between them a natural and positive phenomenon. He also thinks it very unlikely that a dominant power behaves idealistically in international affairs: 'how small is the likelihood it will be unselfish and how great are the temptations!'. Public opinion is no pacifying force either. It still does not qualify Hayek as a realist.

\section{Kantian tradition}

It is safe to conclude that Hayek's thoughts on international relations are hardly influenced by Kant. Although Hayek is famously on record with a plea for a liberal Utopia, this must be interpreted as a call for better 'marketing' of the liberal side in the battle of ideas. He certainly does not think that a perfect order is possible. His social evolutionism is stringently antiUtopian (Gissurarson, 1987: 13-14), he principally turns against this kind of thought, which he regards as a danger to classical liberal ideals (Kotterman-van de Vosse, 1994: 87-88). If they are shown wrong in practice, idealists are the first to turn to weapons and coerce people in what they perceive as their best interests (RS: 169).

The only article that can be regarded as straightforwardly Utopian is a long piece Hayek wrote [but apparently never published, $\mathrm{EvdH}$ ] as a very young man, most likely during his year-long stay in New York, in 1924. He argues that the First World War could possibly have been prevented, or at least have been restricted in the number of participating countries, if only the public would had been completely and impartially informed. To prevent such a war from happening again, he proposes that 'all countries bind themselves to require the daily newspapers within their territory to print regularly a page of news and articles compiled by an international committee', which should guarantee that all interests are given a due place on that page (Hayek, undated). There is no need to discuss the problems associated with this proposal. It suffices to stress that he quickly changed his mind (RS: 166; LLL, II: 134). He also opposes the optimism of David Mitrany, who predicted that planning would be out of fashion within a 
generation, because it comes at the cost of freedom of thought. Hayek thinks this is doubtful and points to the power of state propaganda as counter evidence. It is more likely that the struggle for the survival of ideas becomes a war of ideologies between nations, which may lead to the 'the destruction of everything which to us represents the greatness of humanity' (SW: 211).

Hayek is certainly no Kantian in his practical politics either. Besides his views on the state, war and the balance of power, he rejects most international organisations and considers a world state a major threat to individual liberty. He opposes his Chicago-colleague John Nef's call for 'more love' in world politics. 'Love is bound to the concrete and individual sphere and ought to be kept out of all these problems of international order'. Hayek aims for a spontaneous international order. The great fallacy is to think that a peaceful international order can be established by a concern for particular aims. Although people should generally aim at its establishment, the international rule of law will not be achieved by creating new international institutions. People do not know how to restrict organisations and therefore it is an illusion to think that more international organisations lead to peace (Hayek, 1968). With his respect for tradition and spontaneous evolution, Hayek clearly is not in favour of revolutionary designs for a better world.

The closest he approaches these ideas are in his support for federalism, but even then he always makes clear that the role of national states should be preserved. The Hayekian approval of some supranational institution building matches with his ideas on spontaneous order. 'The elements of the spontaneous macro order are the several economic arrangements of individuals, as well as [emphasis by Hayek] those of deliberate organisations'(Hayek, 1991: 37). There is no contradiction in this. Throughout his work he stresses that if a more efficient way of organisation develops, there is no classical liberal objection to it. Not even if it means allocating power beyond the national border. He may be seen as a universalist, because for him all human beings have the same rights and duties, and all are able to live in a liberal society. This hardly makes him a Kantian though. 


\section{Grotian tradition}

Like Hume, Smith and Mises, Hayek must be considered a Grotian, and his views on war, the balance of power and international development aid clearly mark him as pluralist within that tradition. The importance he attaches to the maintenance of international order exclude Hayek from the solidarists. 'As is true with other evils, the measures by which war might be made altogether impossible for the future may well be worse than war itself. If we can reduce the friction likely to lead to war, this is probably all we can reasonably hope for'(RS: 176). He realises the inevitability of war, but always tries to justify the reasons for warfare.

Besides his continued endorsement of international law (Curzon Price, 1996: 311-312), the best evidence for his Grotianism is contained in the following quote: 'neither an omnipotent super state, nor a loose association of 'free nations', but a community of nations of free men must be our goal' (RS: 175). Hayek's ideal is the Great Society [emphasis added, EvdH]. International society must grow spontaneously, it cannot be a constructed order. There should be no positivist international law, international order needs to grow piecemeal (Hayek, 1992: 260). This is not to say that Hayek studied the work of Grotius in detail, because without justification he writes two contradictory opinions about him, within a period of three years (compare LLL, I: 21; LLL, II: 53)

Hennecke is wide of the mark to exclusively relate Hayek's concern for the international rule of law to the influence of Kant. He seems to be unaware of the English School, because he notices that Hayek's international politics is neither dovish nor hawkish, neither realist or institutionalist, nor is he in favour of a world government (Hennecke, 2000: 342, 345). Ebenstein clearly exaggerates when claiming that Hayek's ultimate goal is the establishment of a universal order of peace (2001: 319-320). He sometimes hints at the idea, but his overall thought on international relations is different. Limiting states through international law to reach some international order is the highest achievable aim in international relations. This becomes even clearer when looking at a quote of Hayek provided by Ebenstein himself. In 1968, Hayek argues in favour of 
'international law, not international government, a system of rules which bind the individual states both in their relations to each other and in their relations to their citizens .... But you cannot have an international authority so long as individual states are free to do what they please. International order will therefore be achieved only by reducing powers of governments all around' (Ebenstein, 2001: 393, n.2).

Hayek is the fourth and last classical liberal analysed in this thesis. Like his peers he is a Grotian in his ideas on international relations. With Hume and Smith he clearly shares a pluralist leaning and with Mises the belief that only free trade promotes development.

Hence, a relation between the Grotian tradition in IR and the classical liberal tradition in political theory has been established, which is completely novel. In addition to the international politics elements identified at the end of chapter four (nation, balance of power, just war, free trade and anti-imperialism), the chapters on Mises and Hayek made clear that a modern classical liberal theory of IR must also include the 'hidden' costs of war, international federation and the rejection of development aid. In the next chapter, a further synthesis of these elements and a discussion of the implications for liberalism within IR-theory will be given. 


\section{7 \\ Liberalism and International Relations Theory}

The ideas on international relations of the four classical liberals have enough in common to enable the introduction of a comprehensive classical liberal theory of IR. However, it is only possible to present its contours, as almost any individual element of the theory needs a chapter or booklength treatment to do it full justice. This is beyond the scope and intention of the present chapter and of the thesis, but might well serve as a guide for future work. The same applies to some thought provoking pieces on international relations by libertarian authors, like Rothbard and Hoppe. A full treatment of libertarian IR would need substantial analysis, if only because there are many different libertarian views on international affairs (see Barnett, 2007).

The classical liberal theory of IR has two functions. First, it is meant to be an analytical device to help understand world politics. Second, it is normative. Given the analysis in the four preceding chapters it can be said that these classical liberals aim for a world that generally complies to the overall theoretical framework presented here.

The first part of the chapter introduces the main elements of the classical liberal IR theory. Where applicable, the viewpoints of current writers in the classical liberal tradition are included, although these writers were obviously not aware of this first comprehensive approach to classical liberalism and IR theory. Deviations between the theory and their views may therefore lead to a discussion within classical liberalism on issues of international relations. While these current authors may also regard themselves as classical liberals, in this chapter the general term classical liberal is 
used to describe the theory based on the ideas of Hume, Smith, Mises and Hayek.

As indicated in the introduction, despite some differences between the two realms, the international theory will be presented in the same way as domestic classical liberalism was introduced in chapter two. This allows for comparison and makes it easier to determine whether the IR theory is sufficiently rooted in classical liberalism. Also, the coherence of the classical liberal theory in comparison to the English School traditions will be made explicit. Where possible the elements of the theory will be discussed with references to other scholarly work, which makes the connection between the classical liberal IR theory and other IR theory more visible.

Throughout the thesis different kinds of liberalisms in current IR theory have been referred to. The differences between the classical liberal IR theory and these other liberalisms will be addressed in the second part of the chapter. This will lead to a call for a different, more comprehensive presentation of the liberal tradition in IR theory.

\section{The Classical Liberal Theory of International Relations}

One of the key aspects of classical liberalism is that it applies the same core principles to domestic and international politics. While acknowledging the differences between these two spheres of political action, the four classical liberals analysed in this book make it clear that their views on individualism and freedom, natural law, spontaneous order, limited government and the rule of law (all introduced in chapter two) are directly applicable to international relations. In both domestic and international politics, the ultimate goal of classical liberalism is to maximise individual freedom for all people in the world.

\section{Individual and Freedom}

\section{Human nature}

International relations are all about human action (Jackson, 2000: 31-38). The starting point for the classical liberal IR theory is therefore its view on 
human nature. All four classical liberals have a realistic view on human nature. Man is flexible and the use of reason allows him to choose and adapt to changing circumstances, but this rationalism is not dominant. Man is also 'a slave to his passions', often preferring short term minimal gains above long term real interests. Humans possess only imperfect knowledge and are driven by a well recognised self-interest. Man is also a social being, living in groups and forming societies. Societal order is possible, through the workings of spontaneous processes such as the development of morality, customs, traditions and the active maintenance of the rule of law. Conflict remains a fundamental part of the human condition. Not one of the four thinkers predicted that conflict, domestic or international, would disappear or gave this idea a central place in his writings. This is consistent with the realist and Grotian positions in the English School, but marks a fundamental difference with the Kantians, who have a positive view on human nature and believe it is possible to overcome international conflict.

In general, views of human nature are much discussed in academia, because they are of central importance to any vision on the future of humanity. In this context it is worth noting that there is growing, albeit not conclusive, evidence from the life sciences, in particular evolutionary psychologists and neuroscientists, for the classical liberal view of human nature, which in essence combines innate features and external socialisation. For example, contrary to the ideas of many social scientists, the mind and its innate reflexes and conditions direct individuals and their capabilities to a great extent, as a result of evolution and adaptation to specific circumstances (Tooby and Cosmides, 1992). Pinker adds that the mind is not a blank slate waiting to be filled by external ideas. This is an erroneous idea which had devastating effects. For example, it gave opportunity for all kinds of regimes to try to change the lives of humans through social engineering. He contends that the numerous attempts to get rid of human violence will inevitably remain without result. There is a strong and timeless relation between violence and the psychology of the idea of honour, which causes ongoing cycles of violence between gangs, militias, ethnic groups and states. Contrary to earlier romantic ideas there have never been peaceful primitive tribes either. Warfare is a natural condition, although there have always been attempts at conflict resolution and peaceful co-operation. 
Which of the two prevails depends on the particular circumstances of the situation (Pinker, 2002: 56-58, 428-431; also Van der Dennen, 1995).

Applying this to international relations, evolutionary theorists explain that war, power struggles, ethnic struggle and attempts to gain and defend resources have been proven strategies for survival and natural selection since the Stone Age, so it is not surprising this type of behaviour exists to this day. However, as indicated, war and conflict cannot be exclusively explained by bioscience. Human institutions are able to suppress conflict in some cases (Thayer, 2004: 263-270). Therefore, the behaviour of states depends both on the biological factors affecting agents and the strength of social institutions (Rosen, 2005: 2).

While unfamiliar with these modern insights, the classical liberals studied here, most likely on the basis of keen insight and sharp observation, have always realised that the relevant question in international affairs is not how to get rid of violence, but how to deal with and limit its inevitable occurrence. Their ultimate common goal is the expansion of individual freedom. International conflict easily exercises negative influence on this, which is one of the reason why they touch upon international issues so often. Individual freedom is severely restricted in a situation of war of conflict and questions of international order are directly related to domestic order, negative freedom and other conditions that need to be met before the individual can fully flourish.

\section{Nation and nationalism}

As discussed in chapter two, classical liberals feel man is unable to survive without social ties and the family is seen as the prime social unit. Hume, Smith, Mises and Hayek attach great importance to groups in general and they also point at the strong emotional bond between individual and their nation or state. In the words of Hume 'man, born in a family is compelled to maintain society, from necessity, from natural inclination and from habit '(E: 37). The bond with the nation is both natural and powerful according to all four classical liberals, which has direct relevance to the classical liberal view on international relations: the emotional tie with the nation introduces a natural divide between 'them' and 'us'. The work of Hume and Smith made clear that emotional ties between individual and nation 
existed long before the age of nationalism, which roughly started from the 1850s onwards. Therefore these feelings are 'pure' emotions, even though national conscience is partially formed under the influence of education and upbringing (Conway, 2004: 1-2) which makes many states 'imagined communities' or the products of an active 'construction' of national ties between the people in a certain territory (Anderson, 1996). This does not diminish their relevance in international relations, all four classical liberals think the sovereign state is the most important international actor. Again, this is consistent with the views of the Grotians and the realists, but differs from Kantian ideas on world federation or other forms of global human unity and union.

As long as positive national feelings remain limited to a form of patriotism no harm is done, as Hayek pointed out (see previous chapter) and as Hume and Smith alluded to in their writings. However, Hayek and Mises experienced that it is troublesome when patriotism degenerates into nationalism, which is essentially a collectivist and in many instances a violent theory that poses a serious threat to individual freedom. Liberalism and nationalism are antidotes but have become allied in the nineteenth century (Robbins, 1971: 263-267), in particular under the influence of John Stuart Mill. Hence, Hume and Smith were not aware of it, but given the clear contradiction between collectivist nationalism and classical liberalism, anti-nationalism may safely be assumed a part of classical liberal IR theory.

From this perspective it is problematic that a current writer in the classical liberal tradition overlooks the dark sides of nationalism in his defence of a liberal nationalism, which exclusively relies on its benign, patriotic features (Conway, 2004: 81-86).

\section{Empire}

According to Mises and Hayek, one of the worst features of nationalism is its strong relation with imperialism. If one holds one's country superior to others, it is indeed a small step to go out and attempt to improve the world, to rule 'the inferior barbarians'. This is encouraged by perceptions, as those of John Stuart Mill, that imperialism also offers geopolitical gains and chances for economic exploitation (Jahn, 2006a: 191-201). For Hayek 
this was another major reason to criticise Mill. Anti-imperialism has been a prominent feature of classical liberal international relations, from the support for American independence by the Scots, to the support for decolonisation by the Austrians. All four classical liberals oppose imperialism and favour decolonisation, which are seen as serious infringements of individual liberty. They have this in common with the Kantians and the Grotians, while they differ from the realists who have no great difficulties with territorial expansion or military conquests (Wight, 1991: 275).

The classical liberal position towards the related issues of sovereignty and the right to self-determination starts with the assertion that there is no need for every nation to be organised as a separate state. Like Acton wrote, it is perfectly feasible for two or more nations to live within one state. Yet, as Mises points out, there is also an individual right of self-determination, which grants every individual the right to live where he or she wants. This is however limited by the negative rights of the people who may already inhabit the chosen location and also those of the people who are to be left behind. Possible conflicts are less likely to occur in a situation where the state has a limited number of tasks and capitalism prevails (Ebeling, 1995: 59-62), which limits the number of 'public entitlements'. None of the other classical liberals wrote about this in detail, but as it obviously complies with the elements of individual freedom, the right to property and calls for a limited state and is therefore added to the classical liberal IR theory.

Given decolonisation in Latin America the 1830s and in Africa and Asia after the Second World War, it seems that questions of empire are historically dated, or at most reduced to the questions about the status of mostly small islands that still belong to former colonial powers. Therefore, it is surprising to find that among current American writers in the classical liberal tradition there is a continued concern for the 'American Empire' and its expansion (Ebeling and Hornberger, 1996; Eland, 2004). They argue that the alleged desire to keep an empire is the major cause of all the faults of US foreign policy. Compared to Hume, Smith, Hayek and Mises these writers define empire far more broadly, often using the number of US military bases overseas and American foreign interventions as a yard stick. This alleged empire is seen as contrary to the intentions of the Founding Fathers and undermines the credibility of American cries for democracy elsewhere, especially when the US keeps dictators in power. It leads to forms of anti- 
Americanism (Carpenter, 2002) and even to terrorists acts against America (Eland, 2002; Ebeling and Hornberger, 2003; Higgs, 2005).

From a broader IR perspective, this seems to be a rather specific interpretation of empire. It also assumes that all US action abroad is against the will of the people concerned, without mutual benefit and by definition against the general American interest. Mainstream IR accounts are largely dismissed. Hence, there is no room for the idea that the American-centred post-war order is actually characterised by an absence of coercion, that the US does not seek to infringe on the sovereignty of other states, nor wants to control the sovereignty of other nations (Jackson, 2007a: 309). It is also denies that reciprocity, cooperation and a diffusion of power allow American allies as the Europeans and the Japanese to participate in the policy making for the overall system (Ikenberry, 2006: 94).

The concern for empire sometimes appears to turn into a plea for strict non-interventionism or isolationism. Therefore it is striking that Lal (2004) actually defends empires from a classical liberal perspective, arguing that they promote peace and prosperity. Discussion of these positions goes beyond the purpose here. Suffice it to note that there is a lot of opportunity for debate among classical liberals. This debate benefits from taking into account a wider angle than just US foreign policy. A minimum requirement is the inclusion of the insights of IR-theorists and the comprehensive classical liberal IR theory of international relations introduced here.

To sum up, the concern for the individual and freedom in domestic classical liberalism also found its way into classical liberal IR. The realistic view of human nature leads to two crucial positions. First, that conflict in innate to humans and second that there is a natural division between sovereign nations in the world. Combining these two views with the concern for individual freedom leads to strictly anti-nationalist and anti-imperial positions, which is most consistent with the Grotian tradition in English School theory.

\section{Natural law and natural rights}

\section{Classical human rights}

The classical individual rights are an integral part of classical liberal theory, 
both domestically and internationally. None of the four classical liberals limit their application to the national border. Hume is largely silent on the subject except in the discussion on American independence, but - allowing for the different contexts - Smith, Hayek and Mises argue in favour of the universal application of the basic human freedoms. The state is seen as the main defender of this rights, in the international realm for example in the form of international treaties. As discussed below, Mises and Hayek strongly reject the defence of social and economic rights, both domestically and in international organisations like the UN. These intrude upon individual negative liberty and allow the state to unduly expand. This is what Hayek called 'social constructivism' and is very much like Smith's warning against the 'man of system' in politics. Therefore, only the defence of classical human rights can be counted among the elements of the classical liberal IR theory, which is consistent with the Grotian position. Realism considers the national interest of greater importance, while the Kantians explicitly argue for the application of broader definitions of human rights.

\section{Just War}

War, or the deliberate, controlled and purposeful use of violence to attain political objectives (Howard, 1992: 24-25), either by or between states or non-state groups, is one the most important institutions of international society. Following their view on human nature, classical liberals think the occurrence of violent conflict and war is inevitable. Neither Hume, Smith, Mises or Hayek foresees perpetual peace and they all support warfare in specific circumstances. They think this warfare must be limited to just causes. States have the moral duty to refrain from unjust war. The concern for just war, with its basis in natural law, is a strong and direct links between domestic and international classical liberalism. The shared natural law origins of both classical liberalism and Grotianism is also important for explaining other similarities, for example the idea that individuals rather than states are bearers of rights and duties (Bull, 1995a: 27-28).

The just war tradition after which classical liberals aspire, goes back at least to St Augustine, St Thomas Aquinas and the natural lawyers. Grotius is perhaps the most well known representative. Thinking in terms of just war is normally divided in two categories: just causes of war (ad bellum) 
and just conduct in war (in bello). Grotius saw four just causes of war: self-defence, the right to inflict punishment on enemies for breaches of the laws, the recovery of property rights and the recovery of debts arising from contract. Sometimes these latter two were combined (Jeffery, 2006: 2749). Related demands, resulting from the further development of just war thinking, are the need to declare war by a legitimate authority, the need to have a right intention for war, the probability that war must do more good than harm and the requirement that war is a last resort after careful deliberation on other courses of action. Important rules are also that force may only be used proportionately and that war parties are obliged to make a distinction between combatants and civilians, who may never be the intended target of war action (Elshtain, 1992b: xiv-xv; Clark, 1988: 31-50). These latter elements also comply with the classical liberal defence of personal liberty.

Needless to say, the just war tradition is characterised by continuous debate, for instance on the nature and meaning of the demands summed up above, alternative requirements, the usefulness of the idea itself and not least the application of just war theory to practical situations. In past decades this has been stimulated by the publication of Michael Walzer's Just and Unjust Wars (1992) and practical developments in world politics like the fight against terrorism (see for example Walzer, 2005; Armstrong and Farrell, 2005; Rengger, 2002; Elshtain, 2003; Reed and Ryall, 2007). The just war tradition tries to limit the circumstances when and how force may be used. At the same time, it is realised that certain circumstances demand political leaders to resort to war. This way of thinking differs from realism in that it seeks to enforce ethical norms for the use of violence, and from pacifists in its realisation that both peace and the status quo can maintain severe injustice. Justice may sometimes be served by the just use of force. Just war theorists emphasise that there is no simple solution to debates on international violence. 'Although never regarding war as desirable, or as a kind of social "good", the just war tradition acknowledges that it may be better than the alternative' (Elshtain, 2003: 56-57). The four classical liberals did not discuss their views in so much detail, yet they all indicated concerns and opinions clearly along these lines, with Hume and Hayek applying the just war criteria to topical international issues, such as the 1771 Falklands War and the Iran hostage affair respectively. 
From Hume onwards, classical liberals show concern about the impact of war on the general level of freedom in society and therefore they never regarded as a regular policy instrument. The idea that a war economy needs government planning and control is strongly rejected by Mises and Hayek, while the negative effects of other controls, like propaganda and restrictions on free speech are also elaborated upon. This is also a concern for Hume and Smith, especially the costs of war, so it will be included in the classical liberal IR theory.

Among the present scholars who label themselves classical liberal Higgs has specialised in the topic of the costs of war. He makes it very clear that there are always economic costs involved in warfare, there is no such thing as 'war prosperity' (Higgs, 2004: 219-226). Governments use the public demand for their services in times of crisis and never fully restore the pre-crisis situation. In the process they expand their powers and state influence over individuals. In this sense, war is the ultimate crisis (Higgs, 2006), and the current war against terrorism is no exception. Since 2001, there have been an enormous expansion of government expenditure and a severe limitation of civil liberties, especially in the US (Higgs, 2005; Ebeling and Hornberger, 2003).

The four classical liberals acknowledge this general line of thought, but are less persuaded than Higgs that it is possible, or even preferable, to refrain from this type of public spending. They regard external defence as one of the prime tasks of the state. War and war preparation are not only inevitable, they are justified because they contribute to the preservation of individual freedom.

In sum, the classical liberal elements of natural rights and natural law find their expression in the classical liberal IR theory through support for the defence of classical human rights, the importance attached to just war and the recognition that war has a lot of hidden costs that infringe upon natural rights, especially those to liberty and property. This is a clear Grotian position, compared to the realist and Kantian ideas on these issues, as discussed above and also in chapter one. 


\section{The state}

Despite the danger states pose to individual liberty, a world without states is unthinkable for the classical liberals. They argue that the state is needed to defend individual liberty, but realise that is also the greatest threat to it at the same time. As discussed above, the sovereign state is the prime international actor according to Hume, Smith, Mises and Hayek. They recognise individual and non-governmental action at the international level, but do not consistently argue in favour, or show a belief in, a world without states. States need to deal with each other and the Scots and the Austrians think about the inter-state world in terms of an international society, as defined in the introduction. Inter-state cooperation is more than a power game with its origins in a perpetual dilemma of state survival, while a world without states, or one world state is rejected as well, both on practical and principal grounds, to be discussed below.

For Jackson international society is 'the historical expression of classical liberalism', because it provides people with the ability to live together in their own independent state, according to their own conventions, ideas and morals, governed by their own leaders (Jackson, 2000: vii). This assessment largely complies with the views of Hume, Smith, Mises and Hayek. In the English School, both the Grotian and realist tradition see the state as the most important actor, while the Kantians aim to get beyond state domination in world politics.

\section{State and federation}

A society of states is the preferred classical liberal mode of international organisation. However, Hume in the essay Idea Of A Perfect Commonwealth (E: 512-529) and Smith in The Wealth of Nations (WN: 529-539) endorse (transnational) federations and Mises and Hayek fully elaborate on the special situations when other forms of organisation are preferable, most notably interstate federation. This is the case when the formation of a regular society of states is not feasible due to (violent) issues of nationality, religion or ideology. For both Mises and Hayek this applied to Western Europe in the nineteen thirties, Eastern Europe after the Second World War, and for Hayek also in the Middle East, in particular Jerusalem. Accordingly, 
the idea of transnational federation is part of classical liberal IR theory. Theoretically, a world federation may be a possibility, but stays out of the theory on consequential grounds; the four classical liberals fear states that obviously endanger individual liberty and in a one state world this would be real possibility. As Hayek pointed out, humans have not even learned to effectively control the state powers in a national setting. A confederation of national states, or Staatenbund, has never been very successful, because states keep their sovereignty and decrees against them can ultimately only be enforced by armed action. As a middle way, federalisation is the ultimum remedium, a solution in very special circumstances.

The appeal of the federal idea is that it starts with a shared agreement on its underlying objectives and ideals, which means it most likely preserves the unique characteristics of the constituent nations. As long as its politics are mostly decentralised and supranational unification is strictly limited to a small number of tasks, the chances that it develops into a dangerous super state are small (Robbins, 1971: 267-272; Robbins, 1937: 242-268). If established in this way it complies to the classical liberal element of the limited state. The English School is mostly silent on this issue, but federation is compatible with all three traditions: the realists and the Grotians put emphasis an the overall world of states that remains even when a number of states merge into a federation, while the Kantians regard it as a first step towards world federation. As indicated in the introduction, the English School is also silent on the issue of European integration and the classical liberal approach introduced below may contribute to more reflection on this issue.

\section{European integration}

Smith spoke of Europe in terms of a cultural unit and Mises and Hayek actively endorsed attempts to form a European federation which strictly complies to the classical liberal elements of a limited state, rule of law and individual freedom. They did not see this European federation as a threat but as a safeguard for its constituent nations.

For Mises and Hayek a regular division in states is not feasible in Europe, they favoured the formation of a small European federation with limited tasks, foreign policy and defence included (also Röpke, 1959: 43- 
56), as long as a number of conditions are met. Politicians are not allowed to create a federation with too much central power. From a classical liberal view it is essential that the integration proceeds with full consent of the (large majority of) people involved and that the federation has a minimal number of tasks. The latter requirement reduces the chance that there will be a perpetual struggle for a large share of central power among representatives of the constituent nations. The maximisation of freedom of European individuals must be the main goal of any European federation.

Given the importance of the current European Union in world politics it will be briefly assessed, which also serves to illustrate the possibilities for the practical application of the classical liberal IR theory.

Before the EU can be turned into a federation major changes need to be made, because it does not resemble the classical liberal view in its current form. The EU actually confirms Mises' and Hayek's early assessment that the European leaders set out to create a super-state, which has developed into major threat to individual liberty in Europe. The European integration process is a prime example of political constructivism. The continued expansion of tasks and regulations at the European level are much harder to reverse than in domestic politics. In this sense the Austrians were right again: the EU is both an example of Mises's argument that 'a middleof-the-road-policy leads to socialism' and Hayek's 'road to serfdom'.

People are trapped in a half-liberal construction, which makes it hard to predict the ultimate failure of the EU. If the EU continues to grow without public support, classical liberals foresee its end. The Humean insight that all political systems rest on public opinion remains valid in this respect. The rejection of the draft Constitutional Treaty by French and Dutch voters in June 2005 may serve as an indication.

A constructivist basis and 'federal overreach' in terms of policies and power explains for classical liberals why the EU remains politically weak compared to the more solid foundations of most member states. In this context it is not surprising that the weakest European states are constructed nation-states (see the definition in the introduction), such as Belgium or, most obviously, former Yugoslavia and earlier the Austro-Hungarian empire.

Classical liberals propose big changes before the EU can be approved of. When Mises' and Hayek's ideas on 'domestic' and federal state tasks 
are applied, most of the current policies of the EU must be abolished. Obvious examples are the European policies in the fields of social welfare, healthcare, agriculture, science, education, regional policies, innovation, development aid and most of the other policy areas designated for closer co-operation in the redesigned en renamed, but almost unaltered former European Constitutional Treaty now known as the Lisbon Treaty. A classical liberal EU entails discarding tasks that currently take up about 80 to $90 \%$ of the EU budget.

Only a limited number of tasks can remain at the European level. The main ones are the basic mechanisms of the internal market, although there is a need for close scrutiny of many related laws and regulations. Both Hayek and Mises would prefer a Euro on the gold standard. In principal there is classical liberal support a further development of EU foreign policy and the attempts to develop a European common defence mechanism. A small number of policies for obvious cross border issues can be supported, for example in field of the environment. Federation is a means to keep the member states vital, it is no political end in itself. Any transfer of power to the transnational level must be limited and conditional, and can only be approved when individual liberty is safeguarded.

The classical liberals think that the EU is unique. In their writings there are no serious indications they think this process can be reproduced in other parts of the world. In principle, there is no objection to new federations, as long as they rest on popular support. For classical liberals, the pooling of a number of states essentially leads to a decrease of the number of participants in international society, but it does not fundamental challenge its existence. Cultural and national differences will prevent the development of a world state.

The European integration process has been successful in the prevention of war at the European continent, which may appear to be proof that increased trade and economic integration lead to peace. This would be an overvaluation of the economic component in European integration though. The EU started as a political project and has always remained one. There are many possible reasons for the European peace since 1945. Three Franco-German wars in seventy years, had increasing effects on the whole world. The devastation of the Second World War made many of the post war leaders determined to prevent another European war at all means. 
The European regional balance of power lost its prominence to the global one between the US and the Soviet Union and the ensuing Cold War also forced the Europeans to cooperate. This was also stimulated by the US, through diplomacy and the Marshall plan. Economic integration was a vehicle for European reconciliation, but even the European Coal and Steel Community cannot claim credit for the prevention of war in Europe. The (hampered) trade in those products did play a role in the outbreak of the three previous wars, but the coal and steel sectors were not no longer of the same strategic importance after 1945. Instead, NATO was most important for European peace, as it bound Western Europe and the US, not least in the way of nuclear armament and the Cold War doctrine of mutually assured destruction (Gillingham, 2003: 22-23). Increased trade ties were beneficial for the member states, but only power politics held the peace in Europe. The history of EU integration delivers more evidence for the idea that there is no relation between trade and peace, than the reverse idea.

\section{Diplomacy}

In the international society of states, official day-to-day relations between states are conducted by diplomats. Part of their job is to reduce the ever existent frictions between the actors in international society, and as such, diplomacy is an expression of the existence of international society itself (Bull, 1995a: 156-177). It is no wonder that all four classical liberals, with Hume and Smith as the most explicit defenders, value the influence of personal conduct, or agency, in world politics. In contrast to the realists, they do not argue that structures determine the outcomes in world politics. Diplomacy, or the 'people-side' of international relations, is at least of similar value. They would agree with Hill, who argues that diplomacy remains an inherent part of all international action, from serious crisis to routine dayto-day politics. Diplomacy is a crucial instrument for international stability, it is 'the human face of getting your own way in international politics'. In his view diplomats perform four tasks: communication, negotiation, participation in multilateral institutions and the promotion of economic goods (Hill, 2003: 138-143). Classical liberals are not in favour of this latter task, which easily leads to mercantilism and economic nationalism. Yet diplomacy is an important institution in classical liberal international 
relations, fully in line with the Grotian position that diplomacy is mostly about uniting the members of international society. The Kantians see diplomats as part of the war mongering classes, whose secretive dealing present a danger to world peace (Wight, 1991: 180-205).

To summarise, classical liberals positively value the role of the state in international relations. The state is the prime actor in world politics, and external defence against intrusions of individual liberty is among its principal tasks. States communicate and negotiate through diplomacy, which helps to reduce conflict. State tasks must be limited in number, which is also consistent with classical liberal demands to the state in a domestic context. Only if a society of states is impossible, hence when international anarchy poses a big threat to international order and individual freedom, international federation is a preferred alternative. Again, just as long as the central governing unit only has a limited number of tasks and power and does not aim to become a world government.

\section{Rule of law}

International law is the body of rules which binds states and other agents in world politics in their relations with one another (Bull, 1995a: 122). As such it is the expression of the common norms and goals of international society. From a classical liberal perspective it serves as the rule of law at the international level. Hume and Smith embrace the rudimentary 'laws of nations', which in their days was a rather limited set of rules, mainly consisting of the regulation of diplomatic practices and rules for warfare. Mises and Hayek also emphasise the importance of international laws, especially for dispute settlement. All four recognise that in a world of states there is no ultimate arbiter. In the words of Bull, without a central enforcing authority, international law is in principal enforced by the member states themselves, in the form of sanctions or ultimately war. While sometimes a particular rule is broken or interpreted in a one-sided way which might lead to conflict, states usually judge it in their best interests to conform to international law. International law is the content of the rules of coexistence among the states and other actors, and it also helps to mobilise compliance to these rules (Bull, 1995a: 125-134). Good international law 
for classical liberals ensures the smooth functioning of international society, which may be helped by an international court, and contains a limited number of general rules to help solve international issues, for example the law of the seas.

Like law in domestic politics, international law must be restricted to the protection of the natural rights of the individual. It is therefore not surprising that Mises and Hayek object the explosion of positive international law since the late nineteenth century and the subsequent establishment of many international governmental organisations. With their preference for a limited state and protection of negative individual liberty they fully stand in the classical liberal line of thought of Hume and Smith in this respect. Therefore the limitation of international law is considered part of the classical liberal IR theory, which is in line with Grotian thought and opposed to the positivism of both realism and Kantianism (Wight, 1991: 233-258).

Outside the direct concerns of the English School, classical liberals see the many international institutions, often created by governments of nonliberal persuasion (Röpke, 1959: 12-20), as attempts at Hayekian social constructivism at the international level. Mises and Hayek were among the first to warn against the extended number of tasks of the League of Nations and both rejected the set up of the United Nations. Hayek in particular warned against inclusion of social and economic rights in the Universal Declaration on Human Rights and was very critical of the International Labour Office. For classical liberals there is as much danger in an abundance of rules and state organisation at the international level as there is nationally.

Consequently, classical liberals favour the abolition of international governmental organisations with tasks that extend beyond the principles of the limited state, spontaneous order (discussed below) and the protection of individual natural rights. Without being able to go into much detail, and taking into account that it is a thin line between common sense international cooperation between states and the need for international bureaucracies, a rule of thumb is: if there is no need for state interference in a domestic situation, there is no need for international state action either, with the exception of some tasks that follow from specific international circumstances. 


\section{Spontaneous Order}

Classical liberals reject governmental constructivism and instead heavily rely on processes of spontaneous order, which -again- call for limited state action. Hume, Smith, Mises and Hayek also apply this classical liberal element to international affairs.

\section{Balance of power}

All four classical liberal thinkers acknowledge that there is not an ultimate power in the international society of states, but none of them endorses the creation of one in the form of a world government. Hume, Smith and Hayek (Mises is mostly silent on this issue) see the balance of power as an important mechanism to keep international order. The balance of power has all the characteristics of spontaneous order (see chapter two) applied to the international arena. It is beyond the control of any individuals state; it is the result of human action but not of human design; it is never stable; and is the result of competition between states. The balance often assures smaller states the power of independent action, by enabling them to choose between alliances. The relative power positions of states, in military, economic and cultural terms, are important inputs to the overall balance at any moment in time. Classical liberals feel there is often more danger to individual freedom in a world dominated by a single power than in a pluralist world. Hence, the appreciation of the balance of power which aims to prevent such a domination. In modern terms: 'beliefs about the dynamics of power balancing and the effects of polarity on system stability play a central role in the formulation of grand strategy'(Ikenberry and Kupchan, 2004: 38).

It must be acknowledged that the balance is not a perfect safeguard of everybody's natural rights. Balance of power politics sometimes make victims in international relations, for example through war. That is one of the reasons classical liberals do not rely entirely on the balance to keep international order. The other institutions of international society, for example international law, are also important. In general, the balance of power has a tendency to work to preserve the status quo by putting brakes on territorial changes (Butterfield, 1966: 142-144), and for many countries the balance 
of power simply means survival. It has prevented many wars and the alternatives are 'either universal anarchy, or universal dominion' (Wight, 1995: 175-177, 184-185). Hume (E: 337) famously said the balance is 'founded so much on common sense and obvious reasoning'. The classical liberals have this in common with both realists and Grotians, while it is another point of division with the Kantians.

Not all modern authors in the classical liberal tradition share this appreciative stance of the balance of power, certainly not in the context of discussions on US foreign policy. For example, Higgs argues that the prime and only objective of US defence should be the protection of US citizens and their property within their territory from attack by hostile states. All balance-of-power-politics must be eschewed (Higgs, 2004: 250-251; also see Paul, 2007: 2, 8). Galen Carpenter argues that the US should indeed withdraw from alliances such as NATO and the defence treaties with Japan and South Korea. Instead, America should become the 'balancer of last resort in the international system', which means that it retains enough military force to stop 'unusually potent, expansionist threats' to international stability that cannot be contained by alliances of other, smaller powers (Carpenter, 1998). These writers almost exclusively emphasise the possible negative effects of the balance of power and do this exclusively from an American point of view.

\section{Trade and peace}

One of the characteristic features of classical liberalism in domestic and international politics is its emphasis on the positive role of capitalism and free trade. Hume, Smith, Mises and Hayek are principled free traders. Indeed, in many cases their free trade position is one of the few positions they are associated within IR. This belief relies on the belief in spontaneous order, individual natural rights and the limited state. For classical liberals trade should largely be free from governmental interference, as state meddling is considered mercantilist. To trade and engage in other economic activity is an essential part of individual freedom (Friedman, 2002: 7-21).

Despite the assertion that the Grotians see trade as the particular activity that typifies international society best, 'or more generally economic and social intercourse between one country and another' (Bull, 1995a: 25), the 
economic element is almost lacking in traditional English School thought. In this case the added value of the classical liberal position is clear.

All four classical liberals argue against trade distorting measures, such as tariffs and non-tariff barriers of trade (see Trebilcock and Howse, 2005) and favour unilateral trade liberalisation in the belief this will bring most benefits to most people, for Mises and Hayek also in developing countries (also see Lal, 2006).

Hayek is positive about the progress in GATT, but emphasises that government intervention in trade seldom has benefits. This is also in line with the ideas of the other three thinkers. Combining this position and the negative classical liberal attitude towards international bureaucracies it is likely that in their ideal world there would not be a place for an international governmental trade organisation, such as the current World Trade Organisation (WTO). After all, in the WTO states bargain over issues which should be out of their control in the classical liberal view. Paradoxically, the WTO is often a barrier towards free trade, because it facilitates economic mercantilism and has fallen victim to interest groups politics, legalism and unnecessary harmonisation of all kinds of standards (Sally, 2003). This would probably not have been a surprise to the four classical liberals.

The question about the alleged peaceful effects of trade separates Smith and Hume from Mises and, to a lesser extent, Hayek. All four are positive about trade from welfare and cultural viewpoints. However, Hume and Smith never predict a positive relation between trade and peace, while most other liberals from the nineteenth century onwards do (Howard, 2004: 13-51), including Mises and - less clearly - Hayek. Under the major influence of Cobden and the Manchester School the liberals think that trade either directly or indirectly promotes peace. Given the counter evidence, elaborated upon below, is seems that the older classical liberals have the better part of the argument, which will therefore be included in the classical liberal IR theory.

Hume and Smith note that trade gives rise to all kinds of quarrels and jealousies. In the chapters analysing their ideas on international relations it became clear they underline that closer ties between nations also foster disagreement. Commerce cannot change human nature, it is unable to overcome such inherently human feelings as pride and jealousy which 
are the sources of much uncivil and belligerent behaviour. Even in a world dominated by commerce there cannot be lasting peace, because conflict is part of the human condition. Therefore, their writings do not provide evidence in support of the 19th century ideas that increased influence of public opinion in foreign policy guarantees peace, or middle classes opposition to war to protect commercial interests. Trade thrives in an atmosphere of peace, but does not create it (Röpke, 1959: 20), the Scots feel. Only wise policies and sometimes force can promote order (also see Margerum Harlen, 1999; Sally, 1998: 57; Irwin, 1996: 76; Whelan, 2004: 231; Manzer, 1996).

Here the Scots have a more consistent classical liberal position than Mises and Hayek, because their views on conflict and human nature are consistent. Only if trade leads to a change in human nature can it promote peace. The classical liberal view on human nature does not allow for such idealistic possibilities, which are associated with social liberalism (as discussed in chapter two). In this context it is perhaps also instrumental to reiterate the classical liberal view on trade. Trade is a process of buying and selling goods or services, between two or more individuals, who represent themselves or a (corporate) organisation. Both parties gain from the transaction, otherwise it would not take place, or it would not be a free transaction. In principle, borders are not important for this process.

While the trade transaction itself is inherently peaceful, it does not eliminate the causes of war. Trade makes nations richer and as Hume noted, increased welfare can easily be used for bellicose purposes. Groups in society can gain economically from war in the short to middle term, which may be tempting enough for some rulers. Also, trade does not erase other sources for conflict, for example those of a geopolitical or religious nature. Trade is seen to promote the international division of labour, which also increases the number of possible trading partners. This makes it easier and less costly to change one trading partner for another, so trade reduces the costs of engaging in warfare. Instead of preventing international conflict, economic interdependence also often leads to violent conflict. Economically strong states fighting more wars. The argument that trade leads to peace is therefore a 'liberal illusion' (Barbieri, 2005: 121-137), of a largely Kantian streak in terms of the English School. Realists and Grotians never predict or aim at the abolition of war from international relations. 


\section{Development aid}

The position on international development is the last defining characteristic of the classical liberal IR theory. It also concerns the application of spontaneous order and limited state action to international relations. English School theorists have not often discuss the pros and cons of development aid in detail, but the question is of specific relevance to the pluralist-solidarist divide (introduced in chapter one). Pluralists, together with realists do not see a moral obligation, nor much value in the provision of development aid, while solidarists and Kantians take the opposite position, arguing it is part of being 'a good international citizen' (Linklater and Suganami, 2006: 223-258). The discussion that follows makes clear that classical liberals belong to the first group.

Hume, both the Austrians and particularly Smith, observed that at the individual level the intensity of emotional bonds between people gradually decrease as group size increases. Beyond the level of the nation, people might have short term sympathy for the misery of other people, but these feelings cannot be said to ultimately direct human action.

Hayek and Mises argue against development aid, which particularly rests on the classical liberal rejection of government interference and arguments in favour of spontaneous order. They criticise it from its start in the late 1940s. A particularly strong influence on their and other classical liberal thought about development issues has been Peter Bauer, one of the pioneers in the field of development economics (see for example Bauer and Yamey, 1957). Bauer argues against the dominant idea that rich countries cause poverty in underdeveloped states or the existence of a 'vicious circle of poverty' from which no escape is possible. In line with Hayek and Mises he poses that central planning nor foreign aid are prerequisites for development (Bauer, 1971: 17, 31-146).

Consequently, the classical liberal position towards foreign aid is that there is 'no use in money transfers from the poor in the rich countries, to the rich in the poor countries', as Bauer famously stated (Blundell, 2002: 27-29). A main objection against aid for states is that it goes to governments who are then able to continue policies which may be counter-productive to the interests of their people. Examples are warfare or other policies that create refugee flows; the restriction of capital inflow and foreign private investment; suppression of private trade; expulsion of (productive) 
ethnic groups; repression of women; confiscation of property; forced collectivisation; all kinds of economic intervention; et cetera.

In the classical liberal view, put forward by Hayek and Mises amongst others, there are three persistent yet erroneous assumptions about aid: it promotes development; it alleviates poverty; there are important political and economic interests at stake for the donor countries. Instead they argue economic development mostly depends on internal factors. Capital accumulation is the result of economic development, not its precondition and it certainly does not depend on aid. Evidence shows that even poor people are able to save for investment. Aid often creates political gridlock, as it enables ruling regimes to stay in control through patronage, money transfers and other means of power projection. Governments most often sanction money transfers to private projects, so this is not a better way of giving aid. Also, aid enforces the idea that economic development depends on circumstances beyond one's control (see Bauer, 1991: 38-55; Lal, 2002). Hayek and Mises emphasise that societies that restrict capitalism are depriving themselves of the fruits of the information-processing capacity of the market order, and therefore 'succeed mainly in impoverishing themselves' (Curzon Price, 1996: 304).

The only solution, according to the classical liberals, is the restoration of free trade (both in the developed and underdeveloped countries), combined with free market economic policies and the implementation of social and political individual freedom (also Sen, 1999). Of course, there is no objection to philanthropy or non-governmental engagement with developing countries (see Lomasky, 2007: 221-222), for example in the areas of health and education. Classical liberals remain critical towards all attempts to develop countries from the outside, so decisions to spend on these kinds of activities should be made by individuals, not by governments with a power to tax. There is no foreseeable role for international governmental organisations, like the IMF or World Bank. Classical liberals are convinced that unhampered capitalism is the ultimate form of human co-operation, both nationally and internationally. It provides the only answer to questions about sustainable development and global poverty. 


\section{Main character}

The conclusion of this part of the chapter is that the application of the methodology introduced in chapter one confirms the existence of a classical liberal theory of international relations. The analysis of the international thought of Hume, Smith, Mises and Hayek shows that they apply their core ideas both to domestic and international politics, with the same aim:. to maximise individual freedom.

The analysis in the previous four chapters shows that Hume, Smith, Mises and Hayek are pluralist Grotians from an English School perspective. This chapter made clear this is also the right characterisation of the comprehensive classical liberal theory of IR. It is a coherently Grotian theory, which was also clarified by the comparison with realism and Kantianism. This is an important point, because most IR scholars see liberalism as a strand of Kantian thought, as will be shown below.

There is no indication that Mises or Hayek was aware of the existence of the Grotian tradition or the English School, which originated in the 1950s. Hedley Bull for his part did not write about the classical liberals, nor did he explicitly address the classical liberal tradition. Therefore it is notable that both Bull, in his classical Grotian English School text The Anarchical Society, and the four classical liberals distinguish the importance of the same institutions for international order: diplomacy, balance of power, war and international law. The only deviation is Bull's fifth institution, great power management, as far as this means that there is no or only a very limited role for small states in international relations. All four classical liberals explicitly defend the position of smaller countries as full members of an international society. Another similarity are the natural origins. While a direct line from Grotius to the Scottish Enlightenment has been detected before, this link has hardly been elaborated upon in an IR-context (Jeffery, 2006: 67).

At this point of the analysis it is clear that there are strong relations between classical liberalism, the Scottish Enlightenment, the natural law tradition and the pluralist Grotian position within the English School. Buzan's (2005) complaint about the lack of English School engagement in political economy and globalisation can be addressed by classical liberalism, although contrary to his expectations this does not strengthen the solidarist 
and world society perspectives. Classical liberalism also challenges the English School to further theorise about the European integration, issues like development aid and the historic roots of the Grotian tradition.

Classical liberals refrain from Utopianism and reject all other forms of determinism in IR. They focus on real world problems and do not have the rationalistic inclination, or the hubris, to think that they can 'help' (Rengger, 2000b: 769-770). The world may be improved, but only by piecemeal changes and reliance on spontaneous order. The classical liberal IR theory is therefore an expression of what Rengger (2006: 39, 45-49) terms 'Anti-Pelagian' theory. Hence it doubts the possibility to achieve Heaven on Earth. The elements of the theory provide a solid basis for further analysis into ways to achieve an international order which protects the classical liberal aims.

The theory does not address all questions raised in IR. An important oversight is the question about the justification of humanitarian intervention, especially related to concerns for classical human rights and the need for just war. This is an issue none of the four thinkers addressed, even though prominent liberal thinkers, especially Cobden, put much emphasis on the importance of non-interventionism. Also, there is no shared position on free immigration. The right to free immigration can easily be argued from an individual liberty perspective, but the need for controlled immigration as well, especially in a world with social welfare entitlements and modern transport which allows for great influxes of immigrants, which can easily upset an existing social order. A classical liberal position on these issues is needed, but must be part of the suggestions for future work.

With the main building blocks of the theory in place, the question that needs to be addressed is: how special and different is classical liberalism in a liberal IR theory context?

\section{Liberalism in IR Theory}

Liberalism, in its many different forms, has been among the most dominant theories since the start of IR as an academic discipline (Smith, 2007: 4). The major contestant in IR theory is realism. As elaborated on in more detail in chapter one, this is 'the tradition of political analysis that stresses 
the imperatives states face to pursue power politics of national interest' in international politics. It puts emphasise on reasons of state and the importance of the anarchic structure of the international system (Donnelly, 2005: 29-30). Liberalism in IR is mostly presented as the opposite of realism.

In an influential analysis, Zacher and Matthew describe it as progressive, co-operative and modernist. Progressive, because liberals believe that when their ideas reign free, international relations gradually transform to promote greater human freedom by establishing conditions of peace, prosperity and justice. Quoting Howard, Zacher and Matthew underline that 'liberals have faith in the power of human reason and human action so to change the world that the inner potential of all human beings can be more fully realised'. The key for the empirical liberal theorist is 'to understand the balances between conflicting and self-interested concerns that can exist in particular stages of international history'.

Co-operative, because central to the realisation of greater human freedom is increased international co-operation between states and other international actors. Without co-operation it is impossible to capture the benefits of interaction, interdependence and the opportunities for realising greater peace, welfare and justice.

Modernist, because liberals believe that international relations are transformed by several elements that modernise the world, such as liberal democracy, international interdependence, cognitive (scientific) progress, international institutions and international sociological integration (between persons and groups). The combined influence of the spread of those elements, liberals believe, 'has introduced or enhanced the possibility of a dramatic improvement in the moral character and material welfare of humankind' (Zacher and Matthew, 1995: 109-110).

Michael Doyle, in another influential account, also focuses on a range of characteristics when describing liberalism in IR. He argues liberals put emphasis on the possibility for global peace, through a greater role for international organisations and international law which diminish the influence of war and diplomacy. For this to happen the number of liberal societies, defined as democratic states where respect for individual negative and positive rights is of central importance, must be increased. Following Waltz's [positivist, EvdH] levels of analysis approach (Waltz, 1954), Doyle distinguishes between liberals who explain international relations with 
a focus on human nature, domestic society or the international system (Doyle, 1997: 205-212).

A successful English textbook also characterises liberalism in international affairs as internationalist, in praise of international organisation and aiming at peace. Part of liberal IR theory are the alleged peaceful effects of expanded international commerce, while the protection of human rights and a need for humanitarian intervention also play a significant role (Burchill, 2005). This is fully in line with other introductory accounts from past and present, like Brown's text (2001: 22-30, 153-157), the most important Dutch textbook (Koch et al., 1994), Viotti and Kauppi (1987), Jackson and Sørensen (2003) and the way M.J. Smith (1992) presents liberalism in an account aimed at a more advanced readership.

Like Doyle, Dunne follows the Waltzian scheme of the levels of analysis approach when introducing liberalism in one of the world's best selling textbooks. He rejects a separation between domestic and international liberal theory, which is in line with the approach taken in this thesis. But in contrast to it, he sees the core ideas of liberal thinking in IR as follows: peace between democratic states (to be discussed below); the positive relation between free trade and peace; the existence of a harmony of interests between people; the importance of creating international institutions and for some (idealist) liberals even world government; the peaceful effects of international integration and interdependence, or the interconnectedness between states and other international actors (Dunne, 2005).

All writers on liberalism in IR (rightly) underline that there is not one single liberal theory of IR. In their efforts to present different liberal theories, they almost always overlook the ideas of the classical liberals. Even when they explicitly attempt to make a connection between liberal political theory and international relations theory. IR theorists tend to be imprecise and selective in their presentation of liberalism (for example Freedman, 2005; Panke and Risse, 2007; Williams, 2006a), focusing on one viewpoint, a particular element or a deficient number of thinkers. It is no wonder that classical liberalism is notoriously under-theorised and erroneously presented in IR. To further clarify this, the rest of this chapter is devoted to establishing the main differences between the classical liberal IR theory and common forms of liberalism in IR. The aim is not to discuss all these differences at length, but to provide enough detail to be able to determine 
where and how the classical liberal IR theory differs from the established liberal views in IR.

\section{Liberal internationalism}

Liberal internationalism is one of the oldest liberal IR-theories (Williams, 2006a: 21) and it argues to change the world through the formation of international organisation and the design and enforcement of international norms and rules, to facilitate peaceful change, disarmament, and the arbitration of disputes. It also referred to as idealism or liberal idealism (Dunne, 2005: 195). In Britain, its has mainly consisted of a combination of Cobden's appeal for free trade and political non-interventionism, Bentham's utilitarian emphasis on international law and Kant's emphasis on a transnational interstate organisation (Ashworth, 1999: 4, 22-42). Hence, liberal internationalism does not have a clear base in classical liberal thought.

The idea behind the creation of international organisations is that they help to overcome international anarchy and might even serve to accomplish economic redistribution and international justice (Long, 1995; Long, 1996). Despite the realist criticism of scholars like Carr and Morgenthau in the 1930s and 1940s, liberal internationalism remained important after the Second World War. The emergence of the Bretton Woods System and the UN and its satellite organisations are evidence of this (Hill, 1989).

Liberal internationalism aims at the establishment of international order, but unlike classical liberalism it rejects the workings of the institutions of Grotian international society. Diplomacy is criticised, war denounced, as is the balance of power mechanism, which is seen as a major cause of international disorder because of its alleged instability and stimulation of competition between states. This ultimately leads to war (Wight, 1995: 200). A clear example is the famous Fourteen Points Speech of President Wilson, the most important American liberal internationalist. He demands 'open covenants of peace, openly arrived at', free international economic transactions and freedom of the seas, the reduction of national armaments, a qualified adherence to the principle of self determination for 
colonised peoples and the formation of a general association of nations, 'for the purpose of affording mutual guarantees of political independence and territorial integrity to great and small states alike' (Wilson, 1918). A contemporary therefore linked Wilson to Kant:

'So sehen wir die Völkerbundsgedanken des Deutschen Denkers und die durch mehr als ein Jahrhundert davon getrennten Ideeen des amerikansichen Staatsmanns, trotz alle Verschiedenheiten [.....] in allem Wesentlichen einander nah verwandt' (Vorländer, 1919: 67-85; also see Jackson, 2005: 63).

Another difference between classical liberalism and liberal internationalism is that the latter thinks free trade unites people through peaceful exchange and that democracy breaks the power of the elites over foreign policy. If legitimate domestic orders can be established around the world, peace follows swiftly and automatically. Then peace instead of war becomes the normal state of international affairs. This relies very much on Kant and his ideas on perpetual peace, to be discussed below. Liberal internationalists distinguish militaristic and undemocratic elites who are seen as the major forces behind the outbreak of wars, waged with safeguarding their own interests as a primary goal. Territorial conquest serves to extend the power and wealth of these elites. In contrast, the 'common' people are by nature peaceful, because they realise their interests are best furthered in peace, through the expansion of commerce. This allows for the peaceful accumulation of wealth, enhances the mutual understanding between people and creates a mutual international interest in keeping peace. Liberal internationalists expect that the expansion of domestic democracy and international trade will eliminate war (Burchill, 2005: 55-64). Public opinion will act as a restraint on international conflict, through the democratic decision making process. The 'inherent moral good sense of the people' limits the room their leaders have to execute belligerent policies (Clark, 1989: 212-214).

Liberal internationalism clearly believes in the possibility of lasting change in the international realm. Both the sources and the aims of liberal internationalism differ from classical liberalism, which sees only a limited albeit important role for governments in international afffairs. Most liberal internationalists oppose military interventionism and rely on the spirit 
of the people and the excellence of its economy for state survival (Waltz, 1954: 97-123). In classical liberal eyes, liberal internationalism relies on an unwarranted optimistic view of human nature and overlooks that there is no fundamental difference between the elite and the rest of the people when it comes to foreign affairs. Liberal internationalism unduly favours rationalism and constructivism in the form of international institutions. Instead of spontaneous order it aims to create order through international bureaucracies, without noting the dangers to individual liberty. Mises' and Hayek's criticism of the League of Nations is a good example of the differences between the two liberal theories.

\section{Neoliberal institutionalism}

The idea that international organisation can promote order and peace has been dominant in liberal IR in a number of different ways. Liberal institutionalism, also called neoliberalism or neoliberal institutionalism, is a modern variant of liberal internationalism. As the name indicates, liberal institutionalists focus on the possibilities for states to co-operate through international regimes and institutions. They differ from liberal internationalists in that they accept the importance of states as international actors and the anarchical condition of the international system. They think that states co-operate in order to achieve absolute gains, not out of idealism and are generally less idealistic than the liberal internationalists.

At first, their focus was on the positive effects of international integration, especially in Europe. If states pool their resources and even surrender some of their sovereignty to create regional (economic) organisations, peace and prosperity will be the result (Lamy, 2005: 213). Early examples of liberal institutionalism are theories of regional integration (Nye jr., 1988: 236-240), like functionalism, which is closely associated to David Mitrany and his contention that international reform depends on transnational association instead of interstate mechanisms (Franceschet, 2002: 75-76; Long, 1995: 317). Mitrany believed in international planning and the possibility of lasting peace through the creation of technocratic, function-specific international organisations (Ashworth, 1999: 76-105).

In the 1970s, a newer variant of liberal institutionalism was intro- 
duced by amongst others, Keohane and Nye, called transnationalism. Put briefly, they assert that once states, groups and individuals get more entangled in all kinds of cross-border relationships (political, economic, social), a situation of 'complex interdependency' will emerge. Due to the variety of actors and the existence multiple channels that connect societies, military security no longer dominates the political agenda and is no longer a viable policy option for states. This will stimulate or even ensure peace (Keohane and Nye, 1989: 24-25).

Sometimes a distinction is made between liberal institutionalism and neoliberalism, mostly on methodological grounds. The neoliberals are seen to adhere more strictly to methodological positivism and are more rationalist in their premises (Martin, 2007), just like their neorealist opponents in the so-called 'neo-neo-debate', which dominated IR for several decades (Lamy, 2005; Baldwin, 1993). Yet the basic ideas of neoliberalism and liberal institutionalism are alike, which warrants their inclusion in one section here.

International organisations and regimes are said to lower the likelihood of 'cheating' in the international system, because they build a system of rules and conventions for co-operation and the punishment of defectors. Therefore all participants gain from international co-operation in absolute terms (Grieco, 1993: 121-135). Regime theory asserts that there are social institutions in international affairs, that govern the actions of those involved in specific activities or sets of activities. These may be rules or formal agreements, in all sorts of areas, with many different functions (Young, 1989: 11-13). The bottom line of formal and informal international cooperation is to make the international arena more predictable, less anarchic and focused on military conflict, pluralist in terms of actors and ways of contacts between societies, and therefore less prone to wage war.

Classical liberals do not object to multiple international channels and complex interdependence and do not principally deny the value of international agreements on specific topics or general rules of international law. Yet the idea that international governmental organisations always promote peace is far too constructivist and one-sided in their eyes. Liberal institutionalists are too eager to expect positive results from international organisation. They appear to overlook the possible detrimental effects to individual liberty that international organisation poses (the Misesian and 
Hayekian objections to the EU and the UN come to mind) and underestimate the friction that results from international bargaining and negotiation. The idea that war can be abolished through international organisation is also too not realistic according to classical liberals, because human nature and the distribution and balance of power remain relevant factors in world politics.

\section{Embedded liberalism}

Another variant of liberal institutionalism is Ruggie's 'embedded liberalism'. It central claim is that after the Second World War world order was characterised by a 'grand political compromise of laissez faire liberalism in the international economy and domestic political interventionism that legitimated and stabilised the multilateral economic order for some fifty years' (Bernstein, 2007: 5). The compromise is based on the idea that it is possible to trade off the perceived advantages and disadvantages of international co-operation. Governments participate in the international economic system, which is more or less founded on liberal principles. They do not surrender power over their national economies and therefore keep the ability to implement social arrangements aimed at 'softening' the alleged negative effects of international liberalism. Ruggie fears that globalisation will enforce 'disembeddedness', because continued competition between states allows less room for national adjustments. This results in conflicts over national economic arrangements, the denationalisation of significant economic decisions and decreases the ability of governments to live up to the promises they made in the domestic situation (Ruggie, 2002; also Bernstein and Pauly, 2007).

The basis of this theory is economic, but the focus is political. It is argued that under American leadership the world was opened for trade and intergovernmental management of exchange rates in finance. The political goal was to create a world order underpinned by multilateralism. This entails that national governments remain sovereign, but the exercise of that sovereignty is channelled and made more open and accountable through participation in all kinds of multilateral institutions, like the UN, IMF and World Bank (Bernstein, 2007: 6-7). There is no need to elaborate on the 
details of this theory. Suffice it to note that as an IR-theory is relies on the same logic as liberal institutionalism, which leads to the same counterarguments from the classical liberal perspective, as discussed above.

In addition, classical liberals, as shown in the writings of Hayek and Mises, disagree with Ruggie's assertion that the post-war world was characterised by laissez-faire liberalism. They would concede there was a bit more economic freedom than in the previous decades, but this did not come anywhere near the classical liberal ideal. Also, as Sally points out, from a classical liberal perspective, embedded liberalism is 'an unlikely congress of antithetical ordering principles to support a liberal international economic order'. National mixed economies are seen as an unhealthy compromise of command and market economy, and a source of international illiberalism, for example in the form of trade protectionism and capital controls. It is impossible to promote a classical liberal international economy, without classical liberal national economies, or as he calls it 'liberalism from below'. Negotiated governmental cooperation, or 'liberalism from above', is problematic, because international policy coordination, characterised by reciprocal negotiations, is often just plain interventionism. There can be no design of the international political economy by governments. Hence, for classical liberals, unilateral liberalisation and institutional competition are the only feasible options (Sally, 1998: 195-203).

\section{Liberal democratic peace}

As one of the hottest debated topics in IR, the literature on 'democratic peace', the idea that established democracies never go to war with each other, is immense. Most interesting for the purpose of this thesis is that the idea is sometimes also referred to as 'liberal peace', on the basis of the claim that liberalism is the main foundation for democratic peace (Owen, 1996: 116-133). Michael Doyle, one of the earliest and most influential proponents of democratic peace, detects a large influence of liberalism on international affairs, explicit in its rejection of the balance of power, the preference for non-interventionism and the idea that citizens should be free to establish international ties without government interference. This results in 'a liberal zone of peace, a pacific union' (Doyle, 1996: 3-27). Ex- 
cept the last element, this portrayal of liberalism does not do justice to the classical liberal viewpoint.

Most researchers of democratic peace use the label 'liberal' in a rather loose way. The liberalism these scholars refer to originates from a rather select group of thinkers. Although their interpretation of the ideas of the German may be wrong (Jahn, 2006a), Kant is their main source of inspiration (see MacMillan, 2006: 52; Doyle, 1997: 251-300; Oneal et al., 2003). Other writers add a select group of other thinkers. For example, Mousseau, Hegre and Oneal include Angell (2003), McDonald brings in Cobden and Schumpeter (2004), while Deudney (2004) underlines the additional importance of Montesquieu and the American Founding Fathers. A detailed analysis of the thought of these thinkers is nearly always absent and the differences between these thinkers are hardly ever touched upon. The ideas of, for example, Smith and Hume are mostly absent from the discussions, despite there canonical status in liberal political theory.

MacMillan explicitly singles out 'left-liberalism', or social democracy, as the relevant liberal variant in the debate on democratic peace (2004: 180). He is also one of the few theorists who takes into account the ideology of many of the politicians allegedly 'responsible' for the liberal democratic peace. In post-war Europe for example, these were mainly of a socialist or Christian-democrat persuasion. To include them in a theory about liberal democratic peace means at least that the term liberal is used in an over-stretched way.

A prominent example of this overstretching is offered by the work of Owen. He defines a liberal state as 'having two domestic institutions: freedom of discussion and regular competitive elections of those empowered to make war' (1997: 3), which I his view ensures rational laws and decision making, and lead liberal states to refrain from waging war against one another (Owen, 1997: 19-20). This is a very rudimentary definition of liberalism, unsound from a political theory perspective. The emphasis on rationality in liberalism is also found in other works, for example MacMillan's writings. Explicitly arguing against Bull and other English School theorists, he claims that liberals are people who believe in the power of reason, who have faith in the reconcilability of interests. They allegedly refuse to accept war as a natural or necessary part of international relations. In his view, international pacifism is integral to liberalism (MacMillan, 1998: 
13-22). Russett and Oneal (1997) join him in this respect, by arguing - at least partly erroneously - that 'the classical liberals', such as Turgot, Smith and Paine, were right about the pacific benefits of trade.

This is not the place to discuss the liberal credentials of all the different thinkers mentioned in the preceding paragraphs. In the following brief introduction of Kant's international political thought it will be attempted to clarify the contrast between the liberalism in the democratic peace debate and classical liberalism. Kant is in high demand by IR theorists and most of the references to him are based on his essay On Perpetual Peace, first published in 1795 . In it he sets out to describe the possibility and the conditions for world peace between states. He introduces a number of 'preliminary articles', like the obligation to make peace without secret motives for a future war and to gradually abolish standing armies. It is prohibited to sell or exchange a state, and to interfere in other states' affairs. The preliminary articles are complemented by three definitive articles. The first prescribes that all states shall have republican constitutions, in turn founded upon the following principles: freedom for all members of society, dependence on one single common legislation and legal equality for everyone, and government based on a representative system [although he did not foresee or propagate a parliament with modern formal powers versus the executive]. The second prescribes that the right of nations shall be based on a federation of free states. Kant explicitly excludes the possibility of establishing one international state. Instead, 'a pacific federation of peoples' should be formed, to eliminate all wars forever. The third prescribes that there is a cosmopolitan right, which is limited to mean that every stranger has a right to be treated with hospitality when entering another state's territory. In two supplements and an appendix, these articles are further elaborated, for example by the claim that freedom of trade and commerce would further peace (Kant, 1991). Inevitably, there have been many different interpretations of On Perpetual Peace and Kant's intentions in writing it (see Easley, 2004; also Jahn, 2006a), which only appear to have strengthened its position as a central IR-text.

The controversy over Kant's ideas on international relations is stimulated by his inconsistency in other essays, most notably The Idea for a Universal History, Theory and Practice and The Metaphysics of Morals. For Hurrell there are two main interpretations. The statist view holds that Kant was 
primarily concerned with peaceful interstate relations, he did not want to transcend the state system, nor work towards a world government. His sole aim was to improve the existing system. The cosmopolitan view stresses the universalist, republican intentions of Kant and his plea for a world federation of states is regarded as much more than just a loose system of co-operation (Hurrell, 1990).

This divergence in interpretations also applies to other parts of Kant's positions on international affairs. To some scholars, Kant seems to reject the just war tradition. Human nature is decisive to reach peace and Kant has no immediate hope that a global civil society will soon emerge (Williams and Booth, 1996: 80-81). Others state that Kant has far more in common with the international law tradition of Grotius, Pufendorf and Vattel, than his assertion that they were all 'sorry comforters' would lead one to think. He was clearly influenced by Vattel, even though he rejected the natural law foundation of international law for its alleged promotion of warfare (Covell, 1998: 93-100). More consensus appears to exist about Kant's rejection of a global Leviathan (Tuck, 1999: 230), the balance of power and Kant's hope that the increasing cruelty and destructiveness of war will make people realise that peace is the only viable option in world politics (Knutsen, 1997: 126). Also, Kant is widely seen as revolutionary, as he desires to improve the current political state of affairs and as cosmopolitan, due to his emphasis on the existence of a society of all people (Wight, 2005: 71-74; MacMillan, 2006; Franceschet, 2002: 9-22).

Most of the Kantian elements clearly relate to the world society tradition in the English School, introduced in chapter one. It has less to do with the classical liberal IR theory. The liberalism in the democratic peace debate is concerned with individuals and democratic principles in domestic politics, yet the foundations of the liberal peace are human rationality, man's capability of maintaining peace, the ability to get rid of power politics and the peace promoting effects of trade. There is much overlap with the liberalism in IR previously discussed and far less agreement with the classical liberal international relations theory introduced in the first part of this chapter. 


\section{Invented liberalisms}

Besides the main theories discussed above, many different and new variants of liberalism were introduced in IR theory. Here they are labelled 'invented liberalisms', since each of them may be linked to one or more liberal ideas, but they all suffer from a lack of sound grounding in liberal political theory. This is another example of the inaccurate treatment of liberalism in IR. Nevertheless, these ideas are prominent in the literature and will therefore be briefly discussed in relation to classical liberalism.

Doyle is a major inventor of liberal traditions. In an often cited article he contends that there are 'three distinct traditions of liberalism, attributable to three theorists: Kant; Schumpeter, a brilliant explicator of [..] liberal pacifism and Machiavelli, a classical republican whose glory is an imperialism we often practice' (Doyle, 1986: 1151-1152). He fails to provide much evidence that these three are founders of distinct liberal traditions, although a Kantian tradition indeed exists. In his influential book that partly deals with liberalism in IR he extends his argument (Doyle, 1997: 205-311). Locke and Bentham are seen as founders of liberal institutionalism (Doyle, 1997: 213-229), but he clearly overlooks the realist elements in Bentham's international relations, as discussed in chapter 5 (based on Hoogensen, 2005). His commercial pacifism, by other writers referred to as commercial liberalism or trade liberalism, claims that the idea of a positive relation between free trade and peace is in important ways based on the work of Adam Smith (Doyle, 1997: 230-250). This is erroneous, as shown in chapter four.

Republican liberalism is commonly used in IR literature, but it is just another name for the idea of a link between democracy and peace.

Sociological liberalism refers to transnational interaction and international integration (Baldwin, 1993: 4) and is therefore another way to refer to liberal institutionalism. The adjective sociological appears to refer to the importance attached to relations between individuals as opposed to relations between states (Jackson and Sørensen, 2003: 109-111). It is not clear why adding this adjective is an improvement, as liberalism certainly comprises these relations as well. The same applies to the term interdependence liberalism', which refers to the neoliberal institutionalism and functionalism (Jackson and Sørensen, 2003: 112-116). 
The common use of a tri-partition between commercial liberalism, sociological liberalism and republican liberalism owes a lot to Keohane and he justifies it with the (erroneous) claim that 'liberalism does not purport to provide a complete account of international relations'. He traces all these three liberal variations to Kant and argues for a synthesis of commercial and republican liberalism, which he then proposes to call 'sophisticated liberalism'. This term is meant to cover a combination of the idea of the alleged peace promoting effects of trade and an international political framework of rules and institutions (Keohane, 1990: 173-185). It is a rendition of liberal internationalism and liberal institutionalism, which, as discussed, includes only a part of the liberal ideas on international relations.

Zacher and Matthew (1995: 120-140) add another three liberal varieties. Military liberalism, which claims that the deadly power of new military technologies creates greater mutual interest in peace and co-operation and facilitates international economic co-operation. Cognitive liberalism is about rationality in the behaviour of individual actors, therefore it calls for increased levels of knowledge, especially about democracy, which will promote international peace. Institutional liberalism takes the body of international institutions as an independent variable. Moravcsik (1997) also develops three variants, called ideational liberalism, commercial liberalism and republican liberalism, which partly overlap with the ones introduced above. All these liberalism are not mutually exclusive, not as IR theories, nor as allegedly different forms of liberalism. Their inventors also fail to make explicit how they relate to liberal political theory.

There are a few exceptions. Interestingly, Doyle not only invents liberalisms, he also distinguishes between the foreign policy options of classical and social liberals. Put very briefly, the former lean more towards power politics and the latter attempt to construct pacifist global justice (Doyle, 1996: 30-48; Doyle, 1986: 1155-1157). Richardson (1997) claims that there have always been 'contending liberalisms' (also see Sørensen, 2006), rightly stating that the differences between classical and social liberalism also apply to international affairs. Yet, like Franceschet (2002: 103-130), he holds a very clear, but hardly substantiated bias against classical liberalism. He calls it 'neoliberalism' and portrays it as the bulwark of the established order, legitimising privileges and upholding inequalities like structural unemployment and social deprivation, at the cost of the margin- 
alised in the developing world. In contrast, social liberals are a liberating force promoting equality of rights (Richardson, 2001).

The explanatory power of this bewildering variety of liberalisms in IR is very limited. With classical liberalism they seem to have a concern for individuals and free international economics in common. Yet most liberal IR theories regard humans as rational beings, are arguing in favour of international governmental organisation and almost uniformly regard liberalism as a peace theory. All the adjectives used are unknown in liberal political theory, and add to the confusion about liberalism in IR. Most IR scholars call something liberal when free trade, free movement of persons, or nonstate relations and non-state actors are in play. Most theorists do not clarify the political philosophy foundations of their theory. At best, like Andrew Williams in Liberalism and War (2006a: 21-69), some names of philosophers are mentioned and some highlights of their work sketched, but this is not done from a political theory perspective. This is an important reason for 'the inflation' of the term liberalism in international political theory: if everything is called liberalism, liberalism becomes meaningless. It is also an example of the lack of synthesis between political theory and IR theory.

\section{Conclusion}

The classical liberal IR theory is a consistent application of domestic classical liberal elements to the international realm. Its concern for individual freedom, natural rights and natural law, a limited state, spontaneous order and the rule of law all find expression in a related element of the classical liberal IR theory. It has most in common with the pluralist Grotian conception of international order in English School theory, but also has some distinct additional characteristics.

While all of its separate elements needs further analysis, it is clear that it is also a radical IR theory. There are no other theories that combine a systematic concern for the enlargement of individual freedom, the recognition that international conflict cannot be abolished, and a refusal of movements towards eternal peace, cosmopolitan society or other Utopias. It is also characterised by scepticism about the idea that trade leads to peace, although classical liberals recognise that trade is very important for devel- 
opment and the general increase of welfare in the world. Governmental constructivism at the international level, either in the form international organisations or development aid is rejected. The state remains a central actor in IR and its participation in, and defence of, the institutions of international society are the best insurance for the largest degree of order possible in international relations. Therefore it is the best way to guarantee and expand individual liberty.

With these characteristics classical liberalism clearly differs from the other liberalisms in IR. As of yet, liberal IR theorist do not acknowledge its existence as an independent, comprehensive theoretical variant. 


\section{8 \\ Conclusions and Ways Forward}

A large part of the liberal puzzle has been solved in this thesis. It is now clear that IR scholars have ignored classical liberalism as a tradition and largely misinterpreted the international thought of the Hume, Smith, Mises and Hayek. There are no good reasons for this neglect, even though their thought shows some inconsistencies, but these can be found in the work of almost any great thinker. The result is an unbalanced and to an extent ill-informed presentation of liberalism in IR. The most important reasons for this omission and its implications for academics of IR and liberalism are the subject of this concluding chapter. Along the way, answers to the research questions and themes set out in the introduction are provided. The chapter closes with recommendations for future research.

\section{Conclusions}

This thesis makes clear that IR theorists need to readjust their view on the liberal tradition. They regularly overlook one of its most important variants, classical liberalism, most basically because they seem unaware of its existence as a separate liberal tradition.

The application of the methodology set out in the introduction enabled the distillation of the classical liberal IR theory presented in chapter seven. After defining classical liberalism in chapter two, the classical liberal credentials of the four thinkers were established in the subsequent chapters. The ideas on international relations they shared and that were consistent with domestic classical liberalism were used as inputs for the IR theory. It is evident that domestic and international classical liberalism are 
concerned with the same ideas and both work to advance the expansion and protection of the largest degree of individual liberty.

The previous lack of knowledge on this side of classical liberalism also serves as evidence for the existence of a divide between political theory and IR theory. Although only the writings of its most prominent thinkers could be studied, the analysis makes clear that there is a classical liberal tradition in the first place. Its main features, as discussed in chapter two, are its base in non-religious natural law, the prime importance it attaches to social and political individualism and freedom, a strong belief in spontaneous ordering processes, the rule of law and a limited state. The classical liberal plea for a limited state separates them from the social liberals, who favour a much bigger governmental role, and from many libertarians who do not see a role for the state at all. These characteristics also lead to the exclusion of a number a thinkers sometimes associated with classical liberalism, most notably Hobbes, Kant, Bentham and Mill. All four thinkers analysed are classical liberals. Smith and Hume are influenced by each other and are among the founders of the classical liberal tradition. Mises and Hayek both make clear that they are indebted to the two Scots, that they think of themselves as writing in the same tradition and that they want to further develop this type of thought. Classical liberalism is a full fledged tradition as defined in the introduction.

There is a number of reasons for this 'liberal knowledge gap' in IR. While the thought of the natural law tradition, and Grotius in particular, is an established part of IR theory, the ideas on international relations within the wider natural law tradition have been neglected. The oversight of classical liberalism is one of its results, which is related to the common error of IR scholars to narrow down the Enlightenment to Kant and Rousseau.

As indicated in the introduction, the dispersed way the four classical liberals write about international relations probably did not stimulate research either. If read in a non-comprehensive way, some of their ideas might appear either very radical (no development aid) or conventional and time-bound (in favour of the balance of power in the 18th century). For some academics this may be enough reason not to pay much attention to these authors or their ideas, but this is a mistake nevertheless. The picking and choosing that occurs in IR lead to a rather inaccurate picture. The novelty of the classical liberal theory of international relations is more obvious 
when presented as a whole. It differs from other liberalisms and, as will be indicated below, also adds new viewpoints to the Grotian tradition within the English School.

Academic pigeon holing is another part of the explanation. Since Smith is mainly known for his economics, he is only referred to in the light of international economic relations. On a smaller scale the same applies to Hayek, while Hume is almost exclusively referred to in discussion about balance of power politics. As discussed in the last section of chapter three, his essay on this topic may be said to be part of the IR canon, but his other writings are mostly ignored. It is another sign of the inaccurate way IR scholars deal with the history of ideas. Even worse, this bad practice has found its way into IR text books, leading to the inaccurate teaching of students. To be fair to the IR community, this development is also stimulated by scholars in other academic disciplines. For example, the philosophers often just pick out the parts of writings they found most interesting, especially in the case of Hume. Scholars of classical liberalism are predominantly economists, which in practice means they mainly restrict themselves to the economic parts of the work of Smith, Mises and Hayek.

However, it must be emphasised that not all erroneous classifications or interpretations of the thought of the classical liberal thinkers are related to academic specialisation. It is hard to get around the impression that many IR-authors routinely refer to famous thinkers without a sufficient knowledge of their ideas. They seem to just copy main stream opinion. This study shows that it is possible to avoid such mistakes if only one is prepared to analyse the writings of the thinkers in full.

Besides urging IR academics to reassess the scope of the liberal tradition, the present analysis also calls for a reappraisal of the views on the international relations of all four classical liberals analysed. In terms of the English School, Hume and Smith are Kantians nor realists, Mises and Hayek not Kantian. All of them are Grotians, mostly of a pluralist persuasion. In chapter three it was concluded that it is no anachronism to see Hume as an early representative of the international society tradition. Chapter four showed Smith has far more to say about international relations than the issue of free trade, although he is often misinterpreted even on that point. He is far more belligerent than most IR scholars think, yet a much stronger supporter of international society than argued by Andrew 
Walter, probably the most prominent writer on his international politics. The overview in chapter five made clear that Mises is more than just an economist. While not always analysing international affairs in a sufficiently broad scope, his ideas on this topic are much richer and less directed against war than is often taken for granted. The discussion in chapter six showed that Hayek wrote about international affairs throughout his career, that he was a consistent federalist, and like Smith had a keen insight into the importance of international order for individual freedom. Therefore he had a positive opinion on balance of power politics and emphasised the importance of defence by the state, sometimes in a hawkish fashion.

The synthesis of the international affairs of Hume, Smith, Mises and Hayek, in chapter seven, lead to the introduction of a new classical liberal IR theory. It starts with the recognition that classical liberals apply the same principles to domestic and international politics. All politics is seen as purposeful individual behaviour, just like other forms of human action. This means that human nature is important in determining the possibilities for change in international relations. The realistic assessment of man as both rational and largely under the spell of emotions leads to three assumptions that are of special relevance to international relations. First, the impossibility to rule out violence and conflict between humans. Second, that it is also impossible for humans to gather and process enough information to construct or plan for some ideal social order. Third, the individual attachment to the state or the nation, leading to a divide between 'them' and 'us'. These three combined ensure that the state remains the prime actor in international relations, with the same aim as in domestic politics: to enlarge individual freedom. It also means that contrary to the perceived liberal wisdom classical liberalism does not believe that trade promotes peace. The principle of state sovereignty is important, but not of absolute value. If a society of states somehow does not emerge spontaneously, for example due to ethnic strife, federalisation is a good solution, for example in Europe.

Classical liberals assert a safe and stable order is a necessary precondition to attain greater individual liberty. Leaders of states have to provide the largest degree of order possible in the anarchical international society, where the prime societal elements are diplomacy and international law. Yet the preservation of international society also depends on the balance of 
power and sometimes war. Following its natural law roots, classical liberal IR theory accepts or even endorses war when fought on just grounds and in a just way. The classical liberal demand for a limited state also finds expression at the international level, through the rejection of imperialism, development aid, most intergovernmental organisations and positive international law, for example as the result of a broad interpretation of economic and social human rights. Classical liberals favour a limited state both in domestic and international politics.

Classical liberal IR differs substantially from the other liberalisms in IR, which are commonly associated with idealists, utopians, cosmopolitans or Kantians. For the classical liberals there is no need to think that international politics is limited to either power motivated actions within a system of states, or the perspective of a world society. The latter is not attractive, due to the imminent danger to individual freedom and the promotion of a scramble for power at the transnational level between nations. The state may be an imperfect, yet acceptable form of organisation generally capable of protecting fundamental liberties. That cannot be assumed in the case of international organisations or a world government.

Inevitably, this position has consequences for both IR theory in general and English School theory in particular. There are different liberalisms in IR theory, which are mostly concerned with the expansion of international governmental organisation, the alleged peace enhancing effects of trade and the extension of positive international law. The main philosophical inspiration is provided by a combination of the (alleged) thought of Kant, Bentham and Cobden, while Mill's embrace of empire and nationalism looms in the background. As shown in chapter seven, the rather loose way IR theorists use political theory partially results in a confusing plethora of invented liberalisms without explanatory power. It is also clear liberalism in IR can almost exclusively be traced back to the social liberal variant introduced in chapter two. This is perhaps not surprising given its dominance in US political theory and the overwhelming presence of American scholars in IR theory. However this type of liberalism is only one part of the liberal story, in the absence of the classical liberal variant. To provide a more balanced view, this study therefore seeks to 'introduce the classics'.

As indicated above, this thesis offers several new insights for English School theorists, which follow from the newly established relation be- 
tween classical liberalism and the Grotian tradition. Within this tradition, Hume, Smith and Hayek are firmly on the pluralist side and even Mises predominantly leans to this position. Overall, this greatly strengthens the pluralist perspective, which appears to have become a minority position, because many current English School theorists aim to advance the solidarist and Kantian perspectives. The connection between the classical liberal and Grotian traditions also makes clear that the position of the individual in English School IR is more complicated than often thought. One cannot simply say that individualism is limited to the Kantian tradition, because the latter tradition regards the world as a community of individuals, or civitas maxima. At best this is one element in the relation between individualism and world politics. Classical liberalism therefore 'rescues' the individual from the Kantian community of humankind. Feelings for the state are seen as a regular part of human nature. States are the prime actor in international relations, even though they also constitute the largest danger to individual liberty. Yet in a world society or a state system the threats to individual freedom are even bigger.

This thesis also contributes to the underdeveloped areas in English School theory which were outlined in the introduction. The most obvious classical liberal element is the emphasis on capitalism. The twin ideas of spontaneous order and free market economics actually lead to rather radical proposals for change in current world politics. Not surprisingly, there is an argument for a extended role for free trade, which is perceived not only to have great welfare enhancing effects, and is also associated with positive cultural exchange. This promotion of free trade goes hand in hand with a strong dislike of international economic governance. Classical liberals reject most forms of governmental interference and development aid. The latter is not seen as an expression of solidarism, it only supports bad governments with bad policies, infringing individual freedoms. Classical liberals assert the current state of international affairs is still largely characterised by mercantilism, constructivism and state expansion beyond their limited number of tasks. For Grotians this poses questions about the role and justice of state action, possible restrictions on positivist international law and the limits of international governmental organisation.

The idea of a limited federation is added to the discussion on European integration within the English School. In a true Smithian spirit, both 
Mises and Hayek firmly support the development of a European federation and they do not see a reason to exclude classical state tasks like foreign policy or defence. However, the classical liberal support is conditional and limited to a decentralised European federation, with a small number of tasks at the supranational level. This means for English School theorists that questions about the future of Europe cannot be exclusively seen in terms of a debate of Grotian solidarists and Kantians versus the realists. There is a possible via media role for pluralist Grotians as well. The classical liberal position also adds fresh ideas to the current debates on the future of the EU.

The neglect of political theory by the English School is largely confirmed in the current analysis. The analysis of classical liberalism shows that more attention to this field may lead to new areas for research. For a School priding itself on a historical approach it is certainly surprising that there has not been more attention to the history of ideas. This thesis also indicates that English School theory and liberalism in IR are more closely connected than previously understood, which may lead to a repositioning of the Grotian tradition.

Last but not least, this thesis strengthens the evidence for the existence of a Grotian tradition as such. In IR, research of the influence of Grotius and the natural law tradition has hardly ever followed the path leading to the thinkers of the Scottish Enlightenment and beyond. Therefore its influence has largely remained uncovered, despite some pioneering work by some political theorists. This approach is too narrow as far as IR is concerned. When thinkers outside the IR canon are analysed, the claim about the invented status of traditions evaporates. Therefore, the conclusion here is that it is possible and useful to use traditions in IR research.

In short, this study sheds new light on a number of fields. The definition of classical liberalism has been refined and its existence as a tradition in political philosophy confirmed. The knowledge of the political philosophy and the ideas on international relations of Hume, Smith, Mises and Hayek has been enhanced. Classical liberalism is introduced into IR theory and it provides a critique on other forms of liberalism. The study strengthens the evidence for the existence of a Grotian tradition and introduces several new elements to English School theory. IR theorists need to renew their ideas on liberalism. 


\section{Way forward}

Despite these results, a thesis of this scale cannot be conclusive, there is still a demand for further inquiry. Expanded research on the views on international relations of a larger number of classical liberal thinkers is a first suggestion. This is needed to widen the basis of the classical liberal tradition in IR theory.

Also, the classical liberal IR theory requires more work. As indicated in chapter seven, all of its constitutive elements are in need of further elaboration. For example, the precise relation to the just war tradition, the role and limits of humanitarian and military intervention and more details on the restriction of international governmental organisations and the optimal number of tasks of the European Union. Classical liberals may want to work out some of their current internal differences in opinion, for example on empire, immigration, intervention and the balance of power. There also remains work to be done on the relationship between the classical liberal IR theory and the libertarian positions in this field.

If a large part of this thesis may be characterised as 'The English School went to Scotland and Austria', it is clear that there must be far more thinkers, in more countries, whose writings warrant closer scrutiny. More work can also be done on the relations between the English School and individualism, capitalism and European integration, as well as the traces of the three traditions in the history of political ideas.

Whether the advances in knowledge presented here are a reasonable start for more research is of course for the reader to decide. However, this thesis ends with expressing the hope that the intellectual journey into classical liberalism may be continued. 


\section{Bibliography}

Acton, J. E. E. (1985a), Essays in Religion, Politics, and Morality.

Selected Writings of Lord Acton, volume III, edited by J. Rufus Fears, Indianapolis: Liberty Fund.

Acton, J. E. E. (1985b), Essays in the History of Liberty. Selected Writings of Lord Acton, volume I, edited by J. Rufus Fears, Indianapolis: Liberty Fund.

Ainslie, D. C. (1995), 'The Problem of the National Self in Hume's Theory of Justice', Hume Studies, XXI, 289-313.

Alderson, K. and Hurrell, A. (Ed.) (2000), Hedley Bull on International Society, Houndmills and New York: Palgrave Macmillan.

Anderson, B. (1996), Imagined Communities. Reflections on the Origin and Spread of Nationalism, London and New York: Verso.

Andrews, J. K. (Ed.) (1981), Homage to Mises. The First Hundred Years, Hillsdale: Hillsdale College Press.

Arblaster, A. (1984), The Rise and Decline of Western Liberalism, Oxford: Basil Blackwell.

Armstrong, D. and Farrell, T. (Ed.) (2005), Force and Legitimacy in World Politics. Review of International Studies Special Issue, Cambridge: Cambridge University Press and British International Studies Association.

Ashworth, L. M. (1999), Creating International Studies. Angell, Mitrany and the Liberal Tradition, Aldershot: Ashgate.

Aspromourgos, T. (1996), On the Origins of Classical Economics.

Distribution and Value from William Perry to Adam Smith, London and New York: Routledge.

Ayer, A. J. (1999), Hume, Rotterdam: Lemniscaat.

Baldwin, D. A. (1993), 'Neoliberalism, Neorealism, and World Politics', in Neorealism and Neoliberalism: The Contemporary Debate (Ed.

Baldwin, D. A.), New York: Columbia University Press, pp. 3-25.

Barbieri, K. (2005), The Liberal Illusion. Does Trade Promote Peace?, Ann Arbor: The University of Michigan Press.

Barnett, R. E. (2007), 'Libertarians and the War. Ron Paul Doesn't Speak for All of Us.' The Wall Street Journal, 17 July. 
Baron, S. (1981), 'Ungleichheit ist Nötig. Interview mit F.A. Hayek', Wirtschaftswoche, 6 March (Hoover Institution Archives. Hayek papers, box 109, folder 46).

Barry, N. P. (1983), 'Review Article: The New Liberalism', British Journal of Political Science, 13, 93-123.

Barry, N. P. (1987), On Classical Liberalism and Libertarianism, New York: St. Martin's Press.

Barry, N. P. (1994), 'The Road to Freedom. Hayek's Social and Economic Philosophy', in Hayek, Co-ordination and Evolution. His Legacy in Philosophy, Politics, Economics and the History of Ideas (Eds. Birner, J. and Van Zijp, R.), London and New York: Routledge, pp. 141-163.

Barry, N. P. (2000), An Introduction to Modern Political Theory, New York: St. Martin's Press.

Bartelson, J. (1996), 'Short Circuits: Society and Traditions in International Relations Theory', Review of International Studies, 22, 339-360.

Bastiat, F. (2007), The Bastiat Collection, Volume II, Auburn: Ludwig von Mises Institute.

Bauer, P. T. (1971), Dissent on Development. Studies and Debates in Development Economics, London: Weidenfeld and Nicolson. Bauer, P. T. (1991), The Development Frontier. Essays in Applied Economics, London: Harvester Wheatsheaf.

Bauer, P. T. (2003), 'Development Economics: The Spurious Consensus and its Background', in Roads to Freedom. Essays in Honour of Friedrich A. von Hayek (Ed. Streissler, E.), London: Routledge \& Kegan Paul, pp. 5-45.

Bauer, P. T. and Yamey, B. S. (1957), The Economics of UnderDeveloped Countries, Cambridge: Cambridge University Press. Baumgarth, W. (1976), 'Ludwig von Mises and the Justification of the Liberal Order', in The Economics of Ludwig von Mises. Toward a Critical Appraisal (Ed. Moss, L. S.), Kansas City: Sheed and Ward, pp. 79-99.

Beauchamp, T. L. (1998), 'Editor's Introduction', in David Hume. An Enquiry concerning the Pinciples of Morals (Ed. Beauchamp, T. L.), Oxford: Oxford University Press, pp. 7-53. 
Bellamy, A. J. (Ed.) (2005a), International Society and Its Critics, Oxford: Oxford University Press.

Bellamy, A. J. (2005b), 'Introduction', in International Society and its Critics (Ed. Bellamy, A. J.), Oxford: Oxford University Press, pp. 1-26.

Berlin, I. (1969), Four Essays on Liberty, Oxford: Oxford University Press.

Berns, L. (1987), 'Thomas Hobbes', in History of Political Philosophy (Eds. Strauss, L. and Crospey, J.), Chicago: The University of Chicago Press, pp. 396-420.

Bernstein, S. (2007), 'Power, Social Purposes, and Legitimacy in Global Governance', in Global Liberalism and Political Order. Toward a New Grand Compromise? (Eds. Bernstein, S. and Pauly, L. W.), Albany: State University of New York Press, pp. 3-22.

Bernstein, S. and Pauly, L. W. (Ed.) (2007), Global Liberalism and Political Order. Toward a New Grand Compromise?, Albany: State University of New York Press.

Bien Greaves, B. (1958a), Interview with Doctor Frederick Engel-Janosi, Washington (?), 8 March.

Bien Greaves, B. (1958b), Interview with Professor F.A. Hayek, Chicago, January 25.

Bien Greaves, B. (1977), An interview with Mrs. Ludwig von Mises, New York, March 21.

Billet, L. (1978), 'Justice, Liberty and Economy', in Adam Smith and the Wealth of Nations. 1776-1976 Bicentennial Essays (Ed. Glahe, F. R.), Boulder: Colorado Associated University Press, pp. 83-110. Biro, J. (1993), 'Hume's New Science of the Mind', in The Cambridge Companion to Hume (Ed. Norton, D. F.), Cambridge: Cambridge University Press, pp. 33-63.

Black, J. (1983), 'The Theory of Balance of Power in the First Half of the Eighteenth Century: a Note on Resources', Review of International Studies, 9, 55-61.

Blaney, D. L. and Inayatullah, N. (2006), 'The Savage Smith and the Temporal Walls of Capitalism', in Classical Theory in International Relations (Ed. Jahn, B.), Cambridge: Cambridge University Press, pp. 123-155. 
Bloomfield, A. I. (1975), 'Adam Smith and the Theory of International Trade', in Essays on Adam Smith (Eds. Skinner, A. S. and Wilson, T.), Oxford: Clarendon Press, pp. 455-481.

Blundell, J. (2002), A Tribute to Peter Bauer, London: The Institute of Economic Affairs.

Boaz, D. (Ed.) (1998), The Libertarian Reader, New York: The Free Press. Boesche, R. (1987), The Strange Liberalism of Alexis de Tocqueville, Ithaca and London: Cornell University Press.

Boettke, P. J. (Ed.) (1994), The Elgar Companion to Austrian Economics, Aldershot: Edward Elgar.

Bongie, L. L. (2000), David Hume. Prophet of the Counter-Revolution, Indianapolis: Liberty Fund.

Boucher, D. (1985), Texts in Context. Revisionist Methods for Studying the History of Ideas, Dordrecht: Martinus Nijhoff Publishers.

Boucher, D. (1991), 'The Character of the History of the Philosophy of International Relations and the Case of Edmund Burke', Review of International Studies, 17, 127-148.

Boucher, D. (1998), Political Theories of International Relations. From Thucydides to the Present, Oxford: Oxford University Press.

Bramsted, E. K. and Melhuish, K. J. (Ed.) (1978), Western Liberalism. A History in Documents from Locke to Groce, London and New York: Longman.

Brinton, C. (2000), A History of Western Morals, St. Paul: Paragon House.

Broadie, A. (2003), 'Introduction', in The Cambridge Companion to the Scottish Enlightenment (Ed. Broadie, A.), Cambridge:

Cambridge University Press, pp. 1-7.

Brown, C. (1992), '"Really Existing Liberalism” and International Order', Millennium: Journal of International Studies, 21, 313-328.

Brown, C. (2001), Understanding International Relations, Houndmills, Basingstoke: Palgrave.

Brown, C. (2002), Sovereignty, Rights and Justice. International Political Theory Today, Cambridge: Polity Press.

Brown, C., Nardin, T. and Rengger, N. J. (Ed.) (2002), International Relations in Political Thought. Texts from the Ancient Greeks to the First World War, Cambridge: Cambridge University Press. 
Buchan, J. (2006), Adam Smith and The Pursuit of Perfect Liberty, London: Profile Books.

Buchanan, J. (2005), Why, I, Too, Am Not a Conservative. The Normative

Vision of Classical Liberalism, Cheltenham and Northampton:

Edward Elgar.

Bull, H. (1966), 'Society and Anarchy in International Relations', in

Diplomatic Investigations. Essays in the Theory of International

Politics (Eds. Butterfield, H. and Wight, M.), London: George Allen

\& Unwin, pp. 35-50.

Bull, H. (1969), 'International Theory. The Case for the Classical

Approach', in Contending Approaches to International Politics

(Eds. Knorr, K. and Rosenau, J. N.), Princeton: Princeton

University Press, pp. 20-38.

Bull, H. (1994), 'Martin Wight and the Theory of International

Relations', in International Theory, The Three Traditions (Ed.

Wight, M.), London: Leicester University Press, pp. ix-xxiii.

Bull, H. (1995a), The Anarchical Society. A Study of Order in World

Politics, Houndmills and London: Macmillan.

Bull, H. (1995b), 'The Theory of International Politics 1919-1969',

in International Theory. Critical Investigations (Ed. Der Derian, J.),

Houndmills, Basingstoke and London: Macmillan Press,

pp. 181-211.

Bull, H. (2000), 'International Relations as an Academic Pursuit', in

Hedley Bull on International Society (Eds. Alderson, K. and Hurrel,

A.), Houndmills: Palgrave Macmillan, pp. 245-264.

Bull, H. and Watson, A. (Ed.) (1984), The Expansion of International

Society, Oxford: Clarendon Press.

Burchill, S. (2005), 'Liberalism', in Theories of International Relations

(Eds. Burchill, S., Linklater, A., Devetak, R., Donnelly, J., Paterson,

M., Reus-Smit, C. and True, J.), Houndmills and New York: Pal

grave, pp. 55-83.

Burchill, S. and Linklater, A. (2005), 'Introduction', in Theories of

International Relations (Eds. Burchill, S., Linklater, A., Devetak, R.,

Donnelly, J., Paterson, M., Reus-Smit, C. and True, J.), Houndmills and New York: Palgrave, pp. 1-28. 
Butler, E. (1985), Hayek. His Contribution to the Political and Economic Thought of Our Time, New York: Universe Books. Butler, E. (1988), Ludwig von Mises. Fountainhead of the Modern Microeconomics Revolution, Aldershot and Brookfield: Gower. Butterfield, H. (1950), Christianity and History, London: G. Bell and Sons.

Butterfield, H. (1966), 'The Balance of Power', in Diplomatic Investigations. Essays in the Theory of International Politics (Eds. Butterfield, H. and Wight, M.), London: George Allen \& Unwin, pp. 132-148.

Buzan, B. (2001), 'The English School: An Underexploited Resource in IR', Review of International Studies, 27, 471-488.

Buzan, B. (2004), From International to World Society? English School Theory and the Social Structure of Globalisation, Cambridge: Cambridge University Press.

Buzan, B. (2005), 'International Political Economy and Globalization', in International Society and its Critics (Ed. Bellamy, A. J.), Oxford: Oxford University Press, pp. 115-133.

Cairncross, A. (1976), 'The Market and the State', in The Market and the State. Essays in Honour of Adam Smith (Eds. Wilson, T. and Skinner, A. S.), Oxford: Clarendon Press, pp. 113-134. Cairns, J. W. (2003), 'Legal Theory', in The Cambridge Companion to The Scottish Enlightenment (Ed. Broadie, A.), Cambridge: Cambridge University Press, pp. 222-242.

Caldwell, B. (2004), Hayek's Challenge. An Intellectual Biography of F.A. Hayek, Chicago and London: The University of Chicago Press. Caldwell, B. (2006), 'Hayek and the Austrian Tradition', in The Cambridge Companion to Hayek (Ed. Feser, E.), Cambridge: Cambridge University Press, pp. 13-33.

Caldwell, B. (2007), 'Introduction', in The Collected Works of F.A Hayek, Volume II, The Road to Serfdom. Texts and Documents. The Definitive Edition (Ed. Caldwell, B.), Chicago: The University of Chicago Press, pp. 1-33.

Callahan, G. (2004), Economics for Real People. An Introduction to the Austrian School, Auburn: Ludwig von Mises Institute. 
Campbell, T. D. and Ross, I. S. (1981), 'The Utilitarianism of Adam

Smith's Policy Advice', Journal of the History of Ideas, 42, 73-92.

Carpenter, T. G. (1998), 'Toward Strategic Independence', in The

Libertarian Reader. Classical and Contemporary Writings From

Lao-Tzu to Milton Friedman (Ed. Boaz, D.), New York: The Free

Press, pp. 336-341.

Carpenter, T. G. (2002), 'From Republic to Empire: The Constitution

and The Evolution of U.S. Foreign Policy', in Toward Liberty. The

Idea That Is Changing The World (Ed. Boaz, D.), Washington

D.C.: Cato Institute, pp. 245-253.

Carr, E. H. (1995), The Twenty Years' Crisis 1919-1939, London:

Papermac.

Chafuen, A. (2003), Faith and Liberty. The Economic Thought of the

Late Scholastics, Lanham: Lexington Books.

Chesson, F. W. (Ed.) (1903), The Political Writings of Richard Cobden, in two volumes, London: T. Fisher Unwin.

Clark, H. C. (Ed.) (2003), Commerce, Culture \& Liberty. Readings on Capitalism before Adam Smith, Indianapolis: Liberty Fund.

Clark, I. (1988), Waging War. A Philosophical Introduction, Oxford: Clarendon Press.

Clark, I. (1989), The Hierarchy of States. Reform and Resistance in the International Order, Cambridge: Cambridge University Press. Clark, I. (1996), 'Traditions of Thought and Classical Theories of International Relations', in Classical Theories of International Relations (Eds. Clark, I. and Neumann, I. B.), Houndmills, Basingstoke and London: Macmillan Press, pp. 1-19.

Clark, I. and Neumann, I. B. (1996), 'Conclusion', in Classical Theories of International Relations (Eds. Clark, I. and Neumann, I. B.), Houndmills Basingstoke and London: Macmillan Press, pp. 256262.

Clinton, D. (2003), Tocqueville, Lieber, and Bagehot. Liberalism Confronts the World, Houndmills, Basingstoke: Palgrave.

Cliteur, P. B. (2000), 'Spontaneous Order, Natural Law, and Legal Positivism in the Work of F.A. Hayek', in Hayek Revisited (Eds. Bouckaert, B. and Godart-van der Kroon, A.), Cheltenham and Northampton: Edward Elgar, pp. 14-31. 
Cliteur, P. B. (2005), Natuurrecht, Cultuurrecht, Conservatisme.

Grondslag van de Democratische Rechtsstaat, Leeuwarden:

Universitaire Pers Fryslân.

Coats, A. W. (1975), 'Adam Smith and the Mercantile System', in Essays on Adam Smith (Eds. Skinner, A. S. and Wilson, T.), Oxford:

Clarendon Press, pp. 218-236.

Cobden, R. (1978), 'International Arbitration', in Western Liberalism. A History in Documents from Locke to Groce (Eds. Bramsted, E. K. and Melhuish, K. J.), London and New York: Longman, pp. 374-378.

Cohen, M. (1984), 'Moral Skepticism and International Relations', Philosophy and Public Affairs, 13, 299-346.

Conniff, J. (1978), 'Hume on Political Parties: The Case for Hume as a Whig', Eighteenth Century Studies, 12, 150-173.

Conway, D. (1995), Classical Liberalism, The Unvanquished Ideal, Houndmills, Basingstoke: Macmillan Press Ltd.

Conway, D. (2004), In Defence of the Realm. The Place of Nations in Classical Liberalism, Aldershot: Ashgate.

Cornish, P. (2007), 'The Ethics of “Effects-based” Warfare: The Crowding Out of Jus In Bello?' in The Price of Peace. Just War in the Twentieth-First Century (Eds. Reed, C. and Ryall, D.), Cambridge: Cambridge University Press, pp. 179-200.

Coudenhove-Kalergi, R. (1944), Letter to Ludwig von Mises, Greenwood, May 2.

Covell, C. (1998), Kant and the Law of Peace. A Study in the Philosophy of International Law and International Relations, Houndmills, Basingstoke and London: Macmillan Press.

Cowling, M. (1990), Mill and Liberalism, Cambridge: Cambridge University Press.

Crisp, R. (1997), Mill on Utilitarianism, London: Routledge. Crombag, H. and Van Dun, F. (1997), De Utopische Verleiding, Amsterdam: Contact.

Cubeddu, R. (1993), The Philosophy of the Austrian School, London: Routledge.

Cubitt, C. E. (2006), A Life of Friedrich August von Hayek, Gamlingay: Authors Online. 
Curzon Price, V. (1996), 'What do Liberals Have to Say About the Future of International and Inter-Ethnic Relations?' in Libertarians and Liberalism. Essays in Honour of Gerard Radnitzky (Ed. Bouillon, H.), Aldershot: Ashgate, pp. 298-318.

Cutler, C. A. (1991), 'The "Grotian tradition" in International Relations', Review of International Studies, 17, 41-65.

Danford, J. D. (1990), 'Hume's History and the Parameters of Economic Development', in Liberty in Hume's History of England (Eds.

Capaldi, N. and Livingston, D. W.), Dordrecht: Kluwer Academic Publishers, pp. 155-194.

Dawson, W. H. (1926), Richard Cobden and Foreign Policy. A Critical Exposition, with Special Reference to Our Day and its Problems, London: George Allen \& Unwin.

De Jasay, A. (1991), Choice, Contract, Consent: a Restatement of Liberalism, London: The Institute of Economic Affairs.

De Jasay, A. (2003), Liberalism, Loose or Strict, Brussels: Centre for the New Europe.

De Tocqueville, A. (1994), Democracy in America, London: David Campbell Publishers.

Delgaudio, J. J. (1987), Refugee Economist in America: Ludwig von Mises and American Social and Political Thought 1940-1986, Phd-thesis University of California at Irvine, Irvine.

Der Derian, J. (1995), 'Introduction: Critical Investigations', in International Theory. Critical Investigations (Ed. Der Derian, J.), Houndmills, Basingstoke and London: Macmillan Press, pp. 1-11. Desai, M. (2006), 'Hayek and Marx', in The Cambridge Companion to Hayek (Ed. Feser, E.), Cambridge: Cambridge University Press, pp. 67-81.

Deudney, D. (2004), 'Publius Before Kant: Federal-Republican Security and Democratic Peace', European Journal of International Relations, $10,315-356$.

Dietze, G. (1976), 'Hayek and the Rule of Law', in Essays on Hayek (Ed. Machlup, F.), Hillsdale: Hillsdale College Press, pp. 107-146. Dinan, D. (1994), Ever Closer Union? An Introduction to the European Community, Houndmills and London: Macmillan. 
Donnelly, J. (1992), 'Twentieth-century Realism', in Traditions of International Ethics (Eds. Nardin, T. and Mapel, D. R.), Cambridge: Cambridge University Press, pp. 85-111.

Donnelly, J. (2005), 'Realism', in Theories of International Relations (Eds. Burchill, S., Linklater, A., Devetak, R., Donnelly, J., Paterson, M., Reus-Smit, C. and True, J.), Houndmills: Palgrave MacMillan, pp. 29-54.

Doyle, M. W. (1986), 'Liberalism and World Politics', American Political Science Review, 80, 1151-1169.

Doyle, M. W. (1996), 'Kant, Liberal Legacies and Foreign Affairs', in Debating the Democratic Peace (Eds. Brown, M. E., Lynn-Jones, S.

M. and Miller, S. E.), Cambridge: MIT Press, pp. 3-57.

Doyle, M. W. (1997), Ways of War and Peace. Realism, Liberalism and Socialism, New York and London: W.W. Norton \& Company. Dunleavy, P. and O'Leary, B. (1987), Theories of the State. The Politics of Liberal Democracy, Houndmills and London: Macmillan Press. Dunne, T. (1993), 'Mythology or Methodology? Traditions in International Theory', Review of International Studies, 19, 305-318.

Dunne, T. (1998), Inventing International Society. A History of the English School, Houndmills, Basingstoke and London: MacMillan Press.

Dunne, T. (2005), 'Liberalism', in The Globalization of World Politics. An Introduction to International Relations (Eds. Baylis, J. and Smith, S.), Oxford: Oxford University Press, pp. 185-201.

Dunne, T. (2007), 'The English School', in International Relations Theories. Discipline and Diversity (Eds. Dunne, T., Kurki, M. and Smith, S.), Oxford: Oxford University Press, pp. 127-147.

Dunne, T., Kurki, M. and Smith, S. (Ed.) (2007), International Relations Theories. Discipline and Diversity, Oxford: Oxford University Press. Easley, E. S. (2004), The War over Perpetual Peace. An Exploration into the History of a Foundational International Relations Text, New York and Houndmills: Palgrave Macmillan.

Ebeling, R. M. (1977), 'Interview with F.A. Hayek', Libertarian Review, September (Hoover Institution Archives. Hayek Papers, box 109, folder 14). 
Ebeling, R. M. (1995), 'World Peace, International Order, and Classical Liberalism: A Comment on Shtromas and Anderson', International Journal on World Peace, vii, 47-68.

Ebeling, R. M. (Ed.) (2000a), Human Action. A 50-Year Tribute, Hillsdale: Hillsdale College Press.

Ebeling, R. M. (2000b), 'Introduction', in Selected Writings of Ludwig von Mises, volume 3. The Political Economy of International Reform and Reconstruction (Ed. Ebeling, R. M.), Indianapolis: Liberty Press, pp. ix-xli.

Ebeling, R. M. (2002), 'Introduction', in Selected Writings of Ludwig von Mises, volume 2. Between the Two World Wars: Monetary Disorder, Interventionism, Socialism, and the Great Depression (Ed. Ebeling, R. M.), Indianapolis: Liberty Fund, pp. xiii-lii.

Ebeling, R. M. (2003a), Austrian Economics and the Political Economy of Freedom, Cheltenham and Northampton: Edward Elgar Publishing.

Ebeling, R. M. (2003b), 'Classical Liberalism in the Twenty-First Century: War and Peace', in Liberty, Security, and the War on Terrorism (Eds. Ebeling, R. M. and Hornberger, J. G.), Fairfax: The Future of Freedom Foundation, pp. 173-178.

Ebeling, R. M. (2007), 'The Euro versus Currency Competition', The Freeman, 57.

Ebeling, R. M. and Hornberger, J. G. (Ed.) (1996), The Failure of America's Foreign Wars, Fairfax: The Future of Freedom Foundation. Ebeling, R. M. and Hornberger, J. G. (Ed.) (2003), Libert, Security, and the War on Terrorism, Fairfax: The Future of Freedom Foundation.

Ebenstein, A. (2001), Friedrich Hayek. A Biography, New York and Houndmills: Palgrave.

Ebenstein, A. (2003), Hayek's Journey. The Mind of Friedrich Hayek, New York and Houndmills: Palgrave Macmillan.

Eland, I. (2002), 'Does U.S. Interventionism Overseas Breed Terrorism?' in Toward Liberty. The Idea That Is Changing The World (Ed. Boaz, D.), Washington, D.C.: Cato Institute, pp. 264-273.

Eland, I. (2004), The Empire Has No Clothes. U.S. Foreign Policy Exposed, Oakland: The Independent Institute. 
Elshtain, J. B. (Ed.) (1992a), Just War Theory, New York and London: New York University Press.

Elshtain, J. B. (1992b), 'New Preface', in Just War Theory (Ed. Elshtain, J. B.), New York and London: New York University Press, pp. xi-xv. Elshtain, J. B. (2003), Just War Against Terror. The Burden of American Power in A Violent World, New York: Basic Books.

Epstein, R. A. (2003), Skepticism and Freedom, A Modern Case for Classical Liberalism, Chicago and London: The University of Chicago Press.

Evensky, J. (1995), 'The Role of Law in Adam Smith's Moral Philosophy', in Adam Smith and the Philosophy of Law and Economics (Eds.

Malloy, R. P. and Evensky, J.), Dordrecht, Boston and London: Kluwer Academic Publishers, pp. 199-219.

Fagerstrom, D. I. (1954), 'Scottish Opinion and the American

Revolution', The William and Mary Quarterly, 11, 252-275.

Fasnacht, G. E. (1952), Acton's Political Philosophy. An Analysis, London: Hollis and Carter.

Feser, E. (2006), 'Introduction', in The Cambridge Companion to Hayek

(Ed. Feser, E.), Cambridge: Cambridge University Press, pp. 1-12.

Feser, E. (2007), Locke, Oxford: Oneworld.

Feulner, E. J. (1999), Intellectual Pilgrims. The Fiftieth Anniversary of the Mont Pelerin Society, Washington: Edwin J. Feulner.

Fidler, D. P. and Welsh, J. M. (Ed.) (1999), Empire and Community. Edmund Burke's Writings and Speeches on International Relations, Boulder and Oxford: Westview Press.

Fierke, K. M. (2007), 'Constructivism', in International Relations Theories. Discipline and Diversity (Eds. Dunne, T., Kurki, M. and Smith, S.), Oxford: Oxford University Press, pp. 166-184.

Fieser, J. (Ed.) (2005), Early Responses to Hume's Moral, Literary and Political Writings, Bristol: Thoemmes.

Fitzgibbons, A. (1995), Adam Smith's System of Liberty, Wealth and Virtue. The Moral and Political Foundations of the Wealth of Nations, Oxford: Clarendon Press.

Fleischacker, S. (1999), A Third Concept of Liberty. Judgment and Freedom in Kant and Adam Smith, Princeton: Princeton University Press. 
Fleischacker, S. (2004), On Adam Smith's Wealth of Nations. A Philosophical Companion, Princeton and Oxford: Princeton University Press.

Fleming, J. M. (1976), 'Mercantilism and Free Trade Today', in The Market and The State. Essays in Honour of Adam Smith (Eds. Wilson, T. and Skinner, A. S.), Oxford: Clarendon Press, pp. 164-185. Forbes, D. (1975), Hume's Philosophical Politics, Cambridge: Cambridge University Press.

Franceschet, A. (2002), Kant and Liberal Internationalism. Sovereignty, Justice and Global Reform, Houndmills and New York: Palgrave Macmillan.

Franceschet, A. (2006), 'One Powerful and Enlightened Nation': Kant and the Quest for a Global Rule of Law', in Classical Theory in International Relations (Ed. Jahn, B.), Cambridge: Cambridge University Press, pp. 74-95.

Freedman, L. (2005), 'The Age of Liberal Wars', Review of International Studies, 31, 93-108.

Friedman, M. (2002), Capitalism and Freedom, Chicago: The University of Chicago Press.

Fuller, T. (1987), 'Jeremy Bentham and James Mill', in History of Political Philosophy (Eds. Strauss, L. and Crospey, J.), Chicago: The University of Chicago Press, pp.

Galipeau, C. J. (1994), Isaiah Berlin's Liberalism, Oxford: Clarendon Press.

Gamble, A. (1996), Hayek. The Iron Cage of Liberty, Cambridge: Polity Press.

Gellner, E. (1983), Nations and Nationalism, Oxford: Blackwell Publishers.

Gellner, E. (1997), Nationalism, London: Weidenfeld \& Nicolson. Gillingham, J. (2003), European Integration, 1950-2003. Superstate or New Market Economy?, Cambridge: Cambridge University Press. Gillingham, J. (2006), Design for A New Europe, Cambridge: Cambridge University Press.

Gissurarson, H. H. (1985), 'The Only Truly Progressive Policy....' in Hayek's Serfdom Revisited (Ed. Barry, N. P.), St. Leonards:

The Centre for Independent Studies, pp. 3-18. 
Gissurarson, H. H. (1987), Hayek's Conservative Liberalism, New York and London: Garland Publishing.

Glossop, R. J. (1984), 'Hume and the Future of the Society of Nations', Hume Studies, X, 46-58.

Goldsmith, M. M. (1966), Hobbes's Science of Politics, New York and London: Columbia University Press.

Gonce, R. A. (1973), 'Natural Law and Ludwig von Mises' Praxeology and Economic Science', Southern Economic Journal, 39, 490-507.

Goodin, R. E. (1995), Utilitarianism as a Public Philosophy, Cambridge: Cambridge University Press.

Gordon, D. (1993), 'Ludwig von Mises and the Philosophy of History', in The Meaning of Ludwig von Mises. Contributions in Economics, Epistemology, Sociology, and Political Philosophy (Ed. Herbener, J. M.), Norwell and Dordrecht: Kluwer Acadmeic Publishers \& Praxeology Press of the Ludwig von Mises Institute, pp. 118-133.

Gordon, D. (1996), The Philosophical Origins of Austrian Economics, Auburn: The Ludwig von Mises Institute.

Grammp, W. D. (1960), The Manchester School of Economics, Stanford and London: Stanford University Press \& Oxford University Press.

Gray, J. (1982), 'F.A. Hayek and the Rebirth of Classical Liberalism', Literature of Liberty, 5, 19-67.

Gray, J. (1995), Liberalism, Buckingham: Open University Press. Gray, J. (1998), Hayek on Liberty, London and New York: Routledge. Gray, J. (2002), Hume on Liberty and the Market - a Twenty-First Century Perspective. The Hume Lecture 2002, Edinburgh: The David Hume Institute.

Greaves, P. L. (1990), Mises Made Easier. A Glossary for Ludwig von Mises' Human Action, Irvington: Free Market Books.

Grieco, J. M. (1993), 'Anarchy and the Limits of Cooperation: A Realist Critique of the Newest Liberal Institutionalism', in Neorealism and Neoliberalism. The Contemporary Debate (Ed. Baldwin, D. A.),

New York: Columbia University Press, pp. 116-140.

Griswold, C. L. (1999), Adam Smith and the Virtues of Enlightenment, Cambridge: Cambridge University Press.

Guibernau, M. (1996), Nationalisms. The Nation-State and Nationalism in the Twentieth Century, Cambridge: Polity Press. 
Guyer, P. (Ed.) (1992), The Cambridge Companion to Kant, Cambridge: Cambridge University Press.

Haakonssen, K. (1981), The Science of a Legislator. The Natural Jurisprudence of David Hume and Adam Smith, Cambridge: Cambridge University Press.

Haakonssen, K. (1985), 'Foreword', in Hayek's 'Serfdom' Revisited (Ed. Barry, N. P.), St. Leonards: The Centre for Independent Studies, pp. vii-ix.

Haakonssen, K. (1993), 'The Structure of Hume's Political Theory', in The Cambridge Companion to Hume (Ed. Norton, D. F.), Cambridge: Cambridge University Press, pp. 182-221. Haakonssen, K. (1994), 'Introduction', in David Hume. Political Essays (Ed. Haakonssen, K.), Cambridge: Cambridge University Press, pp. xi-xxx.

Haakonssen, K. (2003), 'Natural Jurisprudence and the Theory of Justice', in The Cambridge Companion to the Scottish Enlightenment (Ed. Broadie, A.), Cambridge: Cambridge University Press, pp. 205-221.

Haakonssen, K. (2006), 'Introduction. The Coherence of Smith's Thought', in The Cambridge Companion to Adam Smith (Ed.

Haakonssen, K.), Cambridge: Cambridge University Press, pp. 1-21. Haakonssen, K. and Winch, D. (2006), 'The Legacy of Adam Smith', in The Cambridge Companion to Adam Smith (Ed. Haakonssen, K.), Cambridge: Cambridge University Press, pp. 366-394.

Haas, E. B. (1953), 'The Balance of Power: Prescription, Concept or Propaganda', World Politics, 5, 442-477.

Hall, I. (2006a), 'Diplomacy, Anti-Diplomacy and International Society', in The Anarchical Society in a Globalized World (Eds. Little, R. and Williams, J.), Houndmills and New York: Palgrave Macmillan, pp. 141-161.

Hall, I. (2006b), The International Thought of Martin Wight, Houndmills and New York: Palgrave Macmillan.

Halliday, F. (1994), Rethinking International Relations, Houndmills and London: Macmillan Press. 
Hammarlund, P. A. (2005), Liberal Internationalism and the Decline of the State. The Thought of Richard Cobden, David Mitrany and Kenichi Ohmae, Houndmills and New York: Palgrave Macmillan.

Harper, F. A. (Ed.) (1971), Toward Liberty. Essays in honor of Ludwig von Mises on Occasion of his 90th Birthday, September 29, 1971, in two volumes, Menlo Park: Institute for Humane Studies.

Harrison, J. (1981), Hume's Theory of Justice, Oxford: Clarendon Press. Harrison, R. (2003), Hobbes, Locke, and Confusion's Masterpiece. An Examination of Seventeenth-Century Political Philosophy, Cambridge: Cambridge University Press.

Hartwell, R. M. (1995), A History of the Mont Pelerin Society, Indianapolis: Liberty Fund.

Harvey, D. (2005), A Brief History of Neoliberalism, Oxford: Oxford University Press.

Hayek, F. A. (1948), Individualism and Economic Order, Chicago and London: The University of Chicago Press.

Hayek, F. A. (1966), 'The Misconception of Human Rights as Positive Claims', Farmand, II, 32-35 (Hoover Institution Archives, Hayek Papers, box 108, folder 12).

Hayek, F. A. (1967), Studies in Philosophy, Politics and Economics, New York: Simon and Schuster.

Hayek, F. A. (1968), 'A Self-Generating Order for Society', in Towards World Community (Ed. Nef, J.), The Hague: Dr. W. Junk N.V., pp. 39-42.

Hayek, F. A. (1969), John Stuart Mill and Harriet Taylor. Their Friendship and Subsequent Marriage, London: Routledge \& Kegan Paul.

Hayek, F. A. (1976), The Sensory Order. An Inquiry into the Foundations of Theoretical Psychology, Chicago: The University of Chicago Press.

Hayek, F. A. (1977), 'Internationaler Rufmord. Eine persönliche Stellungnahme', Politische Studien, 42-43 (Hoover Institution Archives, Hayek Papers, box 109, folder 18).

Hayek, F. A. (1978a), 'Integrating Immigrants', The Times, March 9. Hayek, F. A. (1978b), Letter to Menachem Begin, 18 January (Hoover Institution Archives, Hayek Papers, box 11, folder 45).

Hayek, F. A. (1978c), 'Letter to the Editor', The Times, 27 July (Hoover Institution Archives, Hayek Papers, box 109, folder 24). 
Hayek, F. A. (1978d), New Studies in Philosophy, Politics, Economics and the History of Ideas, Chicago: The University of Chicago Press.

Hayek, F. A. (1978e), 'Origins of Racialism', The Times, March 1. Hayek, F. A. (1979), The Counter-Revolution of Science. Studies on the Abuse of Reason, Indianapolis: Liberty Fund.

Hayek, F. A. (1980), Letter to Menachem Begin, 2 May (Hoover Institution Archives, Hayek Papers, box 11, folder 45).

Hayek, F. A. (1981a), 'The Flaws of the Brandt Report', The Times, 9 January (Hoover Institution Archives, Hayek Papers, box 110, folder 3).

Hayek, F. A. (1981b), Letter to Moshe Dayan, 11 October (Hoover Institution Archives, Hayek Papers, box 16, folder 59).

Hayek, F. A. (1981c), Letter to President Reagan, Freiburg, 11 February (Hoover Institution Archives, Hayek papers, box 45, folder 15).

Hayek, F. A. (1982a), Letter to Teddy Kolek, undated, most likely June or July (Hoover Institution Archives, Hayek Papers, box 31, folder 16). Hayek, F. A. (1982b), 'Schärfster Protest', Frankfurter Allgemeine Zeitung, 6 January.

Hayek, F. A. (1985), Letter to the editor of The Times, 21 April (Hoover Institution Archives, Hayek Papers, box 111, folder 13).

Hayek, F. A. (1990), Denationalisation of Money - The Argument Refined. An Analysis of the Theory and Practice of Concurrent Currencies, London: Institute of Economic Affairs.

Hayek, F. A. (1991), The Fatal Conceit. The Errors of Socialism., Chicago: The University of Chicago Press.

Hayek, F. A. (1992), The Fortunes of Liberalism. Essays on Austrian Economics and the Ideal of Freedom. The Collected Work of F.A. Hayek, volume IV, edited by Peter G. Klein, Chicago:

The University of Chicago Press.

Hayek, F. A. (1993), The Constitution of Liberty, London: Routledge. Hayek, F. A. (1994), Hayek on Hayek. An Autobiographical Dialogue. Edited by Stephen Kresge and Leif Wenar, Chicago: The University of Chicago Press.

Hayek, F. A. (1997a), The Road to Serfdom, London: Routledge. 
Hayek, F. A. (1997b), Socialism and War. Essays, Documents, Reviews. The Collected Works of F.A. Hayek, volume X, edited by Bruce Caldwell, Chicago: The University of Chicago Press.

Hayek, F. A. (1998), Law, Legislation and Liberty. A New Statement of the Liberal Principles of Justice and Political Economy, London: Routledge.

Hayek, F. A. (1999), Good Money, Part II, The Standard. The Collected Works of F.A. Hayek, volume VI, edited by Stephen Kresge, Chicago: The University of Chicago Press.

Hayek, F. A. (undated), An International Newspaper Page, Vienna, Undated (Hoover Institution Archives. Hayek Papers, box 104, folder 28).

Hayman, J. G. (1971), 'Notions on National Characters in the Eighteenth Century', Huntington Library Quarterly, 35, 1-17. Hennecke, H. J. (2000), Friedrich August von Hayek. Die Tradition der Freiheit, Düsseldorf: Verlag Wirtschaft und Finanzen, Verlagsguppe Handelsblatt GmbH.

Herbener, J. M. (1999), Mises on War and Peace in Human Action, www.mises.org, accessed: 23 December 2006.

Higgs, R. (2004), Against Leviathan. Government Power and A Free Society, Oakland: The Independent Institute.

Higgs, R. (2005), Resurgence of the Warfare State. The Crisis Since 9/11, Oakland: The Independent Institute.

Higgs, R. (2006), Depression, War, and Cold War. Studies in Political Economy, Oxford: Oxford University Press.

Hill, C. (1989), '1939: The Origins of Liberal Realism', Review of International Studies, 15, 319-328.

Hill, C. (2003), The Changing Politics of Foreign Policy, Houndmills, Basingstoke and New York: Palgrave Macmillan.

Hill, R. (2000), Lord Acton, New Haven and London: Yale University Press.

Himmelfarb, G. (1952), Lord Acton. A Study in Conscience and Politics, London: Routledge \& Kegan Paul.

Himmelfarb, G. (1974), On Liberty and Liberalism. The Case of John Stuart Mill, New York: Alfred A. Knopf. 
Hinsley, F. H. (1963), Power and the Pursuit of Peace, Cambridge: Cambridge University Press.

Hirst, F. W. (Ed.) (1968), Free Trade and Other Fundamental Doctrines of the Manchester School, New York: Augustus M. Kelley Publishers. Holbraad, C. (2003), Internationalism and Nationalism in European Political Thought, Houndmills and New York: Palgrave Macmillan. Holden, G. (2002), 'Who Contextualizes the Contextualizers?

Disciplinary History and the Discourse about IR Discourse', Review of International Studies, 28, 253-270.

Hollis, M. (1988), 'Say It With Flowers', in Meaning and Context.

Quentin Skinner and his Critics (Ed. Tully, J.), Cambridge: Polity Press, pp. 135-146.

Hollis, M. and Smith, S. (1990), Explaining and Understanding International Relations, Oxford: Clarendon Press.

Hoogensen, G. (2005), International Relations, Security and Jeremy Bentham, London and New York: Routledge.

Howard, M. (1992), 'Temperamenta Belli: Can War be Controlled?' in Just War Theory (Ed. Elshtain, J. B.), New York and London: New York University Press, pp. 23-35.

Howard, M. (2004), War and the Liberal Conscience, New Brunswick: Rutgers University Press.

Hoy, C. M. (1984), A Philosophy of Individual Freedom. The Political Thought of F.A. Hayek, Westport and London: Greenwood Press.

Hülsmann, J. G. (2007), Mises. The Last Knight of Liberalism, Auburn: Ludwig von Mises Institute.

Hume, D. (1932), The Letters of David Hume, in two volumes (Ed. J.Y.T. Greig), Oxford: Clarendon Press.

Hume, D. (1954), New Letters of David Hume (Eds. R. Klibansky and E.C. Mossner), Oxford: Clarendon Press.

Hume, D. (1983), The History of England. From the Invasion of Julius Caesar to The Revolution in 1688. In six volumes (Ed. William B. Todd), Indianapolis: Liberty Fund.

Hume, D. (1987), Essays. Moral, Political, and Literary (Ed. Eugene F. Miller), Indianapolis: Liberty Fund. 
Hume, D. (1993), Principal Writings on Religion, including Dialogues Concerning Natural Religion and The Natural History of Religion (Ed. J.C.A. Gaskin), Oxford: Oxford University Press.

Hume, D. (1998), An Enquiry concerning the Principles of Morals (Ed. Tom L. Beauchamp), Oxford: Oxford University Press.

Hume, D. (1999), An Enquiry concerning Human Understanding (Ed. Tom L. Beauchamp), Oxford: Oxford University Press.

Hume, D. (2000), A Treatise of Human Nature (Eds. David Fate Norton and Mary J. Norton), Oxford: Oxford University Press.

Hurrell, A. (1990), 'Kant and the Kantian Paradigm in International Relations', Review of International Studies, 16, 183-205.

Hurrell, A. (2001), 'Keeping History, Law, and Political Philosophy Firmly Within the English School', Review of International Studies, 27, 489-494.

Hurrell, A. (2002), 'Society and Anarchy in International Relations', in International Society and the Development of International Relations Theory (Ed. Roberson, B. A.), London and New York: Continuum, pp. 17-42.

Ikenberry, G. J. (2006), Liberal Order and Imperial Ambition. Essays on American Power and World Politics, Cambridge: Polity Press.

Ikenberry, G. J. and Kupchan, C. A. (2004), 'Liberal Realism. The

Foundations of a Democratic Foreign Policy', The National Interest, Fall, 38-49.

Infantino, L. (1998), Individualism in Modern Thought. From Adam Smith to Hayek, London and New York: Routledge.

Irwin, D. A. (1996), Against the Tide. An Intellectual History of Free Trade, Princeton: Princeton University Press.

Jackson, R. H. (1996), 'Is there a classical international theory?' in International Theory: positivism and beyond (Eds. Smith, S., Booth, K. and Zalewski, M.), Cambridge: Cambridge University Press, pp. 203-218.

Jackson, R. H. (2000), The Global Covenant. Human Conduct in a World of States, Oxford: Oxford University Press.

Jackson, R. H. (2005), Classical and Modern Thought on International Relations. From Anarchy to Cosmopolis, Houndmills and New York: Palgrave Macmillan. 
Jackson, R. H. (2007a), 'Sovereignty and its Presuppositions: Before 9/11 and After', Political Studies, 55, 297-317.

Jackson, R. H. (2007b), Sovereignty. Evolution of an Idea, Cambridge: Polity Press.

Jackson, R. H. and Sørensen, G. (2003), Introduction to International Relations. Theories and Approaches, Oxford: Oxford University Press.

Jahn, B. (2006a), 'Classical Smoke, Classical Mirror: Kant and Mill in Liberal International Relations Theory', in Classical Theory in International Relations (Ed. Jahn, B.), Cambridge: Cambridge University Press, pp. 178-203.

Jahn, B. (2006b), 'Classical Theory and International Relations in Context', in Classical Theory in International Relations (Ed. Jahn, B.), Cambridge: Cambridge University Press, pp. 1-24.

Jeffery, R. (2005), 'Tradition as Invention: The "Traditions Tradition" and the History of Ideas in International Relations', Millennium: Journal of International Studies, 34, 57-84.

Jeffery, R. (2006), Hugo Grotius in International Thought, New York and Houndmills: Palgrave Macmillan.

Jennings, I. W. (1940), A Federation for Western Europe, Cambridge: Cambridge University Press.

Jervis, R. (1992), 'A Political Science Perspective on the Balance of Power and the Concert', The American Historical Review, 97, 716-724.

Kant, I. (1991), 'Perpetual Peace. A Philosophical Sketch', in Kant.

Political Writings (Ed. Reiss, H.), Cambridge: Cambridge

University Press, pp. 93-130.

Kauppi, M. V. and Viotti, P. R. (1992), The Global Philosophers. World

Politics in Western Thought, New York and Toronto: Lexington Books.

Keane, J. (1988), 'More Theses on the Philosophy of History', in Meaning and Context. Quentin Skinner and his Critics (Ed. Tully, J.), Cambridge: Polity Press, pp. 204-217.

Kedourie, E. (1993), Nationalism, Oxford: Blackwell Publishers.

Keene, E. (2005), International Political Thought. A Historical Introduction, Cambridge: Polity Press. 
Keene, E. (2006), 'Images of Grotius', in Classical Theory in International Relations (Ed. Jahn, B.), Cambridge: Cambridge University Press, pp. 233-252.

Kelly, P. (2005), Liberalism, Cambridge: Polity Press.

Keohane, R. O. (1989), After Hegemony. Cooperation and Discord in the World Political Economy, Princeton: Princeton University Press.

Keohane, R. O. (1990), 'International Liberalism Reconsidered', in The Economic Limits to Modern Politics (Ed. Dunn, J.), Cambridge: Cambridge University Press, pp. 165-194.

Keohane, R. O. and Nye, J. N. (1989), Power and Interdependence, Cambridge, MA: HarperCollins.

Kersting, W. (1992), 'Politics, Freedom, and Order: Kant's Political Philosophy', in The Cambridge Companion to Kant (Ed. Guyer, P.), Cambridge: Cambridge University Press, pp. 342-366.

King, J. T. (1990), 'The Virtue of Political Skepticism', Reason Papers, 15, 24-46.

Kingsbury, B. and Roberts, A. (1990), 'Introduction: Grotian Thought in International Relations', in Hugo Grotius and International Relations (Eds. Bull, H., Kingsbury, B. and Roberts, A.), Oxford: Clarendon Press, pp. 1-64.

Kinneging, A. M. M. (1988), Liberalisme. Een Speurtocht naar de Grondslagen, Den Haag: Prof.Mr. B.M. Teldersstichting.

Kirchner, E. J. (1988), 'Introduction', in Liberal Parties in Western Europe (Ed. Kirchner, E. J.), Cambridge: Cambridge University Press, pp. 1-15.

Kirzner, I. M. (Ed.) (1982), Method, Process, and Austrian Economics. Essays in Honor of Ludwig von Mises, Lexington and Toronto: Lexington Books.

Kirzner, I. M. (1992), The Meaning of Market Process. Essays in the Development of Modern Austrian Economics, London: Routledge. Kirzner, I. M. (2001), Ludwig von Mises. The Man and his Economics, Wilmington: ISI Books.

Klibansky, R. and Mossner, E. C. (1954), 'Introduction', in New Letters of David Hume (Eds. Klibansky, R. and Mossner, E.C.) Oxford: Oxford University Press, pp. xiii-xxx. 
Knowles, D. (2001), Political Philosophy, London: Routledge.

Knutsen, T. L. (1997), A History of International Relations Theory, Manchester and New York: Manchester University Press.

Koch, K., Soetendorp, R. B. and Van Staden, A. (1994), Internationale Betrekkingen. Theorieën en Benaderingen, Utrecht: Aula / Het Spectrum.

Kotterman-van de Vosse, I. (1994), De Visie van Hayek. Een Pleidooi voor Persoonlijke Vrijheid, Zwolle: W.E.J. Tjeenk Willink.

Kukathas, C. (1989), Hayek and Modern Liberalism, Oxford: Clarendon Press.

Kukathas, C. (2006), 'Hayek and Liberalism', in The Cambridge Companion to Hayek (Ed. Feser, E.), Cambridge: Cambridge University Press, pp. 182-207.

Kurki, M. and Wight, C. (2007), 'International Relations and Social Science', in International Relations Theories. Discipline and Diversity (Eds. Dunne, T., Kurki, M. and Smith, S.), Oxford: Oxford University Press, pp. 13-33.

Lal, D. (2002), The Poverty of 'Development Economics', London: Institute of Economic Affairs.

Lal, D. (2004), In Praise of Empires. Globalization and Order, Houndmills and New York: Palgrave Macmillan.

Lal, D. (2006), Reviving the Invisible Hand. The Case for Classical Liberalism in the Twenty-First Century, Princeton and Oxford: Princeton University Press.

Lamy, S. L. (2005), 'Contemporary Mainstream Approaches: Neo-Realism and Neo-Liberalism', in The Globalization of World Politics. An Introduction to International Relations (Eds. Baylis, J. and Smith, S.), Oxford: Oxford University Press, pp. 205-224.

Leeson, P. T. and Boettke, P. J. (2006), 'Was Mises Right?' Review of Social Economy, 64, 247-265.

Letwin, S. R. (1998), The Pursuit of Certainty. David Hume, Jeremy Bentham, John Stuart Mill, Beatrice Webb, Indianapolis: Liberty Fund. 
Letwin, W. (1988), 'Was Adam Smith a Liberal?' in Traditions of Liberalism. Essays on John Locke, Adam Smith and John Stuart Mill (Ed. Haakonssen, K.), St Leonards: The Centre for Independent Studies, pp. 63-80.

Leube, K. R. (1984), 'Friedrich August von Hayek: A Biographical Introduction', in The Essence of Hayek (Eds. Leube, K. R. and Nishiyama, C.), Stanford: Hoover Institution Press, pp. xvii-xxxvi. Lieberman, D. (2006), 'Adam Smith on Justice, Rights, and Law', in The Cambridge Companion to Adam Smith (Ed. Haakonssen, K.),

Cambridge: Cambridge University Press, pp. 214-245.

Linares, F. (1984), Das Politischen Denken von David Hume, Hildesheim: Georg Olms Verlag.

Linklater, A. (2005), 'The English School', in Theories of International Relations (Eds. Burchill, S., Linklater, A., Devetak, R., Donnelly, J., Paterson, M., Reus-Smit, C. and True, J.), Houndmills and New York: Palgrave Macmillan, pp. 84-109.

Linklater, A. and Suganami, H. (2006), The English School of International Relations. A Contemporary Reassessment, Cambridge: Cambridge University Press.

Little, R. (2002), 'International System, International Society and World Society: A Re-evaluation of the English School', in International Society and the Development of International Relations Theory (Ed. Roberson, B. A.), London and New York: Continuum, pp. 59-79. Little, R. (2006), 'The Balance of Power and Great Power Management', in The Anarchical Society in a Globalized World (Eds. Little, R. and Williams, J.), Houndmills and New York: Palgrave Macmillan, pp. 97-120.

Lively, J. (1962), The Social and Political Thought of Alexis de Tocqueville, Oxford: Clarendon Press.

Lockwood, W. W. (1964), 'Adam Smith and Asia', The Journal of Asian Studies, 23, 345-355.

Lomasky, L. E. (2007), 'Liberalism Beyond Borders', Social Philosophy \& Policy, 24, 206-233.

Long, D. (1995), 'Conclusion: Inter-War Idealism, Liberal International ism, and Contemporary International Theory', in Thinkers of the Twenty Years' Crisis. Inter-War Idealism Reassessed (Eds. Long, D. and Wilson, P.), Oxford: Clarendon Press, pp. 302-328. 
Long, D. (1996), Towards A New Liberal Internationalism. The International Theory of J.A. Hobson, Cambridge: Cambridge University Press.

Long, D. (2006), 'Adam Smith's Politics', in The Cambridge Companion to Adam Smith (Ed. Haakonssen, K.), Cambridge: Cambridge University Press, pp. 288-318.

Macfie, A. L. (1967), The Individual in Society. Papers on Adam Smith, London: George Allen \& Unwin.

Machan, T. R. (2003), The Liberty Option, Exeter: Imprint Academic. Machlup, F. (1969), 'Liberalism and the Choice of Freedoms', in Roads to Freedom. Essays in Honour of Friedrich A. von Hayek (Ed.

Streissler, E.), London: Routledge \& Kegan Paul, pp. 117-146.

Mackie, J. L. (1980), Hume's Moral Theory, London: Routledge \& Kegan Paul.

MacMillan, J. (1998), On Liberal Peace. Democracy, War and the International Order, London and New York: I.B. Tauris Publishers. MacMillan, J. (2004), 'Liberalism and the Democratic Peace', Review of International Studies, 30, 179-200.

MacMillan, J. (2006), 'Immanuel Kant and the Democratic Peace', in Classical Theory in International Relations (Ed. Jahn, B.), Cambridge: Cambridge University Press, pp. 52-73.

Magid, H. M. (1987), 'John Stuart Mill', in History of Political Philosophy (Eds. Strauss, L. and Crospey, J.), Chicago: The University of Chicago Press, pp.

Manent, P. (1995), An Intellectual History of Liberalism, Princeton:

Princeton University Press.

Manning, D. J. (1976), Liberalism, London: J.M. Dent \& Sons Ltd. Manzer, R. A. (1996), 'The Promise of Peace? Hume and Smith on the Effects of Commerce on War and Peace', Hume Studies, XXII, 369-382.

Manzer, R. A. (2001), 'A Science of Politics: Hume, The Federalist, and The Politics of Constitutional Attachment', American Journal of Political Science, 45, 508-518.

Margerum Harlen, C. (1999), 'A Reappraisal of Classical Economic Nationalism and Economic Liberalism', International Studies Quarterly, 43, 733-744. 
Martin, L. L. (2007), 'Neoliberalism', in International Relations Theories. Discipline and Diversity (Eds. Dunne, T., Kurki, M. and Smith, S.), Oxford: Oxford University Press, pp. 109-126.

Mayall, J. (1990), Nationalism and International Society, Cambridge: Cambridge University Press.

McDonald, P. J. (2004), 'Peace Through Trade or Free Trade?', Journal of Conflict Resolution, 48, 547-572.

McGee, R. W. (1989), 'The Economic Thought of David Hume', Hume Studies, xv, 185-205.

Merikoski, I. A. (1996), 'Introduction', in Well Temper'd Eloquence (Ed. Merikoski, I. A.), Edinburgh: The David Hume Institute, pp. 1-3.

Miller, D. (1981), Philosophy and Ideology in Hume's Political Thought, Oxford: Clarendon Press.

Miller, E. (1962), 'David Hume: Whig or Tory?' New Individualist Review, 1, 19-27.

Miller, J. D. B. (1995), 'Norman Angell and Rationality in International Relations', in Thinkers of the Twenty Years' Crisis. Inter-War Idealism Reassessed (Eds. Long, D. and Wilson, P.), Oxford:

Clarendon Press, pp. 100-121.

Minogue, K. (1963), The Liberal Mind, Indianapolis: Liberty Fund. Minogue, K. (1988), 'Theorising Liberalism and Liberalising Theory', in Traditions of Liberalism (Ed. Hakkonssen, K.), St. Leonards: The Centre for Independent Studies, pp. 185-198.

Mizuta, H. (2000), Adam Smith's Library: A Catalogue, Oxford: Clarendon Press.

Moravcsik, A. (1997), 'Taking Preferences Seriously: A Liberal Theory of International Politics', International Organization, 51, 513-553.

Morgenthau, H. J. (1948), Politics Among Nations. The Struggle for Power and Peace, New York: Alfred A. Knopf.

Morley, J. (1903), The Life of Richard Cobden, London: T. Fisher Unwin.

Moss, L. S. (Ed.) (1976), The Economics of Ludwig von Mises. Toward a Critical Appraisal, Kansas City: Sheed and Ward.

Mossner, E. C. (1980), The Life of David Hume, Oxford: Clarendon Press. 
Mousseau, M., Hegre, H. and Oneal, J. R. (2003), 'How the Wealth of Nations Conditions the Liberal Peace', European Journal of International Relations, 9, 277-314.

Muller, J. Z. (2002), The Mind and the Market. Capitalism in Modern European Thought, New York: Anchor Books.

Nardin, T. (1992), 'Ethical Traditions in International Affairs', in Traditions of International Ethics (Eds. Nardin, T. and Mapel, D.

R.), Cambridge: Cambridge University Press, pp. 1-22.

Neimanis, G. J. (1980), 'Militia vs. the Standing Army in the History of Economic Thought from Adam Smith to Friedrich Engels', Military Affairs, 44, 28-32.

Nicholls, A. J. (1994), Freedom with Responsibility. The Social Market Economy in Germany, 1918-1963, Oxford: The Clarendon Press. Nishiyama, C. (1984), 'Introduction', in The Essence of Hayek (Eds. Leube, K. R. and Nishiyama, C.), Stanford: Hoover Institution Press, pp. xxxvii-lxviii.

Northedge, F. S. and Grieve, M. J. (1971), A Hundred Years of International Relations, London: Gerald Duckworth \& Co.

Nussbaum, A. (1954), A Concise History of the Law of Nations, New York: The Macmillan Company.

Nye jr., J. N. (1988), 'Neorealism and Neoliberalism', World Politics, XL, 235-251.

Nye jr., J. N. (1990), 'The Changing Nature of World Power', Political Science Quarterly, 105, 177-192.

Oncken, A. (1877), Adam Smith und Immanuel Kant. Der Einklang und das Wechselverhältniss ihrer Lehren über Sitte, Staat und Wirtschaft, Leipzig: Verlag von Dunecker \& Humblot.

Oneal, J. R. and Russett, B. (1997), 'The Classical Liberals Were Right:

Democracy, Interdependence, and Conflict, 1950-1985', International Studies Quarterly, 41, 267-294.

Oneal, J. R., Russett, B. and Berbaum, M. L. (2003), 'Causes of Peace: Democracy, Interdependence, and International Organiizations, 1885-1992', International Studies Quarterly, 47, 371-393.

Otteson, J. R. (2002), Adam Smith's Marketplace of Life, Cambridge: Cambridge University Press. 
Owen, J. M. (1996), 'How Liberalism Produces Democratic Peace', in Debating the Democratic Peace (Eds. Brown, M. E., Lynn-Jones, S. M. and Miller, S. E.), Cambridge: MIT Press, pp. 116-154. Owen, J. M. (1997), Liberal Peace, Liberal War. American Politics and International Security, Ithaca and London: Cornell University Press.

Oz-Salzberger, F. (2003), 'The Political Theory of The Scottish Enlightenment', in The Cambridge Companion to The Scottish Enlightenment (Ed. Broadie, A.), Cambridge: Cambridge University Press, pp. 157-177.

Panke, D. and Risse, T. (2007), 'Liberalism', in International Relations Theories. Discipline and Diversity (Eds. Dunne, T., Kurki, M. and Smith, S.), Oxford: Oxford University Press, pp. 89-108. Paul, R. (2007), A Foreign Policy of Freedom. 'Peace, Commerce and Honest Friendship', Lake Jackson: The Foundation for Rational Economics and Education.

Peacock, A. and Willgerodt, H. (1989), 'Overall View of the German Liberal Movement', in German Neo-Liberals and the Social Market Economy (Eds. Peacock, A. and Willgerodt, H.), London: MacMillan for the Trade Policy Research Centre, pp. 1-15. Pinker, S. (2002), The Blank Slate. The Modern Denial of Human Nature, New York: Penguin Books.

Pitts, J. (2005), A Turn to Empire. The Rise Of Imperial Liberalism in Britain and France, Princeton and Oxford: Princeton University Press.

Pocock, J. G. A. (1985), Virtue, Commerce and History. Essays on Political Thought and History, Chiefly in the Eighteenth Century, Cambridge: Cambridge University Press.

Pocock, J. G. A. (1989), Politics, Language, and Time. Essays on Political Thought and History, Chicago and London: The University of Chicago Press.

Polanyi, K. (1957), The Great Transformation. The Political and Economic Origins of Our Time, Boston: Beacon Hill Press.

Porter, B. (1978), 'Patterns of Thought and Practice: Martin Wight's "International Theory", in The Reason of States. A Study in International Political Theory (Ed. Donelan, M.), London: George Allen \& Unwin, pp. 64-74. 
Powell, J. (2000), The Triumph of Liberty, New York: The Free Press. Rae, J. (1895), Life of Adam Smith, London and New York: Macmillan \& Co.

Raico, R. (1989), Classical Liberalism in the Twentieth Century, Fairfaix: The Institute for Humane Studies.

Raico, R. (1996), 'Mises on Fascism, Democracy and Other Questions', Journal of Libertarian Studies, 12, 1-27.

Rapaczynski, A. (1987), Nature and Politics. Liberalism in the Philosophies of Hobbes, Locke and Rousseau, Ithaca and London: Cornell University Press.

Raphael, D. D. (1975), 'The Impartial Spectator', in Essays on Adam Smith (Eds. Skinner, A. S. and Wilson, T.), Oxford: Clarendon Press, pp. 83-99.

Raphael, D. D. and Macfie, A. L. (1982), 'Introduction', in Adam Smith. The Theory of Moral Sentiments (Eds. Raphael, D. D. and Macfie,

A. L.), Indianapolis: Liberty Fund, pp. 1-52.

Rappard, W. E. (1994), 'On Reading von Mises', in On Freedom and Free Enterprise. Essays in Honor of Ludwig von Mises (Ed. Sennholz, M.), Irvington-on-Hudson: The Foundation for Economic Education, pp. 17-33.

Rashid, S. (1994), 'The Intellectual Standards of Adam Smith's Day', Journal of Libertarian Studies, 11, 107-116.

Rasmussen, D. B. and Den Uyl, D. J. (1997), Liberalism Defended, The Challenge of Post-Modernity, Cheltenham UK \& Northampton, US: Edward Elgar Publishing Limited.

Reed, C. and Ryall, D. (Ed.) (2007), The Price of Peace. Just War in the Twenty-First Century, Cambridge: Cambridge University Press.

Reiss, H. (1991), 'Introduction', in Kant. Political Writings (Ed. Reiss, H.), Cambridge: Cambridge University Press, pp. 1-40.

Rengger, N. J. (1988), 'Serpents and Doves in Classical International Theory', Millennium: Journal of International Studies, 17, 215-225. Rengger, N. J. (2000a), International Relations, Political Theory and the Problem of Order. Beyond International Relations Theory?, London: Routledge.

Rengger, N. J. (2000b), 'Political Theory and International Relations:

Promised Land or Exit from Eden?' International Affairs, 76, 755-770. 
Rengger, N. J. (2002), 'On the Just War Tradition in the Twenty-First Century', International Affairs, 78, 353-363.

Rengger, N. J. (2004), 'Just A War Against Terror? Jean Bethke Elshtain's Burden and American Power', International Affairs, 80, 107-116. Rengger, N. J. (2006), 'Seeing (Double) in the Darkness: The Moral Vision of The Anarchical Society', in The Anarchical Society in A Globalized World (Eds. Little, R. and Williams, J.), Houndmills and New York: Palgrave Macmillan, pp. 35-50.

Reus-Smit, C. (2005), 'The Constructivist Challenge after September

11', in International Society and Its Critics (Ed. Bellamy, A. J.),

Oxford: Oxford University Press, pp. 81-94.

Richardson, J. L. (1997), 'Contending Liberalisms: Past and Present', European Journal of International Relations, 3, 5-33.

Richardson, J. L. (2001), Contending Liberalisms in World Politics. Ideology \& Power, Boulder and London: Lynne Rienner Publishers. Ritter von Kuehnelt-Leddihn, E. (1999), The Cultural Background of Ludwig von Mises, Auburn: The Ludwig von Mises Institute.

Robbins, L. (1937), Economic Planning and International Order, London: MacMillan and Co.

Robbins, L. (1971), Money, Trade and International Relations, London and Basingstoke: The Macmillan Press.

Robbins, L. (2000), A History of Economic Thought. The LSE Lectures (edited by Steven G. Medema and Warren J. Samuels), Princeton and Oxford: Princeton University Press.

Roberson, B. A. (Ed.) (2002), International Society and the Development of International Relations Theory, London and New York:

Continuum.

Roche, G. (1971), Frederic Bastiat. A Man Alone, New Rochelle: Arlington House.

Roche, G. (1976), 'The Relevance of Friedrich A. Hayek', in Essays on Hayek (Ed. Machlup, F.), New York: New York University Press, pp. 1-12.

Rogers, J. E. T. (1873), Cobden and Modern Political Opinion, London: MacMillan and Co.

Roos, N. H. M. (1994), 'Hayek's Kantian Heritage and Natural Law', in Hayek, Co-ordination and Evolution. His Legacy in Philosophy, 
Politics, Economics and the History of Ideas (Eds. Birner, J. and Van Zijp, R.), London and New York: Routledge, pp. 287-307. Röpke, W. (1959), International Order and Economic Integration, Dordrecht: D. Reidel.

Rosen, S. P. (2005), War and Human Nature, Princeton and Oxford: Princeton University Press.

Ross, I. S. (1995), The Life of Adam Smith, Oxford: Clarendon Press. Rothbard, M. N. (1980a), The Essential Von Mises, Grove City: Libertarian Press.

Rothbard, M. N. (1980b), 'Ludwig von Mises and Natural law: a Comment on Professor Gonce', Journal of Libertarian Studies, IV, 289-297.

Rothbard, M. N. (1988), Ludwig von Mises: Scholar, Creator, Hero, Auburn: The Ludwig von Mises Institute.

Rothbard, M. N. (2002), The Ethics of Liberty, New York and London: New York University Press.

Rothbard, M. N. (2006a), Classical Economics. An Austrian Perspective on the History of Economic Thought, Volume II, Auburn: Ludwig von Mises Institute.

Rothbard, M. N. (2006b), Economic Thought before Adam Smith. An Austrian Perspective on the History of Economic Thought., Auburn: Ludwig von Mises Institute.

Rothschild, E. (2001), Economic Sentiments. Adam Smith, Condorcet and the Enlightenment, Cambridge, MA and London: Harvard University Press.

Rotwein, E. (Ed.) (1970), David Hume. Writings on Economics, Madison: The University of Wisconsin Press.

Ruggie, J. G. (2002), 'At Home Abroad, Abroad at Home: International Liberalization and Domestic Stability in the New World', in The Globalization of Liberalism (Eds. Hovden, E. and Keene, E.), Houndmills, Basingstoke and New York: Palgrave, pp. 99-122. Russell, D. (1969), Frederic Bastiat. Ideas and Influence, Irvington-onHudson: Foundation for Economic Education.

Ryan, A. (1987), 'Introduction', in John Stuart Mill and Jeremy Bentham. Utilitarianism and Other Essays (Ed. Ryan, A.), London: Penguin Books, pp. 
Ryan, A. (1996), 'Hobbes's Political Philosophy', in The Cambridge Companion to Hobbes (Ed. Sorell, T.), Cambridge: Cambridge University Press, pp. 208-245.

Sally, R. (1998), Classical Liberalism and International Economic Order.

Studies in Theory and Intellectual History, London: Routledge. Sally, R. (2003) Whither the WTO? A Progress Report on the Doha Round, Washington: Cato Institute.

Schlereth, T. J. (1977), The Cosmopolitan Ideal in Enlightenment Thought. Its Form and Function in the Ideas of Franklin, Hume and Voltaire, 1694-1790, Notre Dame and London: The University of Notre Dame Press.

Scruton, R. (2000), Kant, Rotterdam: Lemniscaat.

Sen, A. (1999), Development As Freedom, Oxford: Oxford University Press.

Sen, A. and Rothschild, E. (2006), 'Adam Smith's Economics', in The Cambridge Companion to Adam Smith (Ed. Haakonssen, K.), Cambridge: Cambridge University Press, pp. 319-365.

Sennholz, M. (Ed.) (1994), On Freedom and Free Enterprise. Essays in Honor of Ludwig von Mises, Irvington-on-Hudson: The Foundation for Economic Education.

Shaver, R. (2006), 'Virtues, Utility, and Rules', in The Cambridge Companion to Adam Smith (Ed. Haakonssen, K.), Cambridge: Cambridge University Press, pp. 189-213.

Shearmur, J. (1996), Hayek and After. Hayekian Liberalism as a Research Programme, London and New York: Routledge.

Shearmur, J. (2006), 'Hayek's Politics', in The Cambridge Companion to Hayek (Ed. Feser, E.), Cambridge: Cambridge University Press, pp. $148-170$.

Shenfield, A. A. (1961), 'Law', in Agenda for a Free Society. Essays on Hayek's The Constitution of Liberty (Ed. Seldon, A.), London: Institute of Economic Affairs and Hutchinson \& Co, pp. 51-67. Sher, R. B. (1989), 'Adam Ferguson, Adam Smith and the Problem of National Defense', The Journal of Modern History, 61, 240-268.

Shilliam, R. (2006), "The "Other" in Classical Political Theory:

Re-contextualizing the Cosmopolitan/Communitarian Debate', in Classical Theory in International Relations (Ed. Jahn, B.), Cambridge: Cambridge University Press, pp. 207-232. 
Simmons, B. A. and Steinberg, R. H. (Ed.) (2006), International Law and International Relations, Cambridge: IO Foundation / Cambridge University Press.

Simon, J. L. (1996), The Ultimate Resource 2, Princeton: Princeton University Press.

Simons, H. C. (1944), 'Review of Ludwig von Mises, Omnipotent Government: The Rise of the Total State and Total War', The Annals of the American Academy of Political and Social Science, 26, 192-193.

Skidelsky, R. (2006), 'Hayek versus Keynes', in The Cambridge Companion to Hayek (Ed. Feser, E.), Cambridge: Cambridge University Press, pp. 82-110.

Skinner, A. S. (1979), A System of Social Science. Papers Relating to Adam Smith, Oxford: Clarendon Press.

Skinner, A. S. (1993), 'David Hume: Principles of Political Economy', in The Cambridge Companion to Hume (Ed. Norton, D. F.), Cambridge: Cambridge University Press, pp. 222-254.

Skinner, Q. (1998), Liberty Before Liberalism, Cambridge: Cambridge University Press.

Skinner, Q. (2002), Visions of Politics. Volume I: Regarding Method, Cambridge: Cambridge University Press.

Smith, A. (1981), An Inquiry into the Nature and the Causes of the Wealth of Nations (edited by R.H. Campbell and A.S. Skinner), in two volumes, Indianapolis: Liberty Fund.

Smith, A. (1982a), Lectures on Jurisprudence (edited by R.L. Meek, D.D. Rapahel and P.G. Stein), Indianapolis: Liberty Fund.

Smith, A. (1982b), The Theory of Moral Sentiments (edited by D.D. Raphael and A.L. Macfie), Indianapolis: Liberty Fund.

Smith, A. (1987), The Correspondence of Adam Smith (edited by E.C. Mossner and I. S. Ross), Indianapolis: Liberty Fund.

Smith, A. D. (1999), Myths and Memories of the Nation, Oxford: Oxford University Press.

Smith, C. (2006), Adam Smith's Political Philosophy. The Invisible Hand and Spontaneous Order, London and New York: Routledge.

Smith, M. J. (1992), 'Liberalism and International Reform', in Traditions of International Ethics (Eds. Nardin, T. and Mapel, D. R.), Cambridge: Cambridge University Press, pp. 201-224. 
Smith, S. (2007), 'Introduction: Diversity and Disciplinarity in International Relations Theory', in International Relations Theories. Discipline and Diversity (Eds. Dunne, T., Kurki, M. and Smith, S.), Oxford: Oxford University Press, pp. 1-12.

Sofka, J. R. (2001), 'The Eighteenth Century International System: Parity or Primacy?' Review of International Studies, 27, 147-163.

Sørensen, G. (2006), 'Liberalism of Restraint and Liberalism of Imposition: Liberal Values and World Order in the New Millennium', International Relations, 20, 251-272.

Soule, E. (2000), 'Hume on Economic Policy and Human Nature', Hume Studies, XXVI, 143-157.

Sowell, T. (1978), 'Adam Smith in Theory and Practice', in Adam Smith and the Wealth of Nations. 1776-1976 Bicentennial Essays (Ed. Glahe, F. R.), Boulder: Colorado Associated University Press, pp. 149-172.

Spall, R. F. (1985), Reform Ideas of the Anti-Corn Leaguers, Phd-thesis University of Illinois, Urbana-Champaign.

Spengler, J. J. (1978), 'Smith versus Hobbes: Economy versus Polity', in Adam Smith and the Wealth of Nations. 1776-1976 Bicentennial Essays (Ed. Glahe, F. R.), Boulder: Colorado Associated University Press, pp. 35-59.

Stanlis, P., J. (2003), Edmund Burke \& The Natural Law, New Brunswick and London: Transaction Publishers.

Steele, D. R. (1992), From Marx to Mises: Post-Capitalist Society and the Challenge of Economic Calculation, La Salle: Open Court.

Stevens, D. (1975), 'Adam Smith and the Colonial Disturbances', in Essays on Adam Smith (Eds. Skinner, A. S. and Wilson, T.), Oxford: Clarendon Press, pp. 202-217.

Stevens, D. (1987), 'Smith's Thoughts on the State of the Contest with America, February 1778', in Correspondence of Adam Smith (Eds. Mossner, E. C. and Ross, I. S.), Indianapolis: Liberty Fund, pp. 377-380.

Stewart, D. (1982), Account on the Life and Writings of Adam Smith, L.L.D., Indianapolis: Liberty Fund.

Stewart, J. B. (1963), The Moral and Political Philosophy of David Hume, New York and London: Columbia University Press. 
Stewart, J. B. (1992), Opinion and Reform in Hume's Political Philosophy,

Princeton: Princeton University Press.

Stout, M. (2007), European Commission Revealed? The European

Commission and the Enlargement, Phd-thesis Universiteit Maastricht, Maastricht.

Strauss, L. (1950), Natural Right and History, Chicago: The University of Chicago Press.

Stringham, E. P. (2004), 'Commerce, Markets, and Peace. Richard

Cobden's Enduring Lessons', The Independent Review, IX, 105-116.

Taylor, O. H. (1960), A History of Economic Thought, New York:

McGraw-Hill.

Teichgraeber, R. F. (1986), 'Free Trade' and Moral Philosophy. Rethinking

the Sources of Adam Smith's Wealth of Nations, Durham: Duke

University Press.

Ten, C. L. (1988), 'Mill's Defence of Liberty', in Traditions of Liberalism

(Ed. Haakonssen, K.), St Leonard's: The Centre for Independent

Studies Limited, pp. 144-168.

Thatcher, M. (1993), The Downing Street Years, London: Harper Collins Pubishers.

Thayer, B. A. (2004), Darwin and International Relations. On the

Evolutionary Origins of War and Ethnic Conflict, Lexington: The

University Press of Kentucky.

The Mont Pelerin Society (1974), Tribute to Mises, 1881-1973. The

Session of the Mont Pelerin Society at Brussels on 13th September

1974, Devoted to the Memory of Ludwig von Mises, Chislehurst:

Quadrangle Publications \& The Mont Pelerin Society.

Thomas, W. (1979), The Philosophical Radicals. Nine Studies in Theory and Practice 1817-1841, Oxford: Clarendon Press.

Tomlinson, J. (1990), Hayek and the Market, London and Winchester: Pluto Press.

Tooby, J. and Cosmides, L. (1992), 'The Psychological Foundations of Culture', in The Adapted Mind: Evolutionary Psychology and the Generation of Culture (Eds. Barkow, J., Cosmides, L. and Tooby, J.), New York: Oxford University Press, pp. 19-136.

Trebilcock, M. J. and Howse, R. (2005), The Regulation of International Trade, London and New York: Routledge. 
Tuck, R. (1996), 'Introduction', in Thomas Hobbes. Leviathan (Ed. Tuck, R.), Cambridge: Cambridge University Press, pp.

Tuck, R. (1999), The Rights of War and Peace. Political Thought and the

International Order. From Grotius to Kant, Oxford: Oxford University Press.

Tucker, J. A. and Rockwell, L. H. (1993), 'The Cultural Thought of Ludwig von Mises', in The Meaning of Ludwig von Mises. Contributions in Economics, Epistemology, Sociology, and Political Philosophy (Ed. Herbener, J. M.), Norwell and Dordrecht: Kluwer Academic Publishers \& Praxeology Press of the Ludwig von Mises Institute, pp. 284-320.

Van de Haar, E. R. (2008), 'David Hume and International Political Theory: A Reappraisal', Review of International Studies, 34. Van der Dennen, J. (1995), The Origin of War: The Evolution of a Male-coalitional Reproductive Strategy, Groningen: Origin Press.

Van Dun, F. (1994), 'Hayek and Natural Law. The Humean Connection', in Hayek, Co-ordination and Evolution. His Legacy in Philosophy, Politics, Economics and the History of Ideas (Eds. Birner, J. and Van Zijp, R.), London and New York: Routledge, pp. 269-286.

Van Dun, F. (2000), 'Human Dignity: Reason or Desire?' in Rationality, Information and Progress in Law and Psychology (Eds. Koppen, P. J. and Roos, N. H. M.), Maastricht: Maastricht University Press, pp.

Van Dun, F. (2001), 'Natural Law, Liberalism and Christianity', Journal of Libertarian Studies, xv, 1-36.

Van Dun, F. (2003), 'Natural law. A Logical Analysis', Etica \& Politica, V.

Van Dun, F. (2004), Political Liberalism and The Formal Rechtsstaat, http://allserv.rug.ac.be/ frvandun/RecentTexts.htm, accessed: 5 September 2007.

Van Dun, F. (2006), Concepts of Order, http://users.ugent.be/ frvandun/Texts/Articles/

ConceptsofOrder2006.pdf, accessed: 5 September 2007.

Vasquez, J. A. (1990), Classics of International Relations, Englewood Cliffs: Prentice Hall.

Vile, M. J. C. (1998), Constitutionalism and the Separation of Powers, Indianapolis: Liberty Fund.

Vincent, A. (1990), 'Classical Liberalism and Its Crisis Of Identity', 
History of Political Thought, XI, 143-161.

Vincent, R. J. (1981), 'The Hobbesian Tradition in Twentieth Century

International Thought', Millennium: Journal of International

Studies, 10, 91-101.

Vincent, R. J. (1984), 'Edmund Burke and the Theory of International

Relations', Review of International Studies, 10, 205-218.

Viner, J. (1930), 'English Theories of Foreign Trade Before Adam Smith',

The Journal of Political Economy, 38, 404-457.

Viotti, P. R. and Kauppi, M. V. (1987), International Relations Theory.

Realism, Pluralism, Globalism, New York: Macmillan.

Von Mises, L. (1916), 'Vom Ziel der Handelspolitik', Archiv für

Sozialwissenschaft und Sozialpolitik, 42, 561-585.

Von Mises, L. (1925), 'Die Theorien der Handelspolitik und die

Handelspolitische Krisis', Prager Breffe, 17 November.

Von Mises, L. (1926), 'Amerika und der Wiederaufbau der europäischen

Wirtschaft', Neue Freie Presse, 18 December.

Von Mises, L. (1932), 'Autarkie Bedeutet Untergang der Kultur!', Berliner Tageblatt, 31 March.

Von Mises, L. (1943), Letter to F.A. Hayek, New York City, July 18

(Hoover Institution Archives, Hayek Papers, box 38, folder 24).

Von Mises, L. (1978a), 'The Freedom to Move as an International

Problem', in The Clash of Group Interests and Other Essays (Ed.

Ebeling, R. M.), New York: The Center for Libertarian Studies, pp. 19-22.

Von Mises, L. (1978b), Notes and Recollections, Spring Mills: Libertarian Press.

Von Mises, L. (1980), Planning for Freedom and Sixteen Other Essays and Addresses, Grove City: Libertarian Press.

Von Mises, L. (1981a), Socialism. An Economic and Sociological Analysis, Indianapolis: Liberty Fund.

Von Mises, L. (1981b), The Theory of Money and Credit, Indianapolis: Liberty Fund.

Von Mises, L. (1983), Nation, State, and Economy. Contributions to the Politics and History of Our Time, New York and London: Institute for Humane Studies \& New York University Press.

Von Mises, L. (1984a), The Historical Setting of the Austrian School of 
Economics, Auburn: The Ludwig von Mises Institute of Auburn University.

Von Mises, L. (1985), Omnipotent Government. The Rise of the Total State and Total War, Grove City: Libertarian Press.

Von Mises, L. (1990a), Economic Calculation in the Socialist

Commonwealth, Auburn: The Ludwig von Mises Institute.

Von Mises, L. (1990b), Economic Freedom and Interventionism. An Anthology of Articles and Essays by Ludwig von Mises. Selected and edited by Bettina Bien Greaves, Irvington-on-Hudson: The Foundation for Economic Education.

Von Mises, L. (1990c), Money, Method, and the Market Process. Essays Selected by Margit von Mises, edited by Richard M. Ebeling, Nor well \& Dordrecht: Kluwer Academic Publishers \& Praxeology Press of the Ludwig von Mises Institute.

Von Mises, L. (1991), Two Essays by Ludwig von Mises. Liberty and Property and Middle-of-the-Road Policy Leads to Socialism, Auburn: The Ludwig von Mises Institute.

Von Mises, L. (1994), The Anti-Capitalistic Mentality, Grove City: Libertarian Press.

Von Mises, L. (1996a), Bureaucracy, Grove City: Libertarian Press.

Von Mises, L. (1996b), Critique of Interventionism, Irvington-onHudson: The Foundation for Economic Education.

Von Mises, L. (1996c), Human Action. A Treatise on Economics, San Francisco: Fox \& Wilkes.

Von Mises, L. (1996d), Liberalism. The Classical Tradition, Irvington-onHudson: The Foundation for Economic Education.

Von Mises, L. (2000a), Economic Policy. Thoughts for Today and Tomorrow, Irvington-on-Hudson: Free Market Books.

Von Mises, L. (2000b), Selected Writings, volume 3. The Political Economy of International Reform and Reconstruction. Edited by Richard M. Ebeling, Indianapolis: Liberty Fund.

Von Mises, L. (2002a), Selected Writings, volume 2. Between the Two World Wars: Monetary Disorder, Interventionism, Socialism and the Great Depression. Edited by Richard M. Ebeling, Indianapolis: Liberty Fund.

Von Mises, L. (2002b), The Ultimate Foundation of Economic Science. 
An Essay on Method, Irvington-on-Hudson: Foundation for Economic Education.

Von Mises, L. (2003), Epistemological Problems of Economics, Auburn:

Ludwig von Mises Institute.

Von Mises, L. (2005), Theory and History. An Interpretation of Social and Economic Evolution, Indianapolis: Liberty Fund.

Von Mises, L. (2006a), The Causes of the Economic Crisis. And Other Essays Before and After the Great Depression. Edited by Percy L.

Greaves, Auburn: The Ludwig von Mises Institute.

Von Mises, L. (2006b), Marxism Unmasked: From Delusion to

Destruction, Irvington-on-Hudson: Foundation For Economic Education.

Von Mises, M. (1984b), My Years with Ludwig von Mises, Cedar Falls:

Center for Futures Education.

Vorländer, K. (1919), Kant und der Gedanke des Völkerbundes. Mit dem Anhange: Kant und Wilson, Leipzig: Verlag von Felix Meiner.

Wæver, O. (2002), 'Four Meanings of International Society: A

Transatlantic Dialogue', in International Society and the Development

of International Relations Theory (Ed. Roberson, B. A.), London and

New York: Continuum, pp. 80-144.

Walker, G. (1986), The Ethics of F.A. Hayek, Lanham and London:

University Press of America.

Walker, R. B. J. (1993), Inside/Outside: International Relations as Political Theory, Cambridge: Cambridge University Press.

Walter, A. W. (1996), 'Adam Smith and the Liberal Tradition in International Relations', in Classical Theories of International Relations (Eds. Clark, I. and Neumann, I. B.), Houndmills: Macmillan Press, pp. 142-172.

Waltz, K. N. (1954), Man, The State and War. A Theoretical Analysis, New York: Columbia University Press.

Waltz, K. N. (1986), 'Anarchic Orders and Balances of Power', in Neorealism and its Critics (Ed. Keohane, R. O.), New York:

Columbia University Press, pp. 98-130.

Walzer, M. (1992), Just and Unjust Wars. A Moral Argument with Historical Illustrations, New York: Basic Books.

Walzer, M. (2005), Arguing About War, New Haven and London: Yale 


\section{University Press.}

Watson, A. (1992), The Evolution of International Society. A Comparative Historical Analysis, London and New York: Routledge.

Werner, J. M. (1972), 'David Hume and America', Journal of the History of Ideas, 33, 439-456.

West, E. G. (1976), Adam Smith. The Man and His Works, Indianapolis: Liberty Fund.

West, E. G. (1996), Adam Smith into the Twenty-First Century, Cheltenham and Brookfield: Edward Elgar Publishing.

Wheeler, N. J. and Dunne, T. (2002), 'Hedley Bull and the Idea of a Universal Moral Community: Fictional, Primordial or Imagined?' in International Society and the Development of International Relations Theory (Ed. Roberson, B. A.), London and New York: Continuum, pp. 43-58.

Whelan, F. G. (1985), Order and Artifice in Hume's Political Philosophy, Princeton: Princeton University Press.

Whelan, F. G. (1995), 'Robertson, Hume and the Balance of Power', Hume Studies, XXI, 315-332.

Whelan, F. G. (2004), Hume and Machiavelli. Political Realism and Liberal Thought, Lanham: Lexington Books.

Wight, M. (1966), 'Why is There No international Theory', in Diplomatic Investigations. Essays in the Theory of International Politics (Eds. Butterfield, H. and Wight, M.), London: George Allen \& Urwin, pp. 17-34.

Wight, M. (1977), Systems of States (edited by Hedley Bull), Leicester: Leicester University Press.

Wight, M. (1991), International Theory. The Three Traditions (edited by Gabriele Wight and Brian Porter), London: Leicester University Press for the Royal Institute of International Affairs.

Wight, M. (1995), Power Politics (edited by Hedley Bull and Carsten Holbrad), London: Leicester University Press for the Royal Institute of International Affairs.

Wight, M. (2005), Four Seminal Thinkers in International Theory. Machiavelli, Grotius, Kant and Mazzini (edited by Gabriele Wight and Brian Porter), Oxford: Oxford University Press.

Willgerodt, H. and Peacock, A. (1989), 'German Liberalism and 
Economic Revival', in Germany's Social Market Economy: Origins and Evolution (Eds. Willgerodt, H. and Peacock, A.), London: Mac Millan for the Trade Policy Research Centre, pp. 1-14.

Williams, A. (2006a), Liberalism and War. The Victors and the Vanquished, London and New York: Routledge.

Williams, H. (1983), Kant's Political Philosophy, Oxford: Basil Blackwell. Williams, H. and Booth, K. (1996), 'Kant: Theorist beyond Limits', in

Classical Theories of International Relations (Eds. Clark, I. and Neumann, I. B.), Houndmills, Basingstoke: Macmillan Press, pp. 71-98.

Williams, J. (2005), 'Pluralism, Solidarism and the Emergence of World Society in English School Theory', International Relations, 19, 19-38.

Williams, M. C. (2006b), 'The Hobbesian Theory of International Relations: Three Traditions', in Classical Theory in International Relations (Ed. Jahn, B.), Cambridge: Cambridge University Press, pp. 253-276.

Wilson, W. (1918), 'Speech to Congress', www.lib.byu.edu/ -rdh/wwi/ 1918/14points.html, accessed: 18 June 2007.

Winch, D. (1978), Adam Smith's Politics. An Essay in Historiographic

Revision, Cambridge: Cambridge University Press.

Winch, D. (1996), Riches and Poverty. An Intellectual History of

Political Economy in Britain, 1750-1834, Cambridge: Cambridge

University Press.

Wolin, S. S. (2001), Tocqueville Between Two Worlds. The Making of a

Political and Theoretical Life, Princeton and Oxford: Princeton

University Press.

Yeager, L. B. (2000), 'The Moral Element in Mises' Human Action', in

Human Action. A 50-Year Tribute (Ed. Ebeling, R. M.), Hillsdale: Hillsdale College Press, pp. 235-260.

Yost, D. S. (1994), 'Political Philosophy and the Theory of International Relations', International Affairs, 70, 263-290.

Young, O. R. (1989), International Cooperation. Building Regimes for

Natural Resources and the Environment, Ithaca and London:

Cornell University Press.

Younkins, E. W. (2005), 'Misesian Praxeology as the Path to Progress', 
in Philosphers of Capitalism. Menger, Mises, Rand and Beyond (Ed. Younkins, E. W.), Lanham and Oxford: Lexington Books, pp. 49-79.

Zacher, M. W. and Matthew, R. A. (1995), 'Liberal International Theory: Common Threads, Divergent Strands', in Controversies in International Relations Theory. Realism and the Neoliberal Challenge (Ed. Kegley Jr, C. W.), New York: St. Martin’s Press, pp. 107-150. Zmirak, J. (2001), Wilhelm Röpke. Swiss Localist, Global Economist, Wilmington: ISI Books.

Zuckert, M. P. (2002), Launching Liberalism. On Lockean Political Philosophy, Lawrence: University Press of Kansas. 


\section{INDEX}

Abbyssinia, 124

Act of Union, 10, 66

Acton, Lord, 6, 163-165, 177

Africa, 87, 129-130, 165, 177

America see United States of America

Amnesty International, 154

Ancient Greece, 70, 142

Angell, Norman, 138-139, 148, 205

Anti-Corn Law League see Manchester

School

Aquinas, St. Thomas, 179

Arafat, Yasser, 150

Argentina, 148

Ashworth, Lucian, 163

Asia, 80, 87, 129-130, 177

Augustine, St., 179

Australia, 126

Austria, 10-12, 105-107, 112, 120, 143, 184

Austrian School, 36-37, 49

authoritarianism, 85

Bagehot, Walter, 101

balance of power, 10,11, 20, 70-71,

77, 89, 122-124, 135, 138, 149, 162,

164, 168, 171, 186, 189-190, 207

199, 203, 215, 219

Barry, Norman, 43-44

Bartley, William, 157

Bastiat, Frédéric, 101, 117, 131, 136-137

Bauer, Peter, 156, 193

Baumgarth, W., 114

Belgium, 112, 129, 184

Bentham, Jeremy, 50, 53-54, 55, 61, 81, 100, 107, 109, 131-132, 135, 137, 142, 199, 208, 213, 216

Bartelson, Jens, 26
BBC, 145

Begin, Menachem, 150

Berlin, Isaiah, 42-43

Bodin, Jean, 139

Böhm, F., 36

Böhm-Bawerk, E. von, 36, 105, 107

Bonnie, Prince Charlie (Charles

Edward Stuart), 11

Boucher, David, 8, 77

Bowring, John, 132

Brandt Report, 156-157

Bretton Woods system, 199

Britain see Great Britain

Bright, John, 35, 100, 135

Brown, Chris, 101, 198

Buccleugh, Duke of, 80

Buchanan, James, 7, 37, 39

Bull, Hedley, 13-24, 187, 195, 205

Burchill, Scott, 100

Burke, Edmund, 55, 164

Butterfield, Herbert, 13, 19

Buzan, Barry, 14-15

Calvin, John, 20

Canada, 10, 58-59, 99, 112, 126

Cantillon, Richard, 83

capitalism, 12, 63, 111, 129, 217

Carnegie, Andrew, 20

Carr, E.H., 17, 18, 100-101, 152,

167, 199

Carter, Jimmy, 148

Chicago School, 37

Chile, 154-155, 168

China, 136

Churchill, Winston, 148

Classical liberalism, 2-7, 28, 35-57,

$36,54,117,124,161,212-219$

and Hayek, 141-143 
and Hume, 59-64

and Mises, 105-111

and Smith, 80-85

as IR theory, 31, 171-211,

212-219

as tradition, 24-27

core elements of, 40-50

fringe classical liberals, 50-57

in IR, 12-13, 17, 32-33

Clausewitz, Carl von, 18

Club of Rome, 157

Cobden, Richard, 2,6, 35, 100, 101, 121, 131, 133-137, 164, 191, 196, 199, 205, 216

collectivism, 11, 84

colonies, 10, 72-74, 90, 96, 177

colonialism see imperialism

communism, 12, 20, 140

Comte, Auguste, 108

Congo, 129

consequentialism, 43-45

Constant, Benjamin, 35

constructivism,

as IR theory, 15-16,

in political theory, 85, 108

Coudenhove-Kalergi, Count, 126

Constantinople, 88

cosmopolitanism, 20, 79, 86-87, 210,

216

Cromwell, Oliver, 9

Cubitt, Charlotte, 148

currency, 159-160, 185

Curzon-Price, Victoria, 163

Czechoslovakia, 112

Danford, J., 72

Dayan, Moshe, 150

Declaration of Rights (French), 45

Denmark, 66, 112, 126

development aid, 2, 9, 129-131, 155-

158, 162, 171, 193-194

diplomacy, 68, 88-90, 95, 133, 186-
187, 199

Doyle, Michael, 100, 102, 197-198,

204-210

Dunleavy, Patrick, 27

Dunne, Tim, 13-15, 198

Dutch East India Company, 98

Dutch Republic, 9, 35, 70, 74

Easley, Eric, 163

Eastern (Democratic) Union, 122, 127-128

Ebeling, Richard, 104

Ebenstein, Alan, 56, 146, 163, 170

Edinburgh University, 69

empire see imperialism

Engel-Janosi, F., 115

Engels, Friedrich, 56

England, 9, 66, 70, 73, 113, 148

English School, 3, 12-24, 25-27, 31, 75, 78, 103, 131, 167-171, 173-174,

182, 183, 188, 191-196, 205, 207.

210, 214, 216-219

Enlightenment, 5, 20, 35, 52, 65, 107,

118,213

Scottish, 5,11, 35, 75, 82, 141-

142, 195, 218

Epstein, Richard, 48

Erasmus, 5, 35

Erhard, Ludwig, 36

Eucken, Walter, 36

Europe, 80, 90-91, 97-99, 112, 114, 122, 127-128, 139, 149, 164, 166,

178, 182, 201, 205, 215

EEC see European Union

European integration, 9, 125-126,

183-186, 196, 217-218

European Union (EU), 90-91, 150,

158, 160, 184-187, 203, 219

fabianism, 130

Falkland Islands, 71, 148, 180

fascism, 20 
federation, 2, 125, 144, 148-151, 162, $165,169,171,182-184,217-218$

Ferguson, Adam, 46, 94, 138

Fichte, J.G., 112

Fitzgibbons, A., 94

Fleischacker, Samuel, 102

Founding Fathers, 35, 55, 177, 205

France, 10, 58-59, 70, 71, 80, 86, 90, $97,99,112,113,126,145,148,165$, 184

Franceschet, A., 209

Franklin, Benjamin, 73, 99

Freedom, 42-43, 63-64, 81, 142-143, 212-213, 215

Free trade see trade

Friedman, Milton, 7, 39, 53, 140, 155

Galen Carpenter, Ted, 190

GATT, 158, 191

Gellner, Ernest, 28, 144

Geneva, 12, 80, 105

Gentili, Alberico, 22

Germany, 10, 12, 112-113, 119, 120, 127-128, 137, 144-146, 149

Gissurarson, Hannes, 160

government see state

Grammp, William, 134

Gray, John, 36

Great Britain, 14, 67, 70, 74, 86, 90,

97-99, 112, 126, 145

Greaves, Bettina Bien, 106

Green, T.H., 36, 53, 101

Greenleaf, W.H., 24

Grotius, Hugo, 17, 22, 29, 69, 88-89, 103, 109, 179-180, 207, 213

Grotian tradition, 16-18, 21-24, 76, 78-79, 91, 100-104, 137-139, 167-

$171,174-211,214,217-218$

Guibernau, Montserrat, 28

Haberler, Gottfried, 106

Hamilton, Alexander, 35, 73-74
Hammarlund, Per, 101

Hall, Ian, 20

Hayek, Friedrich, 2, 4-7, 11-12, 17,

24, 28, 29, 31, 36, 39, 104, 106, 115,

$127,140-171,212-219$

and IR theory, 162-171

and nation, 144-146, 175-176,

193

and political theory, 48, 53, 56, 141-143, 182

as classical liberal, 141-143, 173 ideas on international relations, 146-162, 176-177, 179, 180-

211

Hegre, H., 205

Hennecke, H., 170

Higgs, Robert, 181, 190

Hill, Christopher, 186

Himmelfarb, Gertrude, 7

Hirst, F.W., 135

Hobbes, Thomas, 18, 47, 50-52, 78, $102,167,213$

Hobbesian tradition see Realist tradition

Hobhouse, L.T., 36, 53

Hobson, J. A., 36

Holland, 62, 87, 97

Hoppe, H.H., 40, 172

Howard, Michael, 100, 197

Hülsmann, J.G., 106

human nature, 41, 59-61, 72, 80-85, 93, 101, 103, 107-108, 142, 161-162, 173-175, 207, 215

Humboldt, A. von, 53

Hume, David, 2, 4-7, 10-11, 17, 24, 28, 29, 31, 58-79, 80, 94, 105, 142, 212-219

and IR theory, 76-79, 100, 103, $131,139,163,170-171$ and nation, 64-67, 85, 113, 162, 175-176, 193 and political theory, 44, 52-53, 
$81,108,109,161,182$

as classical liberal, 59-64, 107,

173

ideas on international relations, 67-76, 91, 95, 96, 115, 121, 128, 146-147, 164, 177, 180-211

Hurrell, Andrew, 14, 21, 206

Hutcheson, Francis, 92

IMF, 194, 203

impartial spectator, 82,89

imperialism, 72-74, 97-99, 124, 128-

$131,135,145,155-158,164,167$,

$171,176-178,216,219$

India, 128, 165

individualism, 41-42, 81-85, 173-175, 212-213

institutions (international), 14-15, 21, 103-104

international commerce see trade

International Labour Office, 153, 188 international law, 23, 29, 68-69, 8889, 92, 121-122, 135, 151-155, 162, 166, 170-171, 188, 199, 207, 215 international (governmental) organization, 9, 138, 151-155, 169-171, 188-190, 199, 202-203

International Political Theory (IPT), 3 International Relations (IR) Theory, 8, 27, 29-33, 77-79, 100-104, 131-142,

162-171, 172-219

international society, 14-15, 67-70,

78-79, 86-91, 104, 124-127, 162, 215

International society tradition see

Grotian tradition

international system tradition see Realist tradition

interventionism, 123, 136, 164, 196,

219

Iran, 147-148, 154, 180

Ireland, 96, 99, 165
Israel, 154

Italy, 124, 127-128

Jackson, Robert, 13, 23, 137, 182,

198

Jacobites, 11

James, Allan, 13,15

Japan, 145, 178

Jasay, Anthony de, 39

Jay, John, 35

Jeffery, Renee, 26

Jennings, Ivor, 150

Jerusalem, 150-151, 182

Kames, Lord (Henry Home), 99

Kant, Immanuel, 5, 17, 20, 38, 50,

52-53, 100, 108, 142, 149, 168, 170, 199-200, 205-207, 208, 213, 216

Kantian tradition, 16-18, 19-20, 75,

78-79, 100-104, 137-139, 167-171,

174-211, 216-217

Kauppi, M., 198

Kennan, George, 18

Keohane, Robert, 202, 209

Keynes, John Maynard, 147

Kinneging, Andreas, 52

Kirzner, Israel, 106

Kissinger, Henry, 18

Knutsen, Torbjørn, 24, 103

Kollek, Teddy, 150-151

Lal, Deepak, 178

Lasalle, B.F., 56

Laski, Harold, 152

Latin America, 177

Law of Nations, 29, 68-70, 88-89, 92

law, positive, 47-48, 61, 83, 142

law, rule of, $47-48,82-83,187-188$, 213

League of Nations, 12, 124-128, 129, 138-139, 152, 188, 201

Lebanon, 154 
Leiden (University), 103

Lenin, V.I., 138

Letwin, Shirley, 94

Levellers, 5, 35

Liberal internationalism, 138, 199-

201

liberalism, 1-2, 29-33, 34-40, 124,

$134,146,208-211,212-219$

embedded, 203-204

in IR, 1-3, 21, 163, 172-211

invented, 208-211, 216

social, 40-50, 205

thinkers, 50-57

libertarianism, 40, 172

liberty see freedom

Libya, 148

Lilburne, John, 35

Lisbon Treaty, 185

Locke, John, 5, 35, 53, 142, 208

London School of Economics (LSE),

$17,140,145$

Machiavelli, Nicolo, 18, 71, 77-79,

113, 165, 208

Machlup, Fritz, 106

MacMillan, J., 205

Madison, James, 35, 74

Malthus, Thomas, 134

Manchester School, 35, 75, 107, 118,

131, 133-137, 163, 164, 191

Mandeville, Bernard, 5, 35, 81, 141

Marshall Plan, 126-127, 186

Marx, Karl, 56, 138

marxism, 20, 84, 101, 130

Matthew, R., 197, 209

Mayall, James, 14, 137

McDonald, P., 205

Menger, Carl, 36, 105, 107

mercantilism, 63, 74, 95-97, 190

migration, 121, 158-159, 196, 219

Mill, James, 50, 53-54, 55, 100, 101, 132
Mill, John Stuart, 38, 42, 50, 53, 5557, 61, 97, 100, 132, 145, 165, 176, 213, 216

Milton, John, 5

Mises, Ludwig von, 4-7, 11-12, 17 , 24, 28, 29, 31, 36, 104, 105-142, 140-141, 212-219

and IR theory, 131-142, 163, $167,170-171$

and nation, 112-115, 144, 175-

176, 193

and political theory, 53, 182

as classical liberal, 107-111, 173

ideas on international relations, 115-131, 146-147, 152, 156, $158,160,176-177,179$,

$181-211$

Mitrany, David, 168, 201

Monnet, Jean, 149

Montesquieu, C.L., 205

Mont Pelerin Society, 37, 127, 140, 144, 156, 193

Moravcsik, A., 209

Morgenstern, Oskar, 106

Morgenthau, Hans, 17, 18, 77-78, 137, 199

Mousseau, M., 205

Müller-Armack, A., 36

Nardin, Terry, 101

nation see nationalism

nationalism, 27-29, 64-67, 85-87,

$112-115,116,124,130,139,144-$ $146,159,162,164,166,171,175-$

176,216

national character, 66-67, 72, 86-87, 113, 144-145, 164, 166

national interest, 71,73

NATO, 147, 186

natural law, 5, 43-46, 61-63, 69-70,

80-81, 91, 109, 136, 142, 178-182,

$188,213,215,218$ 
natural rights see natural law nazism, 20, 105, 113, 119, 137

Nef, John, 169

Nehru, Jawaharlal, 20

Neimanis , G., 94

neoliberalism, 38-40, 202

neoliberal institutionalism, 201-203

Netherlands, The, 126, 150, 184

Neurath, Otto, 147

neutrality, 89, 119

New York City, 105-106, 168

New Zealand, 126

Niebuhr, Reinhold, 18

Norway, 112, 126

Nye, Joseph, 202

O’Leary, Brendan, 27

Oneal, John, 100, 205, 206

Order, spontaneous, 46-47, 64, 143,

189-194, 213

Ordo-liberalism, 36-37

Owen, John, 205

pacifism, 77, 114, 116, 118, 123, 131,

139, 208

Paine, Thomas, 206

Palmerston, Lord Henry, 135

Pan-Europe, 125-126

Panke, D., 100

patriotism, 85-86, 146

peace, liberal democratic, 204-207

Peace Society, 133, 135

Philosophical Radicals, 53

Physiocrats, 35

Pinker, Steven, 174

Pitt, William (the older), 10

Pitt, William (the younger), 99

Pitts, Jennifer, 97

pluralism, 23-24, 104, 193, 210, 218

Pocock, J.G.A., 73

Poker Club, The, 94

Poland, 155, 159
Polanyi, Karl, 100

political theory, 3

Popper, Karl, 154, 160

Porter, Brian, 13

Portugal, 98

Pownall, Governor, 99

praxeology, 107

Pufendorf, Samuel, 22, 69, 79, 103,

109, 207

Quakers, 133

Quesnay, Francois, 83

Raico, Ralph, 114, 128

rationalism, 17, 85, 108

Rawls, John, 40

Reagan, Ronald, 37, 140, 147, 154

realism, 16-19, 78-79, 163, 165

Realist tradition, 16-19, 75, 78-79,

100-104, 137-139, 167-171, 174-211

reason, 41,60

regimes, 202-203

Rengger, Nicholas, 16, 79, 101, 196

revolutionism, 10, 17, 20

Ricardo, David, 107, 109, 131-133

Richardson, James, 163, 209

rights

human, 49-50, 64, 80-81, 84, 153, 178-179, 188, 196

to property, 49, 69, 81

theorists of, 43-45

Risse, Thomas, 100

Robbins, Lionel, 148

Roche, George, 136

Rockwell, Lew, 109

Romania, 127

Romantics, 110

Röpke, Wilhelm, 36, 121

Roosevelt, Franklin D., 20

Rothbard, Murray, 40, 96, 106, 109, 110, 172

Rousseau, Jean Jacques, 5, 20, 45, 
110,213

Ruggie, John, 203-204

Russett, Bruce, 100, 206

Russia, 88, 122, 123, 127-128, 135-

136, 147, 156, 186

Rüstow, Alexander, 36

Ryswick (Rijswijk), peace of, 70

Sally, Razeen, 204

Say, Jean Baptiste, 35

Schmitt, Carl, 167

Scholastics (Spanish), 5, 35

Schumpeter, J., 205, 208

Scotland, 9-11, 90, 93-94

Sennholz, Hans, 106

Simon, Julian, 157-158

Skidelsky, R, 152

Skinner, Quentin, 8

slavery, 63-64, 97, 164

Smith, Adam, 2, 4-7, 10-11, 17, 24, 28, 29, 31, 80-104, 105, 134-135,

$142,164,206,212-219$

and economics, 35, 63, 83-84,

95-97, 132

and IR theory, 100-104, 131, $138-139,163,170-171$

and nation, 85-87, 113, 135,

$144,162,175-176,193$

and political theory, 44, 48, 53,

$87,108,109,160,182$

as classical liberal, 80-85, 107,

173

ideas on international relations, 75, 91-95, 85-99, 115, 121, 128, 146-147, 164, 179,

$181-211$

Smith, M.J., 100, 198

socialism, 12, 84, 130, 138, 140, 141, 145

solidarism, 23-24, 195-196, 218

Sørensen, G., 198

South Africa, 154-155, 168 sovereignty, 11, 65, 115, 137, 139,

164, 177, 201

Soviet Union see Russia

Spain, 10, 71, 97, 99

Spencer, Herbert, 36, 53

Spinoza, 5, 35

state, 27-28, 49-50, 64, 84, 110-111,

213,216

as international actor, 64-65, 67-

$71,179-183,215,216$

St. Clair, General, 58

Steuart, James, 83

Stewart, Dugald, 83

Stoics, 5, 35, 81, 86

Strauss, Franz Josef, 140

Streit, Clarence, 125-126, 148-149

Stuarts, 11

Suarez, Francesco de, 22, 29

Sumner, W.G., 36

Switzerland, 62, 112, 125

Syria, 154

Teichgraeber, Richard, 103

Thatcher, Margaret, 37, 140, 143,

155, 159

Thucydides, 18

Tocqueville, Alexis de, 6, 35, 55, 97, $163,165-167$

Tories, 11, 63, 73

totalitarianism, 11, 20, 141

Trade, 11, 72, 74-76, 83-84, 95-97, 117, 120-121, 158-160, 171, 203-204 and peace, 75, 91, 94-95, 118, $120-121,131,134-135,160-$ $162,166,190-193,199$, 205-207, 210-211

traditions, 16-27, 213

transnationalism, 202

Tucker, Jeffrey, 109

Turgot, A.R.J., 74, 83, 206 
United Nations, 124, 152, 155, 179 , 188, 199, 203

United States of America, 12, 59, 90, $105,112,123,124,125,127,136$, 146-148, 164, 177-178, 181, 186, 190

independence of, 72-74, 96-99, 164, 177, 179

utilitarianism, 43-45, 53-57, 61, 81, 109-110, 134, 142-143

utopianism, 37, 79, 97, 101, 102, $118,130,136,137,168,196,210$, 216

Utrecht, 10, 92, 103

Vaugh, Karen, 5

Van Dun, Frank, 44

Vattel, Emmerich de, 22, 207

Vienna, 11, 58, 105-107, 148, 159

Viotti, P.,198

Vincent, John, 13

Virginia School, 37

Vitoria, Francisco de, 22

Walter, Andrew, 80, 101-104, 214215

Waltz, Kenneth, 18, 197

Walzer, Michael, 77, 180 war, 9, 10, 20, 71-72, 91-95, 115-120, 136, 146-148, 164, 166, 167, 171, 185

Cold, 12, 122, 140, 186

Crimean, 135, 166

First World War, 11-12, 105, 115, 143-144, 167 just war, 22, 68-70, 71-72, 9195, 171, 179-181, 196

Second World War, 11-12, 35, 106, 117, 119, 120, 121, 122, $125,133,140,146,149,152$, 177, 199, 203

Watson, Adam, 13
Webb, Beatrice and Sydney, 145

Western Union, 122

Wheeler, Nicholas, 14-15

Whelan, Frederick, 77-79

Whigs, 11, 63, 71, 73, 164

Wieser, Friedrich von, 36, 141

Wight, Martin, 13-24, 25-27, 77, 153

William (King) and Mary (Queen), 9

Williams, Andrew, 210

Wilson, James, 135

Wilson, Peter, 163

Wilson, Woodrow, 20, 124, 138, 199-200

World Bank, 194, 203

world government, 124-125, 151-155,

165, 168-170, 196

world society tradition see Kantian

tradition

WTO, 191

Yost, D.S,. 25

Young, Oran, 163

Yugoslavia, 112, 184

Zacher, M.,197, 209 


\section{Het Klassieke Liberalisme en de Theorieën van Internationale Betrekkingen}

\section{Hume, Smith, Mises, Hayek en de Internationale Samenleving}

Het is niet overdreven om te claimen dat het liberalisme een van de belangrijkste stromingen is binnen de theoretische studie van de internationale betrekkingen (IB). Maar er is iets merkwaardigs aan de hand. De verschillende uitingen van het liberalisme in IB hebben allemaal dezelfde filosofische premissen en grofweg ook hetzelfde doel. Dat komt omdat het uitwerkingen betreft van de sociaalliberale variant, ofwel het liberalisme in de hedendaagse Amerikaanse betekenis. Dat is voornamelijk gebaseerd op het werk van Kant, Mill, Wilson en Rawls. Het gevolg is dat liberalisme in IB vaak gelijk gesteld wordt aan een utopisch geloof in wereldvrede, pleidooien voor een wereldregering of andere vormen van internationale gouvernementele organisatie of het idee dat er een natuurlijke harmonie van menselijke belangen bestaat.

Opvallend is dat een andere liberale hoofdstroming, het klassieke liberalisme, geen eigen plek heeft in IB. De op zichzelf al sporadische studie van het klassieke liberalisme lijkt bij de nationale grens te stoppen, of zich hoogstens te beperken tot de internationale economische betrekkingen. Dit is merkwaardig, want het gaat niet om een obscure variant. Tot het klassieke liberalisme behoren toonaangevende denkers, waaronder de belangrijkste representanten van de Schotse Verlichting David Hume en Adam Smith en prominente 20e eeuwse politiek economen zoals Ludwig von Mises en de Nobelprijswinnaars Friedrich Hayek, Milton Friedman en James Buchanan.

Ondanks de omvangrijke literatuur die over deze denkers is verschenen is het geheel onderbelicht gebleven dat zij ook over internationale betrekkingen schreven, met name over oorlog en vrede, internationaal recht, vrijhandel, de nationale staat in internationaal verband, de machtbalans, nationalisme, imperialisme, bovenstatelijke samenwerking en de latere denkers soms ook over ontwikkelingshulp. Tot nu toe is er nooit 
een grondige poging gedaan deze ideeën over IB te analyseren. Mogelijk is dit veroorzaakt door een gebrek aan belangstelling voor het klassieke liberalisme, of omdat deze ideeën vaak 'verborgen' zitten in losse zinnen, alinea's, paragrafen of korte hoofdstukken. Er is dus grondig onderzoek vereist om het klassiek liberale internationale denken op te delven, in het juiste verband te plaatsen en op hun theoretische en praktische merites te beoordelen. Maar gelet op de grote invloed die klassiek liberale denkers sinds de $18 \mathrm{e}$ eeuw hebben gehad op de wereldwijde politieke en economische ontwikkelingen, is het belangrijk om ook de internationale aspecten van hun denken boven water te krijgen. Die ideeën hebben ook invloed gehad op hun lezers, kunnen waardevol zijn voor het hedendaagse politieke debat en een nieuw licht werpen op de theorie van IB. Het gebrek aan kennis van het klassieke liberalisme onder IB-deskundigen heeft geresulteerd in een onvolledig, soms ronduit foutief, begrip van het internationale liberale perspectief. Dit proefschrift is een eerste poging tot correctie.

De casus van het klassieke liberalisme binnen IB is weliswaar uniek maar past in een breder verband. Als gevolg van academische specialisatie hebben de politieke filosofie en de theorie van IB de afgelopen eeuw een gescheiden ontwikkeling doorgemaakt. Politieke filosofen hebben de internationale politieke dimensie verwaarloosd, terwijl IB-theoretici zich vooral hebben beperkt tot het filosofische werk van een klein aantal 'usual suspects', zoals Thomas Hobbes en Immanuel Kant. Dat is jammer, want de materie van beide disciplines is nauw verwant en hun integratie draagt bij aan een betere kennis van nationale en internationale politieke processen. Een nevengevolg van de disciplinaire scheiding is dat er een tekort is aan goede overzichten van het internationale denken van de meeste vooraanstaande politieke denkers. In dit proefschrift wordt dit hiaat deels opgevuld voor wat betreft de liberale traditie. Het sluit daarmee aan bij het bredere onderzoeksveld met de enigszins ongelukkige - want multi-interpretabele - naam 'internationale politieke theorie', ofwel International Political Theory.

De introductie van de klassiek liberale visie op internationale betrekkingen in dit proefschrift verloopt via het beantwoorden van de vraag:

Hoe denken klassiek liberalen over internationale politiek en hoe verhouden hun ideeën zich tot het huidige liberalisme in de theorie van internationale betrekkingen? 
Deze centrale onderzoeksvraag omvat een aantal subvragen, te weten:

- Wat is het klassieke liberalisme?

- Wat schreven de belangrijkste klassiek liberalen over internationale politieke onderwerpen?

- Hoe worden deze klassiek liberalen gezien door IB theoretici?

- Bestaat een aparte klassiek liberale theorie ten aanzien van internationale betrekkingen en wat is daarvan de inhoud?

- Zo ja, hoe verhoudt deze theorie zich tot andere liberale theorieën van IB?

De antwoorden op deze vragen leiden tot de vergroting van de kennis van het liberalisme in het algemeen en van het klassieke liberalisme in het bijzonder. Daarbij wordt de kennis en positie van het liberalisme binnen de theorieën van internationale betrekkingen aangevuld en is het mogelijk om het klassieke liberalisme een eigen plek in IB te geven.

In de beantwoording staat het werk centraal van vier van de eerder genoemde denkers, Hume, Smith, Mises en Hayek. Hun gehele oeuvre wordt onderzocht op de ideeën over internationale betrekkingen. Voor Hume, Hayek en Mises is het de eerste volledige weergave van hun denken op dit vlak, terwijl van het internationaal-politiek denken van Smith een nieuwe interpretatie wordt gegeven. Voor dit viertal is gekozen omdat zij momenteel de meest invloedrijke vertegenwoordigers van de klassiek liberale stroming zijn, afgemeten aan hun reputatie, het aantal academische referenties, aantallen volgelingen, het in druk blijven van hun werk en naar hen genoemde denktanks, instituten en lezingen. In het proefschrift wordt aangetoond dat zij een hechte politiek-filosofische traditie vormen en wordt tevens beargumenteerd waarom zij geschikter zijn voor deze studie dan andere kandidaten, zoals Locke, Acton, Tocqueville, Buchanan of Friedman. Vanzelfsprekend heeft deze keus arbitraire kanten, maar het onderliggende idee is dat een studie naar de internationale kant van het klassieke liberalisme gebaseerd dient te zijn op haar belangrijkste vertegenwoordigers. Hedendaagse invloed heeft in deze voorrang boven chronologie, hoewel ook een aantal $19 \mathrm{e}$-eeuwse liberalen de revue passeert.

Het internationale politieke denken van de vier klassiek liberalen wordt geïnterpreteerd met behulp van de Engelse School, een theorie van 
internationale betrekkingen waaraan van oudsher onder andere Martin Wight, Hedley Bull en Herbert Butterfield verbonden zijn. De Engelse School heeft een overwegend historische benadering van de studie van IB en is deels ontstaan als tegenreactie op de Amerikaanse, positivistische benaderingen die in de jaren 1950 aan prominentie won in de sociale wetenschappen. De Engelse School onderscheidt in de ideeëngeschiedenis drie hoofdstromingen, tradities of perspectieven (de termen worden door elkaar gebruikt) om internationale politiek te ordenen en te verklaren. Ten eerste de realistische of Hobbesiaanse traditie, waarin de machtspolitiek en de overlevingsstrijd van de nationale staat centraal staat; ten tweede de revolutionaire of Kantiaanse traditie die een radicale omvorming van het internationale systeem voorstaat; en ten derde de tussenweg van het rationalisme of de Grotiaanse traditie, waarin de wereld wordt gezien als een internationale samenleving van nationale staten, met daarin Hobbesiaanse en Kantiaanse elementen. Dit proefschrift onderscheidt zich van de discussies over en binnen de Engelse School door deze tradities als analysekader te gebruiken en om te bepalen welke traditie dominant is in het denken van Hume, Smith, Mises en Hayek. Deze inzichten worden vervolgens vergeleken met de bestaande opvattingen die over (een aantal van) hen bestaat binnen IB. Vervolgens wordt er een aantal andere nieuwe theoretische bevindingen aan ontleend.

\section{Wat is klassiek liberalisme?}

Vaak gaan schrijvers over het liberalisme een definitie of zelfs een grove afbakening uit de weg, omdat dit onmogelijk zou zijn door de veelzijdigheid van opvattingen binnen de liberale traditie. Hoewel dergelijke moeilijkheden worden erkend, wordt hier toch een poging gedaan de betekenis van de term klassiek liberalisme te preciseren. Als immers iedere opvatting als liberaal kan worden aangeduid, heeft het liberalisme als politiek-filosofische traditie geen onderscheidende betekenis.

$\mathrm{Na}$ een korte historische verkenning, wordt het klassieke liberalisme gepositioneerd als één van de drie liberale hoofdstromingen, naast het sociaal liberalisme en het libertarisme. De kernelementen van het klassieke liberalisme zijn (methodologisch) individualisme, het belang van de indi- 
viduele (negatieve) vrijheid, geloof in een niet-metafysische natuurrecht, vertrouwen in de spontane ordening van maatschappelijke processen en de omarming van de rechtsstaat, waarbij de staat een minimaal takenpakket heeft.

Deze afbakening betekent dat sommige denkers buiten de klassiek liberale traditie vallen, terwijl zij in de literatuur vaak wel tot deze traditie worden gerekend. Aangetoond wordt echter dat Hobbes, Kant, Bentham en de utilitaristen, alsmede John Stuart Mill wel liberaal maar niet klassiek liberaal te noemen zijn, omdat in hun werk meestal maar enkele van de bovengenoemde elementen te vinden zijn.

\section{David Hume en de internationale samenleving}

De hedendaagse aandacht voor Hume's werk is vooral gericht op zijn algemene filosofie, terwijl zijn tijdgenoten veel meer interesse hadden voor zijn politieke opvattingen. Hume was zeer geïnteresseerd in de internationale politiek. Hij heeft diverse diplomatieke missies uitgevoerd en een ambassadepost bekleed. Ook was hij kortstondig bewindsman op het Britse ministerie van buitenlandse zaken. Voor IB-theoretici is zijn meest bekende werk een essay met een positief oordeel over de machtsbalans. Op basis daarvan wordt hij meestal als een realist beschouwd, maar een integrale analyse van zijn ideeën over internationale betrekkingen geeft een ander beeld.

Hume's buitenlandse politiek begint bij zijn mensbeeld, waarin een prominente rol is weggelegd voor de individuele, emotionele verbondenheid aan de natie, die ook wordt aangeduid met de termen 'staat' of 'land'. De staat is de belangrijkste speler in de buitenlandse politiek. In tegenstelling tot de realisten ziet Hume de internationale orde als een rudimentaire samenleving van nationale staten. $\mathrm{Zij}$ besturen hun onderlinge betrekkingen deels op basis van het internationaal recht ('laws of nations'), waarbinnen plek is voor het idee van rechtvaardigheid, met name als het gaat om oorlogsvoering. Dit geeft de invloed van Hugo de Groot weer op het denken van Hume. De laatste prijst oorlog niet snel aan als instrument van buitenlandse politiek, maar ziet zelfverdediging en het behoud van de machtsbalans wel als legitieme redenen ervoor. Hume verwerpt het imperi- 
alisme, met name in het debat over de Amerikaanse onafhankelijkheid. Hij ziet ook geen economische reden om de koloniën te behouden. Hoewel hij het minder systematisch uitwerkt dan zijn vriend Smith, is ook Hume een fervent aanhanger van vrijhandel en polemiseert hij veel en graag tegen het mercantilisme van zijn tijd. Maar anders dan de meeste 19e-eeuwse liberalen legt hij geen relatie tussen handel en vrede.

Alles afwegend levert dit een beeld op van Hume als Grotiaan en aanhanger van de natuurrechtelijke traditie van de rechtvaardige oorlog, hetgeen lijnrecht ingaat tegen het oordeel van een aantal vooraanstaande IB academici, zoals Wight, Nye, Waltz en Walzer.

\section{Adam Smith, Oorlog en Handel}

Adam Smith is een aanzienlijk veelzijdiger denker dan zijn hedendaagse imago als econoom en vrijhandelaar doet vermoeden. Hoewel het direct een succesvol boek was, publiceerde hij The Wealth of Nations pas laat in zijn leven. Daarvoor was hij bekend vanwege zijn moraalfilosofie en rechtswetenschappelijke opvattingen. Net als Hume ziet Smith de natie als een positief te waarderen verband, dat voor het individu een bron van trots en eer is. In tegenstelling tot zijn Stö̈cijnse inspiratiebronnen ziet Smith niets in een wereldburgerschap en is hij zeker niet kosmopolitisch georiënteerd. Hij heeft minder fiducie in internationaal recht dan Hume, hoewel hij onderkent dat er werkende regels en gebruiken zijn in de internationale arena. Hij besluit zijn Theory of Moral Sentiments dan ook met een expliciete blijk van waardering voor De Iure Belli ac Pacis, het meesterwerk van De Groot.

Opvallend is dat Smith zoiets als een Europese economie en cultuurgemeenschap ontwaart, waaraan hij overigens geen politieke conclusies verbindt. Ondanks alle leed en verspilling die ermee gepaard gaat, is oorlog volgens hem een normaal, vaak ook legitiem verschijnsel in de internationale betrekkingen. Smith schrijft uitgebreid over de organisatie van de nationale defensie, mede onder invloed van het Schotse debat over de wenselijkheid een eigen permanent leger op te richten. Smith kiest voor een degelijk leger in plaats van milities, niet in de laatste plaats omdat dit het mogelijk maakt om permanente buitenlandse handelsposten op te rich- 
ten en te verdedigen. Vanzelfsprekend is Smith een vrijhandelaar, maar hij onderscheidt wel diverse gronden om volledige vrije handel te beperken, bijvoorbeeld als de nationale defensie in het geding is. Defensie is belangrijker dan welvaart, zegt hij. Dat de wereld ooit door vrijhandel zal worden gekenmerkt acht hij een utopie. Net als Hume ziet hij geen verband tussen vrede en handel en ook Smith is een fervent verdediger van de Amerikaanse onafhankelijkheid.

Naar Smith wordt slechts sporadisch verwezen in de IB literatuur, met uitzondering van referenties aan zijn handelspolitieke standpunt en een artikel van de hand van Andrew Walter. Veel IB-academici denken ten onrechte dat Smith een Kantiaanse kosmopoliet was, die als grondlegger kan worden gezien van het 20e eeuwse Wilsoniaanse liberaal-internationalisme. Dit is onjuist. Smith kan echter ook niet als realist worden gezien, zoals Walters suggereert, want hij denkt niet Hobbesiaans en geeft geen Machiavellistische beleidsaanbevelingen. Ook Smith kan beter in het Grotiaanse kamp worden geplaatst.

\section{Ludwig von Mises, Kapitalisme en Vrede}

Mises is één van de belangrijkste klassiek liberalen van de 20e eeuw, door zijn oeuvre en zijn invloed als docent, zowel in Oostenrijk als de Verenigde Staten. Hij benadrukt dat internationale arbeidsdeling uiteindelijk tot vrede leidt. Dit sterk economische, schijnbaar Kantiaanse gezichtspunt doet echter niets af aan het belang dat ook Mises hecht aan de nationale staat. Net als voor Hume en Smith bestaat zijn ideale wereldorde uit een samenleving van nationale staten. Als schrijver uit het voormalig Oostenrijks-Hongaarse rijk heeft hij veel oog voor de kwalijke gevolgen van het nationalisme. Hij pleit voor bijna onbeperkte zelfbeschikking, maar keurt ieder pleidooi af voor de revolutionaire verandering van de wereldorde. Mises wijst voortdurend op de zwakke punten van de Volkenbond, welke volgens hem economisch nationalisme in de hand werkt en de ongelijke positie van de koloniën voor de eeuwigheid vastlegt. Hij keert zich tegen Wilson en de ideeën van andere liberaal internationalisten, zoals Norman Angell. Mises denkt dat internationale organisaties oorlog niet kunnen voorkomen en soms zelfs stimuleren, omdat ze belemmerend werken bij 
het tot stand brengen van de volledige vrijheid van handel en immigratie. Internationaal recht is onvolkomen, maar wel belangrijk. Europese integratie kan volgens hem helpen om oorlogen te voorkomen en Mises is een tijdje zeer actief in de Pan-Europese beweging. Hij ziet niets in ontwikkelingshulp, omdat hij er geen resultaat van verwacht en het ook een expliciete steunbetuiging is voor het slechte, socialistische beleid van diverse heersers in de voormalige koloniën.

Mises' leven is sterk beïnvloed door de twee wereldoorlogen in de twintigste eeuw. Hij schrijft zelfs twee boeken die geheel aan de internationale politiek gewijd zijn. Net als Hume en Smith ziet hij een verband tussen de menselijke natuur en oorlog en denkt hij dat taalverschillen eeuwige bronnen van conflict zijn. Mises probeert via economische analyses aan te tonen dat het mogelijk is om het aantal oorlogen te verminderen of uit te bannen. Daarvoor is het nodig dat mensen inzien dat hun belangen het best worden gediend door de volledige vrijheid van handel en migratie.

Mises wijkt met zijn standpunten over internationale betrekkingen deels af van Hume en Smith. Naast het verschil in actuele omstandigheden, blijkt hij zich vooral te beroepen op 19e-eeuwse denkers als Bentham, Ricardo, Bastiat, Cobden en andere leden van de Manchester School. Mises denkt dat hij zich ook baseert op Smith en Hume, maar interpreteert hen foutief, overigens net zoals Bentham en Cobden dat vóór hem deden. Hoewel een Engelse School classificatie in het geval van Mises moeilijker is dan bij Hume en Smith, moet ook hij, ondanks enkele Kantiaanse trekjes, per saldo tot het Grotiaanse kamp worden gerekend.

\section{Friedrich Hayek, Internationale Orde en Federalisme}

Hayek was de belangrijkste leerling van Mises en is waarschijnlijk de meest toonaangevende klassiek liberaal van de 20e eeuw. Ook voor hem is de natie een belangrijke bron van individuele loyaliteit en maatschappelijke organisatie. Hayek heeft waardering voor patriottisme, maar wijst iedere vorm van nationalisme sterk af. Hij legt een rechtstreeks verband tussen socialisme, nationalisme en imperialisme. Oorlog is voor hem onlosmakelijk verbonden met de internationale politiek en net als Smith en Hume stelt hij dat oorlog soms nodig is. Zonder veiligheid kan er geen indivi- 
duele vrijheid zijn. Later in zijn leven schrijft Hayek diverse stukken waarin hij militair ingrijpen verdedigt (Iran, Falklands) en het belang van de machtsbalans benadrukt. Hayek's ideeën over internationale betrekkingen worden gekenmerkt door een voorkeur voor federalisering van regio's waar een 'gewone' samenleving van nationale staten niet ontstaat, of niet is te handhaven. Tussen de jaren dertig en vijftig gaat het dan om het Europese continent, later pleit hij voor de federalisering van Jeruzalem. Maar een wereldfederatie gaat hem te ver, omdat hij vreest dat deze vooral een bedreiging van de individuele vrijheid met zich mee zou brengen.

De Volkenbond, de Verenigde Naties en de meeste andere internationale organisaties krijgen weinig waardering van Hayek, omdat ze te veel taken hebben en te constructivistisch zijn, bijvoorbeeld door het begrip mensenrechten op te rekken met sociale en economische rechten, bovenop de door hem zeer gewaardeerde klassieke burger- en politieke rechten. Desondanks is Hayek tegen de boycot van Zuid-Afrika, hoewel hij geen voorstander is van apartheid. Ook verdedigt hij het regime van Pinochet in Chili onder verwijzing naar het goede economische beleid. Hayek steunt dekolonisatie, maar ziet het wanbeleid van de socialistische heersers in de nieuwe staten met lede ogen aan. Niet ontwikkelingshulp, maar vrijhandel is volgens hem belangrijk voor de ontwikkeling van de arme landen. Later in zijn leven staat hij de denationalisatie van alle munten voor en is hij verklaard tegenstander van de Europese Economische en Monetaire Unie. Hayek geeft weinig prijs over de bronnen voor zijn ideeën over internationale politiek, op Acton na. Hij lijkt in dit kader niet bijzonder beïnvloed door de Manchester School, noch door Tocqueville. Hayek mengt zich soms in het IB-debat in de jaren dertig en keert zich daarin tegen Angell en vooral tegen de Marxist en realist Carr. Vergeleken met Mises heeft hij meer op met het realisme en keert hij zich sterker tegen door hem als utopisch afgedane opvattingen over een nieuwe en betere wereldorde. Uiteindelijk is ook Hayek een Grotiaan.

\section{Liberalisme en de theorieën van internationale betrekkingen}

De bevindingen van de voorgaande vier hoofdstukken geven aan dat het klassieke liberalisme een eigen kijk heeft op internationale betrekkingen. 
Het is nu mogelijk om de hoofdlijnen van een klassiek liberale theorie van IB te schetsen. Deze normatieve theorie begint bij de verhouding tussen individu, natie en staat. De natie vormt een integraal deel van de individuele persoonlijkheid. Maar nationalisme is uit den boze. De staat is de belangrijkste speler op het wereldpolitieke toneel, die samen met andere staten een internationale samenleving in stand dient te houden. Bovenstatelijke samenwerking in de vorm van federaties is pas wenselijk zodra is gebleken dat in een bepaalde regio geen normaal statenstelsel kan ontstaan.

De klassiek liberale theorie van IB omvat de Grotiaanse ideeën over internationale orde, zoals de waarde van de machtsbalans, de positieve rol van de rechtvaardige oorlog en het internationale recht. Dit laatste overigens zolang het beperkt blijft tot de vertaling van het natuurrecht in internationale betrekkingen, positief rechtelijke claims zijn uit den boze. De staat dient slechts een minimaal aantal taken te vervullen. Daarbij dient de rol van internationale gouvernementele organisaties verminderd te worden. Voor imperialisme is geen plek. Ten aanzien van de Europese integratie werpt de klassiek liberale theorie van IB geen bezwaren op tegen de vorming van een federatie, maar daar zijn wel strikte voorwaarden aan verbonden, zoals instemming door de grote meerderheid van de bevolking en limitering van de centrale taken. De huidige Europese Unie komt niet in de buurt van het klassiek liberale ideaal, daarvoor zou het grootste deel van het huidige takenpakket moeten worden afgestoten en tegelijk voortgang moeten worden gemaakt op het terrein van buitenlandse politieke en defensie. In tegenstelling tot veel andere liberalen in IB ziet de klassiek liberale IB-theorie geen relatie tussen vrijhandel en vrede. Publieke ontwikkelingshulp moet worden gestopt. Alleen de ongehinderde werking van het kapitalisme kan onderontwikkelde landen verder helpen.

De klassiek liberale IB-theorie verschilt sterk van de verschillende andere vormen van liberalisme in de theorie van internationale betrekkingen. Dat wordt duidelijk uit de vergelijking met het liberaal internationalisme, liberaal institutionalisme, neoliberalisme en 'embedded' liberalisme. In dit licht is het niet verrassend dat het liberalisme in diverse IB-tekstboeken onvolledig wordt behandeld en er ook sprake is van een vertekende weergave van het begrip klassiek liberalisme in andere debatten in de IB-theorie, zoals over de democratische, of liberale, vrede. De analyse wijst er voorts op dat er in IB een flink aantal vormen van liberalisme de ronde doen, vaak 
geïntroduceerd door vooraanstaande academici, welke als verzonnen en nietszeggend terzijde moeten worden geschoven bij gebrek aan fatsoenlijke fundering in de politieke filosofie.

\section{Conclusie en mogelijkheden voor nader onderzoek}

Het is duidelijk dat IB-theoretici hun idee van het liberalisme grondig dienen te herzien. $\mathrm{Zij}$ zijn zich onvoldoende bewust van het klassieke liberalisme als een coherente traditie, hetgeen overigens als additioneel bewijs voor de onnatuurlijke scheiding tussen IB en politieke filosofie moet worden gezien. IB-academici hebben de klassiek liberale traditie schromelijk verwaarloosd, de ideeën van de meest prominente denkers ervan verkeerd geïnterpreteerd en mede daardoor geven zij de liberale ideeën verkeerd of onvolledig weer.

De synthese van de denkbeelden van Hume, Smith, Mises en Hayek maakt duidelijk dat het klassieke liberalisme een eigen plek in de IB-theorie verdient. Er is een groot verschil met andere varianten van het liberalisme in de IB, gebaseerd als deze zijn op het denken van Kant, Bentham, Cobden en vaak ook Mill. Klassiek liberalen denken dat menselijke conflicten niet zijn uit te bannen en daardoor oorlog ook niet. Het gaat erom het uitbreken van oorlog te verminderen en de uitwassen te kanaliseren met behulp van het internationale recht. Voor planning van internationale orde door internationale gouvernementele organisaties schiet de menselijke capaciteit tekort. De emotionele band tussen individu en staat maakt het streven naar een wereldregering zinloos en zou overigens ook een groot gevaar voor de individuele vrijheid betekenen.

Voor academici die werken binnen de Engelse School geeft de toevoeging van het klassieke liberalisme aan de Grotiaanse traditie reden om meer aandacht te schenken aan de internationale rol van het kapitalisme en aan Europese integratie. Ook dient het denken over het individu te worden herzien, omdat dit tot nu toe vooral plaats had binnen de Kantiaanse traditie. Daarbij is het bestaan van een Grotiaanse traditie in de ideeëngeschiedenis bevestigd, hetgeen ingaat tegen recente claims dat IB-tradities verzonnen zijn. 
Natuurlijk is er nog voldoende stof voor nader onderzoek. Bijvoorbeeld de analyse van het werk van een groter antal klassiek liberale denkers en de nadere uitwerking en verfijning van de klassiek liberale theorie van IB. Daarnaast is het noodzakelijk om de ideeën over internationale betrekkingen van andere denkers te bestuderen ten einde het kennishiaat tussen IB en politieke filosofie op te vullen en meer lading te geven aan de tradities van de Engelse School. Een belangrijk deel van de liberale puzzel is echter opgelost in dit proefschrift. 


\section{Curriculum Vitae}

Edwin René van de Haar werd geboren op 28 juli 1971 te Zeist, waar hij in 1989 het diploma in het Hoger Algemeen Voortgezet Onderwijs verwierf aan Rijksscholengemeenschap Schoonoord. $\mathrm{Na}$ een jaar op het Centraal Instituut voor de Opleiding tot Sportinstructeur (CIOS) in Sittard stapte hij over naar de lerarenopleiding geschiedenis aan de Faculteit Educatieve Opleidingen van de Hogeschool Midden-Nederland in Utrecht. Met de daar behaalde propedeuse ging hij in 1991 naar de Universiteit Leiden, waar hij in 1996 afstudeerde in de politicologie. Van de Haar vervolgde zijn studie aan de London School of Economics and Political Science en werd daar in 1997 Master of Science (Econ) in International Relations. In 2001 verwierf hij, na avondstudie, een propedeuse in de rechtsgeleerdheid aan de Universiteit Leiden.

Tussen 1997 en 1999 was Van de Haar werkzaam als junior public affairs consultant bij Praaning Meines Consultancy Group in Den Haag. Daarna werkte hij op het ministerie van Economische Zaken, eerst binnen het Directoraat-Generaal Industrie \& Diensten, vervolgens als beleidsmedewerker handelspolitiek bij het Directoraat-Generaal voor de Buitenlandse Economische Betrekkingen. Tussen 2001 tot 2003 was hij senior public affairs consultant en manager van de practice group Politiek-Maatschappelijk \& Beleid bij communicatieadviesbureau Bennis Porter Novelli in Amstelveen, om vervolgens terug te keren naar de publieke sector, als public affairs adviseur en woordvoerder van de Onafhankelijke Post en Telecommunicatie Autoriteit (OPTA).

Sinds augustus 2006 woont Van de Haar met vrouw en zoon in de Filipijnse hoofdstad Manilla, waar zijn echtgenote Ambassaderaad en plaatsvervangend chef de poste is van Harer Majesteits ambassade. Hijzelf is docent internationale betrekkingen aan het European Studies Program binnen de School of Social Sciences van Ateneo de Manila University en daarnaast free lance journalist, voornamelijk voor het weekblad Elsevier. 
